\title{
Health, profession and behavior : an investigation into the health educational aspects of the work of elementary schoolteachers, community nurses and general practitioners in the Netherlands
}

Citation for published version (APA):

Adriaanse, H. P. (1988). Health, profession and behavior : an investigation into the health educational aspects of the work of elementary schoolteachers, community nurses and general practitioners in the Netherlands. [Doctoral Thesis, Maastricht University]. Rijksuniversiteit Limburg.

https://doi.org/10.26481/dis.19880609ha

Document status and date:

Published: 01/01/1988

DOI:

10.26481/dis.19880609ha

Document Version:

Publisher's PDF, also known as Version of record

Please check the document version of this publication:

- A submitted manuscript is the version of the article upon submission and before peer-review. There can be important differences between the submitted version and the official published version of record. People interested in the research are advised to contact the author for the final version of the publication, or visit the $\mathrm{DOI}$ to the publisher's website.

- The final author version and the galley proof are versions of the publication after peer review.

- The final published version features the final layout of the paper including the volume, issue and page numbers.

Link to publication

\footnotetext{
General rights rights.

- You may freely distribute the URL identifying the publication in the public portal. please follow below link for the End User Agreement:

www.umlib.nl/taverne-license

Take down policy

If you believe that this document breaches copyright please contact us at:

repository@maastrichtuniversity.nl

providing details and we will investigate your claim.
}

Copyright and moral rights for the publications made accessible in the public portal are retained by the authors and/or other copyright owners and it is a condition of accessing publications that users recognise and abide by the legal requirements associated with these

- Users may download and print one copy of any publication from the public portal for the purpose of private study or research.

- You may not further distribute the material or use it for any profit-making activity or commercial gain

If the publication is distributed under the terms of Article $25 \mathrm{fa}$ of the Dutch Copyright Act, indicated by the "Taverne" license above,

Download date: 26 Apr. 2023 


\section{HEALTH, PROFESSION AND BEHAVIOR}

An investigation into the health educational aspects of the work of elementary schoolteachers, community nurses and general practitioners in the Netherlands

\section{PROEFSCHRIFT}

ter verkrijging van de graad van doctor aan de Rijksuniversiteit Limburg te Maastricht, op gezag van de

\section{Rector Magnificus Prof.dr.F.I.M.Bonke}

volgens het besluit van het College van Dekanen, in het openbaar te verdedigen op donderdag, 9 juni 1988 om 16.00 uur

door

Hans Peter Adrlaanse

geboren op 19 februari 1946 te Amsterdam. 
Promotores: Prot.dr. G.J.Kok

Prof.dr. S.K.Simonds, Hoogleraar Gezondheidsvoorlichting en -Opvoeding, University of Michigan, Ann Arbor, USA

Beoordellingscommissia:

Voorzitter. Prot.dr. H.Philipsen

Leden: Prof.dr.L.W.Green, Hoogleraar Gezondheidswoorlichting en -Opvoeding, Director Center for Health Promotion Research and Development, University of Texas, Houston, USA (thans: Vice-President Kaiser Family Foundation, Menlo Park CA, USA)

Prof.dir.A.Knottnerus

Prof.dr.V.Strecher, Hoogleraar Gezondheidsvoorlichting en -Opvoeding, University of North Carolina, Chapel Hill, USA

Dr.A.Ph.Visser

Copyright $\Theta$ by Hans Adriaanse

ISBN 90-9002285-6

No part of this book may be reproduced in any form by print, photoprint, microfilm or any other means without the prior written permission from the authors.

Tekstvenwerking: Hélène Vermeer, Vakgroep Gezondheidswoorlichting en -Opvoeding. Faculteit Gezondheidswetenschappen, Rijksuniversiteit Limburg, Maastricht

Druk: Ben Meerstad, Drukkerij, Rijksuniversitelt Limburg, Maastricht

Grafische vormgeving: G. van Rooy, Audio Visuele Dlenst, Rijksuniversiteit Limburg, Maastricht, I.s.m. Bureau van de Manakker, Maastricht

Financial support by Inpharzam Nederland BV Almere for the publication of this thesis is gratefully acknowledged.

Trefwoorden: health behavior, health education, teachers, physicians, nurses. 


\section{Table of Contents}

Acknowledgements

Chapter 1. Introduction

Preface

1.1

Health education

1.2

Schoolteachers, community nurses and general

practitioners as key health professionals

Health education in elementary schools, community nursing and general practice in the Netherlands

Conceptualization of health education in:

General practice

Health behavior

Summary

\section{LITERATURE REVIEW}

Chapter 2. Health education

Community nurses' conceptualization of health education

Role expectations, role performance 34

Role expectations, role performance 38

2.6

2.7

Discussion

Conclusions 
$3.1 \quad$ Conceptualization 54

3.2 Three approaches of health behavior 56

3.2.1 Atomistic conception of health behavior 56

3.2.2 Additive conception of health behavior 56

3.2.3 Scaling approach to health behavior 58

3.3 Research into key health professionals" health behavior 60

3.3.1 Health behavior in schoolteachers 60

3.3.2 Health behavior in community nurses 61

3.3.3 Health behavior in general practitioners 62

3.4 Discussion 66

3.5 Conclusion 66

3.6 Summary 66

$\begin{array}{lll}\text { Chapter 4. Exemplary role } & 73\end{array}$

Introduction $\quad 74$

$\begin{array}{lll}4.1 & \text { Conceptualization } & 74\end{array}$

4.2 Exemplary role of key health professionals 77

4.2.1 Schoolteachers' exemplary role with regard to health 78

4.2.2 Community nurses' exemplary role with regard to health 79

4.2.3 General practitioners' exemplary role with regard to health 81

4.3 Discussion 83

4.4 Conclusions 84

$\begin{array}{lll}4.5 & \text { Summary } & 84\end{array}$

$\begin{array}{ll}\text { Chapter 5. Mothod and materlals } & 91\end{array}$

$\begin{array}{lll}5.1 & \text { Framework of the study } & 92\end{array}$

5.2 Questionnaires 93

$\begin{array}{lll}5.3 & \text { Samples } & 94\end{array}$

$\begin{array}{lll}\text { 5.3.1 Schoolteachers } & 94\end{array}$

$\begin{array}{lll}\text { 5.3.2 Community nurses } & 94\end{array}$

$\begin{array}{lll}5.3 .3 & \text { General practitioners } & 95\end{array}$

$\begin{array}{lll}5.3 .4 & \text { Non-response } & 95\end{array}$

5.3.5 Characteristics of the sample 95

$\begin{array}{lll}5.4 & \text { Measurement by personal interview } & 97\end{array}$

$5.5 \quad$ Variables 98

5.6 Discussion 98

$\begin{array}{lll}\mathbf{5} .7 & \text { Summary } & 98\end{array}$ 


\section{RESULTS}

Chapter 6. Health education: results

\section{1}

Introduction: development of health education competencies

102

6.2

Operationalization of health education

6.3

6.3.1

Results

104

Health education perception in the actual situation

Health education activities and collaboration

6.4

Discussion

6.4 .1

Method

Comparison with previous research

Chapter 7. Health behavlor: results

by Hans Adriaanse and Tjaard Imbos, Department of Statistics and Medical Information, University of Limburg 
8.1 Introduction 152

8.2 Operationalization of the exemplary role 152

8.3 Perception of the exemplary role 155

8.4 Discussion 155

8.4.1 Mathod 155

$\begin{array}{lll}\text { 8.4.2 Results } & 156\end{array}$

$\begin{array}{lll}\text { 8.4.3 Previous results } & 156\end{array}$

$8.5 \quad$ Conclusions 158

$\begin{array}{lll}8.6 & \text { Summary } & 158\end{array}$

Chapter 9. Assoclations of health behavlor with exemplary role recognition and perception of health education

9.1 Introduction 162

$\begin{array}{lll}9.2 & \text { Bivariate associations } & 163\end{array}$

9.2.1 Health behavior and exemplary role 163

9.2.2 Health behavior and health education in the actual situation 164

9.2.3 Health behavior and health education in the desired situation 165

9.2.4 Exemplary role and health education in the actual situation 166

9.2.5 Exemplary role and health education in the desired situation 167

9.2.6 Health education as perceived in the actual 168

9.3 Multivariate relationships between health behavior,

9.3.1 Correlations, inter- and partial 169

9.3.2 Determinants of health education perception: regression analysis 171

$\begin{array}{lll}\text { 9.3.3 Differences between professional groups: discriminant analysis } & 172\end{array}$

$\begin{array}{lll}9.4 & \text { Discussion } & 174\end{array}$

$\begin{array}{lll}9.5 & \text { Conclusions } & 176\end{array}$

$\begin{array}{lll}9.6 & \text { Summary } & 177\end{array}$

Chapter 10. General dliscussion; concluding remarks $\quad 179$

$10.1 \quad$ Brief review of the intended study 180

10.2 Realization of the project 180

$\begin{array}{lll}10.3 & \text { Results } & 180\end{array}$

10.4 Limitations 182

10.5 Implications of the study for: $\quad 182$

$\begin{array}{lll}\text { 10.5.1 mathods } & 182\end{array}$

$\begin{array}{lll}10.5 .2 & \text { theory } & 183\end{array}$

10.5.3 policy 184

$\begin{array}{lll}\text { 10.5.4 professional preparation } & 185\end{array}$

$\begin{array}{lll}10.6 & \text { Further research } & 186\end{array}$

Summarles $\quad 189$

$\begin{array}{ll}\text { Currlculum vitae } & 198\end{array}$ 


\section{Acknowledgement}

The research reported here originated from the work carried out since 1981 under the guidance of professors Hans Philipsen and Maria J.Drop, then both at the Department of Medical Sociology of the School of Medicine in Maastricht. II thank them for the many learning opportunities they gave me in their domain. Professor Wilma Rouwenhorst, the "grand old lady" of Dutch health education has been a creative persecutor of my first attempts to get the study started. Since January 1986, the supervision of the project was done by my promotors, professor Gerjo Kok, whom I am grateful for his systematic and clear way of commenting on my many drafts, and by professor Scott K.Simonds, advisor to our Department of Health Education in the period of 1979 to 1986. He has visited the Department in Maastricht regularly in those years. I thank him especially because, although mostly at great distance, he has had a decisive influence on my development. Scott Simonds has taught me many things about health education that can be found in this report. In addition and most importantly, Simonds has been a role model for me. If I sometimes act as a civilized academic, I am much indebted to him.

As colleagues I have been working with closely over the years, with whom I had the opportunity to share many educational experiences, I want to mention here Ruud Halfens from the Department of Nursing Science, Tjaard Imbos from the Department of Statistics and Medical Information and Jan van Reek from the Department of Medical Sociology, all at the University of Limburg in Maastricht.

Quite naturally, I am also grateful to the Board of the University of Limburg, which, after my four years of half-time administrative endeavors, in 1986 gave me a sabbatical leave during which I could focus on the research reported here. I explicitly thank the Information Center MEMIC, whose Marlene Kruyen, Louis Ploumen and Gregor Franssen always have been supportive in a very efficient way, designing questionnaires, analyzing, retrieving or plotting graphs.

I thank as well the members of my committee, professors Hans Philipsen (chair), André Knottnerus and Adriaan Ph. Visser, all at the University of Limburg, Victor Strecher from the School of Public Health at Chapel Hill, North Carolina, and Larry Green from the Center for Research and Development of Health Promotion at Houston (present address: Henry J. Kaiser Family Foundation at Menlo Park, California) for their constructive comments on the linal draft.

Of utmost importance to me has been the indestructible optimism with which mrs. Hélène Vermeer, secretary of the Department of Health Education, University of Limburg, has coped with the development of the manuscript: I thank her for the great precision and speed with which she managed to do all the work needed to produce this dissertation amidst the maelstrom of a 27-people department.

Maastricht, May' 1 st $_{n} 1988$

Hans Adriaanse 


\section{Chapter 1. Introduction}

\section{Preface}

1.1 Health education

1.2 Schoolteachers, community nurses and general practitioners as key health professionals

1.3 Health education in elementary schools, community nursing and general practice in the Netherlands

1.4 Conceptualization of health education in:

1.4.1 Elementary education

1.4.2 Community nursing

1.4.3 General practice

1.5 Health behavior

1.6 Exemplary role of key health professionals

1.7 Central questions

1.8 Summary 


\section{Preface}

The purpose of this study is to examine health education in the work of schoolteachers, community nurses and general practitioners, their health behavior and their perception of an eventual exemplary role and to analyse the relationships between these variables. Schoolteachers, community nurses and general practitioners have been chosen because these professions are at the core of day-to-day health education delivery, in the primary health care and the school system. That is why they are called "key health professionals". Health has become increasingly important in Dutch elementary education, while education is being seen more and more as a generic component of primary health care.

Essential for protessionally delivered health education is aiming at voluntary behavior change through a teaching-learning process. Whereas teaching and learning of, e.g. chemistry or astronomy might well be done without involving ourselves as persons, health education is hardly possible without the involvement of personal behavior, personal values and choices. These concern knowledge, attitudes and skills related and/ or directed to health. That is why key health professionals' perceptions of their health educational tasks, of their health behavior and of an eventual exemplary role with regard to their target group's health is subject to analysis in this report.

The results of the study are reported as follows: after an introductory chapter, the literature concerning the three central concepts in the study, i.e. health education, health behavior and exemplary role, is reviewed. Then the methods of the empiricall part of the report is presented. The results of the nationwide survey carried out among key health professionals are presented in the next chapters first through univariate analysis (chapters 6 to 8), then through multivariate analysis (chapter 9) of the data.

Operational definitions of the central concepts of the study are made on the basis of the literature reviews and will be given after their presentation. However, to help the reader understand what the essence of the study is, it seemed advisable to anticipate at this point and mention these definitions of "health education", "health behavior", and "exemplary role" for the purposes of the study at the front end of the report.

Health education, in accordance with Green "Kreuter, Deeds \& Partridge (1980), is conceived as "any designed combination of methods to facilitate voluntary change of behavior conducive to health".

Health behavior will be defined as: any of a selected set of actions related to health and/ or directed towards maintaining health.

Exemplary role is seen as professionals' perception of his or her personal health behavior and lifestyle with regard to the impact thereof on their target-groups as well as the population at large.

Our findings are discussed in chapters 6 to 9 , whille conclusions from the investigation are formulated in chapter 10. A summary in English, Dutch and Esperanto is given at the end of this thesis.

In this introductory chapter an overview is given of what will be presented in this report. Before going into the conceptualization of health education by school teachers, 
community nurses and general practitioners in the Netherlands, the concept of health education itself is discussed. Then the rolle of teachers, nurses, and general practitioners in health education is introduced. Next the nature of health behavior and the role of key health professionals personal health behavior with regard to the public at large is briefly sketched. A paragraph linking the scope and purpose of this investigation to the development of a health policy in this country concludes the introduction.

\subsection{Health education}

Both "health" and "education" are concepts with rich backgrounds, conceived differently by many authors. Their combination into the relatively new concept of health education needs clarification. Health education theoreticians have defined health education in various ways, wherein nevertheless a common core is distinguilshable. Older, but very influential definitions of health education are Derryberry"s and Stevart's: "Health education is concerned with improved health attitudes and behavior in the general public. Accomplishment of these goals requires careful and thorough consideration of the present knowledge, attitudes, goals, perceptions, social status, power structure, cultural traditions and other aspects of whatever public to be reached" (Derryberry, 1960, in Simonds, 1982), and "The essence of health education is its scientific concern with the role of human behavior, individual and societal, in the natural history of health and disease considered from the special point of view of the determinants of change in such behavior with an operational focus on those planned influence attempts directed towards maintenance, reinforcement of modification of behavior in the extent to which this may demonstrably affect curative, rehabilitative and disease preventive processes and the promotion of health" (Steuart, 1965, p.6). Another, still valuable, definition was given by Baric: "Informal health education is considered to be concerned with internalization of health norms by an individual, essentially by means of primary socialization, resulting in desired health-related behavior. Formal health education is concerned with transmitting knowledge about health and disease as a part of secondary socialization, resulting in desired health-directed behavior" (Baric, 1972, p.22).

In two more recent definitions from American health education theoreticlans health education was described in two ways: (Operational definition) "Health education is a deliberately planned, structured learning opportunity about health that occurs in a setting at a given point in time and involves an interaction between an educator and learner", (Process definition) "Health education is a change in health-related behavior in individuals or groups that leads to an improvement in health status for those individuals or groups" (Bates and Winder, 1984, p.226).

In their authorative manual on health education planning Green et al give the following definition of health education: "Any designed combination of methods to facilitate voluntary adaptations of behavior conducive to health" (Green ell al., 1980, p.7).

The World Health Organization defines health education as "consciously constructed opportunities for learning which are designed to facilitate changes in behavior towards a pre-determined goal". The WHO recently adopted health promotion as overarching term: "Health promotion is the process of enabling individuals and communities to increase control over the determinants of health and thereby improve their health". Health 
promotion's ultimate goal is "to ensure that the total environment is more conducive to health". Health education is considered to be a crucial tool for health promotion (Nutbeam, 1986, p.110).

The Dutch theoreticians in the field of health education have been influenced by the developments in health education theory in the Anglosaxon world. Founding mother of health education in the Netherlands, Wilhelmina Rouwenhorst, has pointed out that by using the term health education sometimes an ideology or a philosophy is implied, or an application of a scientific insight. Health education can also be used in the sense of a dimension of health care or an instrument to deliver health care. For scientific purposes she defines health education as "a health education intervention which is that component of health care that tries, for those health problems related to either individual or collective human behavior, in collaboration with the client-system, to develop health promoting behaviors in order to solve the health problems inasiar as they are within human responsibility. Health education interventions are carried out as a participation-acquiring function, in addition and in relation to other functions (of the health care system (HA)), in a scientifically and socially responsible way, respecting the freedom of personal choice and own responsibility of the addressed client-system, by offering systematically and persuasively, information, knowledge and behavioral options, thus enabling the clientsystem to make choices and decisions, to develop and maintain certain behaviors" (Rouwenhorst, 1981, p.145).

In an analysis of 26 policy documents on which health policy in the Netherlands was based during the last seven years, the term health education was found to be used inconsistently. On the one hand health education was used more and more frequently as an important element of a balanced health policy. On the other hand, health education is sometimes completely omitted in crucial stages of policy development lie. in documents regarding first line health care. Moreover, it is observed that many pay lipservice to health education using it as a notion containing of a variety of messages. As health care in the Netherlands is a patchwork quilt, conceptualization and delivery of health education will unavoidably continue to be unclear (Hagendoorn \& Verburg, 1986; Zielhuis, 1985).

in his inaugural speech, Kok delineated health education as follows: "Health education activities are characterized by:

- a focus on those health problems involving personal behavior;

- an analysis of the causation of behavior(s) involved;

- attempts to influence relevant behavior by motivating those concerned to adopt other behavior(s);

- assessment of the attempted changes in order to improve the health education applied" (Kok, 1986).

From these definitions it can be seen, that elements of the common core of health education are at least:

- relationship between health and behavior

- personal choice among behavioral options

- participation by lay people

- systematic change efforts. 
The way health education has been conceptualized more specifically among teachers, nurses and physicians will be outlined in the next paragraphs.

\subsection{School teachers, community nurses, and general practitioners as key health professionals}

Health is being taken care of for an - often underestimated - large part by lay people and only for the rest they are unable to cope with themselves, by professional health workers (Levin, Katz and Holst, 1979; Kickbusch, 1981; Hatch and Kickbusch, 1983). The impact of the three professional groups under study here is a limited influence only, if the many factors that influence the health status of a given population are considered: legislation environment, power division in society, elc. Nevertheless, education and health care no doubt are two important sectors, influential in the shaping and maintenance of the populations" health habits, and thus of their health status. Schoolteachers, community nurses and general practitioners are professionals, working in close contact with their public, who fulfil essential roles in the care for health of their pupils respectively their patients (Egsmose, 1977; Yarrow, 1977). In this process these prolessionals can have a modeling influence. Professionals in education and in primary health care are studied because these professionals can be considered as those shaping the basis for the care for health in their daily activities. This point of view does not imply that other health professionals like surgeons, dentists, physiotherapists, or pharmacists are less important; it does mean that schoolteachers, community nurses and general practitioners have central positions in the earliest possible stage for professionals to be influential on people's health, while other health workers have important roles in other stages of professional involvement in health and even more, in disease.

Even more than in some other countries, there is reason for schoolteachers, community nurses and general practitioners in the Netherlands to be considered as key health professionals. First-line health care is well developed in the Netherlands and has an intensive contact with the public. Community nursing reaches out into every city neighbourhood or rural village and is especially involved in mother-and child care and care for the elderly in the community at all levels of prevention and care. Community nurses and general practitioners together fulfil a central role in first line health care. General practitioners are local physicians to be consulted before a specialist can start any activity. It is important to note here, that the Dutch general practitioner treats approximately $85 \%$ of the health problems he or she is confronted with without referral to any specialist. Implicitly, health education plays a considerable role in the work of the general practitioner. In the Netherlands there are almost as many general practitioners as there are specialists. The Dutch elementary school system is a relatively homogeneous system of high quality education reaching $100 \%$ of the age classes 4 till 12. Summarizing, it can be said that elementary schoolteachers', community nurses' and general practitioners" position in the basis care for health is very important. They are the first professionals involved in matters of lifestyle development and health problems when these arise in the population at large. 


\subsection{Health education in elementary schools, in community nursing and in general practice in the Netherlands}

Health education has always been part and parcel of the work of school teachers, community nurses and general practitioners but is has not always been labelled explicitely. Within elementary education, health education was provided on an incidental basis by teachers themselves in the tramework of other curricular activities and by the Youth School Health services mainly on an individual basis, without any relationship to curricular health educational activities (Teunissen, 1982). A formal basis for health education has been given by the new law on basic education in 1985, integrating health education in the elementary school curriculum. Curriculum development for school health education stated in the seventies (Hegger, 1979; Hansson and Visser, 1984).

Preparation of teachers for health education teaching first started at teacher training colleges (Hegger, 1980).

Within community nursing health education has been a priority ever since the foundation; in 1875 "to acquire participation of the population in the prevention of communicable disease" by then so prevalent, was already mentioned as such (Mertens, 1983). At local, regional and national level health education was integrated in the work of the community nurse and of public health physicians. In 1963, the first Dutch health educator was employed by the National Green Cross Union. Educated both in the Netherlands and in the USA (School of Public Health, Minneapolis), Wilhelmina Rouwenhorst was to become the founding mother of health education in this country. She was involved both in training and in pollicy development (Rouwenhorst, 1977; 1981; 1982). Prolessor Rouwenhorst was in charge of the first academic health education training program that started at the Univarsity of Limburg in 1980 (Simonds, Rouwentiorst, Adriaanse, Damoiseaux, Dubois \& Saan, 1981; Adriaanse \& Rouwenhorst, 1982). The Green Cross organizes virtually all community nursing care dellivery in the country. Thus community nursing has been the first profession in which health education training was systematically integrated.

The community nursing leadership has had a strong influence both on health education policy development and on health education delivery in practice, up to a point of being seen as monopolizing health education (Mertens, 1983). A recent imvestigation into community nurses' health education perception and practice showed that community nursing teams react reluctantly to health promotion activities and selfhelp initiatives. Community nurses are diligent health educators within the helper patient relationship but often do not feel sufficiently trained (Muskens, 1984). Experiments with local health education initiated by National Cross, actually in process, should show whether there is a place for professional local health educators networking with other local health workers (Van Ballon, 1985):

For a physician, health education is part of the work from the moment (s)he swears the oath of Hippocrates (Van der Does, 1981). Participation of physicians in health education is seen as desirable; postgraduate training in health education and social welfare is necessary (Van der Does, 1981). In 1979 the Dutch Royal College of Physicians (KNMG) published a report entitled "Health Promotion" delineating the role of physicians with regard to health education in a rather restricted sense, leaving the core of health 
education to health education specialists or other health workers with special health education training (KNMG, 1979). In recent policy reports of the Ministry of Health the central position of the general practitioner in primary care is frequently stressed (Ministry of Health, 1980-1985). Patient education's identity has been a debated part of physicians" tasks, only recently developing (Dekkers, 1984; De Haes and Schuurman, 1979; Jonkers, 1979: Lamberts, 1981). It is expected that in the operationalization of the targets to be reached by the Health for All by the year 2000 strategy, the position of health education and the role of school teachers, community nurses and especially general practitioners will only be more strongly emphasized (Ministry of Health, 1986).

\subsection{Conceptualization of health education}

\subsubsection{Elementary education}

Already more than a century ago attempts were made to insert health education as an official part into the elementary school curriculum. This was finally realized two years ago. In that period, no clear school health education conception was available in the Netherlands, though attempts to build bases for its development were regularly made. In 1972, a Task Force on elementary school health education defined the goal of health education as to help the individual to do whatever enhances his and others health, and to refrain from whatever might compromise that health (Werkgroep GVO in het Onderwijs, 1972). Inspired by developments in the USA (Sliepcevich, 1964). comprehensive school health education projects were developed in Amsterdam an a local scale and, at the University of Nijmegen's Hoogveld Institute, with a nationwide scope (Hansson \& Visser, 1984; Smits-Van Sonsbeek \& Hegger, 1976). The latter project used the School Health Education Study-concepts of growth and development, interaction and decision-making as a basis for curriculum planning (Hegger, 1979).

Another important report giving impetus to school health education's development in this country was written as a part of the National Plan for Health Education (Dekker, 1982): school health education was seen to be characterized by a comprehensive approach of health by interdisciplinarity, integration of intra- and extracurricular activities, problembased learning and attitudinal education in an open pedagogical climate (Hegger \& Van Hameren, 1981).

In 1985, a Law on Basic Education finally regulated school health education as a curricular topic. Nevertheless the conceptualization of school health education - "Gezondheidseducatie" as it is called in Dutch - to be distinguished from encompassing "Gezondheidsvoorlichting en -Opvoeding", the term used to indicate health education in any other setting, is far from definitive (Wijnsma, 1986).

\subsubsection{Community nursing}

In 1960 health education was officially introduced in the Dutch vocabulary by its translation into "Gezondheidsvoorlichting en -Opvoeding", frequently referred to by abbreviation as "GVO". The National Council for Health defined health education as "informing the public using sound methods, educating the public by skill training and the development of attitudes in order to contribute to the dissemination of behavioral 
patterns and lifestyles; assumed to be directly related to people's physical and mental health, to satety and to adequate use of available social and medical services" (Centralle Raad voor de Volksgezondheid, 1962).

Health education is not considered to be an independent activity within health care: it should be integrated in all health workers' activities. In addition to this integrated health education, its function can be carried out also by means of independent health promotion activities. Notwithstanding this point of view, recently some experiments with professional local health educators were started in some National Cross areas. Internationally, community nursing has been far from being a supporter of a specialist health education model (WHO, 1975), neither has it been in the Netherlands.

Nevertheless, first indications of the experiments with local health educators were encouraging (Van Beilen, 1985).

Local health education aims at tailoring the care offered to the population to its needs by a so-called "upstream" health education policy (Van Beilen \& Faber, 1985). In the light of the $4 \%$ annual volume growth, in effect since 1982, local health education has been widely acclaimed. Though the norm adhered to (one local health educator to 100,000 inhabitants) may indicate an important number of positions (150 for the Netherlands as a whole), the actual share in the growth financewise is limited to $0.2 \%$ over $1988-1992$ (Nationale Krulsvereniging, 1986).

\subsubsection{General Practlce}

Reacting to a proposal for a national structure for health education drafted by the National Committe on Health Education (Kommissie Nationaal Plan GVO; Dekker, 1982), the Dutch Royal College of Physicians formulated its vision on health education based in Steuart's definition (Steuart, 1965). The Royal College adopted a view which restricted physicians' contributions to health education to: - helping to collect base-line data needed for health education planning - reporting of prevalences of (un)healthy behaviors, and of possible causative factors - referring of patients belonging to risk groups to health education activities when adequate, initiating those activities if they are lacking - paying attention to psychological and/or structural barriers within the health care system. The Royal College recommends physicians expressis verbis not to carry out health education activities, unless one is specifically qualified for it. lf not, physicians should leave health education tasks to health education or behavioral specialists (Royal Callege of Physicians, 1979). The Royal College disapproved the term patient education and proposed health counseling as term for physician's task to advise the individual pationt in health matters. Patient education, however, has been seen ever since that debate as regular task of physicians (De Haes \& Schuurman, 1979; Lamberts, 1981).

\subsection{Health behavior}

Health behavior comprises those behaviors of the individual that are intentionally directed to the maintenance or the improvement of his or her health, and behaviors related to health. Life style behaviors based on personal cholces, for instance to go to work by bicycle instead of by car, to refrain from smoking or to use skimmed milk, are part of the health behavior of the individual. Key heialth professionals have more 
knowledge about the effects on health of these behaviors, than the general population. Nevertheless, teachers, nurses and physicians are just human beings, open to (un)healthful social pressures like anybody else. Moreover, they are part of professional subcultures not always sustaining healthful living.

In Chapter 3 an outline will be given of what has been understood by health behavior, what life style aspects it can comprise. Research into health behavior did not result into universally accepted concepts of health behavior. However, the work of the Human Popullation Laboratory in Berkeley, USA, has set a basic model of health bohavior that has had great influence (Berkman \& Breslow, 1983). The focus is on the health behavior of key health professionals. Comprehensive research into their health behavior is scarce, however. Among the three professional groups under study, physicians have got the most attention of health behavior researchers, nurses and teachers far much less. Among the different aspects of life style constituting health behavior, smoking has been researched most frequently, especially among physicians and, to a lesser extent among nurses. Only scattered data were available on professionals" sjeep and resting habits, coffee consumption, preventive medical and dental visits and dietary habits.

In Chapter 3 the conceptualization of health behavior, as well as its operationalization is discussed. The research into key health professionals health behavior is reviewed. The results of our research into health behavior of Dutch teachers, nurses and physicians is presented in Chapter 7. Relationships to the perception of the exemplary role and health educational aspects of their protessional duties will be dealt with in Chapter 9 .

\subsection{Exemplary role of key health professionals}

Health behavior is determined by a multitude of factors, many of which do not influence health directly, e.g. legislation, religion, mass-communications. Many factors within the individual, such as cultural values, knowledge, attitudes, and on the other hand factors external to the individual, such as social and material environment and socio-economic structure in society influence health. Part of the social environment in which health behavior is developed, maintained and, sometimes changed, are significant persons like parents, other adults, wellknown people like sportsmen, film-or television stars, media professionals and health workers (Egsmose, 1977; Yarrow, 1977). These personalities are part of the societal background by which we are surrounded without being aware of it most of the time. Behavior of these personalities can have a modeling influence, depending on their credibility. Their behavior can be seen as being worthwhile imitating. This mimicry can occur without awareness of the process either on the exemplar's side or on the imitator's side. For instance, it can be hypothesized that Michael Jackson's non-smoking influences kids' smoking status. Health workers and teachers are among those potentially modeling personalities. The school teachers, community nurse and general practitioner will be referred to as key health professionals, because they have crucial roles in the earliest possible stages a professional can get involved in the development of his/her pupils' or patients' healthy or unhealthy behavior. Exemplary role in this analysis will be used to indicate the bundle of professionals" perceptions of their own health behavior and life style and its impact. It must be clear, however, that even a smoking physician, who completely denies this role, nevertheless fullils this role in the 
eyes of a big part of the public. The public's expectations with regard to professionals" exemplary role are important but outside the scope of this report.

Recognition and fulfilment of the exemplary role with regard to health behaviour are frequently discussed in the literature of and on the three professions under study; it will be reviewed in chapter 4 . In the Dutch literature references on this topic are scarce. The importance of a possible exemplary role of teachers was stressed by Rouwenthorst citing the ironically modified proverb: "judge me on my words hypothesizes dissonant behavior of a teacher will render his/her health education activities ineffective (Rouwenhorst, 1981). Among community nurses Muskens found a low awareness of their role and its importance. In addition to the necessity of increasing expertise, he considered nurses" credibility to be al stake. However, in the investigation exemplary role recognition was not taken into account. Although its basis is called "proverblal" and "lolkloric", the importance of the exemplary role for community nurses is underlined (Muskens, 1984). With regard to general practitioner's exemplary role fulfilment Lens concluded that Dutch general practitioners largely do not live up to the health advice they provide to patients on smoking, alcohol, exercise, blood pressure control, restrictive use of sall, and weight control. According to Lens, Dutch generall practitioners smoke as much as the general population and more than their socioeconomic class does. Potential andior actual alcoholism is found to a considerable degree. Measured by his Health Behavior Index, only $54 \%$ of the general practitioners live a healthfull life (Lens, 1984). In this context, Wafelbakker (1984) raised the question, whether the smoking status of students should be used as a criterion for admission to training programs in schools of medicine, and faculties of thealth sciences.

To illustrate the lines of reasoning that will be reviewed more extensively in chapters 2 , 3 , and 4 some examples from the literature pertaining to teachers", nurses' and physicians" exemplary role with regard to health behavior are given below. In a position paper of AAPHERD, the exemplary image of school personnel was mentioned, and required to be consistent with current facts on smoking and health (AAPHERD, 1971). Teachers are urged to be aware of their alcohol consumption and related responsibility, considering their influence on the school children (Finn, 1981). Nurses are expected to act as health exemplars at least in their professional lives, with regard to smoking. nutrition, hygiene, but also with regard to their personal lifestyle (Smith" 1984). "Nurses are in a vital position to promote health (.....) by becoming exemplars of good health practices" (Lazenby, 1984, p.8). In numerous articles the exemplary role of physicians is pleaded for: "We need to exemplify what we teach" (Doll, 1983). Physicians should behave consonantly according to key representatives of their profession, with regard to smaking, alcohol consumption, exercise, drug use, stress, nutrition, and weight control (see e.g. Wells, Lewis, Leake \& Ware, 1984; Wechsler, Levine, Idelson, Rohman \& Taylor, 1983).

The frequent arguing for exemplary role recognition and fulfilment with regard to a variety

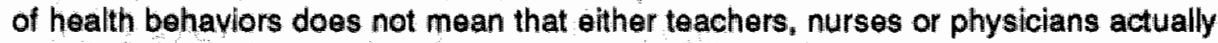
fultil or even recognize that role everywhere, on the contrary. Though the extent to which this is the case will be subject to analysis later on, at this point it is necessary to show some of the counter arguments. Either evidence for the double standard mentality is brought forward "do as I say and not as I do" (Shangold, 1979), or "the alcoholic is the patient drinking more than the physician" (Sherin, 1983), or the extent of the 
responsibility defenders of a strong exemplary role aim at is debated "wo do not be all things to all people or to believe that we have total responsibility for providing all services (Totten, 1983).

The question whether and so, where and when, teachers, nurses and physicians can fulfil an exemplary role with regard to thealth, is only partially answered; the efficacy of exemplary role even less. With the aid of a review of the literature of health education (chapter 2) heaith behaviour (chapter 3), exemplary role (chapter 4 ) and health education (chapter 5) and on the basis of the results of nationwide surveys among teachers, nurses and physicians on the perception of their health educational tasks (chapter 6), their health behavior (chapter 7), and the perception of their eventual exemplary role with regard to health vis a vis respectively their pupils and their patients (chapter 8), elements will be provided to answer the quastion more extensively.

\subsection{Central questions}

Lay people, primary health care workers, and specialist health workers all have an important role to contribute to maintenance and improvement of the populations' health status. In this investigation the focus is on the health educational aspects of the performance of professionals engaged in primary health care and education.

Central questions are:

1. How do key health professionals perceive health educational aspects of theil tasks? The literature is reviewed in chapter 2 and the results are presented in chapter 6.

2. What is the nalure of key health professionals' health behavior in the light of current health norms? Do key health professionals behave differently from the general population? The literature is reviewed in chapter 3 , and the results are presented in chapter 7 .

3. Do key health professionals recognize that they are part of others' social environment and thus can influence their health behavior more strongly? The literature is reviewed in chapter 4 , while the results are presented in chapter 8.

4. Do relationships exist between health behavior, perception of the exemplary role and of health education?

The answers to these questions are expected to be relevant to the implementation of WHO Health for All by the year 2000-Strategy in the Netherlands especially with regard to the targets:

"Target 15. Knowledge and motivation for healthy behavior

By 1990, education programmes in all member states should enthance the knowledge, motivation and skills of people to acquire and maintain health.

The attainment of this target could be significantly supported by ensuring an adequate and effective infrastructure and funding for health education programmios at all levels.

Target 16. By 1995, in all member states, there should be significant increases in 
positive hoalth behavior, such as balanced nutrition, non-smoking, appropriate physical actrity and good stress management.

This could be achieved if clear targets in these areas were set in each member state, a.g. a minimum of $80 \%$ of the population as non-smokers and a $50 \%$ roduction in national tobacco consumption, and if steps were taken by WHO and other international organizations to promote cooperation in health promotion activities throughout the region in order to make a wider impact on basic health values.

Target 29. By 1990, in all member states, primary health care systems should be based on cooperation and teamwork between health care personnel, individuals, families and community groups. This could be achieved by policies in the countries that clearly define the role that different categories of health and social personnel should play in health care; basic, specialist and continuing education programmes for health personnel that provide insight, motivation and skill in interprofessional teamwork and in cooperation with individual families, groups and communities; and health education programmes that provide a realistic picture of what services can be expected from health protessionals and give help in developing lay care skills (WHO, 1984; WVC, 1986a, 1986b)".

An important restriction of the investigation is that the view of the people, key health professionals work with and work for, the children taught by the teachers, and the patients taken care of by community nurses and general practitioners is not represented here. The perspectives of key health professionals dealt with here are important enough to be elaborated separately, however. Parallel investigations on the Dutch population's health perceptions and behavior were reported elsewhere (Adriaanse, Drop. Halfens, Philipsen, 1981; Halfens, Drop, Phillpsen, 1984; Halfens, 1985).

\subsection{Summary}

The concept of health education is discussed and core elements relevant for purposes of this investigation summarized: these are the existence of a relationship between health and behavior, the freedom of personal choice, the participation by those lay people concerned and the systematic character of the efforts to induce change. As elsewhere the concept of health education is not yet a clear notion. On the contrary, health education is observed to be used as a "container" notion. The important position of school teachers, community nurses and general practitioners as key health professionals, in relation to pupils respectively patients is outlined. Recent developments concerning health oducation in teaching, nursing and medical practice as well as conceptualizations of health education in these sectors, are mentioned. A model of health education is seen to be developing in the Netherlands over the last decades. Exemplary role and health behavior are introduced as central concepts in the study. The literature on exemplary role with regard to health behavior is for a large part persuasive or pertaining to opinions about it. The study aims at analysis of exemplary role recognition and fulfilment and its relations to the perception of health educational tasks. The results are expected to be relevant for the preparation of health professionals and future health policy development, especially the intended implementation of the Health for all by the year 2000-Strategy. 


\section{References}

AAPHERD (American Association for Physical Health, Recreation and Dance) Position Statement 1971. Smoking education: the schools' responsibility. Joumal of School Health 8, 444-445.

Adriaanse, H., Drop, M.J., Halfens, R.H., Philipsen, H., 1981. Leeft Nederland Oké? Maastricht/ Zeist. (Report on the health conceptions, experiences and behaviors in the Netheriands).

Adriaanse, $H$, Rouwenhorst, W., 1982. Curriculumplanning for health education in the Netherlands. The case of Maastricht. Paper presented at the 11 th Intemational Conference in Health Education of the International Union for Health Education, Hobart, Tasmania.

Alkker, A.M.E.A. van den, Visser, A.P., 1984. Ervaringen met gezondheidsedukatie in het Amsterdamse basisonderwijs. Vrije Universiteit, Amsterdam. (School health education experiences in Amsterdam elementary schools).

Baric $L_{n}$." 1972. The behavioral sciences as a basis for health education. In: Baric, L. (Ed.). Behavioral sciences in health and disease. Health Education Councill, London, p.2-32.

Bates, I.J., Winder, A.E., 1984. Introduction to health education. Mayfield. Palo Alto.

Van Beilen, E., 1985. Local health education: the upstream movement: In: Harkin, A.M. (Ed.). Health for all by the year 2000: meeting the challenge. 12th World Conference on Health education, Dublin 1985. 122.

Berkman, L., Breslow, L., 1983. Health and ways of living. The Alameda County Study, Oxford University Press, New York.

Centrale Raad voor de Volksgezondheid, 1962. Advies betreffende GVO in Nederland. Mededelingen en Verslagen betreffende de Volksgezondheid, 10, 1059-1261. (Advice on Health Education in the Netherlands).

Dekker, E., 1982. Procesgerichte beleidsontwikkeling voor Gezondheidswoorlichting en Opvoeding. National Center for Health Education Bunnik. (Proces-oriented policy development for health education).

Dekkers, F., 1984. Patientenvoorlichting. De onmacht en de pijn. Ambo, Baarn. (Patient education; powerlessness and pain).

Derryberry, M.n 1982. Health education. Its objectives and methods. In: Simonds, S.K. (Ed.). The philosophical, behavioral and professional bases for health education. SOPHE Heritage Collection of Health Education Monographs. Vol. 1, p.5-11. Third Party, Oakland.

Van der Does, $E_{., 1} 1981$. The doctor and health information and education. In: P.Recht (Ed). The role of the physician in health education. Proceedings International Symposium of the Commission European Communities, Brussels/Luxembourg, 37-50.

Doll, R., 1983. Prospects for prevention. British Medical Journal 286, 445-453.

Egsmose, T., 1977. The role of health prolessionals in smoking education. In: Proceedings Third World Conference on Smoking and Health. Vol. II. USDHEW. Washington. p.255-264.

Finn, P., 1981. Hey teach, do you drink? Joumal of School Health 10, 538-542.

Green, L.W., Kreuter, M.W., Deeds, S.G., Partridge, K.B., 1980. Health education planning: a diagnostic approach. Mayfield "Palo Alto.

Haes, W.F.M. de, Schuurman, J.H., 1979. Cok patientenvoorlichting is GVO. Medisch Contact 23, 727-731. (Patient education is also health education). 
Hagendoom, H., Verburg. H., 1986. GVO in de Jaren tachtig. GVO \& Preventie 2, 5-13. (Health aducation in the 1980s).

Halfens, $\mathrm{F}_{*, 1}$ 1985. Locus of control: beheersingsorientatie in relatie tot ziekte en gezondheidsgedrag. (Locus of control in relation to illness and health behavior). (Dissertation, University of Limburg, Maastricht).

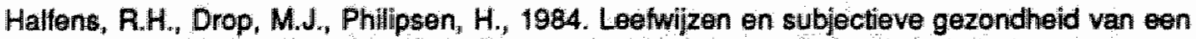
panel uit de Nederlandse bevolking. Maastricht. (Life-sityle and subjective health of a panel from the Dutch population).

Hansison, P., Visser, A.P., 1984. Gezondheidsedukatie in het basisonderwijs. Van Gorcum, Assen. (Health aducation in elementary schools).

Hatch, S., Kickbusch, I., 1983. Selfhelp and health in Europe. WHO, Copenhagen, 1983.

Hegger, W, 1979. Onderwijs in gezondheid; leerstofstrukturering bij gezondheidsvoorlichting en opvoeding. Jeugd en Samenleving, 428-441. (Education for health; curricular structure for health education).

Hegger, $W_{n,}$ 1980. Gezondheidkunde in de lerarenopleiding voor het basisonderwijs. ACLO Gezondheidskunde, Enschede. (Health education in elementary teacher training).

Hegger, W., Hameren, J.A.M. van, 1981. GVO in het onderwijs. Deel 5. Elndadvies Kommissie Nationaal Plan GVO. Staatsuitgeverij Den Haag. (School health education).

Kickbusch, I., 1981. Involvement in health; a social concept of health education. International Journal of Health Education $4_{4}$ supplement 1-13.

Kok, G.J., 1986. Gezondheidsmotivering; GVO als wetenschapsgebied. Gezondheid en Samenleving 6, 58-68. (Health motivation: health education as a scientific domain).

Kommissia Nationaal Plan GVO, 1981. Eindadvies. Delen 1-7. (Final Report: National plan for health education (Part 1); National functions and structures for health education (Part 2); Health education at the local and regional level (Part 3); Financing of health education (Part 4); School health education (Part 5); Proffessional preparation and training (Part 6); Research and research planning (Part 7). Staatsuitgeverij, Den Haag.

Studie Kommissie Koninklijke Nederlandse Maatschappij ter Bevordering van de Geneeskunst (KNMG). Rapport Gezondheidsbevordering. Medisch Contact 6, 181-194. (Report on Hoalth Promotion).

Lamberts, A., 1981. Patientenvoorlichting: een heel gewoon onderdeel van de huisartsgeneeskunde. Huisarts en Wetenschap 24, 263-268. (Patient education: a very normal part of general practice).

Lazenby, 1984. Nurses gain new image als non-smokers 1984. RN ABC News 2,6-8.

Lens, P. 1984. Zleke dokters. Bunge, Utrecht. Dissertation, University of Leiden. (Sick doctors).

Levin, L.S., Kalz, A.H., Holst, E, 1979. Selfcare: lay initiatives in health. Prodist, New York.

Mertens, S.M.C., 1983. Ontwikkelingen in het werk van de wijkverpleegkundige. De Tijdstroom, Lochem. (Developments in the community nurse's work).

Ministerie van Welzijn, Volksgezondheid en Cultuur, 1984. Gezondheidszorg bij beperkte middelen. WVC, Leidschendam. (Health care in retrenchment).

Ministerie van Welzijn, Volksgezondheid en Cultuur, 1986a. Health for all by the year 2000" rapportage Nederland 1985. Leidschendam. 
Ministerie van Welzijn; Volksgezondheid en Cultuur, 1986b. Over de ontwikkeling van gezondheidsbeleid: feiten, beschouwingen en beleldsvoornemens. Tweede Kamer der Staten Generaal 1985-1986, 19500; 1-2, Den Haag. (On the development of health policy: facts, discussions and intentions).

Muskens, G.J. 1985. Vernieuwing door GVO? Een onderzoek in de wijkverpleging. In: Boema, W.G.W. \& Hingstman, L. De eerste lijn anderzocht. Van Loghum Slaterus, Deventer, p. 128-134. (Innovation through health education?)

Muskens, G.J., 1984. Wijkverpleging en GVO: inventarisatie en aktie in acht basiserenheden. IVA, Tilburg. (Community nursing and health education: inventory and action in eight teamis).

Nationale Kruisvereniging (1986). Kruiswerk en GVO: nieuwe trends. Een beleidsnota over Gezondheidsvoorlichting en -Opvoeding vanuit het Kruiswerk. Bunnik. (Green Cross Care delivery and health education: a pollicy report).

Nationale Kruisvereniging (1987). Kruiswerk in beweging: verantwoording $1981 \mathrm{tm} 1986$; Meerjarenraming $1988 \mathrm{t} / \mathrm{m}$ 1992. Bunnik. (Green Cross Care changes: Report on 1981 1986; prognosis 1988-1992).

Nutbeam, D. 1986. Health promotion glossary. Health Promotion International Journal 1, 113-127.

Rouwenhorst, W., 1977. Leren gezond te zijn? Samsom, Alphen a.d. Rijn. Dissertation University of Utrecht. (Leaming to be healthy?)

Rouwenhorst, W. 1981. Om anze gezondheid: de rol van GVO. Samsom, Alphen a.d. Rijn. (Our health at stake: the role of health education).

Rouwenhorst, W., 1982. GVO: Quo vadis? Valedictory lecture. University of Limburg. Maastricht. (Health education: Quo vadis?)

Shangold, M.M., 1979. The health care of physicians. (Editorial). Journal of Medical Education 56, 668.

Sherin, $K_{i}, 1983$. Lelter to the Editor. New England Joumal of Medicine 23, 1425.

Sliepcevich, E. School Health Education Study. Health Education: a conceptual approach to curriculum design, 1967, Washington DC.

Simonds, S. Rouwenhorst, $W_{\text {., Adriaanse }} H_{\text {. }}$ Damoiseaux, V., Dubois, V., Saan, H., 1981 . Exit levels competencies for health education in the social health program at the University of Limburg. Maastricht. University of Limburg, Maastricht.

Sliepcevich, E.M. 1964, School health education study: Summary report of a nationwide study of health instruction in the public schools, SHES, Washington.

Smith, 1984. Prevention by example. Nursing Mirror 13, 17-18.

Smits-Van Sonsbeek, B, Hegger, W., 1976. Gezondheidswoorlichting en -Opwoeding in het onderwijs. Jeugd en Samenleving, 701-714. (Health education in schools).

Steuart, G.W., 1965. Health, behaviour and planned change. Health Education Monographs 20. Society of Public Health Education. New York.

Teunissen, O.M., 1982. The school health program in the Netherlands. ACLO, Enschede. (Unpublished).

Totten, M.A. 1983. Letter to the Editor. New England Journal of Medicine 23, 1424-1425. 
Wafelbakker, $F_{\circ}$ 1987. Mijn dokter rookt (niet); voorbeeld en invoed van de arts. In: Adriaanse, H.P al al. Roken en Longen: ontmoedigingsbeleid en de rol van de huisarts. Uligeveril De Medicus, Leiderdorp, p, 53-57. (My doctor does (mot) smoke: example and influence of the physician).

Wechsier, H. Levine, S., Idellson, R.K., Rohman, M., Taylor, J.O., 1983. The physicians" role in health promotion. A survey of primary care practitioners. New England Journal of Modicine, 2, 97.

Wells, K.B., Lewis, C.E. Leake, B., Ware, J., 1984. Do physicians practice what they preach? Journal of the American Medical Association 20, 2846-2848.

Werkgroep GVO In het basisonderwijs, 1972. Gezondheidswoorlichting en -Opvoeding in het basisonderwijis. staatsuitgeverij. (Task force on elementary school health education).

Wortd Health Organization, 1975. The preparation of health personnel in health education. WHOI Euro, Copenhagen.

World Health Organization, 1985. Targets for health for all. WHO/Euro, Copenhagen.

Wijnsma, $P_{*, 4}$ 1986. Profilering en identiteit van gezondheidsedukatie. GVO \& Preventie, 1, 31-36. (Profile and identity of health education).

Yarrow, A., 1977. Key health prolessionals as educators. Proceedings Third World Conference on Smoking and Health, Vol. II. USDHEW, Washington DC, 423-428.

Zielhuis, G.A. 1985. Structuurrapport Preventie. Tijdschrift Sociale Gezondheidszorg, 25, 1047153. (Report on Prevention). 


\section{Chapter 2. Health education}

2.1 Conceptualization of health education

2.2 Health education in schools, nursing and medical practice

2.3 Schoolteachers' conceptualization of health education

2.3.1 International

2.3.2 In the Netherlands

2.3.3 Role expectations, role performance

2.4 Community nurses' conceptualization of health education

2.4.1 International

2.4.2 In the Netherlands

2.4.3 Role expectations, role performance

2.5 General practitioners' conceptualization of health education

2.5.1 International

2.5.2 In the Netherlands

2.5.3 Rolle expectations, role performance

2.6 Discussion

2.7 Conclusions

2.8 Summary 


\section{Introduction}

The most important variable in this investigation is health education, more precisely the health educational aspects of the work of first line health care providers and teachers. Their perceptions of health education as well as activities ranged under that notion, will be analysed in relation to professionals' health behavior and their perception of an eventual exemplary role.

In this chapter the literature on health education in the work settings of nurses, physicians, and school teachers is reviewed. Firstly, the way health education is conceptualized within these professions internationally, is reviewed. Then, more specifically the Dutch developments with regard to health education in teaching and nursing settings as well as in general practice are outlined. Finally, role expectations and role performance pertaining to key health professionals' health education are discussed.

\subsection{Conceptualization}

Before reviewing in detail how health education is perceived and performed by by teachers, nurses and physiclans, it is necessary to clarify the concept of health education further. As was shown in paragraph 1.1 four elements seem to form a common core of a number of health education definitions: the relation between health and behavior, the voluntary personal choice, the participation of those concerned and systematic change efforts. Though health education is a function that can operate in many senses (Rouwenhorst, 1981) (see Chapter 1, page 10), health education will be restricted here to the sense of an instrument to maintain and improve health by educational means. Health education can be applied within the health care system by nurses, surgeons or physiotherapists as well as in education by teachers in any discipline, but also in industries by management trainers or in sport centers, by bar tenders, or by (ex) patients to other lay persons recently fallen ill.

Heatth education terminology has grown bottom-up, from practice to the academic level. Only after health education terminology had been used for decades the diversity of conceptions has proliferated and has begun to hamper professional activities both in the USA (Koski. 1978) and on the European continent, efforts were made to define health education and related concepts. In the USA a Joint Committee on Health Education Terminology was created in 1972 by several organizations of health professionals, and a Thesaurus of Health Education Terminology was published in 1976. In this thesaurus health education is defined as an educationally oriented process of planned change which focuses on those behaviors or problems that directly or indirectly affect people's health (USDHEW/CDC, 1976).

In his chapter "A la recherche d'une définition d'Education pour la Santé", Colton reviews a number of health education definitions to conclude by giving his own definition integrating the essential elements.

"L"Education pour la santé est un processus d'action réciproque entre personnes qui entraine l'acquisition ou la transformation du comportement de certaines d'entre elles et les amène à choisir à bon escient les ressources nécessaires a l'utilisation optimale de 
leur potentiel de santé pour éviter la maladie et promouvoir lo bien-être physique, mental et social, tant pour beneficier olles-mêmes de celul-ci que pour participer a celul de la communaute" (p. 22).

"L"Education pour la santé est aussi un processus d"action qui fait apparaître dans le groupe social de nouvelles normes nécessaires a l'adaptation permanente du groupe et des individues qui le composent à des conditions de vie sans cesse changeantes, de façon telle que la contormité des conduites a ces normes sauvegarde et amóliore le bien-être physique, mental et social de la communauté et contribue ainsi a la promotion de la santé et du complet bien-être des individus" (Cotton, 1982, p.22).

This integrated definition contains the essential elements listed earlier in this paragraph. They also appear in a series of important definitions, produced by WHO. In 1954 Health Education was defined by this organization as: "All those experiences and processes by which people's attitudes towards their own and the public's health may be guided and all the influences that will improve the health behavior of the individual and the health level of the community, aiming at helping people to achieve health by their own actions and effect." (WHO, 1954, cited in Simonds et al., 1982, p. 8).

In the sixties WHO adopted a somewhat more ambitious phrasing of its Health Education definition: "Health Education is to encourage people to adopt and to sustain healthful lite practices, to use judiciously and wisely the health services avallable to stem and to make their own decislions both individually and collectively to improve their health status and environment" (WHO, 1969, cited in Simonds et al., 1982, p.8).

Recently, WHO put more accent on health promotion than on health education; the latter being defined as: "consciously constructed opportunities for learning which are designed" to facilitate changes in behavior towards a pre-determined goal". Health promotion is "the process of enabling individuals and communities to increase control over the determinants of health and thereby improve their health" (Nutbeam, 1986). Health education is considered to be a crucial tool for health promotion. If health education is not always the most important tool, it certainly is the first tool to be used in heatth promotion (Green, 1988). Clear and short is Griffith's definition of health education as a process to bridge the gap between what we know and what we do about our health (President's Committee on Health Education, 1974).

\subsection{Health education in teaching, nursing and medical practice}

In this section the place of health education within the three professional groups will be described. Conceptualization of health education within the professions" actual role performance and role expectations among the professions and among the public are reviewed. The literature review cannot possibly be exhaustive; it is restricted to those sources that were relevant to developments in the Netherlands. 


\subsection{School teachers' conceptualization of health education}

\subsubsection{International}

Health education in schools takes place not only through courses of instruction, but also through living in the school as an institution and through experiences in practice teaching. In the primary school, teachers are especially concerned with the growth of health attitudes and practices among children and less so with imparting health knowledge. "Depending on a country's policy, the attitude and skills of the teacher; he or she can provide invaluable leadership to Health Education developments in - and outside the school" (WHOUNESCO, 1960, p.7). The developments since then are perhaps best characterized by Simonds, who stated in 1963 that "education for health will be successful to the extent information from the biomedical and social research centers can be communicated to teachers more effectively", while in 1977 he reworded the statement as follows: "Education for health will be successful to the extent that useful information from biomedical and social research can be communicated to all responsible for Health Education in a way that is helpful" (Simonds, 1977). There is more emphasis on the social environment as a whole in Simonds' latter statement and "intormation about health" is restricted by usefulness. The emphasis on the social enviroment is even stronger in Smith's view of comprehensive School Health Education. She postulates that health is the foundation of the educational process and that everyone employed in schools in fact teaches health, not only teachers and specialists, but also foodservice staff, administrators, secretaries, and so on, are teaching health by example through the lives they lead (Smith, 1983). This conceptualization, though inspiring, does not delineate School Health Education operationally, and thus both role and scope of Health Education are to remain rather nebulous. Hoste attempted to clarify this situation by interviewing teachers in England, but discovered mainly a vast amount of variability in the teaching and in the organization of Health Education (Hoste "1978).

In the analysis of the contribution of school health education to community health promotion, it was concluded that school health education had three important rolles:" understanding of health and disease, reinforcement of positive health attitudes and the alteration of concurrent health behaviors for significant health problems, Although school health education may be helpful in enhancing decision-making and social interaction skills supporting evidence is scarce (Bartlett, 1981; Kolbe, 1982).

Peviewing theory and practice of School Health Education, Stone and Rubinson define as major goal: "to promote favorable behavior in situations involving the individual's health" (Stone and Rubinson, 1979). A more enlightning attermpt to conceptualize School Health Education was made in 1983 on the one hand by a review of the theoretical models applicable to School Health Education, comprising behavioral change theories like social learning theory, theory of reasoned action, social competence theory. These theories provide structure for addressing teaching and learning about which still many questions remain unanswered (Parcel, 1984). In a conceptual approach to school based health promotion, Perry distinguishes four domains of health: the physical, social, psychological and personal domains and operationalizes complementary health promotion strategies focussing on behavior, personality and environment (Perry, 1983). About one third of the prevention objectives proposed for adults and children by the US 
Government could be directly attained of substantially influenced by health promotion activities in the schools. The role of families and teachers in the maintenance of schoolinduced behavioral changes outside the school, is seen as an important research question (Perry, 1984). Recently, Green \& Iverson defined school health education operationally as any combination of learning experiences initiated by personnel in the (pre)school, or college setting to develop the behavioral skills required to cope with the challenges to health expected in, and the cognitive skills required to comprehend the further learning, scheduled for the students immediate years ahead (Green \& Iverson, 1982).

In Russia, Selivanov, Zaplanikov, Smolenskaya ot al. posit that the primary interest of a teacher must not lie in the subject of health education itself, but in the attitude towards the work, the readiness to start activities and skill training (Selivanov, Zaplatnikov, Smolenskaya, Pitkovskaya \& Tsjagorets, 1986).

\subsubsection{Conceptuallzations of Health Education in schools In the Netherlands}

As early as 1871 it was proposed to integrate health education officially in the school system; the actual integration took place 114 years later, in 1985 when the new Law on elementary education was enacted. This had been pleaded for regularly, especially from the field of social medicine (Doeleman, 1961; Kleiterp, 1954; Rouwenhorst, 1977).

In 1973, the University of Nijmegen's Hoogveld Institute for Social Research started a health education project aiming at curriculum development for elementary education, as well as assessment of effects of its implementation on the schoolchildrens' health knowledge, -attitudes and -behavior, and physical condition. The Hoogveld Institute based its health education project on the School Health Education Study's core concepts: 'growth and development", "interaction' and 'decision-making". Health education is conceptualized as making children aware of the significance of the three core concepts for their health and safety (Hegger, 1979a; Saris, Binkhorst, Cramwinckel, Hegger \& König, 1982; Smits-Van Sonsbeek \& Hegger, 1979). Until today the Hoogveld Institute's School Health Education project has an exemplary role in School Health Education in the Netherlands. Curriculum development for elementary education has been completed, while curriculum development for teacher training colleges was developed on the same basis (Van Geffen, Hegger \& Voragen, 1985). Themes covered by the eight year curriculum are nutrition, dental care, physical activity, personal care, safety in traffic and at home, the use of health services and health products and environmental pollution. Mental health aspects were not explicitely included.

Selfempowerment, enabling people to stand for their health interests is the central goal of the Hoogveld Institute's Health Education project (Hegger, 1979a). The role of the teacher formerly was characterized by authority. The new role expectations for the teacher imply an explorative, encouraging role. Teachers' task is a value clarfication, widening the scope of personal choices in health and enhance healthful and safe behavior (Hegger, 1979a).

In 1977 a local health education project was started in Amsterdam with a different perspective (Hansson \& Visser, 1980; $1981 \mathrm{a}, \mathrm{b}, \mathrm{d}$ ). It was not aiming primarily at curriculum development but at interorganizational development of structures allowing to 
create experimentally, on the basis of local needs and demands of all participants, the best fitting health education program. Teachers, parents, schoolchildren, as well as school guidance and counseling services, school authorities and -administration, all being actors in the decision-making process on the school's curriculum were involved. There was no particular health education conception put ahead of the program (Hansson \& Visser; 1984). The bottomup approach used in Amsterdam showed that among teachers as well as among other instances involved, there is a failr degree of uncertailnty about health education methods and -objectives: no systematic health ediucation planning mechanisms developed from the process (Van den Akker \& Visser ; 1984).

There has never been much attention for the mental health aspects, the omission of which in the conceptualization is mostly being taken for granted. Lack of clear objectives and adequately trained teachers are major obstacles for the realization of the necessary development of mental health education pleaded for by Gerards (1983).

Before turning to some results of research on role expectations and role performance with regard to health education, it should be stressed that, although some useful elements for a theoretical conceptual identity of Health Education in schools have been applied in this country, this did not result in an accepted identity of health education among school teachers, parents, or even less in politics or society at large (Van Hameren, 1980). There is a consensus however, about the three pillars of school health education being the school environment, the school health services and the curriculum, in the framework of which teaching and learning about health actually takes place (Teunissen, 1981). Judgements on actual school health education developments in the Netherlands are quite varying. The new Law on Elementary Education, integrating health education in curriculum would have triggered an enormous development (Drailer, 1985). The teachers in the US and in the Netherlands have the best position to implement school health education (Bensley, 1986). On the other hand reported to exist: the school health curriculum is largely empty, coordination is lacking, there is hardly any demand for continuing education, health education has no priority the Ministry of Health does not provide directives, technical curriculum planning support is needed but not given by schooll support services, health education specialists are rarely seen in the school systems (Hegger, 1986, Wiersma \& Suhre, 1987). Identity and profile of "gezondheids edukatie" (school health education), the problem of its domain and related task delineation will stay high on the agenda in the near future (Wijnsma, 1986).

\subsubsection{Role expectations, role performance}

In an investigation into teachers' role perception with regard to health education in thirteen teacher training colleges in England, toachers ( $N=160)$ appearod to be in favour of health education being part of all subjects where it fits in. Only a small group opted for health education as a separate course. Major obstacles likely to arise when attempts for Integration of health education in the curriculum are made, come from the teachers themselves, from their own expectations of what their jobs should be. A considerable number of teachers want to teach their own subject only, while others see their primary role as equipping pupils with basic skills, or contributing to school life in general. These role perceptions modify the conception of health education. Most teachers' role perception was to equip pupils with basic skills and considered health education to be aiming at that type of skills (Charton, 1981). 
The effectiveness of school health education is ultimately determined by whether it is implemented and how it is implemented. The actual impact depends upon how school health education is initiated, disseminated and maintained (Kolbe \& Iverson, 1980). In their extensive review on the implementation of comprehensive school health education, Kolbe \& Iverson imply the crucial importance of the teachers' rolle: "Schools could be an agent vitally important in the realization of a second public health revolution (Kolbe \& Iverson, 1981). In a review of research into effects of school health education projects in the US, the scope of these studies appears to be smaller than desirable, being limited for the most part to attitudes and behaviors related to smoking. Comprehensive systematic evaluation taking into account teachers' attitudes and behaviors is necessary (Olson, Redican \& Krus, 1980).

In Spain, role expectations for the teacher were labeled as "educador de salud" and even "policia sanitario", 1.e. sanitary supervisors responsible for early detection (Sieres \& Soriano, 1984). In Bellgilum, exploratory research into the effects of scheol health education implementation, carried out among elementary school teachers $(\mathrm{N}-587)$ and school boards $(\mathrm{N}=233)$, with an overall response rate $57 \%$, a large participation in continued education for school health education was registered: $64 \%$ of the teachers and $73 \%$ of the boards participated. The influence on reported school health education activities was surprisingly high (Belgisch Rode Kruis, 1983).

In 1985, in the framework of the assessment of the first phases of the introduction of health education in the Flemish elementary school system, Verhoeven \& Suetens surveyed a representative sample $(N=949$; response rate $=71 \%)$ of teachers in Belgium. Task perception with regard to health education was measured. Among young teachers as well as among the oldest group of teachers, age 52 and over, a stronger inclination to integrate health education in teaching practice was found than among the middle aged group. It is remarkable that no relationship of health education task perception and health behavior was found. Of the Flemish teachers $70 \%$ considered health education to be part of their professional role. Nevertheless parents were seen as having primary responsibility for the health education of their children; teachers only perceive a secondary responsibility (Verhoeven \& Suetens, 1985).

The Hoogveld Institute assessed the implementation of school health education in 1985 among thirty elementary schools partly participants in their project described here above, partly non-participating schools. This evaluation showed that there is a need for a central coordination point for health education in a school. Teachers appeared to consider nutrition, dental care, pollution, personal care and traffic safety as self-evident health education themes. Safety at home, exercise and social-emotional developments are perceived as implicit health education themes, considered to be important aspects of the curriculum. Teachers had an ambivalent attitude towards sexuality, addiction, growth and development and the use of health services and products. Health education is not considered as new subject matter but as being integrated in other areas. Curricular materials developed by the Hoogveld Institute were hardly used by schools not participating in their project. A clear nead for continuing education in health education was felt. Teachers also expressed the need for more contact with regard to health education with school childrens" parents. The educational concept most teachers adhered to was to join the child's experiences" (Panis, Veerman \& Van Kesteren, 1985). 
The introduction of health education in a sample of Amsterdam elementary schools was assessed in 1984, by means of interviews involving 26 schools. Teachers appeared to have a positive attitude towards health education. They considered the transfer of health knowledge only insufficient, and taking into account childrens' personal experiences was seen as essential. Teachers aspired to spend time and attention to health education in a systematic way. However, although their attitude towards health education was positive, this did not mean that in practice, health education themes got a lot of attention. Major obstacles preventing Amsterdam teachers in the actual situation to devote as much attention to health education as they would want, were a lack of experimenting space in the curriculum, Insufficient preparation of the teaching team, lack of curricular integration of health education, lack of appropriate health education materials as well as low motivation to behave exemplarily. Teachers had scarce contacts with school administrators as well as with parents concerning health education, a circumstance which seriously hampered systematic development of health education. Teachers did not perceive it as part of their task to educate parents about their presumably partly unhealthy behavior, while they clearly see the need for a confluent approach of health education in school and in the family (Van den Akker \& Visser, 1984; Hansson \& Visser, 1981; 1984).

In Belgium, where in an investigation among Flemish teachers $(\mathrm{N}=137)$ two thirds of the teachers stated the school had to play an important role for children's health education, simillar conditions as reported for the Netherlands, were found (Heyerick, Maes, De Maeseneer, 1981).

In an assessment of the effects of school health education in Tilburg, the Netherlands, with regard to physical health education, positive effects were found on knowledge of biology and physics, on health knowledge and -attitudes (De Kok, 1986). The results of this small scale study in the Netherlands are in line with the experiences the Growing Healthy curriculum in New York City: There, students who were exposed to the Growing Healthy curriculum had higher rates on the three R's than those not exposed (Goldman \& Pearson, 1986).

As conditions for adequate teacher training in the field of health education, horizontal, vertical and transversal integration was pleaded for by Hegger. Horizontal integration means the non-disciplinary theme-centered approach, vertical integration the continuous exchange between theory and practice and transversal integration the impact on and the consistency of professional and personal growth and development (Hegger, 1980).

\subsection{Nurses' conceptualization}

\subsubsection{International}

In the literature at many places exhorations by the profession to the profession are found, pointing at the necessity of the health educational role of the nurse, independently of health care system characteristics.

In the USA, an experiment with a new type of nurse, the nurse practitioner, is reported by Lewis. The analysis is that health education best can be delivered in a one-to-one 
contact, via community oriented hospitals and/or hospital sponsored primary care facilities. Physicians being the first choice for the educational role, cost and scarcety are prohibiting. The family practice nurse should take this role, under physician supervision. Family practice nurses have more time, are frequently avallable and able to provide health education as a routine part of care, while emphasizing that individuals are responsible for their own health. Lewis refers to a 1974 American law, the National Health Planning and Resources Development act, that lists the national health priorities, three of which pertain to health education: (1) the development of health maintenance organizations; (2) prevention and (3) the development of effective methods of educating the general public concerning proper personal health care. According to Lewis family practice nurses can play a key-role in the realization of these national health priorities (Lewis, 1978).

Starting his discourse at the most prevalent health problems, l.e. the use of tobacco and immoderate alcohol consumption, road accidents, dental decay, mental illinesses and what is called the sexual revolution. Smith points at the great potential influence of the nurse. Nurses' training should be focused more strongly on prevention of these risk factors and less on disease. Rather ostensively it is stated: "The health education process, I do believe, is part and parcel of the nursing process. It, therefore, follows that greater involvement of nurses in health education in the 1980 's is a logical and rational extension of their role" (Smith, 1979, p.542). The same type of persuasive argument is used with regard to the French nurse, considered to be a "personne charniere" in patient

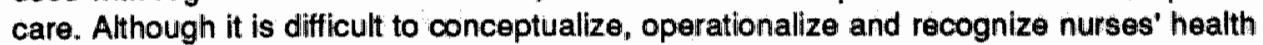
educational role, according to Fortias, she gives a pertinent and optimistic view: "Savoir si llintirmière a un role pédagogique à jouer, nous en sommes maintenant terriblement conscients. Alors, de grâce, ce rôle, jouons-lel" (Fortias, 1980, p.54).

Others are less optimistic: though nurses have had an educational role historically due to their unique position enabling them to demonstrate the contribution of health education to enhanced quality of living in general and to reduce health care cost in particular, this position is in danger! Nurses have given up their power and responsibility for health education to other disciplines (Evans, 1980). For example, the nurse practitioner, a type of physician"s aid, can provide "the human element needed to perform this vital service" (Lewis, 1978). A number of authors argue nurses should play a health aducational role with regard to specific health problems, for instance smoking, breastcancer, etc. (Pender, 1982). With regard to the latter disease, nurses appear to feel a responsibility for their educational role but only one fourth of the patients consider nurses an important source of information, an emotional support. There is a gap between professional self perception and nurses' actual role as seen by the public (Bullough, 1984; Knopf-Elkind, $1980)$.

\subsubsection{The conceptualization of health education In nursing In the Netherlands}

Reports on practical Health Education activities were scarce. Most writing on Health Education in nursing practice is speculative or persuasive in nature. From their review of the literature, Dekens and Wieberdink conclude that most Health Education tasks are implicit and lie at the level of secondary and tertiary prevention. Preventive activities are 
presumably underreported. Physical aspects get most mental and social aspects get less attention, in that order (Dekens \& Weberdink, 1979).

According to Johannesma (1982) reflecting on the educational role of the nurse, this role can be described as a systematic help to overcome impediments to normal functioning by means of education and information. The educational task of the nurse implies the provision of relevant information concerning normal functioning, guidance of the learning process to acquire new behaviors to give instructions to enable people to live with handicaps or in suboptimal circumstances, and finally is holistic human and futureoriented. She points out that the nurses" perspective is not a medicalized perspective on education, because it is not illiness - but health - oriented (Johannesma, 1982).

In her contribution to the First National Conference on Health Education in the Netherlands, Ruiter described health education within community nurses' work as follows: the community nurse considers the individual in the context of his/her day-to-day life, takes into account the social environment; the community nurse aims at increasing the individual's awareness of his/her responsibility for own health, the community nurse has to be aware of the anthropological view he/she is implicitly basing the activities on. Finally, she too postulates the interwovenness of health education all through community nurses' work (Ruiter, 1982).

In community nursing, health education has always been seen as part of all health workers' jobs. Cooperation within and outside health care always has been self-evident, as have been the stimulation of own responsibility for health, the facilitation of self-help and mutual aid and the attempts seeking public's participation for health causes (Mertens, 1983).

In a recent policy paper, the National Cross Union, employer of most community nurses in the Netherlands restated that community nursing has implicit health education tasks linked with actual care, and explicit health education tasks aiming at prevention. It was observed, however, that curative tasks ask more and more of community nurses" time. Other problems are the diversity of health education conceptions and the lack of communication about health problems between community nurses and the population. As a new goal, local "up-stream" health education was identified, while local health educators are being appointed to coordinate these offorts (National Cross Union, 1986).

Local health educational efforts would comprise as tasks: the delivery of prestructured courses; mental health education: discussion groups on general health themes; development and organization of new types of care needed; support of mutual aid/ selfhelp groups; the organizations of public campaigns, of health-theme centered big group meetings, the fulfilment of a clearing house function. Naturally close coordination with local community nursing is considered to be a prerequisite. After a long period in which professionalization of health education had been declining, the adoption by the National Cross Union of this position seems to prelude a major shift in the conceptualization of health education in Dutch community nursing.

\subsubsection{Role expectations, role performance}

Health education is one aspect of community nurses among many, most important of which are curative care, hyglene and prevention and administrative tasks. In an early 
investigation among community nurses ( $N=46)$ into their tasks and time-spending, Doeleman found in 1959 that half of their time was taken by curative care, one quarter by social hygiene and the rest by administration and travel. Considerable internurse. variation appeared: personal attitudes of nurses versus prevention and versus the care/ cure balance, appeared to be major determinants of their actual time-spending (Doelleman, 1959).

Another time and task study revealed that half of the community nurses spent $60 \%$ of worktime out in the community, doing visits for both preventive and curative purposes. Few team-contacts facilitated their activities. As most important tasks the recognition of risk factors and patient education were listed (Knapen, Scheffer \& Hutjes, 1976).

In a qualitative nationwide study among 125 community nurses, a large number of obstacles for the stimulation and facilitation of selfhelp and mutual aid were revealed, hampering health education aiming at self-empowerment (Bultman, Kuiper, Dupon \& Loon-Netjes, 1982; Hattinga Verschure, 1979).

In a comprehensive Health Education program examining cardiovascular risk reduction in Finland, public health nurses as well as physicians performed educational roles. They appeared to be effective, health educators had their efforts lead to subsequent improvement in the public health situation of the population (Puska \& Neittaanmaki, 1979).

Chaze \& Levasseur, by means of in-depth interviews of a nationwide sample of nurses in France, studied the content of their role in a qualitative way. Consisting of relational, helping, administrative and educational components, the nurse's role is rich but unstructured. French nurses predominantly do not consider themselves as health educators. However, they do agree to have a general educational role (Chaze \& Levasseur, 1984).

Faulkner \& Ward, in a study on nurses' role in health education $(\mathrm{N}=222$; response rate = $100 \%$ ) found that the majority adhered to the concept of their role as a health educator with regard to smoking, but did not act congruently in their contacts with patients, due to a poor knowledge base, poor communication skills, lack of motivation and occupational conformity with a 'no health education' norm, existing on the wards. Nurses appeared to be equally ineffective in health education in other areas than smoking (Faulkner \& Ward, 1983).

In 1984, an investigation into the work of community nurses was carried out in three regions in the Netherlands. Minimal conditions for effective health education by community nurses were specified: the nurse must value health education, must be able to spend time on it, must be supported by organizational health education policy and be enabled to deliver health education in a systematic way, i.e. dispose of sound health education methods learned during adequate professional preparation. It was concluded that direct health education to patients in relation to their health was most important in community nurses' work. With groupwise delivery health education community nurses were less familiar, even less with external health education activities initiated by other health workers or lay organizations (Muskens, 1984). Health education now is a legitimate community nurses' task, since the official recognition through the Algemene Wet Bijzondere Ziektekosten in 1980 (Law on the payment of health care costs). 


\subsection{General practitioners}

\subsubsection{International}

The conceptualization of physicians' role in health education has received growing attention over the last years. Here the focus will be on a restricted number of publications pertaining to physicians' role in health education. Literature dealing with the health educational role of the physicians with regard to a specific program, e.g. alcohol, safety, smoking, berlevement, will not be dealt with here.

In the USA, at a conference on physician involvement in health education, summarized by Campbell and Valente, the state of the art of physician health education was characterized by low physician achievement in this field, due to lack of time and questions of cost, unclarity of the physician's role, lack of adequate physicians training and good health education materials. Compeling information sources such as massmedia continually confront people with unhealthy behaviour (Campbell and Valente, 1983). Atthough unable to solve all obstacles reported by Campbell and Valente for the American situation, many authors stress the importance of physicians" role in health education in only partially comparable settings in Europe (Karenko, 1984; Recht, 1981; Von Tröschke \& Stossel, 1981). Operationalizations of physicians' role in health education were developed in North America (Morgan, 1980; US Dept. HHS, 1982; Brunton, 1984; Mason \& Tolsma, 1984; Fletcher, 1985), and in France (Cornillot, 1981), but no applications and assessments of these sets of objectives were reported.

Dismuke \& Miller pleaded for more physician involvement in prevention and health education: in their view there is a clear public demand for it. They argue physicians should play a role not only with regard to smoking, overeating, seat-bett use and excessive alcohol consumption, but also with regard to nutrition counseling, physical exercise and marital counseling. Dismuke \& Muller posit that physicians discovered good healith for themselves in many respects and now should share the secret with the population they serve (Dismuke \& Miller, 1983). Others, however, think physicians already are held responsible for too many subjects: the "should phenomenon", implying general practitioners are already expected to contribute to the solution of (too many) societal problems (Bain, 1986). In this line of reasoning the expectations of the preventionist are too high; some physicians even reluse to see risk factors as belonging to the medical domain, arguing these belong to the ethical and political domain (Skrabanek, 1986).

Nutting concludes in his literature review that, although physicians are willing - and patients are expecting them too - to integrate health promotion activities in their work, there is, as yet, insufficient solid conceptual basis for health promotion and a lack of coherence between health promotion activities. The market, especially third party payers will decide upon redefinition of the physician's role (Nutting. 1986).

In the UK, the role of physicians has been depicted by Backett during the EEC Symposium on the physiclans' role in health education. Backett is conceiving the physician as a scientist who knows how to deal with uncertainty, in contrast to the health educator he considers to be an evangelist, trying to dissiminate indubitable truths. $\mathrm{He}$ considers health education as one of the least simple and most difficult challenges of 
medical care (Backett, 1981).

In France, the role of doctors in health education is considered primordial (Aujoulat, 1966). It is speculated, however, that doctors are neither prepared nor particularly interested in this important aspect of their duties (Fréour, 1980) A comprehensive operationalization of the physicans" health educational role was given stressing the need of demedicalization. At the same time, physicians' key position in health care forces him/ her to add an educational dimension to the majority of physicians'activities (Cornillot, 1981).

In Germany a meeting was held on the role of the doctor in health education bringing together a great number of experts from European countries to give their view on the conceptualization and practice of this part of health educalion. The following distinctions were proposed: "health education" was reserved to efforts enhancing health among children, and occurring in the family and (pre)-school; "health information" for efforts aiming at adults through the media and for adult education, while "health counseling" was reserved for advilce to healthy and sick people given to them within the health care system (Von Tröschke \& Stossel, 1981). Phy'sicians' health counseling is directed at the individual patient and essentially consists of a comprehensive analysis of risk-and protective factors, aiming at mid-and longterm life planning (o.c.). However, the role of the physician in a coordinated comprehensive health care delivery system aiming at raising the heatth consciousness of the individual citizen has been insufficiently clarified. Nonetheless, physicians' professional responsibility for health education has been discussed and stressed regularly in Germany (Meinhardt, 1977; Göpel, 1979; Kissel, 1981; Junghans, 1982).

The content as well as the tone of the discussion on physicians role in heatth education has changed over the years. This change has been inspired by a growing realism among physicians with regard to their contribution to health education as well as by the striving for accountability found among professional health educators (Henderson $\&$ Mclntosh, 1981; Hislop, 1986). Two English literature reviews illustrate the change. Tyser (1975) concludes the general practitioner has a unique position for teaching health and the primary care team is an exceptional instrument for the improvement of the nation. This almost triumphalistic tone cannot be found anymore in the much more down-to-earth line of thinking that characterizes Calnan and Johnson's more recent review. They question the evidence on the generall practice as the most amenable settings for health education, on general practitioners' effectiveness as health educator, and on the desilrability of their involvement in health education. Their conclusion is that though there is some ovidence that general practitioners can be effective health educators, for instance with regard to smoking cessation, much evaluative research remains to be done, especially observational studies into general practitioners' health education performance and comparative study into other health workers' health education performance (Calnan \& Johnson, 1983).

\subsubsection{Physiclan's health education in the Netherlands}

Health education has got impetus primarily more through other health workers than through general practitioners in Holland (Editorial Huisarts \& Wetenschap, 1976). In a broad analysis of the (im)possibilities of the general practitioner as health promotor, Van 
Es depicted this role as a modest role in which the physician should counteract the sacralization of the profession and focus on the prevention of too easy acceptation of the patient role: "Health is finally determined by society as a whole, and its change in the end is a polltical matter (Van Es, 1976, p.31). Analysing the pros and cons of general practitioners fulfilling preventive tasks, Van Aalderen and Knottnerus conclude that general practitioners should fulfil a central role in prevention in primary health care, because of the unique position of the general practitioner "the greater population"s participation due to the trust in the general practitioner, and because of the knowledge the general practitioner has of the environment and the population. Only the general practitioner can coordinate early detection and treatment. Prevention through the general practitioner guarantees a personalized approach the patient not being considered as a conglomerate of organ-systems. The obstacles to physician health education mentioned earlier in this paragraph by Campbell and Valente, among others, are found in the Netherlands also. The "anticipating medicine"-strategie (Van den Dool, 1977) is seen as only partly feasible (Van Aalderen \& Knotnerus, 1978). The Royal Dutch College of Physicians produced its Report on Health Education stressing a limited role for the physician in health education. This was already discussed in paragraph 1.4 (KNMG, 1979). In 1982, the National Association of General Practitioners outlined the basic tasks of the general practitioner. Health education tasks were listed succinctly; prevention of unjustified dependency on professional care, attention for adequate information were mentioned while collective prevention activities were not mentioned (Landelijke Huisartsen Vereniging, 1982). The physician should play an active role in health education, providing Information on healthful lifestyles, to be chosen as a part of one's. personal responsibility (Van der Does, $1981 \mathrm{a}$ and 1981b).

\subsubsection{Role performance, role expectations}

In comparison with the vast speculative and/or persuasive literature on physicians' health educational role, the empiricall literature is quite restricted. In Florida Panhandle (USA) a group of primary care physicians $(N=230$; response rate $=45 \%)$ was surveyed on their opinions on health education. The majority appeared to be sceptical about the potential of community-based health education, blaming its alledged ineffectiveness on the public's apathy and/or on health care system's inadequacy. A sizeable minority " however, was willing to begin with or increase their involvement in health oducation. Most physicians ranked their profession first when asked to whom the primary responsibility for Health Education should be assigned (Ford \& Ford, 1983). The patients' expectations to receive health counselling from the physicians are not yet of great Influence on them (Clearie, Blair \& Ward; 1982; Wallace \& Haines, 1984). In a survey on the physician's role in health promotion among a stratified random sample of Massachusetts physicians $(N=641$; response rate $=76 \%$ ), a majority considered elimination of cigarette smoking, avoidance of excess calories, knowledge of drugs and balanced nutrition first ranking health promotion items. Their involvement in health promotion assessed by routinely gathering intormation from patients on smoking. alcohol, drugs, stress, exercise and diet, appeared to be spread between $97 \%$ (one item counseling) and $27 \%$ (counseling with regard to all items). Three quarters of Massachusetts physicians agreod that it was definitely a physician's responsibility to educate patients about each of these risk factors (Wechsler, Levine, Idellson "Rohman \& Taylor, 1983). 
Valente et all in a survey ( $N=1040$, response rate $=65 \%)$ on health promotion among Maryland physicians found that $97 \%$ believed they should modify patients behavior to minimize risk factors. As appeared, their current success rates, varying between 3 and $5 \%$ might be increased by a factor 5 or 6 , if adequate support could be provided (Valente, Soball, Muncie, Levine \& Antlitz, 1986).

In Belgium, $60 \%$ of the general practitioners said to be involved in any health education activity, whereas $40 \%$ were not. These activities were largely in the field of secondary and tertiary prevention. Primary prevention is seen to be a responsibility of the family, the school and the media, general practitioners offering internships to the University of Gent's general practitioner-trainees were found to spend $16 \%$ of their time of health education, $15 \%$ to prewention and $69 \%$ to curative aspects of their work $(\mathrm{Ne}=104)$ (De Maeseneer \& Maes, 1982).

Foets et al., at the level of medical services utilization, found that $3.6 \%$ of the medical consumption was in the prevention area (Foets, Berghmans \& Janssens, 1985).

In the Netherlands, health education activities started in health centers primarily (Schachtschabel, 1980). Recently, a survey of patient education practices carried out among 52 general practitioners (response rate $47 \%$ ) showed that general practitioners consider patient education to be a central task periormance, but the range of methods they are willing to use is quite limited. General practitioners have no clear lidea about patient information needs (Spronck \& Warmenhoven, 1984). In an analysis of the general practitioners task performance, $5 \%$ of the time appeared to be used for prevention, operationalized as contraception, perinatal care, vaccination, health education, checkup, and surveillance. The time allotted by Dutch general practitioners to health education only was $0.1 \%$ (Boots, 1983; Van Zutphen, 1984).

On the basis of the analysis of 2517 doctor-patient encounters by 55 general practitioners - not representative for the Dutch general practitioner-population - Verhaak concluded that providing education takes time and does not occur very frequently. It appeared that thase complaints which involved education, were not very timeconsuming. More time-consuming complaints i.e. psycho-social problems tend to be treated by the Dutch general practitioners in the study, without education (Verhaak, 1986). In another paper Verhaak reports the analysis of 550 video-taped doctor-patient encounters with regard to the type of interaction. He concludes that heralth education only plays a minor and secondary role in the work of Dutch general practitioners. Very seldom health education materials are used. In only $7 \%$ of the encouters basic knowledge about the illness concerned was shared with the patient. Life-style aspects, i. $\theta$. smoking, eating habits and stress reduction were discussed slightly more frequently (Verhaak \& Van Busschback, 1987).

\subsection{Discussion}

The conceptualization of health education in the literature was reviewed. As was shown already in 1.1, a number of definitions of health education have been proposed by health education theoreticians of different cultural backgrounds. Common elements considered to be essential for health education were the establishment of a relationship between 
health and behavior, the treedom of personal choice, the participation of lay people and the systematic application of change efforts. Parsimony is not a major trait of most health education definitions. It is the merit of Green and colleagues to have given a clear and operationalized definition of health education. It is not wordy, and does not contain overstatements which have become usual in WHO terminology. Criteria for application and assessment are provided. For these reasons this researcher feels most comfortable with Green's conceptualization of health education (Green et al., 1980).

The concept of health education among schoolteachers reflects the high expectations existing with regard to health education. Recent developments and discussions in the Netherlands show that a critical consciousness on the potential of health education has grown; discussions on scope and identity are flourishing still. It is striking that both in the American (Kolbe \& Iverson, 1980; Bensley, 1985) and in the Dutch literature (Hegger, 1979a; Hansson \& Visser, 1984), the role of the teachers does not get much attention. Especially in the situation when expectations with regard to health education are as high as they are among its defenders, it is not quite logical to oversee the crucial role of the teaching professional. Actually, the school system, after years of (over)enthusiastic innovations in many respects, is confronted with retrenchments. Applying the "last in, first out" principle, many young teachers will never be in the position to work on school health education. The climate is far from ready for innovations except with regard to the use of computers, as has been observed by the president of the Dutch Union for Health Education (Wams, 1986). The need of coordination of school health education activities has been expressed (Hansson \& Visser, 1984; Jones, Ellis, Fopeano et al., 1984; Panis, Veerman \& Van Kesteren, 1985; Bensley, 1985). This need, obviously contrary to "upstream" health education conceptions, might create tension at the local level (Van Beilen \& Faber, 1986).

In the nursing profession, some authors expressed very high requirements with regard to the profession itself. The nursing profession claims a role in health education, but shows discontent about the practice of nurses' health educational activities. Moreover, the public does not always consider the nurses as a credible source for health information (Knopf-Elkind, 1980; Bullough, 1981). Physicians, on the contrary, are considered to be credible sources to a much larger extent (David, 1980). Both nurses' and physicians' role in health education is a much debated issue in the international literature. In the Netherlands health education is integrated in community nurses' practice; the scarce research shows that it is difficult to achieve accountability for health education efforts in the community nursing setting. Dutch physicians produced a position paper on physicians' role in health education, outlining a clear and balanced role for the physician and explicitely assigning other role aspects to other health professionals. In the role delineation of the general practitioner, much less operationalized statements on information and education by the general practitioner were produced. The scarce research indicates that there is a limited understanding of the health education methods avialable and a more limited application of these.

The methods used to clarify and analyse key health professionals' role in health education are mostly Delphi-like reiterative processes aiming at creating consensus within the protessional group on role delineation, or surveys among samples of convenience asking professionals' opinions in an unstructured way or by means of instruments within unknown validity and reliability. This type of consensus building 
involving many professionals might be time-consuming, but it is obviously necessary to develop a view on such a vital issue as is the profession's own role in the care for health. It can be productive if clearly structured, with regard to content and time schedule, but does not necessarily improve delivery unless adequate implementation is being safeguarded.

In this phase of development of health education, prestructured surveys using valid and reliable instruments carried out among representative samples of professionals still can provide useful information. Furthermore, reviews and meta-analyses of the results will enable the professions to develop realistic roles in health education for themselves.

\subsection{Conclusions}

1. Green et al's conceptualization of health education operationalized by the PRECEDE/PROCEDE framework is a useful basis for further analysis.

2. In the netherlands, the conceptualization of health education has been less explicit than it has been in the anglo-saxon countries because of the interwovenness of health education in the provision of primary health care. The current situation with regard to health education in the Netherlands can be characterized as a promising backlash.

3. Both in the Dutch and in the international literature, studies on role expectations and role performance have been scarce. Some reviews indicate that expectations with regard to health education carried out by key health professionals became more realistic.

\subsection{Summary}

In this chapter the literature on the conceptualization of health education is reviewed with special attention for conceptualizations from the fields of teaching, nursing and general practice. In the framework of health promotion, health education is considered to be a crucial tool. In teaching, the way health education is conceptualized is dominated by major American projects like the school health education study and more recently, the growing healthy curriculum. In the Netherlands, the school health education project of Nijmegen was implemented on a nationwide level. The Amsterdam school health education project, using a bottom-up strategy, was implemented on a local level. Recent legislation brought official status to school health education in the netherlands. The role of the teacher in health education is concoived in a variety of ways, mostly focusing on health attitudes. Taking into account output measures in other disciplines than health, has given a new perspective on effective introduction and maintenance of school health education programs.

In the nursing field, health education has always been seen as a generic task. Due to organizational and professional barriers, its development only led to partially effective conceptualization of health education. Nursing theoreticians claim a crucial role in health education and prevention for the nurse. In the Netherlands too, health education has been part and parcel of the community nurses" task since several decades. The Dutch National Cross Union, employing virtually all dutch community nurses, has been in the 
forefront of the development of health education in the country. Recently, further growth of their involvement in health education and prevention has been planned by creating the capacity of the so-called local health educator. Studies of the role of the community nurse showed that major obstacles to a more beneficial fulfilment of the health education task of the Dutch community nurse, are time restraints and coardination/ collaboration with other relevant sectors inside and outside the health care system.

Among physicians, there appeared to be several ways of conceptualizing health education varying from predominantly pedagogical in nature to a reductionist technical behavioral modification approach. Some physicians completely decline their responsibility for the patient's health behavior. Most physicians pleading for health education range a wide variety of health-directed and -related behaviors within the medical domain. Formalization of health educational aspects in task descriptions only took place over the last decade. On the whole, role performance of the Dutch physicians in the field of health education is difficult to assess. Further clarification of key health professionals' tasks in health oducation is needed. 


\section{References}

Van Aalderen, H.J., Knottnerus, J.A. 1978. Is de huisarts in staat preventieve taken op zich te nemen? Huisarts en Wetenschap 21, 424-427. (Can the family physician assume prevention tasks?)

Van den Akker, A.M.E.A. Visser, A.Ph., 1984. Ervaringen met gezondheidsedukatie in het Amsterdamse basisonderwi]s. Vrije Universiteit Amsterdam / Buro GVO, Amsterdam. (Experiences in Amsterdam elementary schools).

Aujoulat, L.P., 1966. Health Education what does the general practitioner think? International Joumal of Health Education, 9, $170-178$.

Backett, E.M., 1981. Health Education training for physicians. In: Recht, P. 0.c., 163-172.

Bartlet ${ }_{8}$ E.E., 1981. The contribution of school health education to community health promotion: what can be reasonably expect? American Joumal of Public Health, 12, 1384-1391.

Beilen, E. van, Boelhouwer, J., Faber, S.J., Muller, J.M., 1986. Lokale GVO:

Gezondheidsvoorlichting en -Opvoeding als antwoord op vragen van de bevolking.

Deel 1: Algemeen overzicht

Deel 2: Vraag en aanbod

Doel 3: Groepsvoorlichting

Deel 4: Programmering

Deel 5: De lokale organisatie

Deel 6: Funktieprofiel

Deel 7: Beleidsontwikkeling

(Local health education as a response to local communities' demands (7 parts)).

Andragogisch Instituut, Fijksuniversiteit Groningen.

Belgisch Rode Kruis, 1983. Onderzoek in de basisschool omtrent de begeleiding ivm. GVO bij leerkrachten, derde kleuterklas, eerste leerjaar en schooldirecties. Brussel. (Research into the health education introduced into elementary education among teachers and school boards).

Bensley, L.B..1986. School health education in the USA: the state of the art. Wilhelmina Rouwenhorst Lecture 1985. Supplement GVO \& Preventie: Het Basisonderwijs in Internationaal Perspectief, 11-17.

Boots, J.M.J., 1983. Het werk van de huisarts. Dissertation. University of Limburg, Maastricht. (The work of the general practitioner).

Brunton, S.A. 1984. Physicians as patient teachers. Western Journal of Medicine, 6, 855-860.

Bullough, B. 1981 . Nurrses as teachers and support persons for breast cancer patients. Cancer Nursing, 221 2225 .

Bultman, J. Kuiper, J.P., Dupon, C., Loon-Netjes, $W_{n, 1}$ 1982. Verplegen met de handen op de rug: de (on)mogelijkheden van zelizorg en mantelzorg zoals ervaren door wijkverpleegkundigen; een orifenterend onderzoek. Amsterdam Instituut voor Sociale Geneeksunde, Vrije Universiteit. (Nursing with hands on your back: (im)posisibilities of selfhelp and mutual aid as experienced by community nurses).

Calnan, M.W. Johnson, B.M., 1983. Influencing health behaviour: how signilicant is the general practitioner? Health Education Journal 2, 39-45. 
Campbell, J.L., Valente, C.M., 1983. Physician involvement in Health Education: needs, problems, solutions. Maryland State Medical Joumal, 4, 284-290.

Chartion, $A_{*}, 1981$. Healith Education and the teacher's role. Intemational Joumal of Health Education 2, 102-112.

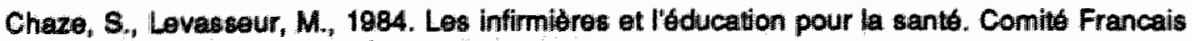
d'Education pour lia Sant6, Paris. (Nurses and health education).

Comillot, P., 1981. Concepts and alms of training in Health Education for general practitioner. In: Recht, $P_{1,}$, 0.C., 174-195.

Cotton, E., 1082. L"Education pour la sante: méthodes. Edi. Université de Bruxelles, Bruxelles. (Health education methods).

Clearie, A.F."Blair, S.N., Ward, W.B., 1982. The role of the physician in health promotion: findings from a community telephone survey. Journal of the South Carolina Medical Assocition; 9 , 503-505.

David, A.K, 1980. A study of preventive health attitudes and behaviors in a family practice setting. Joumal of Family Practice, 1, 77-84.

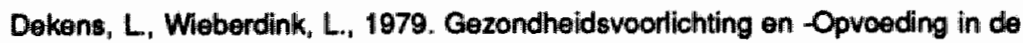
eerstelijnsgezondheidszorg. University of Groningen. Andragogisch Instituut. Thesis. (Health Education in primary care settings).

De Kok, F.A.C., 1986. Het effect van Gezondheidswoorllichting en -Opvoeding in het basisondenwijs. Katholleke Hogeschool Tilburg. (The effect of health education in elementairy schools).

Dismuke, S.E., Miller, S.T., 1983. Why not share the secrets of good health? The physician's role in health promotion. Journal of the American Medical Association, 249, 3181-3183.

Doeleman, F., 1959. Onderzoek naar de preventie: instelling van de wijkverpleegster. Katholieke Gezondheidszorg 28, 325. (Prevention investigated: community nurses' attitude).

Doelemen, F., 1961. De gezondheidsvoorlichting en -opvoeding op de lagere schooll. Tijdschrift voor Socialle Geneeskunde, december, 737-738. (Health education in elementary schools).

Van der Does, E., 1981a. The doctor and health inlormation and education. In: Recht,P. 37-50. o.c.

Van der Does, E., $1981 \mathrm{lb}$. De arts als gezondheidsvoorfichter. Medisch Contact 9 239-242. (Physicians as health educators).

Van der Dool, C.W.A., 1977. Anticiperende Geneeskunde. In: Gerligs, P.G., Birkenháger, W.H., Es, J.C. van. Het Medisch Jaar, Oostbook, Utrecht. (Anticipating medicine).

Draljer, J., 1985. De rol van de PABO. In: Symposiumverslag "Gezondheidseducatie doe je samen". Supplement GVO \& Preventie, 22-33. (The role of teacher training colleges).

Editorial Huisarts \& Wetenschap, 1976. GVO-deskundigen aan het woord. Huisarts \& Wotenschap $19,119-121$. (Health Education experts speak up).

Van Es, J.C., 1976. Mogelijkheden en onmogelijkheden van de huisarts als gezondheidsbevorderaar. Medisch Contact, 31, 1357-1363. ((Im)possibilities of the family physician as health promotor).

Evans, L.K., 1980. Health Education from a group perspective. Clinical Nursing 2,45-55. 
Faulkner, A. Ward, L., 1983. Nurses as health educators in relation to smoking. Nursing Times Occasional Paper, 79/8, $47-48$.

Fletcher, D.J., 1985. Building a pathway to better health: the primary care physician's role. Postgraduate Medicine, 1, 297-310.

Foets, M., Berghmans, F., Janssens, L., 1985. The primary helth care project in Belgium: a survey on the utillization of health services. Social Science \& Medicine, 20, 181-190.

Ford, A.S., Ford, W.S., 1983. Health Education and the primary care physician: the general practitioner's perspective. Social Sclience and Medicine, 17, 1505-1512.

Fortias, ل. 1980. Reflexions sur le rôle pédagogique de linfirmiêre. Soins 5, 49-54. (Reflections on the educational role of the nurses).

Fréour, P., 1980. La mission éducative du médecin dans la défense de la santé. Bulletin de l'Académie Nationale de Médecine, 7,644-648. (The educational task of the physician for health protection).

Van Geffen, B., Hegger, W., Voragen, A., 1985. Gezondheidskunde voor leraren basisonderwijs. deel 1. Introductie. Van Gorcum, Assen/Maastricht. (Health education for elementary schoolteachers).

Gerards, F.M., 1983. Geestelijke Gezondheidsvoorlichting en -Opvoeding in het onderwijs. Maandblad Geestelijke Volksgezondheid 9, 935-946. (Mental Health Education in schools).

Goldman, L., Pearson, C., Personal communication.

Göpel, E., 1979. Gesundheitserziehung oder Didaktik der Medizin? In:" Jahrbuch für kritische Medizin Bd. 4, Berlin. 42-55. (Health Education or didactics of medicine?).

Green, L.W., Iverson, D.C., 1982. School health education. Annual Review of Public Health, 3, 321-338.

Green, L.W. 1988. Effectiveness of health education: from theory to practice. Wilhelmina Rouwenhorst Lecture at the University of Maastricht. In press.

Hagendoorn, H., Verburg, H., 1981. GVO in de jaren tachtig. GVO \& Preventie, 2, 5-13. (Health education in the 1980's).

Van Hameren, J., 1980. Gezandheidsvoorlichting en -Opvoeding op school: coordinatie van de nationale gezondheids- en onderwijspolitiek. In: Vuylsteek, K, Maes, L. (Eds.) Gezondheidsvoorlichting en -Opvoeding in de school: problemen en oplossingen. WHO Euro Symposium, Gent, p.71-80. (School Health Education: coordination of national health and education policy).

Hansson, P., Visser, A.Ph., 1980. De introduktie van Gezondheidsvoorlichting en -Opvoeding in het Amsterdamse basisonderwijs. Deel I. Interimrapport over het onderzoek. Vakgroep Sociale Psychologie, Vrije Universiteit Amsterdam en Buro Gezondheidsvoorlichting en Opwoeding. Amsterdam. (Introduction of health education in Amsterdam elementary schools: internal report).

Hansson, P., Visser, A.Ph., 1981a. De introduktie van Gezondheidsvoorlichting on -Opvoeding in het Amsterdamse basisonderwijs. Deel III. Het onderzoek onder onderwilsgevenden. Vakgroep Sociale Psychologie, Vrije Universiteit Amsterdam en buro Gezondheidsvoortichting en -Opvoeding. Amsterdam. (Introduction of Health Education in Amsterdam elementary schools; teachers.' responses). 
Hansson, P., Visser, A.Ph., 19816. De introduktie van Gezondheidsvoorlichting on -Opvoeding in het Amsterdamse basisonderwilts. Deell IV. Het onderzoek onder overige doelgroepen (ABC-team, schoolbestuur, oudercommissie, schoolgezondheidszorg). Vakgroep Sociale Psychologie, Vrije Universiteit Amsterdam en Buro Gezondheidsvoorlichting en Opvoeding; Amsterdam. (Research among other target groups).

Hansson, P., Visser, A.Ph. 1981c. De introduktie van Gezondheidsvoorlichting on -Opvoeding in het Amsterdamse basisonderwijs. Deel V. Het onderzoek onder (nederlandstalige) ouders. Vakgroep Sociale Psychologie, Vrije Universiteit Amsterdam en Buro Gezondheidsvoorlichting on Opvoeding. Amsterdam. (Research among Diutch speaking parents).

Hansson, P., Visser, A.Ph., Haan, M.C.A. den 1981 . Onderzoek over de introductie van Gezondheidswoorlichting en -Opvoeding in het basisonderwijs. Gezondheid en Samenleving 2, 168-169. (Research on the introduction of Health Education in elementary education).

Hansson, P., Visser, A.Ph., (Eds.). 1984. Gezondheidsedukatie in het basisonderwijs. Van Gorcum, Assen. (Health education in elementary schools).

Hattinga Verschure, 1979. Mantelzorg. Medisch Contact, 34, 139. (Lay care).

Hegger, W., 1979a. Onderwijs in gezondheid: Leerstofstrukturering bij Gezondheidswoorlichting en - Opvoeding. Jeugd en Samenleving, 428-442. (School health education curriculum planning).

Hegger, W., 1979b. Op je gezondheid. Algemene Inleiding GVO in het basisonderwijs (4- tot 12jarigen). Wolters-Noordhoff, Groningen. (On your health: general introduction to elementary school Health Education).

Hegger, W., 1980. Gezondheidskunde in de lerarenopleiding voor het basisondenwijs. Advies Commissie Lager Onderwijs inzake Gezondheidskunde en Omgangskunde. Enschede. (Health Education in teacher training).

Hegger, W., 1982. Jeugdgezondheidszorg en GVO. In: Congresboek Gezondheidsvoorlichting en Opvoeding. Capaciteitsgroep Gezondheidsvoorlichting en -Opvoeding, Rijksuniversiteit Limburg, Maastricht, 201-205. (Youth health care and Health Education).

Hegger, W. (Ed.), 1986. De invoering van GVO in het basisonderwijs en de PABO: een inventarisatie. Deel $8:$ Studiekonferentie tot 1985. Hoogveld Instituut, Nijmegen. (The introduction of health education in elementary schools and teacher training colleges. Conference Report, Part 8,1985 ):

Hegger, W.G., Hameren, J.A.M. van, 1982. Gezondheidswoorlichting en -Opvoeding in het onderwijs. Het eindadvies van de Kommissie Nationaal Plan GVO. Deel $V_{\text {in }}$ Staatsuitgeverli, "s-Gravenhage. (Health Education in schools, Final report to the Committee National Plan for Health Education).

Henderson, A. C., Mcintosh, D.V., 1981. Role-refinement and verification for entry-level health oducators. National Center for Health Education, San Francisco.

Heyerick, J.P., Maes, L., De Maeseneer, J., et al., 1981. Gezondheid, je kunt er zell wat aan doen. Diensitien van de Eerste Minister Wetenschapsbeleid, Brussel. (Health, a personal responsibility).

Hislop ${ }_{10}$ M.E ${ }_{*}$ 1986. Health Education: a separate discipline? Health Promotion (Can.), 33, 6-9. 
Hoste, R. 1979. Practitioners' perceptions of professional health education training for teachers. In: Billington, D.R., Bell, J., Gass, M. et all: (Eds.) Research in Health Education. Dunde日, 32-33.

Johannesma, J.C.M. "1982. Patientenvoorlichting, en aktueel onderwerp. Tijdschrift voor Ziekenverpleging, 35, 3,79-82. (Patient education, a timely subject).

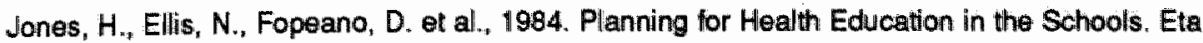
Sigma Gamma, Monograph Series no. 1.

Junghans, G. 1982. Praevention, Aufgabe des Hausarztes. Allgemein Medizin 2, 100-103. (Prevention, task of the familly doctor).

Karenko, E.N., 1984. Sov. Zdra Vookhranenie 8, 37-40.

Kissel, D., 1981. Der Arzt und die Erziehung zur Gesundheit. Mänch. Medizinisches Wochenschrift, 7,61-66. (The physician and Health Education).

Kleiterp, L., 1954. De mogelijkheid van volksgezondheidswoorlichting op de scholen. Groene \& Witte Kruis, 46, 172-179. (The possibility of public health education in schools).

Knapen, M.H.J.M., Scheffer, W.C.M., Hutjes, J.M., 1976. Patient, wijkverpleegster en huisarts, hoo zien ze elkaar? Tjeenk Willink, Groningen. (Patient, community nurse and general practitioner, mutual perceptions).

KNMG Studiecommissie Gezondheidsbevordering, 1979. Riapport Gezondheidsbevordering. Medisch Contact 6, 188-194. (Report on health promotion).

Knopt-Elkind, 1980. Nurses' smoking behavior: review and implications. Intermational Joumal of Nursing Studies, 17, 261-269.

Kolbe, LJ., 1982. What can we expect from school health education? Journal of School Health 3 , 1.45-150.

Kolbe, L.J., Iverson, D.C., 1980. Research in school health education, a needs assessment. Health Education 1, 3-8.

Kolbe, L.J., Iverson, D.C., 1981. Implementing comprehensive school health education. National Center for Health Education, San Francisco.

Koski, A. 1978. A national study of administrative and curricular practices of Departments of Health. Health Education and Health Science. Department of Health, Oregon State University, Corvallis.

Lagerwaard, D., Visser, A.Ph., 1981. De introductio wan Gezondheidsvoorlichting on -Opvoeding in thet Amsterdamse basisonderwijs. Deel II. Het onderzoek onder de ouders van buitenlandse en anderstalige kinderen. Vakgroep Sociale Psychology, Vrije Universiteit Amsterdam. (Introduction of health education in Amsterdam elementary schools: immigrant parents" and childrens" viows).

Landelijke Huisartsen Vereniging, 1982. Basistakenpakket van de huisarts, Utrecht. (Basic tasks of the general practitioner).

Lamberts, H., 1981. Patientenvoorlichting: een heel gewoon onderdeel van de geneeskunde. Huisarts en Wetenschap 24, 263-268. (Patient education; a basic part of medicine).

Lewis, H.L. 1978. Nurse practitioners in prewention and Health Education. Hospital Progress 59, 80-83. 
Maes, L., 1985. Gezondheidsvoorlichting on Opvoeding. In. Gids voor hel basisondenwijs. CED. Samsomis Brussel, 1985. (Health Education).

De Maeseneer, J., Maes, L., 1982. Gezondheidsvoorlichting en -Opvoeding in de Vlaamse huisartsenpraktijk Gezondheid en Samenleving 3, 133-140. (Health Education in Flemish general practice).

Mason, J.O., Tolsma, D.D., 1984. Personal health promotion. Western Jounal of Medicine, 141, $772-776$

Moinhard, J., 1977. Der Arzt als Padagoge. Deutsches Aerzteblatt 36, 2177-2180. (The physician as a pedagogue).

Mertens, C., 1983. Ontwikkelingen in het werk van de wijkverpleogkun dige. Verpleogkundige Studies 46. De Tijdstroom, Lochem-Poperinge. (Developments in community nursing).

Morgan, $P ., 1980$. Health Education and risk assessment: a new role for physicians in primary prevention. Canadian Medical Assocication Jounal, 12, 623-626.

Muskens, G.J.i 1984. Wijkverpleging en GVO: inventarisatie in acht basiseenheden. MA, Tilburg. (Community nursing and Health Education: inventoriating study in eight units).

Nationale Kruisvereniging, 1986. Kruiswerk en Gezondheidsvoorlichting en -Opvoeding: nieuwe trends. Een beleidsschets over Gezondheidsvoorlichting en LOpvoeding vanuit het kruiswerk. Bunnik. (The National cross and Health Education: new trends).

Nutbeam, D., 1986. Health promotion glossary. Health Promotion, an Intemational Joumal $1,113-$ 127.

Nutting, P.A., 1986. Health promotion in medical care: problems and potention. Preventive Medicine, 15, 537-548.

Olsen L.K., Redican, K.J., Krus, P.,H., 1980. The school health curriculum project: a review of research studies. Health Education 1, 16-21.

Panis, A.E.L.M., Veerman, J., Kesteren, E.J. van, 1985. De invoering van Gezondheidswoorlichting en -Opvoeding in het basisonderwijs en de PABO: een inventarisatie. deel I: Onderzoek onder 30 basisscholen. Hoogveld Instituut, Nijmegen. (The introduction of Health Education in 30 olementary schools).

Parcel, G.S., 1984. Theoretical models for application in school health education research. Journal of School Health Education $54,6,39-49$.

Pender, M.J., 1982. Health promotion in nursing practice. Appleton-Century Crofts, London.

Perry, C.L., 1984. A conceptual approach to school-based health promotion. Journal of School Health, 54, 6, 33-38.

President's Committee on Health Education, Taksforce on Patient Education, 1974. The concept on planned, hospital-based patient education programs. Health Education Monographs, 2, $1-10$.

Puska, P. Neittaanmaki L., 1979. Health professionals as educators, experiences from the North Karelia project. In Ramstrom, L.M. (Ed.) The smoking epidemic. Amqvist and Wicksell, 263-266.

Recht, P. (Ed), 1981. The role of the physician in Health Education. Commission European Community, Brussels, Luxembourg. 
Rouwenhorst, W., 1977. Leren gezond te zijn? Over de plaats en mogelijkheden van Gezondheidswoorlichting en -Opwoeding in de zorg voor gezondheid. Samsom, Alphen a.d. Rijn. (Leaming to be healthy; on the possibilities of health educetion in the care for health).

Ruiter, B., 1982. Gezondheidsvoorlichting en -Opvoeding in het werk van de wijkverploegkundige. In: Congresboek Gezondheidsvoorlichting en -Opvoeding. Capaciteitsgroep Gezondheidswoorlichting en -Opvoeding, Rijksuniversiteit Limburg, Maastricht p.120-126. (Health Education in community nursing).

Saris, W.H.M., Binkhorst, R.A., Cramwinckel, A.B., Hegger, W.G., Konig, K.G., 1982. The development of a health education program for school children. Tijdschrift voor Sociale Ceneeskunde, 22, 680-684.

Schachtschabel, H., 1980. Gezondheidswoorlichting en -Opvoeding in het klein: een verslag over de GVO-aktiviteiten van het gezondheidscentrum Osdorp. Tijoschrift voor Sociale Geneeskunde 19,693-696. Health education at the local level: a report on health education activities in the Health Center of Osdorp. Amsterdam).

Selivanov, A.P., Zaplatnikov, L.T., Smolenskaya, I.K., Pitskovskaya, A.A., Tsjagorets, L.V., 1986. Podgotovka studentov $k$ gigienitsjeskomu vospitaniyu shkoljnikow $v$ meditsinskikh i pedagogitsjeskiv vuzakh. Sov. Zdravoochr. 8, 52-56. (Teacher preparations for health education).

Sieres, J., Soriano, J., 1984. De la salud del escollar en Espagna; de la funcion del maestro en la protection. Hygie International Journal for Health Education, 4, 32-34. (On school health education in Spain: the role of the teacher in lhealth maintenance).

Simonds, S.K., 1977. Health Education today: issues and challenges. Joumal of School Health, $12,584-593$.

Simonds, S.K. Nijhuis, F., DiPietro, R., Adriaanse, H., 1984. International Statement of Competencies for health educators. ELC Consortium, Maastricht/Ann Arbor.

Simonds, S., Rouwenhorst, W. Adriaanse, H., Damoiseaux, V., Dubois, V., Saan, H. "1982. Exit level competencies for health education in the social health program at the Rijksuniversiteit Limburg, Maastricht.

Skrabanek, $P$., 1986. Preventive medicine and morality. Lancet, January 18th, 143-144.

Sliepcevich, E., 1967. Health Education: a conceptual approach to curriculum design. School of Health Education Study, Washington DC.

Smith, J.A. 1979. The challenge of Health Education for nurses in the 1980:. Journal of Advanced Nursingl, 4 $531-543$.

Smits-Van Sonsberk, B., Hegger, W., 1979. Op de gezondheid: Didaktische verantwoording. Gezondheidswoorlichting on -Opvoeding voor kleuters. Wolters-Noordhoff, Groningen. (To your health: teachers' guide)

Spronck, V.A.A., Warmenhoven, N.E., 1984. Patient education in general practice: opinions of general practitioners. Patient Education and Counseling, $2,68-75$.

Stone, D.B. Rubinson, L.G., 1979. The issue af school thealth education: theory and practica. Public Health Rev. 1, 45-79.

Teunissen, OM., 1981. School thealth in the Netherlands. ACLO Gezondheidskunde en Omgangskunde, Enschede. 
Von Tröschke, d., Stossel, U. (Eds.). 1981. Möglichketten und Grenzen artzlicher Gosundheidsberatung. Cesomed: Freiburg. (Possibilities and boundaries of physician Health Education).

Tyser, P.A ${ }_{*}$ 1975. Health Education in general medical practice. Health Education Journal, $35,3-$ 11.

US Dept. Health end Human Services, 1982. Guidelines for health promotion and education services in HMO's, Wasthington.

USDHEW/CDC, 1976. HEIAS: Thesaurus of Health Education terminology. School of Public Haalth Johns Hopkins, Baltimore.

Valente, C.M., Sobal, J., Muncie, H.L., Levine, D., Antiltz, A.M., 1986. Health promotion, physician's beliefs, attitudes and practices. American Journal of Preventive Medicine, 2, $82-88$.

Verhaak, P.F.M., 1986. Bewerkelijkheid van huisartsconsulten met verschillende klachten of patienten, uitgedrukt in tijd. Tijdschrift woor Sociale Gezondheidszorg, 17, 558-562. (Time spending in doctor-patient encounters treating different complaints and/or patients).

Verhaak, P.F.M. Busschback, J.T. van, 1987. Health education in general practice. Paper First European Conference Health Education, Madrid, 1987. Proceedings in press.

Verhoeven, J., Suetens, B., 1985. Gezondheidsopwoeding in het basisondenwijs, deel II en II. Een onderzoek naar kennis, houding en gebruik van GVO. Sociologisch Onderzoeksinstituut, Katholieke Universiteit Leuven. (Health oducation in elementary schools: an investigation into knowledge, attitudes and application of health education).

Visser, A.Ph. Hansson, p., May "J., 1984. De leerkrachten. In: Hansson, P., Visser, A.Ph., (Eds.). Gezondheidsedukatie in het basisonderwijs. Van Gorcum, Assen "p.42-51. (The teachers).

Visser, A.Ph., Lagerwaard, D., 1981. De ontwikkeling van Gezondheidsvoorlichting en Opvoeding-onderwijs voor kinderen van anderstalige ouders. Tijdschrift voor Sociale Geneeskunde 59, 812-817. (Development of School Health Education for non-Dutch speaking parents).

Wallace, P.G., Haines, A.P., 1984. General practitioner and health promotion. What patients think. British Medical Journal 289, 533-536.

Wams " H.W.A., 1985. Opening van het jaarthema (Gezondheildsedukatie). Symposiumverslag "Gezondheidseducatie doe je samen". Supplement GVO \& Preventie, 3-6. (Opening address: School Health Education Symposium).

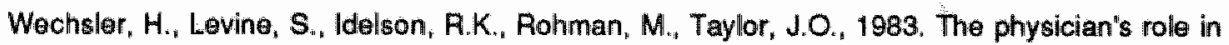
health promotion - a survey of primary care practitioners. New England Journal of Medicine 2. $97-100$.

Wiersma, Y., Suhre, C.J.M., 1987. Stand van zaken gezondheidseducatie: Eindrapport van het Project 'Gezondheidseducatie in het basisondenwijs', FION, Groningen. (School Health Education: state of the art).

World Health Organization, 1954. Health education of the Public. Technical Reports No. 89, Geneva.

World Health Organization/UNESCO Joint Expert Committee, 1960. Teacher preparation for health education. WHO Technical Report Series no. 193, WHO, Geneva. 
Wijnsma, P., 1986. Profilering en identiteit van gezondheidseducatie. GVO \& Preventie 1, 31-36, (Profile and identity of school health education).

Van Zutphen, W.M., 1984. De taken van de huisarts. Rijksuniwersiteit Limburg. Maastricht. Dissertation. (The tasks of the family physician). 


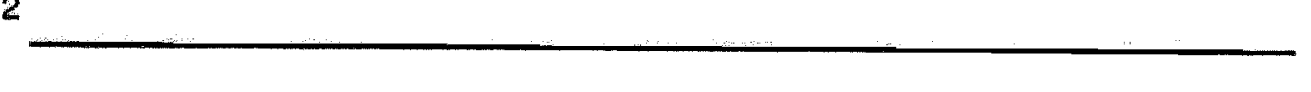




\section{Chapter 3. Health behavior}

3.1 Conceptualization

3.2 General health behavior

3.2.1 Atomistic conception of health behavior

3.2.2 Additive conception of health behavior

3.2.3 Scaling approach to health behavior

3.3 Research into key health professionals" health behavior

3.3.1 Health behavior in schoolteachers

3.3.2 Health behavior in community nurses

3.3.3 Health behavior in general practitioners

3.4 Discussion

3.5 Conclusion

3.6 Summary 


\section{Introduction}

The focus of this investigation is on the perception of health educational tasks, health behavior and the way key health professionals perceive an eventual exemplary role with regard to health vis à vis the general population. In this chapter the concept of health behavior is reviewed as well as the literature with regard to key health professionals' health behavior. As was the case for other subjects reported in other chapters, studies were located by regular computer searches in Medlars and Dimdi, by descendancy and ancestry and through contacts within the "invisible college", the informal professional network (Curlette \& Canella, 1985).

\subsection{Conceptualization}

It is no use to try to delineate once and for all the domain of health behavior. Health behavior can be defined only at a certain point in time for a circumscribed population. The conceptualization of health behavior shifts along the health-illnesss continuum; sometimes, it was defined exclusively in an illness-centered way, in a mixed way, or focussing on health only.

The term health behavior was coined by Kas| \& Cobb in 1966, who defined it as: 'any activity undertaken by a person believing hilmself to be healthy, for the purpose of preventing disease or detecting it in an asymptomatic stage'. Two types of individual health behaviors were distinguished: seeking regular health examinations to find out about one's health, and seeking to reduce the probability of future illness through immunization, prenatal care, etc. Behaviors to maintain or promote health such as exercising or dieting were expressis verbis excluded from their conceptualization of health behavior (KasI \& Cobb, 1966). Restriction of health behavior to the use of professional health services was applied also by Rosenstock, 1966, and Steele \& McBroom, 1972. Kasl \& Cobb's definition was amended by Langlie, who conceived preventive health behavior as: "any medically recommended action, voluntarily undertaken by a person who believes himself to be healthy, that tends to prevent disease or disability and/or detect disease in an asymptomatic stage' (Langlie, 1977).

In recent work by Calnan \& Rutter, preventive health practices chosen are firstly personal health procedures (use of seat belts, teeth brushing. breast self-examination, exercise, nutrition and smoking) and secondly the use of professional preventive health services of the dentist and the screening services for cervical smear and breast disease. Except for the relation between breast self-examination and smoking and teeth brushing, all nine preventive practices appeared to be significantly correlated. However, most correlations were modest, varying from .05 to .26 (Calnan \& Rutter, 1986).

It should be made clear at the outset that the notion of health behavior in the pertaining literature to be discussed, not only varies with regard to its operational context, but also with regard to the chosen terminology. While Kasl \& Cobb used the term "health behavior" without any adjective, others used specifications e.g. "preventive health behavior" (Green, 1968; Kristiansen, 1975; Steele \& McBroom, 1972; Rosenstock, 1974; Langlie, 1977). "protective health behavior " (Harris \& Guten, 1979), "health practices" (Belloc \& Breslow, 1972; Belloc, 1973; Calnan \& Rutter, 1986), "preventive health 
practices and procedures" (Pill \& Stott, 1985). The labels as well as the content of these notions are partly different, partly similar. In this text, the term "health behavior" is used to indicate all of the abovementioned notions, unless otherwise specified. In chapter 7 , heatth behavior is operationalized by ourselves; it is labelled general health behavior and measured by the health behavior index (see 7.3.3).

Some have advanced arguments against professional expert definitions of health behavior. A broader conception of Preventive Health Behavior (PHB) is proposed therefore: $\mathrm{PHB}$ includes a spectrum of actions undertaken by a person who believes himself to be healthy, ranging from voluntary exposure to health risks to active preventive efforts. (Nathanson, 1977). An even more non-medically defined health behavior conceptualization has been proposed by Harris \& Guten (1979). They argue that health behavior should not be defined professionally at all, but by the people themselves as a response to the question: "What do you do to protect your health?" Health Protective Behavior is defined as: 'Any behavior performed by a person, regardless of his or her perceived actual health status, in order to protect, promote or maintain his or her health whether or not such behavior is objectively effective to that end" (Harris \& Guten, 1979).

Little is known about the interrelationships between health behaviors. On reviewing the research on the co-occurrence of tobacco, alcohol and caffein consumption, listvan \& Matarazzo concluded that alcohol and tobacco use and tobacco and coffee consumption are strongly related. Calfein and alcohol use appeared to be weakly related. No studies encompassing the use of all three substances were found. No general theoretical models accounting for the interrelationships are presently available. Although the magnitude of the interrelationships between risktaking behaviors is small, the presence of reliable relationships among such diverse behaviors is striking (Istvan \& Matarazzo, 1984). Smoking appears to be negatively related to body mass index: smokers are leaner (Albanes, Jones, Micozzi \& Mattson, 1987) and to seatbelt use (Mechanic, 1979).

A very influential definition of health behavior stems from the Alameda County Study into health and ways of living, carried out by the Human Populations Laboratory (HPL) (Berkman \& Breslow, 1983). HPL started with an operationalization of WHO's health definition on the basis of the data of the Alameda County Study (Breslow, 1972). In the framework of this attempt to quantify "health", a number of common health practices ware selected to represent health behavior, on the basis of their relationship with physical health status and mortality (Belloc \& Breslow, 1972; Breslow \& Enstrom, 1980). HPL's Health Practices Index included physical activity, cigarette smoking, alcohol consumption, obesity, sleeping habits, eating breakfast and snacking between meals. In later research no ample attempts of verbal definitions are made, but quantitative operationalizations are given, specifying criteria for inclusion of certain health behaviors in the (dimensions of) the encompassing notion of health behavior (PIll \& Stott, 1985; Kristiansen, 1985). Three main lines of thinking are reviewed in the next paragraphs. 


\subsection{Three approaches of health behavior}

In investigations into health behavior, the points of view can be distinguished as follows:

1. Health behaviors have no - or weak - relationships among each other and should be analyzed separately: this position is labelled here as the atomistic approach of health behavior.

2. Health behaviors have in common a certain relation to morbidity and mortality, and to subjective health status; health behaviors have generalized health consequences and, therefore, an index can be calculated: this is labelled here as the additivity approach of health behavior.

3. For a certain group at a certain point in time domains of health behavior can be delineated, with sufficient internal consistency, allowing for one-, bi-, or multidimensional scalling of health behavior: the third position is labelled here as the scaling approach.

The atomistic, additivity and scaling approaches of health behavior are discussed in the following sections.

\subsubsection{The atomistlc conceptualization of health behavior}

On the basis of low interrelations between specific health behaviors, it is denied that health behavior as such can be considered in one category of behavior (Freeman \& Lambert, 1965; Green, 1970; Steele \& McBroom, 1972; Halfens, 1985). The range of health behaviors used by experts and/or reported by respondents is large. Health behaviors included: proper diet, bathing, weight control, teeth brushing, obtaining chest $X$-rays, ways of voting on fluoridation, wearing protective gloves at work, praying , and many more items. Thus it is not surprising that health behavior is not unidimensional. According to Steele \& McBroom, different groups of people use different criteria to delineate what health behavior is: the domain and the dimensionality vary according to the criteria used. They do not specify the number of dimensions of health behavior: therefore their argument runs down to an atomistic conceptualization of health behavior (Steele \& McBroom, 1972).

In a number of studies into health behavior the focus is on risk factors related to a specific disease, without addressing the correlations among these variables. In that type of study thealth behavior is not clearly conceptualized with regard to its dimensionality. However, an additive conceptualization (see paragraph 3.2.2) is assumed (e.g. Aro, Fasanen \& Telama, 1986). In their ten-year follow-up study study on health behavior in Finland, health behavior was operationalized by smoking, drinking, use of fat, sugar consumption in coffee and leisure-time physical activity (Aro et al., 1986).

\subsubsection{The additlve conceptuallzation of health behavlor}

On the basis of a relationship of health behavior to physical health status and mortality, it is argued that each health practice represents a contribution to diminishing the risk of endangering an individual's health and thus to longevity. Common health practices as hours of sleep, regularity of meals, exercise, smoking, drinking and weight for height 
constitute together the Health Practices Index (HPI). These practices were shown to be related to positive health in a cumulative sense: following more good health practices meant better health, independent from age, gender, and socio-economic status (Belloc \& Breslow, 1972). Quality of social networks was shown to be related independently to mortality (Berkman \& Syme, 1979). The relationship of HPI to mortality persisted over a nine year period (Breslow \& Enstrom, 1980). Smoking, excessive alcohol consumption, lack of physical activity, sleeping less than seven or more than nine hours, improper weight and irregularity of meals were found to be contributing to the mortality risk of adults. Irregular breakfasting did not increase relative risk (Wingard, Berkman \& Brand, 1979).

Belloc \& Breslow's HPI was used frequently in other studies. A five-point HPI was used by Gottlieb \& Green (1984) who found no significant association between HPI and health status, when social networks, life-events and demographic variables were controlled. The strength of the associations, and their temporal sequence as reported by Berkman \& Breslow, however, suggest that there is a relationship between good health practices, a strong social network and prolonged longevity (Berkman \& Breslow, 1983).

In an American study of students' health behavior including meal regularity, hard drug use, alcohol consumption, smoking, exercise and hours of sleep, it appeared that harddrug use, alcohol, and tobacco consumption constituted a common factor "drugs use". Meal regularity was slightly negatively related, while exercise and hours of sleep were not related to the common factor (Hays, Stacy \& DiMatteo, 1984).

Another Index - the Positive Health Behavior Index - was developed by Mechanic; his PHB-Index included risk-taking, being prepared for health emergencies, alcohol, smoking, seat-belt use, preventive (medical and dental) check-ups, physical activity and excercise. Internal correlations between behaviors were modest where present. The PHB-Index correlated moderately with other relevant health care orientations like trust in doctors, PHB is concluded to be part of a wider life style (Mechanic \& Cleary, 1980).

The line of reasoning of the Human Populations Laboratory was followed in a Belgian study on health behavior ( $N=1797$ ), in which a health behavior index was calculated on the basis of tobacco- and alcohol consumption-, drug-, stress-, nutrition-, and dental health scores. Intercorrelations were up only 10.16, one third being non significant. Smoking showed the strongest correlations with all other health behaviors. Two thirds of the population appeared to have a (rather) healthy life style (Dooghe, VandenBoer \& Van Loon, 1984). The same Human Populations Laboralory arguments brought Halfens to the opposite conclusion. He decided it was not suitable to use a health behavior sumscore because in his study into Locus of Control and health and illness behavior (N = 710): the focus was not on the rolationship between health status and health behavior (Hallens, 1985).

In the Nijmegen (NL) Health Project, focusing on thess behavior of the individual respondent $(N=1649)$ overtime, preventive health behavior was measured as a sumscors of: (in decreasing order of agreement) listening/watching health programs on radio and/or tolevision, dental check-ups, reading health magazines, non-smoking. exercise, buying health foods, abstention of alcohol, vegetarian eating habits, practising macrobiotics. This sumscore was assumed to represent the extent to which an individual intentionally pertorms health behavior (Furer, Tax, Heyendaal, Konig-Zahn \& Persoon, 1987 . 


\subsubsection{The scaling approach of health behavior}

In attempts to construct scales on the basis of a researcher-defined or lay-defined set of health behavioral items, Internal consistency is calculated by means of Cronbach's alpha. Scalle construction attempts have resulted in unidimensional health behavior scales (Kristiansen \& Harding, 1984; Rajala, Honkala, Rimpelä \& Lammi, 1980) " inconclusive results as to PHB"s uni-, bi-, or multi-dimensionality (Calnan, 1985 ; Pill \& Stott, 1985), bi-dimensionall scales (Langlie, 1979) and multi-dimensional scalles Willams \& Wechsler, 1972; Harris \& Guten, 1979; Kannas, 1981; Williams \& Harnly, $1982)$.

\section{* Unidimensionality of health behavior}

Rosenstock's unidimensional conception of health behavior was restricted to the use of professional health services as defined by the researcher: it was the basis of the Health Bellef Model (Rosenstock, 1966). Kasl \& Cobb (1966) already had pronounced themselves on their assuption of multidimensionality of generall health behavior; just a few investigators pursued the idea of unidimensionality that had been critisized (Freeman and Lambert, 1965; Green, 1970). Nevertheless, some investigations have resulted in unidimensional conceptualization of general health behavior. Health habits connected with dental care were found to be strongly related: this pertained to physical activity, smoking, drinking and social intercourse in relation to toothbrushing (Rajala, Honkala, Rimpelä \& Lammi, 1980).

Selection for it being made on the basis of data from multiple samples, a 42 -item general health behavior scale, was constructed from a 143 -item pool, involving mental health, road-and home-safety, drinking, nutrition, dental care, medical care, work and hygiene (Kristlansen \& Harding, 1984). Based on statisticall criteria, their scale excluded smoking. exercise, physical activity, breakfasting and hours of sleep. As had been reported by many other researchers inter-item correlations were low, but item-total correlations were high, the main of the alpha's across eight applications of Kristiansen \& Harding's general health behavior-scale being .82. In another study, however, carried out among the general population in Exeter (UK) $(N-340 ; R R=37 \%)$ analyzing the value correlates of personal health behavior on the basis of earlier literature, Kristiansen operationalized health behavior differently from what would be required in her previously mentioned Investigation. All Human Population laboratory's HPl-items were included there, except lor breakfast and snacking between meals (Kristiansen, 1985).

Inconclusive results with regard to general health behavior's dimensionality were reported also. Restricted support for the unidimensionality hypothesis was reported by Calnan (1985) who found all signiflicant but low correlations between breast- and cervical screaning, dental check-up, inutrition, exercise, smoking and seat-belt use among middle-aged women (three samples of about 1100 respondents, response rates 77 to $88 \%$ ). Using HPL-Health practices index among warking class women ( $\mathrm{N}=204$; $\mathrm{RR}=77 \%$ ), nor unidimensionality nor the existence of multiple independent dimensions could be shown (Pill \& Stott; 1985).

\section{" Multidimensional scaling of general health behavior}

Without attempting scale construction, Kasl \& Cobb (1966) already had pointed to the multidimensionality of general health behavior, stating that preventive health behavior 
could be of three kinds: illness detection in an asymptomatic stage $e_{n}$ future illness education and health promoting behaviors.

In two studies among suburban women ( $N=182 ; \mathrm{RR}=90 \%)$, and among high schoolers' parents ( $N=686 ; R R=63 \%$ ), there appeared to exist multiple, mostly independent dimensions within general health behavior, differing from one study to another (Williams \& Wechsler, 1972). Analyzing an urban populations" general health behavior in Rockford (Illinois) ( $\mathrm{N}=383 ; \mathrm{RR}=62 \%$ ), Langlie identified two dimensions of preventive health behavior (PHB): "indirect Risk PHB", a scale composed of indicators for seat-belt use, exercise, nutrition, medical check-ups, dental care, Immunizations and miscellaneous screening exams and secondly "Direct Risk PHB", a scale including driving, pedestrian behavior, personal hygiene and smoking (Langlie, 1977). She carried out an analysis of the interrelationships among health behaviors on the same material, in order to determine the dimensionality of general health behavior. Her hypothesis of bidimensionality was confirmed by later research (Langlie, 1979).

During a 12-year 'Normal health profile"-study ( $\mathrm{N}=616$; $\mathrm{RR}=\mathrm{NR}$ ), Williams \& Harnly developed four health habit scales: nutrition, alcohol, tobacco and physical activity to represent healthy functioning in addition to general well-being, medical events and psychological well-being as health status scales (Williams \& Harnly, 1982). Studying Cleveland's general population $(N=1250 ; R R=67 \%)$. Harris \& Guten started general health behavior scale construction by asking people what they did to protect their health. A health protective behavior set of variables was constructed on the basis of their responses. Cluster analysis revealed five dimensions called: 1. health practices (sleep, relaxation, nutrition, moderation, avoid overwork, avoid chills, limit focds, watch weight); 2. hazard avoidance (avoid crime and pollution); 3. safety (fix thingls, check condition, first aid kit, emergency phone numbers); 4. harmful substance avoidance (no smoking. no alcohol) and 5. preventive health care (physical and dental check-up) (Harris \& Guten, 1979).

The same number of dimensions, though different in nature, was found among Finnish young males ( $N=1546 ; R R=76 \%$ ). In his study carried out to determine whether health habits are cumulative in nature, Kannas found the following dimensions: 1. use of sugar and fat; 2. la dolce vita (use of alcohol, tobacco, drug trials, number of sexual partners); 3. active health-oriented behavior (physical activity, consumption of health information, breakfasting, use of reflectors); 4 , regularity of eating and resting habits and 5 . dental care. The smoking variable was the best predictor of health behavior in other areas and was concluded to be a key health habit. The total variance explained by the five dimensions was restricted to $28 \%$ only (Kannas, 1981 ).

In a factor-analytic study of health practices among patients of the University of Connecticut Health Center $\left(\mathrm{N}_{\mathrm{m}} 71\right)$, Tapp \& Goldenthal found three dimensions: "health promotional activities" (nutrition, exercise, rest, personal health), "avoidance of health risks" (no smoking, alcohol consumption, road- and water-satety), and "lack of awareness of good health practices" consisting of drug use, bad personal health (Tapp \& Goldenthal, 1982).

The delineation of the domain of general health behavior, the structure within that domain, as well as its determination have not been conceptualized unequivocally as yet. Though no accepted operational definition of general health behavior is avallable, HPL's 
Health Practices Index' items is part of the most of health behavior conceptualizations found in the literature "Kristiansen \& Harding's operationalization being a rigorous exception.

\subsection{Research into professionals' health behavior}

In the next sections the literature on teachers', nurses', and physicians' health behavior is summarized. These paragraphs are unbalanced due to the scattered availability of information on health professionais' health behavior. Literature on broad spectrum health behavior is scarce, as well as literature on other health habits than smoking and drinking. The literature on teachers", nurses' and physicians" tobacoo consumption was too vast to deal with here. Therefore, separate reviews have been made of the smoking habits of key health professionals (Adriaanse \& Van Reek, 1986; Adriaanse, Van Reek \& Evers, 1986; Adriaanse, Van Reek \& Van Zutphen, 1986). Hardly any comparative study was found, however, adolescents' health conceptions were found to differ from doctors', nurses' and teachers' views on health (Levenson, Morrow \& Pfefferbaum, 1984).

\subsubsection{School teachers' health behavior}

\section{* General health behavior}

In the framework of a nationwide survey on alcohol- and drugs-education in the Netherlands, carried out in 1986 among secondary schoolteachers ( $N=386 ; R R=51 \%$ ), Mesters also investigated their alcohol consumption, smoking behavior and use of drugs (Mesters, 1987).

\section{* Smoking}

The secondlary analysis of 38 investigations into teachers" smoking behavior in 19 countries showed that almost everywhere the majority of teachers is non-smoker. Smoking prevalences among teachers in different countries vary from 17 to $82 \%$ for male, from 3 to $41 \%$ for female teachers. In most countries smoking prevalences among male teachers were considerably higher than among female teachers. In general, teachers smoke less than their counterparts among the general population. Cessation rates among male teachers are higher than among the male population. Among Dutch teachers $(\mathrm{N}=122$; $\mathrm{RR}=\mathrm{B} 3 \%) 41 \%$ of the male, and $26 \%$ of the female teachers were current smokers in 1983 , while in the general population $44 \%$ of the males and $35 \%$ of the females were currently smoking (Adriaanse \& Van Reek, 1986).

In $1986,31 \%$ of the Dutch secondary schoolteachers were found to be current smokers, $23 \%$ had stopped and $46 \%$ had not smoked at all (Mesters, 1987 ).

\section{- Coffeo}

In a study into teachers' stress, carried out among Finnish teachers $(\mathrm{N}=187 ; \mathrm{RR}=\mathrm{NR})$, $90 \%$ of them used to drink coffee every day; $65 \%$ used up to five cups of coffee while $25 \%$ drank six cups of coffee and more per day (Kinnunen, Mäkinen \& Vihko, 1985). 


\section{* Alcohol}

About one fifth of the Finnish teachers appeared to be abstainers. Average consumption of alcohol was approximately one glass per day (Kinnunen et al, 1985). Amongst Flemish teachers, $24 \%$ were abstainers while $13 \%$ were daily, $34 \%$ were regular ${ }_{i}$ and $28 \%$ were occasional drinkers (Heyerick, Maes, De Maeseneer et al., 1981).

Twelve percent of the Dutch secondary schoolteachers were found to consume less than one alcoholic beverage per week, two thirds from one till ten glasses, while $21 \%$ drank more. Only three percent used over 26 glasses per weak (Mesters, 1987).

\section{"Nutrition}

Only $13 \%$ of Flemish teachers appeared to have good nutritional habits when asked about frequencies of consumption of vegetables, whole wheat bread, fat, milk and regularity of meals (Heyerick et al., 1981).

\section{- Exercise}

Half of Flemish teachers appeared to be engaged in active sports; $54 \%$ out of these spent up to five hours per week to their leisure-time sports (Heyerick et al., 1981).

\section{- Use of drugs}

Only seven percent of a nationwide sample ( $N=386 ; \mathrm{RR}=51 \%$ ) of Dutch secondary schoolteachers ever tried soft drugs. Five percent of the teachers has stopped, while only one percent continues to use soft drugs less than twice a week. Hardly any teacher ever tried any hard drug, i.e. cocaine, heroïne, pep or other stimulantia. None of the three percent of those, who ever tried, continued to use hard drugs (Mesters, 1987).

* About other health behaviors no data were available.

\subsubsection{Nurses' health behavlor}

According to Zahourek, a sizeable number of American nurses are so inflicted by addictions that they need help. Addictions comprise alcoholism, dependency on stimulants and tranquillizers. Nurses" smoking increased from 1969 to 1975 . Obesity is quite noticeable in nurses but not well documented. Burn-out due to stress is becoming more common (Zahourek, 1981).

In a sample of Alabama senior student nurses ( $N=555 ; \mathrm{RA}=32 \%)$ Rausch and colleagues found smoking nurses (prevalence $26 \%$ ) used breakfast less frequently and consumed more cups of coffee per day. No relationship appeared between between nurses' smoking and having regular exercise (Rausch, Zimmerman, Hopp \& Lee, 1987).

\section{- Smoking}

The analysis of about 50 investigations into nurses' smoking behavior in 20 countries showed nurses' smaking prevalence is as high or even higher than the general populations' smoking prevalence. Only in Finland and Canada, female nurses smoke clearly less than the female population. In the late sixties and early seventies the majority of nurses smaked in the USA, the UK, and Australia. A slow decrease in the proportion of smoking nurses has taken place over the last decade in these countries. In the late 
seventies the majority of nurses still smoke in Denmark and Austria, and nowadays in Portugal and Spain. More male nurses smoke than do females. Recently, majorities of non-smoking nurses were found in almost all countries studied, except among male nurses in Portugal and Spain. Of Dutch female nurses, $41 \%$ were currently smoking in 1981, while the prevalence of smoking among females in the general population then was 36\% (Adriaanse, Van Reek \& Evers, 1986).

\section{"Alcohol consumption}

Analysing drinking patterns among future nurses at a nursing college $(\mathbb{N}=110 ; \mathrm{RR}=93 \%)$, Haack and Harford (1984) report $55 \%$ to be drinking regullarly. Overdrinking, ile. six glasses or more per sitting was reported to have occurred in $47 \%$, during the last month. The estimated number of alcoholic nurses in the USA is varying between 40,000 and 75,000 (Bissell \& Haberman, 1984; Bissell \& Jones, 1981; Levenstein, 1980). Alcoholism among nurses is an underestimated problem, although the rate is similar to the rate found among the general female population. Alcoholism among nurses went unchecked much longer than it did amongst physicians (Bissell \& Jones, 1981; Isler. 1978).

\section{* Coffeo}

Of non-smoking nurses over half ( $59 \%$ ) used no coffee at all, $27 \%$ one to three cups a day, while $14 \%$ used more than three cups. Of smoking nurses, however, only $28 \%$ used no cotfee at all, $41 \%$ used one to three cups of coffee a day, while $31 \%$ had more than three cups of coffee a day (Rausch ot al., 1987).

\section{"Breakfast}

Among non-smoking nurses $34 \%$ used breakfast 5 to 7 times a week, among exsmokers $57 \%$, while among those who currently smoked only $18 \%$ had breakfast regularly (Rausch ot al., 1987).

"About nurses" general health behavior and other specific health behaviors no data were available.

\subsubsection{Health behavior In general practitloners}

\section{" General health behavior}

Physicians' health behavior was subject to investigation already in the early sixties but in a negative sense. Physicians drug and alcohol abuse, disproportionate incidence of mental disorders and suicide were reported (AMA, 1973; Lens, 1984; Glaser, Brewster \& Sisson, 1986). Whille the focus here is health behavior, alcoholism, drug abuse, and other pathology will only be reterred to brietly.

Patient Care's survey on health habits among 1,000 randomly chosen physician readers showed that $31 \%$ was dieting. $27 \%$ smoking (over one third cigars or pipes, two thirds cigarettes) "10\% was overwoight. Regular physical examinations were taken only by half of the responding physicians. Only $13 \%$ thought their health to be a problem, hypertension $(13 \%)$ and obesity $(11 \%)$ being most frequently reported causes. Working 45 hours and over is reported by $64 \%$ (Kasanov, 1976). Physicians' health behavior was surveyed more recently in a Philadelphia Academic Health Center ( $N=636 ; \mathrm{RA}=47 \%$ ), by means of HPL's health practices index. Only $19 \%$ of the Philadelphia physicians were 
cigarette smokers, $25 \%$ rarely or never had breakfast while $39 \%$ hardly ever had snacks between meals. Whereas $5 \%$ were abstainers, $61 \%$ were infrequent allcohol consumers. Three out of four physicians slept the recommended seven or eight hours. More than one hour of exercise weekly was practised by four out of five physicians. Less than $25 \%$ of the physicians had their last asymptomatical medical visit within the last year. Health Practices indexes of four and over were found for $86 \%$ of the physicians: intercorrelations were low. Although less physicians smoked than there were smokers among the general population, physicians were concluded to not engage in substantially less prevention activity than the general public' (Glanz, Fie \& Walker, 1982a). Eating breakfast was the health practice found to be most frequently associated with other positive health practices. Item-total correlations of separate health practices, except for limited drinking, were highly significantly correlated with the total number of health practices, varying from .26 to .44 (Glanz, Fiel \& Walker, 1982b).

In a survey of health promoting behaviors among Massachusetts physicians $(\mathrm{N}=462$; $\mathrm{RR}=70 \%$ ), three out of four appeared to be engaged in at least one physical activity per week. The majority used seatbelts while $15 \%$ reported to have a rifle in the home for safety reasons. Only $14 \%$ were cigarette smokers, while more than half of the physicians had stopped smoking. Whereas abstainers hardly exist, problems with drinking were reported by $3 \%$. Breakfast is skipped by only $4 \%$; half of the physicians observe dletary restrictions. High pressure in practice was reported by $37 \%$, working over 60 hours by $33 \%$. Only $23 \%$ slept 8 hours. Not more than $14 \%$ had favourable practices on three wellknown factors commonly used in risk appraisal (smoking, seatbelt use and jogging) (Wyshak, Lamb, Lawrence \& Curran, 1980).

In a 20-year follow-up study (1961-1981) of University of Georgia physicians $(N=431$; $\mathrm{RR}=73 \%$ ) multiple divorced physicians were more likely to smoke (prevalence $47 \%$ $(\mathrm{N}=19)$, than those once divorced $(15 \%, \mathrm{~N}=79)$ and those married $(\mathrm{N}=390)$. Regularity of breakfast was related inversely (respectively $32 \%, 53 \%$ and $65 \%$ had regular breakfast (McCranie \& Kahan, 1986).

Using a four-health practices index, consisting of smoking, drinking, physical activity and weight for height, Lens found $54 \%$ of Dutch general practitioners in a nationwide sample $(N=500 ; R R=61 \%)$ to live healthily. However, they do not take care of themselves very well: preventive medical check-ups were taken by $9 \%$ of the Dutch general practitioners only. While $49 \%$ were current smokers, $19 \%$ indicate potential or current problems with alcohol consumption (Lens, 1984). In a Belgian study on general practitioners" health behavior, a suburban sample $(N=50 ; R R=66 \%)$ was interviewed. Lack of time appeared to be a stressor. Medical check-ups were taken by $40 \%$ of general practitioners in Gent, where only $20 \%$ was current smoker. Half of the general practitioners is using alcohol daily, and reports to know colleagues with drinking problems (Dutré, Eho, Elewaut et al." 1984).

In a recent review of the literature on physicians" own health, physicians said to have outstripped the general public with regard to smoking cessation by far. Sulcide rates, alcoholism and drug abuse are higher among American physicians than among the general population. Alcoholism among drinking physicians is $7 \%$ : the physicians' "invulnerability syndrome" is a serious risk factor (Clever \& Arsham, 1984). 
Lee suggested that the reduced smoking-related mortality in English doctors has been counterbalanced by an increase in stress-related mortality (1.e. due to poisoning, suicide and citrhosis of the liver) (Lee, 1979).

Recently, Rimpela and her colleagues found that Finnish doctors do not use their professional knowledge and skills in a way that reduces their own mortality risk: possible hazards are more likely to be mental than physical or chemical. Athough overall mortallity of Finnish physicians in 1971-1980 was lower than that among all economically active men, risk of sulicide was twice as high for doctors as for other professions. Lower cancer mortality rates for doctors and higher suicide rates than in all economically active males were found in Norway and Denmark also (Rimpelä, Nurminen, Pullkkinen, Rimpelä \& Valkonen, 1987). Simillar problems with physician's health have been reviewed by Murray (1978).

\section{- Smoking}

Comparison of time trends in smoking prevalences found among physicians in 34 countries in the period 1951-1986 showed that physicians have been smoking less than the general population, except for male physicians in Portugal and France, Dutch general practitioners, and female physicians in Finland, USSR, Japan, Portugal, and Spain. Physicians' smoking prevalences were decreasing continually almost everywhere. Over time, there appears to be a positive relation between the reduction of smoking among male physicians and male populations' smoking prevalences in most countries. For females this relationship is found much less. More than anywhere else, physicians in Scandinavia, the USA and the United Kingdom have had the lead on the population's smoking decline. Physicians on the European continent mostly lag behind (Adriaanse, Van Reok and Van Zutphen, 1986; 1987). The prevalence of smoking among Dutch general practitioners was $64 \%$ in $1977,51 \%$ in 1981 , and $48 \%$ in 1982 . Among malles in social class $A$, smoking prevalences at these points in time were 53,45 , and $39 \%$; among the general population males the corresponding prevalences were 56,47 , and $41 \%$ (Adriaanse, Van Reek \& Meisemakers, 1986).

\section{- Alcohol consumption}

Whereas specific mortality rates for lung cancer convincingly illustrate that physicians' smoking prevalence is lower than the general populations' smoking prevalence, specific mortality rates for cirrhosis of the liver "over three times as high among physicians in England than among the general population, illustrate the problem of excessive alcohol consumption in the medical profession (Rawnsley, 1984). Few abstainers are found among physicians; $8 \%$ in 1972 (Lipp \& Benson, 1972), 12\% in 1984 (Niven, Hurt, Morse \& Swenson, 1984) in the USA; much more abstainers were found in the Japanese medical profession: $31 \%$ were abstainers, whilst $31 \%$ occasional and $38 \%$ daily consumers of alcohol (Kono, Ikeda, Ogata, Tokudome, Nishizumi \& Kuratsune, 1983).

In 20-year follow-up study of the health of Johns Hopkins student cohorts $(\mathbf{N}=1117)$. about one third of the physicians appeared to be daily drinkers in 1964, while another third were occasional drinkers. Their average consumption was 2.5 glasses per day (Thomas, Santora \& Shafer, 1980). Physicians drink more than a comparable male group in the same social class in North America and the UK (Bissell \& Jones, 1976; Glatt, 1974, 1977; Murray, 1976; Gilber, 1980; Bissell Haberman, 1984). The 
alledgedly higher alcoholism rate among physicians in comparison with the general population is refuted by Niven. Hurt, Morse \& Swenson, who found equal alcoholism rates among physicians and general medical patients (Niven, Hurt, Morse \&wenson, 1984). In the Netherlands, relatively high alcoholism test scores for Dutch general practitioners and dentists who were used as controls, were found (Lens, 1984). In Scotland, admissions in psychiatric hospitals were 2.5 times higher amongst doctors than amongst males of social class I (Murray, 1976).

\section{- Coffee}

In the Johns Hopkins follow-up study, coffee consumption was found to have increased significantly over 20 years from an average of about 2.4 cups per day to about 3.5 . The unhealthy group of physicians drank more coffee than the healthy group (Thomas, Santora \& Shaier, 1979).

\section{* Breakfast}

In the follow-up study on 431 University of Georgia physicans, $70 \%$ reported eating breakfast regularly (McCranie \& Kahan, 1986). The information presented in paragraph 3.3 is synthesized in the next table in order to have a clearer view on the data presented and on those lacking (table 3.1).

Table 3.1: Overview of health professionals' health behavior research

\begin{tabular}{|c|c|c|c|}
\hline Health behavior & Schoolteachers & Nurses & Physlclans \\
\hline \multirow[t]{2}{*}{ regular breakfast } & - & $34 \% S_{n}$ USA, 1987 & $96 \%$ USA, 1980 \\
\hline & & $18 \%$ NS,USA, 1987 & \\
\hline immoderate & $25 \%$ Finland, 1985 & $31 \% S_{n}$ USA, 1987 & - \\
\hline coffee consumption & $14 \% N_{n}$ USA, 1987 & & \\
\hline teeth brushing & - & - & - \\
\hline dental checkup & - & - & - \\
\hline snacking in between meals. & - & - & $60 \%$ USA, 1982 \\
\hline sugar & - & - & - \\
\hline \multirow[t]{2}{*}{ alcohol abstention } & $20 \%$ Finland, 1985 & - & B\%, USA, 1972 \\
\hline & $24 \%$ Belgium, 1981 & & $5 \%$ USA, 1982 \\
\hline \multirow[t]{2}{*}{ regular drinking } & $34 \%$ Bolgium, 1981 & $55 \%, \cup S A, 1984$ & $12 \%$ USA, 1984 \\
\hline & $21 \%$ Neth. 1987 & & 31\% Japan, 1983 \\
\hline Immoderate drinking & - & $47 \%$ USA, 1984 & \\
\hline sleep & - & - & $23 \%$ USA, 1980 \\
\hline $7-8$ hours & & & $75 \%$ USA, 1982 \\
\hline Quetelet index & - & - & $10 \%$ USA, 1976 \\
\hline \multicolumn{4}{|l|}{ overweight } \\
\hline washing thands & - & - & - \\
\hline safety belt & - & - & - \\
\hline \multicolumn{4}{|l|}{ smoking currently } \\
\hline male & $17-82 \% W W$ & $32-77 \% \mathrm{WW}$ & $19-82 \% \mathrm{WW}$ \\
\hline female & $3-41 \%$ WW & $3-57 \%$ WW & $7-64 \%$ WW \\
\hline
\end{tabular}




\subsection{Discussion}

From the review of the literature it can be concluded that results of research into specific health behaviors obviously do not necessarly contribute to the understanding of the extent to which health behavior is a comprehensive entity. In reality, health education has to deal with intertwined health behaviors and none of them can be influenced independently, outside their context. Therefore, the value of the atomistic approach is limited.

The additivity approach of health behavior relatives has been the most successful: The Health Behavior Index is simple, well underpinned, contains core health items, and is rather widely accepted. The scaling approach of health behavior may be more satisfying from the psychometric and statistical point of view, contentwise it did not yield health behavior-sets which are comprehensive from the health care point of view. But this latter observation clearly relates to the preference for the morbidity/mortality criterion for inclusion ${ }_{*}$ a choice which has been made in this investigation"s operationalization of health education behavior (see Chapter 7).

Only small parts of variance in health behavior have been explained. Research has not been very successful, because approximately $80 \%$ of the variance in health behavior is open to situational factors. Pill \& Stott anticipate an increasingly complex situation, in which it will be a major challenge to conceive a more comprehensive theoretical basis for preventive health behavior (Pill \& Stott, 1985). Upon the usefulness of their "cascade"concept, a metaphore meaning to describe the complex interaction of factors culminating in a given health behavior; "cascade" because the shape and the direction of a cascade is the resultant of streams from different sources (content) and the topography (context), future research will have to shed light.

\subsection{Conclusion}

In conclusion, it can be saild that the literature review showed that contentwise, the additivity approach produced the most satisfying result, i.e. a comprehensive health behavior-variable containing the core health behaviors. Methodologically, the scaling approach produced the most satisfying result, 1.0 . a health behavior-scale with interval characteristics. The only better instrument would be the one which combined these characteristics, contentwise and mothodologically.

\subsection{Summary}

The literature on health behavior is summarized. Conceptualizations of health behavior are ranging from illiness-centered to health-centered. Health behavior's domain can be delineated on the basis of expert criteria (morbidity, mortality) andror lay opinions.

Operational ization of health behavior as a variable is based on an atomistic, an additive or a scaling approach. The dimensionality of thealth behavior is subject to a discussion with diverse points of view: uni dimensionality as well as bi- and multidimens lonality have been defended. Human Population's Laboratory's Health Practices Index contains seven core health items. 
Research into health behavior of teachers, nurses and physicians is summarized. Though smoking is relatively well-documented and some data are available about alcohol consumption, hardly any data exist about other health behaviors, except for physicians. General health behavior as such has been investigated among physicians only. Teachers smoke less than the general population. Female nurses smoke as much or more than the female population. More Dutch general practitioners smoke than males in the population at large do. In many countries general practitioners have had the lead in smoking reduction, but the medical profession has had problems with alcohol and drugs. Their general health behavior is not better than the health behavior in the general population. 


\section{References}

Adriaanse, $\mathrm{H}_{4}$, Van Reek, $\mathrm{J}_{,}$1986. Teachers" smoking worlowide. A review of 19 countries. International Quarterly Community Health Education, 3-17.

Adriaanse, H., Van Reek, J., Evers, G., 1986. Rookgewoonten van verpleegkundigen wereldwijd. Nedertands-Vlaams Tijdschrift voor Verpleegkundigen, 3, 133-145. (Nurses smoking worldwide).

Adriaanse, H., Van Reek, J. Metsemakers, J., 1986. Smoking behavior of Dutch general practitioners in the penod 1977 - 1983. Scandinavian Journal of Primary Health Care 4 , $151-156$.

Adriaanse, H., Ven Reek, J., Van Zutphen, W.M., 1986. Rookgewoonten van artsen wereldwijd. Nederlands Tijdschrift voor Geneeskunde, 49, 2224-22:29. (Physicians" smoking worldwide).

Adriaanse, H., Van Reek, J., Van Zutphen, W.M. 1987 . Arts en roken, de woorbeeldrol van de arts met betrekking tot de rookgewoonten van de algemene bevolking. Medisch Contact, 9 , 265-267. (General practitioners' smoking, exemplary role with regard to the general population).

Albanes, D., Jones, D.Y., Micozzi, M.S., Mattson, M.E., 1987. Associations between smoking and body weight in the US population: Analysis of NHANES. American Journal of Public Health, 4, 439-444.

AMA Council on Mental Health, 1973. The sick physician: impairment by psychiatric disorders, including alcoholism and drug dependence. Journal of the American Medical Association, 6. $684-687$.

Aro, S., Rasanen, L. Telama, R., 1986. Social class and changes in health-related habits in Finland in 1973-1983. Scandinavian Journal of Social Medicine, 14, 39-47.

Belloc, N.B., 1973. Relationship of health practices and mortality. Preventive Medicine, 2, 67-81.

Belloc, N.B., Breslow, L., 1972. Relationship of physical health status and health practices. Preventive Medicine, 3, 415-421.

Berkman, L.F.; Breslow, L., 1983. Health and ways of living - the Alameda County Study. Oxford University Press: New York/Oxford.

Berkman, L.F., Syme, S.L., 1979. Social networks, host resistance and mortality: a nine-year follow up study of Alameda county residents. American Jaurnal of Epidemiology, 2, 186-204.

Bissell, L. Haberman, P., 1984. Alcoholism in the professions. Oxford University Press, New York Oxtord.

Bissell, L., Jones, R.W., 1976. The alcoholic physician: a survey. American Joumal of Psychiatry, $133,1142-1146$.

Bissell, L., Jones, R.W., 1981. The alcoholic nurse. Nursing Outlook, 2, 96-101.

Breslow, $L_{n, i}$ 1972. A quantitative approach to the WHO-delinition of health: physical, mental, and social well-being. International Journal of Epidemiology, 4, 347-355.

Breslow, L.F., Enstrom, J., 1980. Persistence of health habits and their relationship to mortality. Preveventive Medicine, 9, 469-483. 
Calnan, M., 1985. Patterns in preventive behavior: a study of women in middle age. Social Science and Medicine, 3, 263-268.

Calnan, M. Rutter, D.R., 1986. Preventive health practices and their relationship with sociodemographic characteristics. Health Education Research, 4, 247-253.

Clever, L.H., Arsham, G.M. 1984. Physicians" own health - Some advice tor the advisors. Western Journal of Medicine, 6, 846-854.

Curlette, N.L., Canella , K.S., 1985. Going beyond the narrative summarization of research findings: the meta analysis approach. Research in Nursing and Health 8, 293-301.

Dooghe, G., VandenBoer, L., Van Loon, F., 1984. Verantwoordelijkheid voor eigen gezondheid: een typologie als synthese. Beligische Archieven voor de Sociale Geneeskunde, 5/6, 253269. (Responsibility for personal health: a typology as a synthesis).

Dutre, J., Eho, D., Elewaut, C., Everaert, K., Eylenbosch, H., Follebout, J., Frankel "U., Geurs, F., Raweel, E.. 1984. Gezondheidsgedrag van de arts. Paper Laboratorium voor de Gezondheidsleer en Sociale Geneeskunde, Rijksuniversiteilt Gent. (Physicians" health bethavior).

Freeman, H.E., Lambert, $C_{n}, 1965$. Preventive dental care of urban mothers. Journal of Health and Human Behavior, 6, 141-147.

Furer, J.W. Tax, B., Heyendaal, P.H.J.M., Konig-Zahn, C., Persoon, J.M.G., 1987. Bespreking van de resultaten van enkele vervolganalyses. In: Furer, J.W. \& Persoon, J.M.G. (Eds.), 1987. Ziektegedrag en sociaal-culturele context. Eindrapport van het Regioproject Nijmegen. Deel II. Instituut voor Sociale Geneeskunde, Katholieke Universitteit Nijmegen, Nijmegen, p. 81-130 (lliness behavior and sociocultural context).

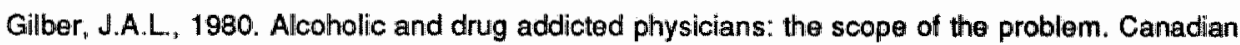
Family Physician, 26, 851-853.

Glanz, K., Fiel, S.B., Walker, L.R., 1982a. Physicians' health beliefs, health practices and health status: a survey. Paper APHA, Annual Meoting, Montreal, Canada.

Glanz, K., Fiel, S.B. Walker, L.R. Levy, M.R., 1982b. Preventive health behavior of physicians. Journal of Medical Education, 5, 637-639.

Glaser, F.B., Brewster, J.M., Sisson, B.V., 1986. Alcohol and drug problems in Ontario physicians: characteristics of the physician sample. Canadian Family Physician, 32, 993-999.

Glatt, M.M., 1974. Alcoholism among doctors. Lancet $342,11$.

Glatt, M.M., 1977. Characteristics and prognosis of alcoholic doctors. British Medical Journal, 507.

Gottlieb, N.H., Green, L.W., 1984. Life events, social network, life-style and health.. An analysis of the 1979 National survey of personal health practices and consequences. Health Education Quarterly, 1, 91-105.

Graig. M., 1981. The health professional and alcoholism. New Zealand Nursing Journal, 74, 8.

Green, L.W., 1968. Status inconsistency, reference group theory, and preventive health behavior. Dissertation University of California at Berkeley.

Green, L.W., 1970. Status Identity and Preventive Health Behavior. Pacific Health Education Reports, no. 1, Berkeley University of California.

Green, L.W., 1984. Modifying and developing health behavior. American Review of Public Health, 5, 215-236. 


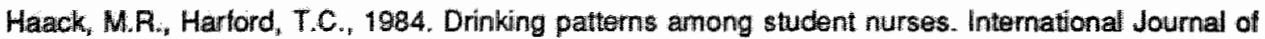
Addictions, $5,577-583$.

Hallens, A., 1985. Locus of Control: de beheersingsontentatie in relatie tot ziekte- en gezondheidsgedrag. Dissentation University of Limburg, Maastricht. (Locus of Control in relation to illness and health behavior) (with English summary).

Harris, D.M. Guten, S., 1979. Health protective behavior: an exploratory study. Journal of Health and Social Behavior, 1, 17-29.

Hays, R., Stacy, A.W. Dimatteo, M.R., 1984. Covariation among health-related behaviors. Addictive Behaviors, $3,315-318$.

Heyerick, J.P., Maes, L., De Maeseneer, J. et al, 1981. Gezondheid, je kan er zelf iets aan doen. Diensten van de Eerste Minister Wetenschapsbeleid, Brussels. (Health, your responsibility, a feasability study).

Istvan, U., Matarazzo, J.D., 1984. Tobacco, alcohol and caffein use: a review of their interrelationship. Psychological Bulletin, 2, 301-326.

Isler, C., 1978. The alcoholic nurse; what we try to deny. Nursing Research, 48-55.

Kannas, L., 198\%. The dimensions of health behavior among young men in Finland. International Journal of Health Education, 3, 146-155.

Kasanov, D., 1976. How doctors take care of themselves. Special Survey Patient Care, 8, 49-59.

Kasl, S.V., Cobb, S., 1966. Health behawior "illness behavior and sick-role behavior. I. Health and Illness Behavior. Archives of Environmental Health, 12, 246-266.

Kinnunen, U., Mäkinen, R., Vihko, V., 1985. The level of teacher stress over a school year. Report. Institute of Educational research, no. 363. University of Jyvăskylä, Jyväskylä.

Knibbe, R., 1984. Van gangbaar tot problematisch drankgebruilk. Dissertatie. Rijksuniversiteit Limburg. (From convivial to problematic alcohal consumption. Dissertation, University of Limburg).

Kono, S., Ikeda, M., Ogata, M., Tokudome, S., Nishizumi, M., Kuratsune, M., 1983. The relationship between alcohol and mortality among Japanese physicians. International Journal of Epidemiology, 4, 437-441.

Kristiansen, C.M., 1985. Value correlates of preventive health behavior. Journal of Applied Social Psychology, 3, 748-758.

Kristiansen, C.M., Harding, C.M., 1984. The measurement of preventive health behavior. Paper University of Exeter.

Langlie, J.K., 1977. Social networks, health beliefs and preventive health behavior. Journal of Health and Human Behavior, 18, 244-260.

Langlie, J.K., 1979. Interrelationship among preventive health behaviors: a test of competing hypotheses. Public Health Reports, 3, 216-225.

Lee, P.N., 1979. Has the mortality of male doctors improved with the reductions in their cigarette smoking? British Medical Journal, 1538-1540.

Lens, P., 1984. Zleke dokters. Bunge: Utrecht. (The sick physician). 
Levenson, P.M., Morrow, J.R., Pfefferbaum, B.J.. 1984. Attitudes towards health and illness: a comparison of adolescent, physician, teacher and school nurse views Joumal of Adolescent Health Care, 5, 254-260.

Levenstein, A, 1980. Alcohol and tension. Supervisor Nurse, 3, 46-47.

Lipp, M.R., Benson, S., 1972. Physicians use of marijuana, alcohol and tobacco. American Joumal of Psychiatry, 5, 124-128.

McCranie, E.W., Kahan, J., 1986. Personality and multiple divorce: a prospective study. Journal of Nervous and Mental Disorders, 3, 161-164.

Mechanic, D., 1979. The stability of health and illiness behavior: results from a 16-year follow-up. American Journal of Public Health, 69, 1142-1145.

Mechanic, D., Cleary, P.D., 1980. Factors associated with the maintenance of positive health behavior. Preveventive Medicine, 6, 805-814.

Mesters, $F_{n}, 1987$. Alcohol- and drugsvoorlichting op de MAVO resultaten van cen landelijk onderzoek naar de ervaringen van docenten met woorlichting over alcohol en drugs. Federatie van Instellingen voor Alcohol en Drugs FZA: Bilthoven. (Alcohol- and drugs education in highschool).

Murray, R.M., 1976. Alcoholism amongst male doctors in Scotland. Lancot, 729-731.

Murray, R.M., 1978. The health of doctors: a review. Journal of the Royal College of Physiclans, Londion, 5, 403-415.

Nathanson, C.A., 1977. Sex rolles as variables in preventive health behavior. Journal of Community Health, 2, 142-155.

Niven, R.G., Hurt, R.D., Morse, R.M., Swenson, W.M. 1984. Alcoholism in Physicians Mayo Clinical Procoedings, 59, 12-16.

PIII, R., Stott, N.C.H., 1985. Preventive procedures and practices among working class women: new data and fresh insights. Social Scienco and Medicine, 9, 975-983.

Rajala, M., Honkala, E., Aimpela, M.K., Lammi, S., 1980. Toothbrushing in relation other health habits in Finland. Community Dental and Oral Epidemiology, 8, 391-395.

Rausch, J.C., Zimmerman, G., Hopp, J., Lee, J., 1987. Smoking behavior of student nurses enrolled in diploma, associate degree and undergraduate nursing programmes. Joumal of Advanced Nursing, 12, 111-119.

Rawnsly. K. 1984. Alcoholic doctors. Alcohol and Alcoholism, 19, 3, 257-259.

Rimpelä, A.H. Nurminen, M.M., Pukinen, P.O. Rimpelä, M.K., Valkonen, T., 1987. Montality of doctors: do doctors benefit from their medical knowledge? Lancet, 84-87.

Rosenstock, I.M., 1966. Why people use health services. Millbank Memorial Fund Quarterly, 3/4l, 94-126.

Fosenstock, I.M., 1974. The Health Bellef Model and preventive health behavior. In: Becker, M.H. The Health Belief Model and personal health behavior. Slack, Thorolare N.J., $27-59$.

Steele, JL., McBroom, W.H. 1972. Conceptual and empirical dimensions of health behavior. Journal of Health and Social Behavior, $13,382-392$. 
Tapp, J.T, Goldenthal, P., 1982. A factor-analytic study of health habits. Preventive Medicine, 11, 724-728. Thomas, C.B., Santora, P.B., Shafer, J.W., 1980. Health of physicians in midlife in relation to the use of alcohal: a prospective study of a cohort of former medical students. The Johns Hopkins Medical Joumall, 1, 1-10.

Williarns, G. Harnly, M., 1982. Health status and health habits assessment. Medical Information, 3, 197-207.

Williams, A.F., Wechsler, $H_{3}, 1972$. Interrelationships of preventive actions in health and other areas. Health Services Reports, 10, 969-976.

Wingard, D.L., Berkman, L.F., Brand, A.J., 1979. A multi-variate analysis of health practices: a nine-year mortality follow-up of the Alameda County Study. Paper Human Populations Laboratory Berkeley.

Wyshak, G. Lamb, G., Lawrence, R.S., Curran, W.J., 1980. A profile of health-promoting behaviors of physicians and lawyers. New England Journal of Medicine, 2, 104-107.

Zahourek, A.P., 1981. Even "people helpers" need help. Stress and addictive behaviour in nurses. Imprint 9, 31-33; 69-74. 


\section{Chapter 4. Exemplary role}

Introduction

4.1 Conceptualization

4.2 Exemplary role of key health professionals

4.2.1 Schoolteachers' exemplary role with regard to health

4.2.2 Community nurses' exemplary role with regard to health

4.2.3 General practitioners' exemplary role with regard to health

4.3 Discussion

4.4 Conclusions

4.5 Summary 
"Philosophically, a physician who smokes (...) is in the position of a policeman who breaks the law; a clergyman who sins; an accountant who overdraws his checking account; a banker who goes bankrupt or a Ford dealer who drives Chevrolets" (Bates, 1983).

\section{Introduction}

In this investigation the focus is on key health professionals' health educational tasks, their actual health behavior, whenever possible compared to the general population and on their perception of an eventual exemplary role of themselves towards their respective target groups. The public expects health workers and educationalists to live up to the health norms they set for patients and pupils. Leading protessionals regularly express as their view that it is part of their duty to behave in accordance with the health norms. The contrary position, i.e. asserting that professionals have the same liberties for personal choices of health related habits as an individual in society is defended also, be it less frequently.

In this chapter the perception of an eventual exemplary role, the expectations of the professionals and of the general public, as well as the scarcely documented effects of exemplary behavior by key health professionals are reviewed. It should be mentioned that many authors expressed their opinion on key health professionals' exemplary role, fow reported about others" opinions, trying to theoretically underpin the notion, and hardly any author's report about effects of exemplary behavior.

\subsection{Conceptualization}

Very often the notion of exemplary role is assumed to have enough sell-explanatory power and more precise definition of the concept is considered unnecessary, or in any case, not given. Conceptual clarification is necessary, however. In this chapter literature relevant for the theoretical and the practical understanding of the exemplary role of key health professionals with regard to health is reviewed. General theories which are helpful to understand and clarify the exemplary role are role theory and social learning theory. especially modeling.

Furthermore, the literature on the perception of the exemplary role among key health professionals is reviewed. To what extent is the exemplary role part of key health professionals' task perception; to what extent do they actually perform this task? Why do teachers, nurses and physicians argue that exemplary role fulfilment is either a moral imperative - let alone its assumed efficacy - or an empirical imperative - based on public's expectations and evidence of its effects?

It should be pointed out at the outset that only plain empirical and no theory-based investigations in the exemplary role behavior with regard to health have been carried out among health professionals.

It should also be mentioned that the exemplary role is only one variable in a complex of factors determining health behavior, as is shown in Horn"s model (Horn, 1976). 
Figure 1. Elaboration of factors governing cessation (or other modification) of the behavior (Horn, 1976).

Cessation (or other risk-reducing modlification)

Motivation for change: values
a. Health
b. Exemplary
c. Esthetics
d. Control

Perception of
the threat

a. Importance

b. Personal influence

c. Value of change

d. Capability of making change

Psychological
utility

a. Stimulation

b. Handling

c. Accentuation of pleasure pleasurable relaxation

d. Reduction of negative effect

๑. Psychological addiction "craving"

f. Habit without affect
Environmental facilltation
a. Physician influence
b. General climate of opinion
c. Influence of advertising
d. Influence of key groups
•. Interpersonal influences

In Horn's model determinants of the motivation for change, of the perception of the threat, of the psychological utility and of the environmental facilitation of personal health behavior are summarized. Horn's model, which is meant as a framework for further research into initialization, establishment, maintenance and modification of health behavior, explicitly mentions the exemplary role as one of four major determinants of motivation for change (Horn, 1976). In fact, the influence of key health professionals is especially important because it again is mentioned twice as determinants of the "environmental facilitation": "physician influence" and "influence of key groups".

\section{Theoretical background}

The notion of exemplary role emerged from lay language and had its place in the practical discourse of professionals involved in education and health care long before any systematic attention was paid to the phenomena in the teaching and/or health care settings. Both role theory and social learning theory can be helpful to clarify the notion of exemplary role as it was coined in professional discourse. Although within role theory the concept of role itself has not been defined operationally in a universally accepted way (Biddle, 1979; Visser et al, 1983), the concepts derived from it have been defined more precisely. From these notions related to the central concept of role, the following are especially relevant to clarify exemplary role's conceptualization:

- role-performance, i.e. the behavior any role occupant performs relevant to a specific position;

- role-sender, or counter-role occupant, is a person occupying an interdependent position and holding role expectations for the occupant;

"role-expectations, i.e. the specific norms that identify the attitudes, behaviors, and cognitions that are required for a role occupant (Hardy and Conway, 1978). Role performance also covers behavior a model intentionally does not perform (Visser et al, 1983). 
Within social learning theory, the notion of modeling is highly relevant to the study of the exemplary role. Somewhat loosely, modeling is described as follows by Bandura: "Most human behavior is learned observationally through modeling. Because people can learn from example what to do, at least in approximate form, before performing any behaviour they are spared needless errors". Modeling applies to overt and covert, to motor as well as cognitive skills; it is assumed to be a vehicle for continuity as well as for behavioral innovation (Bandura, 1977).

The example is considered to be one of the most important modeling clues: "the power of the example in eliciting and channeling behavior has been well documented in laboratory and field studies" as observed Bandura. Noll all models are equally effective: high status, competence and power are more effective in prompting others to behave similarly than are models of lower standing (Bandura, 1977).

In reviews of theories of social learning and imitative behavior, Bandura's social learning theory has been pointed to as by far the best available theoretical view (Flanders, 1968; Shaw \& Costanzo, 1981). Bandura posits that a model's behavior is a source of information for the observer. In his view four processes are triggered off when observer O observes $M$ : the attention process, the retention process, the motor reproduction process and the motivation process, leading from initially modeled events to the matching performance.

Lichtenstein \& Danaher stress that the role of the physician as a model or exemplar is at the heart of the model because it is hierarchical from the center to the periphery. In addition to this role as a model, Lichtenstein \& Danaher expect the physician to provide information about the degree of personal risk involved with certain behaviors.

Admonishment is the empathic role the physician fulfils by encouraging the patient to make choices and maintain the healthy choices. Referral and direct management indicate the monitoring of health behavior through either the physician or other health professionals (Lichtenstein \& Danaher, 1978).

Modeling only can occasion learning if the observer's attention has been aroused by the model. The attentional process is determined by modeling stimuli and observer characteristics. In the retention process, through symbolic mediation, components of the model's actions are stored in the observer's memory. The motor or verbal reproduction process is the stage in which the symbolic representation is converted into overt action; responses are selected by the observer and the model's behavlor is successively approximated. The last phase of modeling is the reinforcement and the motivational process, through which the matching performance of the modeled behavior is enacted. The modeling process is concluded by this overt matching of observed behavior.

As primary effects of successful exposure to models, Bandura found amongst others effects on the individuall level, i.e. the observer acquires new response patterns through observing a model perform highly novel responses; onsocietal level, modeling as a source of innovation in a society based on the idea that models can serve as primary exemplars for new ideas values and behavioral styles. Secondly, abstract rule transmission effects, i.e. the phenomenon that observers extract common attributes exemplified in diverse modeled responses and formulate rules for generating behavior with similar structural characteristics: "These and other illustrate the applicability of social learning theory on roles played by parents, teachers, etc. with regard to longterm 
development of (...) moral attitudes and social preferences" (Shaw \& Costanzo, 1981). An important distinction in the literature on modeling separates mastery models and coping models, the former being perfectly demonstrating flawless performance, without anxiety; the latter being initially fearful and only subsequently acquiring competence (Meichenbaum, 1971).

Role theory's notion of rolemaking, (i.e. to structure interaction in such a way as to modify it (Hardy \& Conway, 1978) and social learning theory's notion of modeling seem to be akin to each other and both indicate the option for the professional to act as a change-agent within the professional group or towards their target-groups.

Exemplary role is not only a bundle of expectancies maintained by key health professionals with regard to their own health behavior and its potential effects on their target groups. Exemplary role is also characterized by consistency or consonance. In his theory of cognitive dissonance, Festinger posits that there is a drive towards logical consistency or consonance in our attitudes towards objects which are related to each other: when two cognitive elements $A$ and $B$ are related to one another, they are dissonant if $\mathbf{A}$ implies not $B$ and they are consonant if $\mathbf{A}$ implies $\mathbf{B}^{*}$ (Festinger, 1957). Fulfilment of the exemplary role implies consonant behavior. Dependant on substance abuse may induce denial of the exemplary role, thus leading to avoidance of cognitive dissonance, which otherwise would arise.

Using the abovementioned theoretical distinctions the exemplary role on the one hand is a set of expectations with regard to health behavior existing among the professional groups themselves, and among the public (the role senders). On the other hand the exemplary role consists of a set of messages, modeling behaviors performed by the professionals, as a part of their role, intentionally or unconsciously.

\subsection{The exemplary role of key health professionals}

An exemplar is defined in Webster's Dictionary as 'one who serves as a pattern or a model: an exemplar is a person to be imitated". Key health professionals - the terminology was coined by Yarrow - are those professionals who have been identified to fulfil crucial educational roles with regard to the public's health (Yarrow, 1977). Teachers, nurses, general practitioners but also midwives, pharmacists, dentists, journalists, anchormen, politicians in health affairs act as key health professionals, consciously or not. (Baric, 1974; Lagersson, 1977; Yarrow, 1977; Egsmose, 1977; Gray \& Daubo, 1980; Gasstrin, 1981). Through their personal health practices key health professionals transter health norms and ultimately are one of the influences determining the public"s health behavior: "Much of the value of educating students and patients in health matters lies in the example of the teacher, nurse or physican sets and not so much in the information he/she disseminates. The role of health educators as models is often overlooked, but it may be the most powerful change agent" (Glover, 1978). Exemplary role is looked at from the perspective of the professional, indicating the bundle of professionals' perceptions of their own health behaviar and its impacts on their target group, and the public at large.

In the next sections the literature pertaining to the exemplary role of teachers. nurses and physicians is summarized. 


\subsubsection{Teachers" exemplary role with regard to health}

Teachers especially are assumed to practise what they preach, because the core of their work is pedagogical in nature. For their role as a health exemplar this can cause problems in contacts with their students, because contacts are continuous and two-way communication as a precondition for learning is practised. Ways of dealing with teachers' personal practices with regard to alcohol, soft drugs, death, sexuality and mental health were indicated by Finn. Truthful responses to students" questions on teachers" personal health practices might reveal the teacher as an inappropriate role-model. The social desirability of exemplifying faultiess personal health behavior brings teachers into a position where they have to chose whether they want to discuss their own health habits openly, conceal parts of their health behavior tactically or act as 'negative models' in case their health behavior was dissonant (Finn, 1981).

Teacher-student influencing can be considered a top-down, a two-way or a bottom-up process. Analyzing teaching-learning mechanisms in health education, Pabinowitz and Zimmerli point to the importance of the two-way character of behavioral influences between teachers and students, traditionally being thought of as a top-down process. They hypothesize that, beyond the superordinate-subordinate model, another teachinglearning mechanism may be operative, through which students act as mediators of value change (Rabinowitz, 1975; Rabinowitz \& Zimmerli, 1976).

Teachers' behavior can have a modeling influence, students internalizing the norms and mimicking the behaviors of their role models. It can also elicit a preference for the reverse norm and turn students off; the teachers function as negative models then. In an analysis of influences of significant others, carried out among students and their reported models - it concerned smoking - the model's non-smoking behavior appeared to have a net negative effect on the students' attitude to smoking. Consonant models might have negative effects (Mettlin, 1976).

With regard to specific health behaviors, there is information on the exemplar role with regard to smoking only. Most teachers agreed with statements expressing it is their responsibility to set a good example for the student by not smoking. More non-smoking teachers agreed with contentwise comparable statements on the exemplar role than did their smoking colleagues in investigations in the USA (Chen \& Rakip; 1974; Higgins, Dunn \& Warmack, 1983; Nowman, 1971), in Norway (Seip, 1977), in Roumania (Golli, 1979), and in England (Nutboam, 1987).

In the Netherlands teachers took stand against smoking early this century on the basis of results of surveys into childrens' smoking (Van Proosdij, 1957). Similarly, in many countries teacher unions adopted resolutions on the smoking issue (e.g. AAPHERD, 1971).

In a recent follow up of the 1973 study among Northhampton (USA) teachers' perception of smoking education, no significant change in exemplary role recognition over nearly ten years was found. As a strategy favoured by teachers to initiate student smoking behavior changes, setting an example by not smoking kept the second ranking it got 10 years earlier. Smoking teachers are likely to be active resisters of any smoking education: in order to protect themselves as being bad role-models they tend to discredit the value of 
smoking education. Smoking teachers are assumed to feel guilty and helpless to change themselves and help students change (Chen \& Winder, 1985):

From a cross-national study on schoolchildrens' health behavior carried out in Austria, England, Finland and Norway it appeared that smoking teachers tend to not include education about the hazards of smoking. Approximately one fifth of the children reports to have a smoking teachers, one third admits not to know whether the teachers smokes or not (Kannas, Aaroe \& Gillies et al., 1985).

Within the range of health education topics, Dutch teachers were found to spend most time on nutrition and dental health. The motivation to behave exemplary was found to be one of the determinants, in addition to the curriculum of course, of successful dental health education. Substantial teacher training in dental health appeared to be needed, to achieve this motivation to behave as a model (Eykman \& Visser, 1987).

\section{Effects}

Evidence about effects of teachers' smoking behavior is hardly available. In the UK, teachers' smoking was found to be related to boys' smoking. (Bewloy, 1976; Murray, Kiriluk \& Swan, 1984). In France, in those schools where teachers were smoking in front of the class, there was a $5 \%$ higher smoking prevalence than in schools where this was not permitted. Both parents' and teachers' example are found to be directly related to smoking onset among pupils. (Cooreman, Burghard \& Pédrizet, 1978).

In Belgian research where almost half of the teachers were found to be smokers, the importance of teachers' health attitudes and health behavior was stressed (Maes, 1985). Comparable statements can be found in the Hoogveld Institute's School Health Education project baseline documents (Smits-Van Sonsbeek \& Hegger, 1976).

in an American program evaluation on dental hyglene using teachers as a model for correct toeth brushing and flossing by children, the program appeared to be ineffective in terms of improvement of oral health after 32 weeks. The treatment of a three hours workshop seemed to be insufficient to keep up teachers' motivation to set a model for dental health to their students (Smith, Evans, Suomi \& Friedman, 1975). The same inadequacy of teachers to pertorm as a model for brushing and flossing was reported by Boyer: also many teachers declined the responsibility for dental health education (Boyer, 1976).

\subsubsection{Nurses' exemplary role with regard to health}

Nurses' conception of exemplarity can have a broad range; as is argued by Smith who assumes prevention by example to be a personal and a professional responsibility: "Nurses are endowed by the public with charismatic qualities, so whatever they see us doing they tend to assume that is right, good and proper*. Consonant behavior should be practised by nurses with regard to smoking, nutrition, car safety, hygiene and tidyness. "Nurses have to provide an ideal model of behavior for the community at large promoting much happiness, social good and positive health" (Smith, 1984).

Nurses' reluctance to investigate patients' drinking habits is criticized: nurses should be positive models as they are in a primary position to influence society (Craig. 1981). 
Clarke, Brooks \& Philips tested the hypothesis that nurses" smolking would be negatively related to the health education behavior of the nurse. Their line of reasoning was based on Festinger's theory of cognitive dissonance (Festinger, 1957). The assumption that the "nurses inevitably serve as exemplars and models to patients and to more junior nurses" was not tested, but just made explicite (Clarke. Brooks \& Phillips, 1984).

With regard to specific health behaviors, there is empirical evidence on the exemplar role with regard to smoking only. The necessity of providing a non-smoking model has been stressed regularly (Scholes, 1979; 1982). The profession has a duty to attempt to regulate the behavior of nurses only in so far as it affects patients or clients. (Working group of nurses in Scotland, 1981). Opportunity for and necessity of an exemplary role is Illustrated by the following citations:

Nurses (..) are in a vital position to promote health by helping people to understand the risks of smoking and the dangers of second hand smoke, and by becoming exemplars of good health practice themselves. Nurses can play a major role as educators and exemplars in influencing the public's smoking behavior (Hoffman-Monnies, 1983; Lazenby, 1984).

If her cigarette pack falls out of her pocket as she counsels a smoker or if she smokes where patients can see her, she is not setting a good example and her credibility with the patient will decrease. The nurse is an ideal person to counsel the hospitalized smoker, since she is close to the patient and is seen by the pationt as a crodible health worker' (Fuhs, 1976).

"We have a duty as members of a profession, to try to improve our image in the eyes of the public. We cannot expect our advice to be listened to or our instructions followed if we are obviously not obeying the rules ourselves" (Begley, 1982).

The conclusion that there is enough opportunity and also a painful necessity to perform an exemplary role is shared by Rosen and Ashley, who carried out an extensive literature review of the linternational literature on smoking and the role of health professionals. They identified five major roles for the health professional: exemplar, educator, lidentifier of risks, modifier of risk behavior, lobbyist, and researcher. The first raniking role of exemplar had not been sufficiently recognized by nurses especially not to the same extent as by other health professionals: there exists a credibility gap. Their assessment of the situation in 1978 is that, although it is clear that nurses have not realized their full potential in counteracting smoking, insufficient data are available to permit adequate assessment of role recognition and performance (Rosen \& Ashley, 1978).

At this moment more data are available from nurses in a number of countries. High agreament with statements on the exemplar role, which were contentwise comparable was measured among non-and former-smoking nurses in the USA (Eyres, 1973; Morra and Tish-Knobf, 1983; Noll, 1969; Swenson and Dalton, 1983), the United Kingdom (Spencer, 1984), and Australia (Koski, Cullingtord \& Armstrong, 1978). Recognition among their smoking colleagues was clearly lower. Nurses in Denmark agreed much less with statements on their exemplary role (Christensen, Egsmose \& Otto, 1983). In many investigations into nurses" smoking the concern about nurses not fulfilling their role 
as health exemplars is expressed (Hillier, 1973; Jacka, Disler, Sayed ot al., 1984; Philips, 1970; Raveel, 1985; Salleras-Sanmarti, 1985). Expectations of successfulness of nurses' smoking reduction are modest: only $30 \%$ of hospital inurses and $46 \%$ of community nurses expect patients to be influenced (Willinson \& Tylden-Patterson, 1984). On the other hand, smoking student nurses were found to underestimate patientoriented antismoking prevention work: heavy smokers among them think a nurse seen smoking by a patient does not influence the smoking habits of the latter (Board of Health, 1984). No data were found indicating effects of nurses' exemplary behavior.

\subsubsection{Physiclans exemplary role with regard to health}

With regard to physicians' exemplary role there is some empirical evidence and innumerable exhortations directed at the profession as a whole; only the former will be reviewed here. Do physicians practise what they preach? (Wells, Lewis, Leake \& Ware, 1984). Are physicians congruent or contradictory role models? In their research of personal health habits and practices in counseling about smoking, weight, exercise and alcohol consumption, Wells et al. found that physicians with better personal health habits counsel a broader range of patients, physicians with poor habits in more than one area are especially unlikely to counsel. This suggests a negative consonance having a double negative implication: while physicians with favourable health habits living up to the health norms they set to their patients, provide a good example to them and give information and provide counseling, those physicians who have poor health practices provide a bad example and withhold information and advice from their patients.

'Do as I say and not as I do' (Shangold). The medical profession has created a large credibility gap with the general population. Shangold's judgement is merciless: she accuses the medical profession of a double standard mentality. Doctors set poor examples knowing that teaching by example is the most fundamental educational technique. Socialization in the medical profession leads future doctors into unhealthy lifestyles (Shangold, 1979). Reacting to these findings, Elmore c.s. reporting on curricular integration of personal life style management in their medical school, posit that "it seems intuitively obvious that a health professional becomes a more effective teacher if (s)he possesses and practices the skills that they will be teaching their patients" (Elmore, Kaplan, Merians \& Farquhar, 1985). Physicians' organizations not only required exemplary behavior, but also advocated prevention issues, like seat-belt use, smolking reduction, anti-pollution action, fluoridation, use of dietary tibre, etc. Simultaneously, the need to exemplify what is taught is stressed. (Doll, 1983). As major areas within the scope of prevention Doll indicated individual life-style variables (smoking, diet, alcohol" physical activity) but also collectively determined variables as malnutrition, waste of material resources and the threat of nuclear war: these must concern doctors also (Doll 1983).

It has been argued that physicians should play an exemplary role with regard to well being in general (Stoll, 1983; Cavatailo, 1984), with reglard to exercise, jogging (Brachifield, 1978; Cavataio, 1984), alcohol consumption (Fox, 1978; Poynter, 1983) and the use of soft drugs (Lipp \& Benson, 1972). The vital role of physicians and other health professionals has been specifically stressed with regard to smoking reduction efforts: (Bates, 1983; Kunze \& Wood 1984). 
Ever since the start of Doll Hill's research into British physicians' smoking in 1951, the importance of the exemplary role of doctors with regard to smoking has been stressed frequently (Doll \& Hill, 1952; and e.g. Wieberdink \& Van Blaaderen-Stok, 1957; Ball, 1970; Fletcher \& Horn, 1970; Yarom \& Lehrer, 1971; Halhuber, 1978; Granieri, Burton \& Webster, 1978; Kellner, 1981; Baumgartner, 1982; Dekker, 1982; Wilson, 1982; Blum, 1983; 1986; Mulhearn, 1984; Steinfeld, 1984; Dunning, 1985.)

'Acting as a model of a healthy life-style by not smoking', was mentioned as the first role a physician could play in assisting a patient to stop smoking. Other roles, providing information, advice, referral, prescription and follow-up in that order subsume the prior roles. The exemplary role is subsumed by all other roles (see Figure 1; Lichtenstein and Danaher, 1978).

Figure 1: Helping roles for physician interaction with smoking patients (Lichtenstein \& Danaher, 1978).

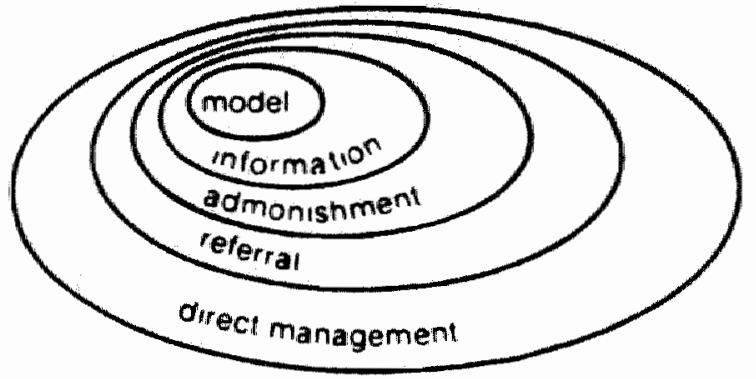

On the exemplary roie with regard to smoking specifically, in a number of investigations contentwise comparable questions were posed to physicians in America and in Europe. Exemplar role recognition was high in the USA, although expectations with regard to its effectiveness were considerably lower (CDC, 1976; Coe \& Brehm, 1971). In the UK exemplar role recognition was high among general practitioners (Jamrozik \& Fowler, 1982), moderate in all Spanish physicians (Najera, 1985), and in Israeli physicians, though high among non-smoking colleagues. (Yarom \& Lehrer, 1971). The exemplary role was recognized by small proportions of physicians in Denmark (Egsmose, Stokholm \& Egsmose, 1971; Christensen, Egsmose \& Otto, 1978) and in France (Drouin, Oudot. Grillet \& Retrolle, 1984).

In this review, effectivity of advice is not dealt with. Effects of physician's advise regarding smoking cessation have been documented elsewhere (Pedersen, 1982).

Effocts

There is not much empirical evidence about physicians" exemplary role from the general public. Most people indicated their physician should not smoke (CDC, 1976). Physicians are ranked as the most important health information source by respondents, independent of socioeconomic position (David \& Boldt, 1980). The public expects physicians to be interested in their smoking, drinking, weight, or fitness problems; less than half of the... physicians seemed interested (Wallace and Haines, 1984). There is hardly any evidence about the effects of modeling influence of physicians' exemplary role. In a highly artificial 
situation, in which patients $(\mathrm{N}=97)$ in a university clinic were exposed to either a smaking or a non-smoking physician, their exemplary role appeared to have no significant effect on the success rate, or drop-out rate. In both groups approximately $25 \%$ stopped smoking entirely during the treatment period (Poussaint, Bergman \& Lichtenstein, 1966). In an investigation into physicians ${ }^{\mathrm{F}}$ modeling influences on patient smoking, patients with internal locus of control smoked more when advised to quit, while external patients smoked mare when the model smoked and less with a non-smoking physician model. Locus of control and social desirability were found to be useful predictors for the interactive behavior of model and observer (Hanks, 1984).

Anecdatal evidence indicated that patients were knowledgeable of their doctor's smoking practice, even though the doctor never smoked in front of these patients (Strecher, 1988).

In the Netherlands, the exemplary role of general practitioners was stressed quite infrequently (see, however, Van de Weg, 1976); recognition of the exemplary role among Dutch general practitioners with regard to smoking was found to be exceptionally low (Dekker, 1981).

\subsection{Discussion}

Professionals are carrying out their activities conforming to certain ethical standards. Recognition of the exemplary role is often seen as meeting one of these ethical standards. On the other hand dissonant behavior, i.e. non-compliance with health norms key health professionals apply to their patients and their pupils, has been defended as a moral right (Hochbaum, 1980) and as an instrument with even higher efficacy than consonant behavior (Gästrin, 1981; Hochbaum, 1981). Most frequently, however, fulfilment of the exemplary role in a positive sense is pleaded for (WHO, 1984).

The review has revealed that in the professional literature in the teaching, nursing and medical settings, positive opinions with regard to the desirability of an exemplary role of key health professionals prevail, over some authors expressing reservations or even declining such a role. Responsibility for an exemplary role is mainly based on the matchdependent type of modeling, applicable both in the health care and in the school situation. Many articles reflect purely personal opinions of the authors and contain moral exhortations directed to the profession. Investigations into professionals' attitudes towards and conceptions of the exemplary role are much less frequent. Mostly, these studies reveal the existence of majorities supporting exemplary role fulfilment. Research into the relationship of the perception of the exemplary role and the health education activities, into its effects on pupils and patients, under what conditions, is nearly nonexistent.

Though role theory and especially social learning theory seem to be theories fitting quite well the needs of those researching perception and fulfilment of the exemplary role by key health professionals with regard to the health of their parents and pupils, this theoretical perspective is lacking in most of the research reviewed.

Considering key health professionals' exemplary role with regard to health, it was found that when exemplary role recognition was measured, this concerned one specific health 
behavior, most commonly smoking. Being the most clearly identifiable risk factor, smoking certainly should be a major component of any exemplary role instrument. It seems to be desirable to conceive a comprehensive instrument to measure exemplary role recognition based on a comprehensive health behavior conception.

\subsection{Conclusions}

1. Exemplary role fulfilment is basic to many other health care activities.

2. The exemplary role's potential as an instrument for change is acknowledged by health educators and by noticeable proportions with in the key health professions, whenever it concerns non-smoking.

3. Theories of cognitive dissonance and of social learning offer adequate interpretational frameworks for further research into the effectiveness of the exemplary role. However, a large number of other factors other than health educational in character codetermine its effectiveness.

\subsection{Summary}

The notion of exemplary behavior is primarily a common sense notion. Related notions from role theory and social learning theory were helpful to clarify exemplary role. Teachers, nurses and physicians are key health professionals: their health practices are relevant for the changes in the public's health behavior. Teachers' exemplary role is comprehensive due to long and close contacts with pupils. Modelling influences between teachers and pupils are discussed. Recognition of the exemplary role among smoking teachers is lower than non-smoking teachers. Evidence about effects of exemplary behavior is very scarce. Nurses' exemplary role is stressed within the nursing profession: opportunities for exemplary role performance are large but insufficiently used. Exemplary role recognition with regard to smoking is varying: concern about lack of appropriate role performance is expressed. Physicians' exemplary role is stressed within the profession and explicitly by the public. Incongruencies as among nurses are noted and the medical profession are often found to be hazardous to doctors" own health. Exemplary behavior with regard to a range of health practices is pleaded for by the medical profession itself. Recognition is high among American and English physicians, and lower among colleagues on the European continent. Pesearch into physicians" modeling influence on patients with regard to smoking suggests that the hypothesis of congruent behavior among key health professionals leading to their target groups" health behavioral changes in positive sense must be differentiated by locus of control. 


\section{References}

AAPHERD, 1971. Position statement: Smoking education the school's responsibility. Joumal of School Health, 8, 444-445.

Ball, K., 1970. Cigarette smoking and the responsibility of the physician. British Journal of Hospital Medicine, 865-866.

Bandura, A., 1977. Social learning theory. Prentice Hall: Englewood Cliffs.

Baric, L., 1974. Acquisition of the smoking habits and the model of smokers" careers. Journal of the Institute for Health Education, 1, 9-18.

Bates, R.C., 1983. Doctors who smoke. New York State Journal of Medicine, 13, 1294.

Baumgartner, K, 1982. Smoking cessation: physician - make a stand. Canadian Medical Association Journal, 126, 101-102.

Begley, C.M., 1982. The nurse's responsibility in relation to smoking and health. World of Irish Nursing, $8 / 9,6$.

Bewley, B.R., Day, I., Ide, L., 1976. Smoking by children in Great Britain. A literature review. Social Science Research Council. London.

Biddle, B.J., 1979. Role theory expectations, identities and behaviors. Academic Press: New York.

Blum, A., 1983. When "More doctors smoked Camels": cigarette advertising in the Journal. New York State Journal of Medicine, 13, 1347-1349.

Blum, A., 1986. Strategies to reduce cigarette salles: exercise taxes and beyond, Journal of the American Medical Association, 8, 1049-1050.

Board of Health, 1984. Smoking habits and attitudes toward smoking among students in the nursing institute. Series Statistics and Reviews, 4. Helsinki.

Boyer, E.M., 1976. Classroom teachers' perceived role in dental health education. Journal of Public Health Dentistry, 36, 4, 237-243.

Brachfield, N., 1978. Jogging: the physician"s role. Primary Cardiology, 49, 50-55.

Cavataio, D.M., 1984. Physicians themselves set good health models. Michigan Medicine, 1, 12.

CDC, Centers for Disease Control, 1976. Survey of health professionals on smoking and health: Summary report. US Departmentt of Health, Education and Welfare, Atlanta.

Chen, T.L. Rakip, W.R. 1974. Are teachers prepared to implement smoking education in the schools? Joumal of School Health, 44, 438-441.

Chen, T.L., Winder, A.E., 1985. Teachers' perceptions related to smoking education between 1973 and 1982. Journal of Drug Education, 2, 125-138.

Christensen, K.D., Egsmose, T., Otto, T., 1978. Negativ holdning blandt laeger og sygeplejersker til eksempletsbetydning. Sygeplejerskers $48,16-20$. (The negative attitude of physicians and nurses towards the exemplary role).

Clarke, M., Brooks, A ., Phillips, M. (No date, likely 1984). Nurses' smoking behavior. Research Report no. 3. Perspectives on patient care. Institute of Nursing Studies, University of Hull.

Coe, R.M., Brehm, H.P., 1971. Smoking habits of physicians and preventive care. HSMHA Health Reports 3, 217-221. 
Cooreman, J., Burghard, G., Prédizet, S., 1978. Ladolescent et le tabagïme. Responsabilité des parents et dés professeurs. Re'sultats d'une campagne de sensibilisation. Journal Medicale Strasbourg, $9,483-488$. (Youth and smoking: responsibilities of parents and teacher).

Craig, M. 1981. The health professional and alcoholism. New Zealand Nursing Journal, 2, 8. David, A.K. Boldt, J.S., 1980. A study of preventive health attitudes and behaviors in a family practice sotting. Journal of Family Practice, 1, 77-84.

Dekker, E., 1981. Smoking behavior in Dutch general practitioners, In: F. Fontana (Ed.) Tabacco $\theta$ Giovanni. Proceedings, Ventia. 297-303.

Delkker, E., 1982. De huisarts en het rookpatroon. In: Proceedings Symposium Foundation Smoking and Health. "Trekt de rook langzaam op?" Den Haag. (The general practitioner and the omoking pattern), p. 41-46.

Doll, R., 1983. Prospects for prevention. British Medical Journal, 286, 445-453.

Doll, A., Hill, A.B., 1952. Smoking among British physicians. British Medical Journal, 2, 1271.

Drouin, B., Oudot, $P_{\text {. }}$ Grillet, $Y$., Retrolle, F., 1984. Lutte et prevention anti-tabac. Revue Pneumonologie Clinique, 40, 237-242. (Anti-tobacco campaigns and prevention).

Dunning, AJ., 1985. De vrijheid om te roken. NRC June 13. (Froedom to smake).

Egsmose, T., 1977. The role of the health professional in smoking education. In: Steinfeld et al., $0 . c, 255-264$.

Egsmose, T., Stokholm, J. \& Egsmose, R., 1971. The attitude of Danish doctors toward a tobacco smoking control program.

Elmore, J.G., Kaplan, S.M. Meriano, D., Farquhar, J.W., 1985. Teaching physicians to practice what they will preach. Journal of the American Medical Association, 20, 2958-2959.

Eyres, S.Ji, 1973. Public health nursing section: report of the 1972 APHA smoking survey. American Journal of Public Health, 10, 846-852.

Festinger, L., 1957. A theory of cognitive dissonance. Row \& Peterson, New York.

Finn "P., 1981. Hey teach! Do you drink? Joumal of School Health, 10, 538-542.

Flanders, J.p., 1968. A review of research on imitative behavior. Psychological Bulletin 5, 316-337.

Fletcher, C.M. Horn, D. 1970. Smoking and health. WHO Chronicle, 8, 345-370.

Fox, A.A., 1978. Doctors, drink and disease. Lancet 731-732.

Fuhs, M.F. 1976. Smoking and the heart patient. Nursing Clinics of North Amorica, 2, 361-369.

Gastrin, G., 1981. Educational roles of health professionals. In: Fontana, F., Tabacco $\theta$ Giovanni. Proceedings, Venezla, 87.91 .

Glover, E.D., 1978. Modeling - a powertul change agent. Journal of School Health, 3, 175-176.

Golli, $V_{.}, 1979$. Inquiry into the opinions of secondary school teachers on smoking. Bulletin International Union against Tuberculosis, 1, 90-92.

Granieri, S., Burton, W. Webster, J., 1978. Tobacco health and the physician. Journal Chronical Diseases, 31, 499-500.

Gray, N., Daube, M., 1980. Guidelines for smoking control, Union Internationale contre le Cancer, Technical Reports nr. 52, Geneva. 
Halhuber, J., 1978. Raucherentwohnung: warum sind Aertzte so ineffektiv? Medizin und Klinik, 6. 203-207. (Smoking cessation: why are physicians so ineffective?)

Hanks, D.T., 1984. Physician modeling influences on patient smoking. North Texas State University, Denton. Dissertation.

Handy, M.E., Conway, M.E., 1978. Role theory perspectives for health professionals, Appleton/ Century Crofts: New York.

Higgins, C.W., Dunn, J.D., Warmack, D., 1983. Comparison of attitudes of smoking and nonsmoking teachers towards smoking education in schools and the health consequences of smoking. Health Education, 1, 24-27.

Hillier, S., 1973. Nurses" smoking habits. Postgraduate Medical Journal, 49, 693-694.

Hochbaum, G.M., 1980. Ethical dilemma's in health education. Health Education 2, 4-6.

Hoffman-Mennies, J., 1983. Smoking, one way to stop. American Journal of Nursing 1147-1148.

Hom, D., 1976. A model for the study of personal choice health behavior. International Journal of Health Education, 2, 89-98.

Jacka, E., Disler, P.E. Sayed, A.R., Watermeijer, G.S., Ross, W.F., 1984, Smaking habits of nurses. Curationis, $1,37-39$.

Jamrozik, K., Fowler, G., 1982. Anti-smoking education in Oxfordshire general practitioners. Journal of the Royal College of General Practitioners, 32, 179-183.

Kannas, L., Aare, L., Gillies, P., Gredler, B., Ledwith, F., Lorant, P., Rimpela, M., Wold, B., 1985. Health behavior in school-children. A WHO Cross National Survey. Mathods and materials of the 1983-1984 Study. In preparation. University of Jyväskylä, Department of Health Sciences.

Kellner, H., 1981. Das schlechte Beispiel der rauchenden Kollegen. Münchener Medizinisches Wochenschrift, 32, 36. (Smoking colleague"s bad extample).

Koski, G., Cullingford, G., Armstrong, B, 1978. The smoking habits and attitudes of nurses. Community Health Studies, 2, 27-31.

Kunze, M., Wood, M., 1984. Guidelines on smoking cessation. Union Internationale contre le Cancer Techical Report Series, Vol. 79, Geneva.

Lagerson, J., 1977. The exemplar role of professionals. In: Steinfeld, J. et al. (Eds.) Health consequences, education, cessation activities and governmental action. Proceedings Third World Conference on Smoking and Health. Washington, 429-432.

Lazenby, J., 1984. Nurses gain now image as non-smokers. RN ABC-News 4, 6-8.

Lichtenstein, E., Danaher, B.G., 1978. What can the physician do to assist the patient to stop smoking? In: Lichtenstein, E. Chronic Obstructive Lung Disease: clinical treatment and management. Mosby: St.Louis, 227-241.

Lipp, M.R., Benson, S.G., 1972. Physician use of marijuana, alcohol and tobacco. American Journal of Psychiatry, 5, 124-128.

Maes, L., 1985. Gezondheidsvoorlichting en -Opvoeding. In: Gids woor hel basisonderwijs. CED/ Samson, Brussel. 4611, 1-35. (Health Education).

Meichenbaum, 1971. Examination of model characteristics in reducing avoidance behavior. Journal of Personality and Social Psychology, 17, 298-307. 
Mettim; C., 1976. Peer and other influences on smoking. Joumal of School Health, 46, 9, 529-536.

Morra, M.E. Tisch-Knobl, 1983. Smokers, former smokers and non-smokers: a correlational study of nurses in Connecticut. Oncology Nursing Forum, 4, 40-45.

Muthearn, R.J., 1984. Smoking and ill health. Saudi-Arabian Medical Joumal, 3, 253-254.

Murray, M., Kiriluk, S., Swan, A.V., 1984. School characteristics and adolescent smoking. Joumal of Epidemiological and Community Health, 38, 167-172.

Najera, P. 1985, Smoking survoy among doctors in Spain. Paper WHO Meeting Southem European Action on Smoking. WHO/Euro and Ministry of Health and Consumer Altairs, Madrid.

Newman, $A, N_{n}, 1971$. How teachers see themselves in the exemplar role in smoking eduation as evidenced by their attitudes and practices. Joumal of School Health, 5, 275-279.

Noll, C.E., 1969. Health professionals and the problems of smoking and health. Report 3. Physicians behavior, beliefs and attitudes towards smoking and health. NORC. University of Chicago, Chicago.

Nutbeam, D., 1987. Smoking among primary and secondary schoolteachers. Health Education Journal, $1,14-18$.

Pederson, L.L., 1982. Compliance with physician advice to quit smoking:: a review of the literature. Preventive Medicine, 11, 71-84.

Philips, A.J., 1970. Smoking habits of professional groups in Canada. In: Union Internationale contre le Cancer. Public education about cancer. Union Internationale contre le Cancer, Technical Report Series Vol. 6, 34-37, Geneva.

Poussaint, A.F., Berman, S.H., Lichtenstein, E., 1966. The effect of the physicians' smoking on the trealment of smokers. Diseases of the Nervous System, 27, 539-543.

Poynter, A.G.; 1983. Alcohol and doctors. New Zealand Medical Journal, 96, 678.

Van Proosdij, C., 1957. Roken. Dissertation University of Amsterdam, Amsterdam. (Smoking).

Rabinowitz, H.S., 1975. Who health educales whom? International Joumal of Health Education, 183-188.

Rabinowitz, H.S., Zimmerli, W.H., 1976. Teaching learning mechanism in consumer health oducialton. Public Health Reports, 3, 211-217.

Raveel, E., 1985. Rookgewoonten bil verpleegkundigen van het Academisch Ziekenhuis te Gent. Paper Dienst Hygiene en Sociale Geneeskunde, Academisch Hospitaal, Universiteit van Gent. (Nurses' smoking habits at the Gont University Hospital).

Rosen, C., Astiley, M.J.i 1978. Smoking and the health professional; recognition and performance of reles; Canadian Journall of Public Health, 69, 399-406.

Salleras-Sanmarti, L., 1985. Smoking survey among health professionals in Catalunya, 1985. Paper WHO Meeting Souttion European Action on Smoking. Barcelona.

Scholes, M.E., 1982. Smoking and nurses. Health Bulletin, 2, 77-80.

Scholes, M.E., 1979. Smoking in hospital and health services premises: the role of the nurse in hospital and community. In: Smoking and Nurses. Proc. Action on Smoking and Health, Edinburgh, 24-27. 
Seip, A.K., 1982. Smoking habits among teachers in primary schools in Norway in 1977. Scandinavian Journal of Education Research, 26, 183-195. Shangold, M.M., 1979. The health care of physicians: Do as I say and not as I do. Joumal of Medical Education, 56, 668.

Shaw, M.E., Costanzo, P.R., 1981. Theories of social learning and imitation. In: Theories of Social Psychology. MoGraw Hill, New York, 41-67.

Smith, J. 1984. Prevention by example. Nursing Mirror, 13, 17-18.

Smith, L.W., Evans, R.I., Suomi, J.D. \& Friedman, L.A., 1975. Teachers as models in programs for school clental health: an evaluation of the toothkeeper. Journal of Public Health Dentistry. $35,2,75-80$.

Smits-van Sonsbeek, B., Hegger, W., 1976, GVO in het onderwijs. Jeugd en Samenleving, 9, 701715. (Health education in schools).

Spencer, J., 1984. The postal survey of nurses' smoking behavior. Instit. Nursing Research Report, nr.1, Hull.

Steinfeld, J., 1984. Smoking and thealth. Western Journal of Medicine, 6, 878-883.

Stoll. W., 1983. Weliness: practice what you preach. Postgraduate Medicine, 4 , 47.

Strecher, V., 1988. Personal communication.

Swenson, I., Dalton, J.A., 1983. A comparison of the knowledge and attitudes about smoking among nurses who never smoked, those who successfully stopped and those who currently smoke. International Nursing Studies, 3 , 163-170.

Visser "A.P., Viert, H.P. van de, Heine, E.J.H. ter, Winnubst, J.A.M., 1983. Rollen, persoonlijke en sociale invloeden op het gedrag. Boom, Meppel. (Roles, personal and social influences an behavior).

Wallace, P.G., Maines A.P., 1984. General practitioner and health promotion: what patients think. British Medical Journal, 289, 533-536.

Van de Weg, E., 1976. GVO deskundigen aan het woord. Huisarts en Wettenschap, 19, 119-121. (Health education professionals discussing).

Wells, K.B., Lewis, C.E., Leake, B., Ware, J.E., 1984. Do physicians practice what they preach? A study of physicians' health habits and counseling practices. Joumal of the American Medical Association, 20,2846-2848.

Wieberdink, J., Blaaderen-Stok, C.L. van., 1957. Bestrijding van longkanker door beperking van tabaksgebruik. Nederlands Tijdschrift voor Geneeskunde, 101, 1695-1700. (Cancer control through restriction of the use of tobacco).

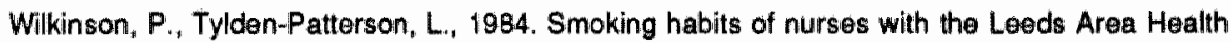
Authority. Health Education Journal, 4, 109-113.

Wilson. D., 1982. Smoking cessation strategies: the family physician's role. Canadian Family Physician, 28, 513-516.

Working Group of Nurses in Scotland, 1981. Smoking and Nurses. The next step. Proc. Scottish Committee of Action on Smoking and Health, Edinburgh.

World Health Organization, 1984. Guidelines for the conduct of tobacco smoking surveys among health professionals. Geneva. 
Chapter 4. Exemplary role

Yarom, D., Lerer, T., 1971. A survey of smoking habits among physicians in Israel. Harefiuah, 3, 150-151.

Yarrow, A., 1977. Key health professionals as educators. In: Steinfeld et al., o.c., 423-428. 


\section{Chapter 5.}

\section{Method and materials}

5.1 Framework of the study

5.2 Questionnaires

5.3 Samples

5.3.1 Schoolteachers

5.3.2 Community nurses

5.3.3 General practitioners

5.3.4 Non-response

5.3.5 Characteristics of the sample

5.4 Measurement by personall interview

5.5 Variables

5.6 Discussion

5.7 Summary 


\section{Introduction}

In this chapter the framework of the study is outlined; the development of the questionnaire is described, as well as sampling procedures, non-response and sample characteristics in comparison with the populations of Dutch professionals surveyed.

\subsection{Framework of the study}

In 1980, the Board of the Netherlands Oke Foundation (1) asked the then acting Dean of Health Sciences (2), to carry out a nationwide survey on health conceptions and health behaviors on the occasion of the First National Health Week to be held in August 1981. The Sclentific Committee of the Netherlands Oke Foundation and a research group (3) from the Universilty of Limburg formulated the design and conditions for the study. A picture of subjective health in the Netherlands anno 1981 was to be given, providing base-line data for health promotion activities to be implemented by the participants in the Foundation. The survey would be carried out among the population at large, and among groups having a special role in society, the so-called norm-groups, as the term was coined by Philipsen, i.e. primary care workers like community nurses, general practitioners and teachers were expected to fulfil a clearly positive role towards the general population's health.

On the other hand, those persons seriously ill or handicapped, retired, of out of work for a longer period than three months, were expected to report a less favourable subjective health. The same questionnaire was applied to random samples drawn from these groups and from the general population. The results were reported at the occasion of the 1981 National Health Week (Adriaanse, Drop, Halfens \& Philipsen, 1981). After the collection of the data for this first survey on a nationwide basis, which covered a large number of health related topics (see paragraph 5.2), it was felt that it would be worthwhile to add a longitudinal perspective to the study. A proposal for longitudinal analysis of health conceptions and -behavior with multiple surveys during the 1980's was developed by the research group. This proposal was entitled: the University of Limburg Health Panel (4) Study. In 1983, the Foundation Netherlands Oke and the University of Limburg financed a second survey (Halfens, Drop \& Philipsen, 1984). This time separate questionnaires were used for the population and the professional groups. Specific questionnaires were used for teachers, nurses and general practitioners, because in addition to questions on health conceptions and behavior, a set of questions on health educational aspects of their work settings were asked to the above-mentioned professional groups in order to be able to analyse the relationship between personal health conceptions and behaviors and professional performance in teaching, nursing and general practice settings. None of the other waves of surveys that were planned have been carried out until now, and it is questionnable whether the Health Panel Study as outlined by Philipsen c.s. can be financed in the near future. The need to gain knowledge about the trends of health conceptions and -behaviors and in the role of primary care workers and teachers ought to be health care policy priorities from which the nocessity of this type of research follows detinitely. 


\subsection{The development of the questionnaire: the 1981 and 1983 surveys}

The 1981 questionnaire (Adriaanse, Drop, Halfens \& Philipsen, $1981 \mathrm{~b}$ ) was designed by the research group, guided by the Foundation's Scientific Committee. It was a prestructured questionnaire to be used during personal interviews of the respondents. In addition to standard background information, lincluding variables as sex, age, education, urbanisation, political orientation, socio-economic status and relational status, the 1981 questionnaire consisted of sections on medical consumption, health conception, lifestyle, value of health, health locus of control, determinants of health, responsibility for health disease conception, physical complaints, smoking, alcohol consumption, exercise, safety, nutritional habits, safety, use of drugs, attitude towards medlical science, and coverage by insurance for health care expenses. An overview of the results, as well as the complete questionnaires can be found in Adriaanse et al., $1981 \mathrm{a} ; 1981 \mathrm{~b}$.

This description of the 1981 questionnaire is necessary because the 1983 questionnaire was developed on its basis. The decision to approach population and professional groups separately was made, because of the desirability of adding specific sections on professional performance with regard to health education. Only the sections on health conception and -behavior were identical for the three professional groups. Per profession, specific paragraphs on health educational aspects of professional performance were added to the surveys administered to teachers, nurses and general practitioners. These sections contained items regarding professional practice, professional locus of control, conceptions of health education, relative influence of different actors on population's health, position on prevention-cure continuum, exemplary role, attitudes on health care issues, role expectations and role performance concerning health education, cooperation, referral and activities with regard to health education. While questionnaires for general practitioners and community nurses were largely of a parallel structure, though wording obviously had to be different, teachers questionnaire contained a special paragraph on curricular aspects of health education, regarding the role of teachers and parents concerning childrens" health education, the subjects to be dealt with in the classroom and on the role of the school as social environment structuring health behavior.

The questionnaires were drafted by the researcher, discussed and tried out with practising professionals in teaching, nursing and general practice settings, as well as with researchers involved in research of school health education, community nursing and general practice. A concept-questionnaire was developed and tried out in video-taped interview sessions and Research and Marketing"s Studios in Heerlen, the Netherlands. On the basis of these experiences final versions of the three questionnaires were prepared by the researcher, supervised by Dr. Drop, project supervisor at the time. An overview of the results of the 1983 survey, as well as the complete questionnaires can be found in Adriaanse et al $1984 ; 1985$. 


\subsection{Samples}

Multistage stratified random samples were drawn from the teacher, community nursing and general practitioner population in the Netherlands. In general, the type of multistage stratified random sample practised by Research and Marketing B.V. consists of the following steps:

1. Selection of administrative unit (i.e. city, town or village), based on urbanisation per province.

2. Selection of addresses: per administrative unit the desired number of postal codes was drawn. The postal codes contain multiple addresses in a geographically limited area. House numbers were counted and divided by the desired number of addresses, thus resulting in the selection of each nth address in the sample to be interviewed.

3. Selection of persons: on arrival of the selected address, interviewer selected randomly a person being 21-64 years of age (or belonging to the profession).

The multistage random sampling method was applied to create the sample of the general population reported on by Halfens, Drop \& Philipsen, 1984. In chapter 7 part of the data collected by Halfens et al. are used to compare key health professionals' health behavior with the health behavior of the population at large. This procedure was only partially applicable to the professional groups, the sampling of which is described below.

\subsubsection{School teachers}

The first stages of the multistage stratified random sampling procedure described earlier was applied to create the teachers sample. Within the selected administrative units, schools were randomly chosen. Within schools, teachers of first through sixth grade were chosen by the interviewer on assignment by the field work organization, from the class to which the teacher should belong. In 1981, 387 were sampled, of 83 refused to cooperate, and five others could not be located. The response rate was $77 \%(\mathrm{~N}=299)$. In 1983, 135 teachers were sampled from the elementary school teachers who cooperated in $1981 ; 122$ of them could be located, out of whom 16 refused and five others did not attend the interview. Thus, the response rate in 1983 was $83 \%(N=101)$.

\subsubsection{Community nurses}

The first stage of the multistage stratified random sample was applied to select community nurses also. As a next step, through the use of the telephone directory, health care centers were listed and randomly selected. The interviewer then selected a respondent among the community nurses of the center. In 1981 a number of 109 community nurses was sampled, 20 of which refused while five others did not attend. The response rate was $77 \%(\mathrm{~N}=84)$. In 1983 , those community nurses collaborating in 1981 were asked to cooperate again. Seventy-one nurses could be located, ten of whom refused. In order to upgrade the sample to a comparable size of approximately 100 respondents, 39 other community nurses were sampled. Addition of the 1981 sample (response rate $86 \%(\mathrm{~N}=61)$ ) and the 1983 sample (response rate $100 \% ;(\mathrm{N}=39)$ ) provides a total 1983 sample of 100 community nurses. 


\subsubsection{General practitloners}

The first stage of the multistage stratified ramdom sample was applied to select general practitioners too. The number of of general practitioners per administrative unit was determined proportionally to the number of inhabitants. The Physician's Directory 19801981 was used to randomly select addresses among those physicians practising in a given administrative unit. In 1981, among 135 general practitioners 35 refused, 21 said to have no time, while five did not show up although appointments were made three times. The response rate in 1981 was $55 \%(N=74)$. In 1983 , those general practitioners collaborating in 1981 were asked to cooperate again; of 67 retrievable general practitioners, 18 refused, while two others did not attend. Thus, 48 '1981"-physicians were in the sample, response rate $70 \%$. In order to create a group of about 100 respondents, 88 general practitioners were sampled of whom 32 refused, while three questionnaires were not suitable for analysis. Addition of the 1981-sample, and the 1983-sample of general practitioners $(\mathrm{N}=53$; response rate $=60 \%)$ resulted in a 1983 sample of 100 general practitioners.

\subsubsection{Non-response}

The sample of teachers had relatively high response rates both in 1981 and 1983 , respectively $77 \%$ and $83 \%$. Resulting response rate in relation to the initial sample due to refusal and panel mortality is only $63 \%$. While in both cases respondents were selected randomly, no systematic bias is expected to have occurred among teachers. The community nurses' sample had an acceptable response rate in $1981(77 \%)$, but in 1983 colleagues were sampled in the same health centers, of whom no refusal percentage could be retrieved. The data concerning nurses might be biased in a sense that no optimal representation of different centers is guaranteed. However, the centers had been randomly selected initially. The general practitioners" sample was characterized by a low response rate: in 1981, it was only $55 \%$, and in $1983,70 \%$ of those collaborated. The newly sampled general practitioners' response rate was $60 \%$ only. The resulting response rate of approximately $65 \%$ is low but not uncommon.

Reasons for mon cooperation in the study, mentioned primarily by physicians, were: the overload of surveys going on at the time, the unmet request to be paid for the time spent on the interview to compensate the loss of income, and lastly, the view that this kind of surveying is not meaningful.

Although the samples cannot be considered to be completely representative for the profession they were drawn from, they were drawn randomly: data based on the responses from these samples can be considered to give reasonably reliable indications about the opinions and behaviors of these prolessional groups.

\subsubsection{Characteristics of the sample}

The average age of teachers was 36 years, of community nurses and general practitioners 39 years. Among teachers, $71 \%$ were married, while among community nurses $55 \%$ lived alone; $35 \%$ were married and $10 \%$ lived with partner(s). Among practitioners, $97 \%$ were married, while $3 \%$ lived alone. 
The average number of years in professional practice is 13.7 among teachers, 10 among community nurses and 11 among general practitioners.

Table 5.1 Comparison sample - population with regard to gender and age (percentages)

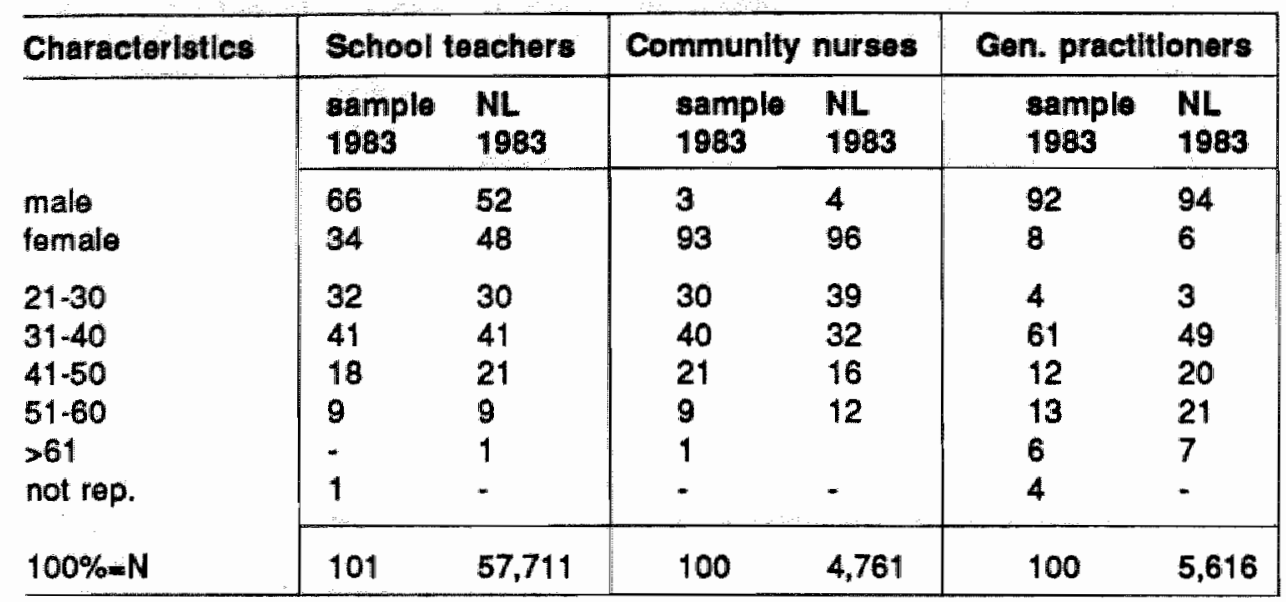

\section{Gender}

In Table 5.1 sex-and age-distribution of the samples drawn from the Dutch teachers, nurses and general practitioners as well as national figures, are given for 1983. While nursing as an almost exclusively female and general medicine a predominantly male profession, teaching is a mixed profession. The teachers' sample contains more males than the Dutch teacher population does. For nurses and physicians, the gender distribution shows no major differences with the national distribution figures.

In 1983 there were 29,959 male and 27,552 female elementary schoolteachers employed in the Netherlands, 164 male and 4,597 femalle community nurses, while there were 5,290 and 326 female general practitioners.

The sample contains somewhat more physicians under age 40 , and less middle aged and older physicians than the population. In the interpretation of the data it should be taken into account that the responding physicians are somewhat younger (average age 39) than the general practitioners' population in the Netherlands was in 1983. Teachers sample's age distribution matches the teachers' population's age distribution quite well. As for community nurses' age distribution it should be noted that age classes 1 and 3 are somewhat underrepresented; age classe $31-40$ is slightly overrepresented. The focus is on inter- and intra-professional differences, not on age and gender differences. Numbers of female physicians and male nurses are too small for conclusions. 


\subsection{Measurement by personal Interview}

The interviews were carried out in the period of 21 st of March until 30th of June 1983, by 69 interviewers trained by Research and Marketing, and instructed by the researcher during regionally organized meetings. The quality of their work was checked with regard to the application of sampling instructions, interviewing instructions and completeness of the questionnaires filled out. The data were coded inasfar as necessary and computerized at the Medical and Social Infocenter of the University of Limburg. The data were collected under application of the International Code of Practice, Marketing and Social Research, ICC/Egomar.

In view of the broad range of health-related topics which would be surveyed, oral interviewing was considered to be the best way of approaching professionals. Though costly and eventually raising the percentage of socially desirable answers to questions, oral interviewing would have the advantage of a higher response rate. The questionnaires had a total of about 35 pages, and several questions needed instruction by the interviewer.

Interviewing respondents about personal health habits may trigger more socially desirable answers than would be given in the absence of an interviewer, i.e. by the use of mailed questionnaires, thus giving the best guarantee for anonimity: However, response rates would be too low given the number of questionnaires that were addressed to prolessionals especially to general practitioners yearly, which, in addition to other information overload, caused a survey-fatigue. Fifty to $60 \%$ is high presently, while personal interviews can obtain rates between 80 and $100 \%$ (Gadourek, 1976).

Advantages of survey method are: the rapid collection of a great number of data among a great number of people in a relatively valid and reliable manner. Disadvantages can be that survey information does not penetrate very deeply below the surface; secondly surveys are demanding time and money, and finally surveys create special events in the ordinary life of the respondent and therefore can measure artifacts (Kerlinger, 1973). As eloquently stated by Philipsen in his introductory chapter (Adriaanse et al., 1981), this survey has the power of collecting many things like in a trawlernet instead of having the precision of a rod. Using the rod, one does not get information about all the fish swimming in the sea, but - if one is lucky - a few of the specific species aimed at get hooked. As our aim was to collect data concerning health conceptions and -behavior, having a broad range, the survey approach was chosen.

Tobacco and alcohol consumption are underreported usually (Philipsen, Knibbe \& Van Reek, 1983; Todd, 1978). No data are available with regard to profession-specific underreporting.

Physiological controls as are available to have a check on tobacco or alcohol consumption. These can only be applied in small scale experimental settings and not in large surveys. Access to professional people might be easier when the interviewing would be done by a peer, though this might introduce other biases concerning desirable professional behavior. Long ago it was already argued that 40 to $50 \%$ were acceptable response rates for population surveys (Gadourek, 1976). In the two decades following Gadourek's observation, survey-fatigue emerged as a phenomenon due to the great 
number of polls. In that light the rates obtained in this investigation can be considered as acceptable in the 1983 situation.

\subsection{Variables}

Main variables in the investigation are health education, health behavior ${ }_{n}$ and perception of the exemplary role. In addition background variables were integrated in the questionnaire. The statistical characteristics of the main variables are presented in the pertaining chapters 6 to 8 . The operationalization of these variables is outlined there and then.

\subsection{Discussion}

It is important to note here that samples were drawn from the professional groups as these were composed in reality, in 1983. As shown in table 5.1, the division of gender in the three groups was quite different. While nurses are predominantly female, doctors are predominantly male. Elementary schoolteachers are distributed much more evenly. In the analyses presented in the chapters to tollow, the focus is not on sex differences, but on differences between the professional groups. Would the central research questions have been focused on intraprofessional sex differences, then another design would have been needed, involving the stratification of the samples by gender, in order to obtain comparable groups of male and female professionals. However, that was not the focus of this research.

\subsection{Summary}

The history of the Health Panel Study was briefly outlined in order to explain the development of the questionnaires used in 1983 to measure health conceptions, health behaviors and health educational aspects in the work of schoolteachers, community nurses, and general practitioners. Three samples of 100 respondents were drawn from the three professionals groups on the basis of a multi-stage stratified random technique for the first stages, adapted to profession-specific circumstances for the last stages. Considerable non-response could have influenced the results of the survey. Genderwise samples do not differ greatly from the Dutch population of nurses and physicians; the teachers' sample contains more males than the population of teachers in the Netherlands. The general practitioners' sample contained more young and older but less middle-aged physicians than the population of general practitioners. (Dis)advantages of the personal interview technique are discussed. 


\section{Notes}

1. Organizations participating in the Netherlands Oke Foundation were the Nutrition Education Bureau in The Hague, the Union of Dutch Disease Insurance Funds in Zeist, the Dutch Sports Federation in The Hague, the Federation of National Health Care Cost Insurance Companies in Bunnik, the Safety Institute in Amsterdam, the National Cross Union in Bunnik, the League against Alcohol Abuse in The Hague, and the Smoking and Public Health Foundation in The Hague.

2. Prof.Dr. Hans Philipsen, Dean of the Faculty of Health Sciences 1980-1983, then Head of the Department of Medical Sociology, now Head of the Department of Nursing Science, Faculty of Health Science, University of Limburg.

3. Members of the research group: Dr. Maria J.Drop and Dr. Hans Philipsen, Department of Medical Sociology; Drs. Hans Adriaanse and Drs. Ruud Halfens, Department of Health Education, University of Limburg, Maastricht, The Netherlands.

4. Panel : a study design involving reinterview of a series of diaries or questionnaires with the same sample or respondents (or household units) at two or more different times (Sudman, 1981).

5. Teachers: data obtained from Centraal Bureau voor de Statistiek (CBS, 1984) Nurses: data obtained from NIVEL, Utrecht (L.Hingstman, personal communication) Physicians: data obtained from NIVEL, Utrecht (L.Hingstman, personal communication).

6. Data will be made available to the Steinmetz Archives, Amsterdam for public accesss after five years from data collection. 


\section{References}

Adriaanse "H., Drop, M.J., Haltens, R., Philipsen, $H_{\text {... }}$ 1981a. Leeft Nederland Oke? Verslag wan een onderzoek naar de beleving, opvattingen en gedragingen inzake gezondheid, uitgevoerd door de Aijksuniversiteit Limburg, Stichting Nederland Ok6, Zeist. (Is the Dutch life-style o.k.? A report on the experiences, conceptions and behaviors concerning health).

Adriaanse, $H_{.}$, Drop, M.J., Halfens, $R$., Philipsen, $H_{v i}$ 1981b. Leeft Nederland Oke? Vragenlijsten en frequentieverdelingen van de steekproeven. Maastricht. (Is the Dutch life-style o.k.? Questioninaires and frequency distribution).

Adriaanse, H. Drop, M.J., Mey, K. de, Verboom, W. Witte, L.J. de, 1985. Gezondheidsopvalting en Beroepsuitoefening. (B). GVO-cahier no. 13. Capaciteitsgroep Geazondheidsvoortichting on -Opvoeding, Rijksuniversiteft Limburg, Masastricht. (Health conceptions and professional performance, report B).

Adriaanse, H., Mey, K. de, Verboom, W., Witte, L.J. de, 1984, Gezondheidsopvatting en beroepsuitoefening. (A). Vragenlijsten en frequentieverdelingen. Capaciteitsgroep Gezondheidsvoorlichting en -Opvoeding. Rijksuniversiteit Limburg. Maastricht. (Health conceptions and professional performance: report A. Questionnaires and frequencies).

CBS (Centraal Bureau woor de Statistiek), 1984. Instroom, herintreding en doorstroom van leerkrachten in het gewoon lager onderwijs, buitengewoon onderwijs en voortgezet onderwijs. CBS, Voorburg. (Influx, reentry and leave of teachers in elementary education. special education and secondary education).

Gadourek, I., 1976. Sociologische onderzoekstechnieken. Van Loghum Slaterus, Deventer. (Sociological methodology).

Halfens, A., Drop, M.J., Philipsen, H., 1984. Leefwijzen en subjektieve gezondheid van een panel uit de Nederlandse bevolking. Rijksuniversiteit Limburg, Maastricht. (Life-styles and subjective health of a panel from the Dutch population).

Hingstman, L., 1986. Personal communication. Unpublished data from the Netherlands Institute for first line health care, NIVEL: Utrecht.

Kerlinger, F.N. 1973. Foundations of behavioral research. Holt, Rinehart and Winston: London.

Philipsen, $H_{*}$ Knibbe, R.A., Reek, J. van (1983). Alcohol consumption in the Nethertands as social phenomenon. In: Hermus, R.J.J. (Ed.) Alcohol, health and society. Wageningen, 1983, p. $53-70$.

Sudman, S. (Ed.), 1981. Health survey research methods. National Center for Health Services Pesearch. US Dept. HHS, Washington DC.

Todd, G.F., 1978. Cigarette cansumption per adult of each sex in various countries. Joumal of Epidemiology and Community Health, 32, 289-293. 


\section{Chapter 6.}

\section{Health education: results}

6.1 Introduction: development of health education competencies

6.2 Operationalization of health education

6.3 Results

6.3.1 Health education perception in the actual situation

6.3.2 Health education activities and collaboration with regard to health education activities

6.3.3 Health education perception in the desired situation

6.3.4 A typology of health education perceptions

6.4 Discussion

6.4.1 Method

6.4.2 Comparison with previous research

6.5 Conclusions

6.6 Summary 


\subsection{Introduction: development of health education competencles}

The first central question which was raised at the end of chapter 1 was: how do key health professionals perceive health educational aspects of their tasks?

In this chapter health educational aspects of the work in the teaching, nursing and medical practice setting will be deali with. As was shown in chapter 2, the identity of health education can be conceptualized in many different ways. In this study two approaches were followed simultaneously, i.e. firstly the measurement of the health education function, in terms of the perceived importance of health educational aspects in the practical worksetting, and secondly in terms of health education activities. The two approaches are described in the next section. Then, in section 6.2 , the operation alization of health education in this study is described, followed by the presentation of the results of the measurements of health education in the actual and desired situation. $A$ typology of health education perceptions is proposed. Health education activities are presented, followed by a discussion and some conclusions. The lit erature referred to is listed as references at the end of chapter 2.

In the first place, health ducation competencies were measured in a general sense. This list of competencies contains ten main groups of items, e.g. planning for health education, implementation, coordination and evaluation. This delineation of the health education function in society is broad on the one hand because it is not tied to a specific profession or even sector, but to the health education function as it is performed in respective societal sectors, within schools, industry, health care, sports organizations etc., by either health education professionals or lay persons. On the other hand the underpinning of the list of health education competencies is fairly detailed, because it is built on sets of knowledge and skills-elements representing 51 testable competencies. These competencies were originally developed as a planning instrument for curriculum development at the University of Limburg in 1982 (Simonds, Rouwenhorst et al., 1982). The basis of the list of health education competencies was developed using the knowledge, experiences and function descriptions existing in the Netherlands in the early 1980 's. Though the process was inspired by the American Role Delineation Project (Henderson, 1981), the Dutch development of competencies for health education started from scratch, inventory and systematizing knowledge and experiences present. A first draft was reviewed by representatives from the health field (school health, health services, mental health, community nursing, health policy) and with related academic disciplines presented in a curriculum development group existing at the time at the University of Limburg's Faculty of Health Sciences. The version used in this investigation was the first one (Simonds et al., 1982). After the completion of the data collection for this investigation, the list of health education competencies was revised in Simonds, Nijhuis, DiPletro \& Adriaanse, 1984. The list of competencies was intended for multiple uses, i.e. as a steering mechanism for the learning process at the level of the individual student (formative use), as a set of end-terms to test the perception of student capabilities during the four year program and as checklist for curriculum planning. As an adequate listing of competencles not only serves training but also practice, the list of competencies was also meant to be used among professionals in relevant fields to 
measure their perception of health educational aspects of their work, thus bridging fields of academic preparation and professional performance.

Secondly, health education in the teaching, nursing and general practice setting was measured by questions regarding the performance of a number of activities usually considered to be primarily of health educational nature, e.g. the dissemination of information on specific health problems by leaflets, contribute to self-help initiatives or arrange health care premisses in such a way as to optimize their educational function. This measurement of health education activities was largely based upon identical instruments among nurses and physicians; among teachers, however, other instruments had to be used, because of the differences existing between the teaching and the health care work settings.

\subsection{Operationalization of health education}

The health education function has been operationalized in the next ten main categories:

I. Creating conditions for development of health education

II. Assessment of possibilities for health education

III. Planning for health education

IV. Implementation

V. Preparing/co-developing health education policy

VI. Coordination for health education

VII. Developing relationships

VIII. Guidance of other workers

IX. Evaluation

$X$. Research

These ten main categories were based on the 52 competencies, involving 210 knowledge- and skills-elements, resulting from the role delineation process (Simonds et al., 1982). As is shown in chapter 2, health education is a developing part of the work of health care providers and educators. Therefore, questions have been asked about the actual situation and the desired situation with regard to health education in their work settings.

Firstly, respondents were asked to rate the importance of these competencies in their actual work on a four-point scale; secondly, they were asked to what extent they would like to increase, stabilize or decrease the attention given to the diverse health educational aspects of their work.

In addition to the perception of health educational aspects of their work, the three professional groups were asked about concrete health education activities they had been carrying out. Teachers were asked about health education activities carried out in the classroom, attention given to a number of health education themes (e.g. nutrition, salety at home and at school, sexuality, hygiene, environmental health, etc.). Other questions pertained to extracurricular health education activities, l.e. to school regulations and organization (e.g. regulations of smoking by children around school, dental hygiene at school, safety around school) and about cooperation with other professionals with regard to health education. 
Community nurses and general practitioners were asked comparable, but not identical questions on health education activities, and cooperation with regard to health education. Health education activities were measured by asking respondents to indicate whether they themselves carried out activities such as distribution of leaflets, patients diaries, whether they organized a patient library or arranged the waiting room as an educational tool, whether they participated in external health activities etc. Cooperation with regard to health education was measured by submitting a list of possible professional and lay counterparts involving school physician and nurse, dentist, health educator, hospital social work, patient organizations etc. Professionals were asked to indicate their involvement in these activities over the last year.

\subsection{Results}

In order to avoid the loss of information, the data presentation in the next sections is organized as follows. Firstly, the perception of health education in the actual and desired situation is presented in terms of frequencies and means per competency for each professional group. Secondly, the variables health education activities and collaboration with regard to health education are presented. Thirdly, the health education competencies are presented again, dichotomised this time by the level of health education activities, thus allowing a check on the consistency of reporting on activities and perception. Fourthly, sumscores are calculated resulting in 2 overall measures of a. the perception of health education in the actual, and b. in the desired situation.

\subsubsection{Health education perception In the actual situation}

In table 6.1 the proportions of professionals within the three groups that rated given health education competencies as either important or very important in the actual situation of their practice, are presented for each competency.

Table 6.1 Health education perception" in the actual situation

\begin{tabular}{|l|l|l|l|}
\hline Health education competencles & \multicolumn{3}{l|}{ Health education in the actual situation } \\
\hline & School & Community & General \\
& teachers & nurses & practitioners \\
& $N=101$ & $N=100$ & $N=100$ \\
1. Creating conditions & 66 & 48 & 29 \\
2. Assessinent & 61 & 61 & 27 \\
3. Planning & 53 & 55 & 18 \\
4. Implementation & 76 & 75 & 47 \\
5. Policy development & 55 & 51 & 19 \\
6. Coordination & 60 & 43 & 13 \\
7. Developing relationships & 58 & 58 & 21 \\
8. Counseling and guidance & 47 & 48 & 18 \\
9. Evaluation & 65 & 62 & 13 \\
10. Research & 51 & 37 & 18 \\
\hline
\end{tabular}

- The cells represent percentages of the professional groups indicat ing that the item was (very) 
Over half of the teachers considered all competencies but one, l.e. counseling and guidance, to be (very) important in their actual work. Implementation was considered the most important aspect of health education for all three protessional groups. Sizeable proportions of the teachers, varying from $24 \%$ to $49 \%$ did not consider the health education competencies as (very) important.

Among community nurses, the perception of the importance of the health education competencies was very much the same as among the schoolteachers, only 'coordination' and 'research' were considered to be clearly less important.

General practitioners for the greater part appeared to have a different perspective on health education in their work. The only commonality with the teachers and the nurses is that among them too "implementation" was considered as (very) important by the largest proportion. Only small proportions of general practitioners, however, varying from $13 \%$ to $29 \%$, perceive health educiation competencies as being important in their actual work. It is striking that planning, coordination, counseling and guidance, and evaluation and research all are considered as not or just somewhat important by far most physicians in the survey.

After the inspection of the percented frequencies, the means per competency per professional group are presented and tested by means of analysis of variance (see table 6.2).

Table 6.2 Health education perception in the actual situation, tested means per competency per professional group

\begin{tabular}{|l|l|l|l|l|}
\hline $\begin{array}{l}\text { Health Education } \\
\text { Competency }\end{array}$ & $\begin{array}{l}\text { School- } \\
\text { teachers } \\
\mathrm{N}=101\end{array}$ & $\begin{array}{l}\text { Community } \\
\text { nurses } \\
\mathrm{N}=100\end{array}$ & $\begin{array}{l}\text { General } \\
\text { pract. } \\
\mathrm{N}=100\end{array}$ & F-values \\
\hline 1.Creating conditions & 2.75 & 2.65 & 1.99 & $16.0^{* * *}$ \\
2.Assessment & 2.62 & 2.61 & 1.95 & $14.0^{* * *}$ \\
3.Planning & 2.44 & 2.51 & 1.55 & $23.7^{* * *}$ \\
4.Implementation & 2.90 & 3.10 & 2.39 & $11.8^{* * *}$ \\
5.Policy development & 2.89 & 2.45 & 1.64 & $20.5^{* * *}$ \\
6.Coordination & 2.45 & 2.27 & 1.48 & $23.2^{* * *}$ \\
7.Developing relationships & 2.47 & 2.54 & 1.70 & $16.5^{* * *}$ \\
8.Counseling and guidance & 2.86 & 2.39 & 1.58 & $15.7^{* * *}$ \\
9.Evaluation & 2.70 & 2.58 & 1.48 & $40.5^{* * *}$ \\
10.Research & 2.50 & 2.15 & 1.53 & $22.4^{* * * *}$ \\
\hline
\end{tabular}

The average scores of the health education competencies in their actual work appear to differ significantly between schoolteachers, community nurses and general practitioners, with regard to all competencies. It can be seen more precisely now that schoolteachers and community nurses consider all items as more important in their actual work setting than do general practitioners. School teachers consider all competencies as being more important, than do community nurses, with the exception of planning implementation and the development of relationships. Nurses considered these latter competencies to be more important in their daily work than do both schoolteachers and general practitioners. 
In general, if can be observed in table 6.2 that schoolteachers consider the whole range of health educational aspects of their work as being important. Although to a somewhat lesser extent and with the exception of the research competency, which they value less and of planning, implementation and developing relationships, which they value more, community nurses appear to have a similar perception of health educational aspects in their work. General practitioners, on the contrary, have a different perception of the health educational aspects of their work. For the most among these professionals only the implementation of health education is important in their actual practice. Other health educational aspects of general practice are considered to be important in their daily work by considerably smaller proportions than among the other two professional groups.

\subsubsection{Health education activities}

In order to get a better grip on health education in the work settings, not only perceptions of health education, but also concrete activities have been asked about. This variable allows us to give a clearer picture of health education in the work of the key health professionals. It also provides a measure of internal validity for the concept introduced in this chapter: the perception of health educational aspects in the work settings in the actual situation.

Respondents were asked about health education activities carried out during the last year.

\section{Health education activities}

Health education activities had to be measured differently among schoolteachers on the one hand, and community nurses and general practitioners on the other hand due to the differences in worksettings. Therefore, no systematic interprofessional comparison can be made other than at the level of the total number of these activities. The variable "health education activities" thus indicates the self reported degree of involvement in concrete health education delivery. The distribution of this participation is presented in appendix $\mathrm{A}$ and $\mathrm{B}$.

In table 6.3 the distribution of health education activities is summarized in three categories and basic statistics are given. Analysis of variance showed that there are no significant differences between the professional groups, means differing no more than 3 . Gender nor age had a significant impact. 
Table 6.3 Health education activities reported to be carried out during the last year: statistical characteristics

\begin{tabular}{|l|l|l|l|l|}
\hline \multirow{2}{*}{ Number of activities } & \multicolumn{3}{|c|}{ Professional group (percentages) } \\
\cline { 2 - 5 } & School & Community & General & All \\
& teachers & nurses & pract. & professionals \\
few (1-4) & 34 & 15 & 24 & 29 \\
average (5-7) & 23 & 25 & 43 & 36 \\
many (8-13) & 43 & 60 & 33 & 33 \\
median & 7.0 & 6.0 & 6.0 & 6.0 \\
standard deviation & 4.0 & 3.1 & 2.5 & 3.2 \\
skewness & -.29 & .01 & -.45 & -.27 \\
mean & 5.8 & 5.9 & 6.1 & 6.0 \\
\hline
\end{tabular}

As a third step the perception of health education scores of all professionals were dichotomized by level of health education activity indicated. In order to check consistency between perceptions and level of activity, mean scores on each competency were tested for significance by means of analysis of variance (see table 6.4).

Table 6.4 Health education perception in the actual situation: means per competency over all professionals, dichotomized by the level of health education activity

\begin{tabular}{|c|c|c|c|}
\hline $\begin{array}{l}\text { Health Educatlon } \\
\text { Competency }\end{array}$ & $\begin{array}{l}\text { Hea } \\
\text { low }\end{array}$ & $\begin{array}{l}\text { tion } \\
\text { high }\end{array}$ & $\begin{array}{l}\text { F-values activity } \\
\text { between group }\end{array}$ \\
\hline 1.Creating conditions & 2.24 & 2.66 & $13.9^{* * *}$ \\
\hline 2.Assessment & 2.23 & 2.54 & $8.4^{* *}$ \\
\hline 3.Planning & 2.02 & 2.25 & $4.1^{*}$ \\
\hline 4.Implementation & 2.66 & 2.85 & 2.7 \\
\hline 5.Policy development & 1.97 & 2.35 & $10.5^{* * *}$ \\
\hline 6.Coordination & 1.83 & 2.19 & $8.6^{* *}$ \\
\hline 7.Developing relationships & 2.05 & 2.37 & $7.6^{* *}$ \\
\hline 8.Counseling and guidance & 1.89 & 2.27 & $9.3^{* *}$ \\
\hline 9. Evaluation & 2.09 & 2.37 & $5.0^{*}$ \\
\hline 10. Research & 1.83 & 2.20 & $8.6^{* *}$ \\
\hline
\end{tabular}

As it appears, health education is perceived as more important in the actual work setting of those key health professionals who report higher health education activities. This is true for all competencies, except for implementation of health education where the borderline difference of the average scores is only .19 which is only significant at the $p=.10$ level.

From the significance of all competencies it can be concluded that the perception of health education in the actual work is positively related to the level of health education activity as reported by Dutch key health professionals. 
As a fourth step, the data concerning the perception of health education in the actual work setting are summarized by the sumscore of the ten competencies, thus representing their importance as a number on a scale ranging from 10 to 40 points. It is a logical step to summarize this variable statistically in this way because the items can be considered to represent one factor with a high reliability (see results of factor and realiability analysis (Cronbach"s alpha $>.90$ ) in table 6.5 .

Table 6.5 Health education perception in the actual situation Factor analysis and reliabilities

\section{Varlable}

1. Creating conditions

2. Assessment

3. Planning

4. Implementation

5. Policy development

6. Coordination

7. Developing relationships

8. Counseling and guidance

9. Evaluation

10. Research

Elgen value

Percentage of variance explained Cronbach's alpha

\begin{tabular}{|c|c|c|}
\hline \multicolumn{2}{|c|}{ Communalitles } \\
\hline $\begin{array}{l}\text { School- } \\
\text { teachers } \\
\text { Commun. }\end{array}$ & $\begin{array}{l}\text { Comm. } \\
\text { nurses } \\
\text { Commun. }\end{array}$ & $\begin{array}{l}\text { General } \\
\text { pract. } \\
\text { Commun. }\end{array}$ \\
\hline .54 & .55 & .49 \\
.60 & .60 & .69 \\
.65 & .67 & .59 \\
.55 & .50 & .52 \\
.60 & .56 & .52 \\
.66 & .67 & .62 \\
.62 & .74 & .63 \\
.54 & .52 & .55 \\
.64 & .66 & .56 \\
.54 & .50 & .39 \\
5.94 & 5.96 & 5.56 \\
59.4 & 59.6 & 55.6 \\
.92 & .91 & .92 \\
\hline
\end{tabular}

The Health Education Perception in the Actual situation scores thus calculated will be abbreviated as HEP-A (variable name), its statistical characteristics are given in table 6.6 .

Table 6.6 Health eduation perception in actual situation: statistical characteristics

\begin{tabular}{|l|c|c|c|}
\hline & $\begin{array}{l}\text { School- } \\
\text { teachers }\end{array}$ & $\begin{array}{l}\text { Community } \\
\text { nurses }\end{array}$ & $\begin{array}{l}\text { General } \\
\text { practitioners }\end{array}$ \\
\cline { 2 - 4 } Median & 27.0 & 26.0 & 16.0 \\
Standard deviation & 6.9 & 7.7 & 6.1 \\
Skewness & -.26 & -.27 & .56 \\
Mean & 25.95 & 24.64 & 17.53 \\
\hline
\end{tabular}

Schoolteachers and community nurses do percelve health education as more important in their actual work setting than do general practitioners. F-ratio between professional groups is $33.78^{* * * *}$. 


\subsubsection{Health education perception In the desired situation}

In this paragraph, the precented frequencies of the health education perception in the desired situation (HEP-D), its mean scores, tested for differences between the protessional groups, the averages found among those professionals reporting either high or low levels of health education activity, the results of factor and reliability analysis as well as the statistical characteristics of the constructed sumscore are presented in the same way as this was done for the perception of health education in the actual situation as described sub 6.3.1.

In table 6.7 the percentages of the professionals are presented: in the first column the percentage wishing to diminish their attention to the given health education aspect of their work those, willing to keep it like it is "and, finally, the percentage of those willing to give more attention to the health education item concerned.

Table 6.7 Health education Competencies: Attention for health educational aspects in teaching, nursing, and general practice in the desired situation*

Competencles

1. Creating conditions

2. Assessment

3. Planning

4. Implementation

5. Policy development

6. Coordination

7. Developing relationships

8. Counseling and guidance

9. Evaluation

10. Research

Average percentage

\begin{tabular}{|rrr|rrr|rrr|}
\multicolumn{2}{|c}{$\begin{array}{c}\text { School } \\
\text { teachers }\end{array}$} & \multicolumn{3}{c}{$\begin{array}{c}\text { Community } \\
\text { nurses }\end{array}$} & \multicolumn{3}{c|}{$\begin{array}{c}\text { General } \\
\text { practitioners }\end{array}$} \\
\hline 8 & 49 & 42 & 8 & 41 & 51 & 16 & 50 & 35 \\
9 & 49 & 42 & 7 & 45 & 48 & 10 & 57 & 33 \\
21 & 35 & 43 & 14 & 44 & 42 & 29 & 49 & 22 \\
6 & 35 & 58 & 11 & 37 & 52 & 15 & 47 & 38 \\
24 & 37 & 39 & 20 & 44 & 36 & 27 & 55 & 18 \\
23 & 42 & 34 & 22 & 53 & 25 & 32 & 51 & 17 \\
16 & 45 & 38 & 11 & 52 & 37 & 19 & 50 & 31 \\
28 & 44 & 28 & 16 & 51 & 33 & 22 & 59 & 19 \\
15 & 42 & 43 & 13 & 46 & 41 & 26 & 48 & 26 \\
22 & 37 & 40 & 18 & 55 & 27 & 31 & 44 & 26 \\
17 & 42 & 41 & 15 & 47 & 39 & 23 & 51 & 27 \\
\hline
\end{tabular}

* The cells represent percentages of the professional groups indicating their wish to give less (L), equal ( $E$ ) or more ( $M$ ) attention to the health education items in their future work.

N.B. $N=100$ per group, at some items slightly lower due to non-response.

Among the schoolteachers considerable proportions, ranging from $35 \%$ to $49 \%$ want to keep attention for health educational aspects in their work as it is. On the other hand there are also considerable proportions, ranging between $38 \%$ and $58 \%$ who want to increase attention for health educational aspects especially with regard to implementation (58\%). Only a small proportion of the schoolteachers want to cut down on any health educational aspect of their work. 
Among community nurses even more sizeable groups than among schoolteachers want to keep their attention for health education as it is: percentages range from $37 \%$ to $55 \%$. As among teachers, the desire to increase attention for health educational aspects exists among many more nurses than the desire to decrease attention, potential increases ranging between $25 \%$ and $52 \%$, while potential decreases range between $7 \%$ and $22 \%$.

Among general practitioners the greatest proportion aims at keeping their attention for health education equal, percentages ranging between $44 \%$ and $57 \%$. Considerable proportions of general practitioners want to decrease attention for health educational aspects in their work in the future. With regard to half of the health educational aspects this proportion is bigger than the proportion willing to increase its attention for the health educational aspects concerned.

On the whole, considering that those willing to keep the extent to which attention is given to health educational aspects do not add to health education in the actual situation, it can be concluded from table 6.7, on the basis of the differences between the 'more' and 'less' proportions, that teachers and nurses want to increase their attention for health education considerably (on the average, $24 \%$ in both cases), while the net advancement of attention for health education among general practitioners is only little $(+4 \%$ on the average).

After this first inspection of the percented frequencies, the mean scores per competencies per professional group are presented and tested by means of analysis of variance (see table 6.8). The scores ranging from 1 (meaning one desires to give less attention to the health education competency) to 5 (meaning (much) more attention for that aspect).

Table 6.8 Health education perception in the desired situation: means per competency per professional group (Score 1-5)

\begin{tabular}{|l|l|l|l|l|}
\hline $\begin{array}{l}\text { Health Education } \\
\text { Competencles }\end{array}$ & $\begin{array}{l}\text { School- } \\
\text { teachers }\end{array}$ & $\begin{array}{l}\text { Community } \\
\text { nurses }\end{array}$ & $\begin{array}{l}\text { General } \\
\text { pract. }\end{array}$ & F-values \\
\cline { 2 - 5 } 1.Creating conditions & 3.31 & 3.47 & 3.11 & 1.9 \\
2.Assessment & 3.34 & 3.51 & 3.23 & 2.6 \\
3.Planning & 3.20 & 3.34 & 2.77 & $4.8^{* *}$ \\
4.lmplementation & 3.64 & 3.53 & 3.17 & $5.9^{* *}$ \\
5.Pollcy development & 3.15 & 3.06 & 2.87 & 1.6 \\
6.Coordination & 3.04 & 2.93 & 2.62 & 2.5 \\
7.Develloping relationships & 3.22 & 3.16 & 3.15 & 0.2 \\
B.Counseling and guidance & 2.95 & 3.02 & 2.96 & 0.1 \\
9.Evaluation & 3.21 & 3.31 & 2.91 & 2.5 \\
10. Pesearch & 3.15 & 2.98 & 2.86 & 1.9 \\
\hline
\end{tabular}

Although it can be seen that most competencies on the average are subject to little change whatsoever, it is clear that schoolteachers and community nurses agree on slight reinforcement of their attention for virtually all health education competencies. Differences between these two professional groups do not exceed.17. Physicians consistently underscore the two other professional groups, but these differences are significant only with regard to planning and implementation. 
As a third step the average scores per competency per professional group are presented, dichotomized by the - either low or high - level of self reported health education activity. Unlike when considering health education perception in the actual situation in relation to health education activity, there is no compelling reason for this variable to be related positively to health education in the desired situation. Wishes concerning attention for health educational aspects of work in the future can be independent of the current importance of health education in the professional performance. Nevertheless it is useful to inspect this relationship and assess with regard to what competencies those professionals already performing at a high level of health education activities, desire to elaborate. In table 6.9 the average scores per competency by dichotomized health education activity level are presented.

Table 6.9 Health education perception in the desired situation; means per competency over all professionals dichotomized by the level of health education activity

Health Education
Competency

1.Creating conditions

2.Assessment

3.Planning

4.Implementation

5.Policy development

6.Coordination

7.Developing relationships

8.Counseling and guidance

9. Evaluation

10. Research

\begin{tabular}{|c|c|c|}
\hline \multicolumn{2}{|c|}{$\begin{array}{l}\text { Health } \\
\text { Education Activity }\end{array}$} & \multirow{2}{*}{$\begin{array}{l}\text { F-values } \\
\text { Between } \\
\text { groups }\end{array}$} \\
\hline low & hlgh & \\
\hline 3.31 & 3.35 & .13 \\
\hline 3.29 & 3.37 & .82 \\
\hline 2.96 & 3.24 & $5.50^{*}$ \\
\hline 3.27 & 3.57 & $3.76^{\star}$ \\
\hline 2.84 & 3.15 & $6.47^{*}$ \\
\hline 2.74 & 3.02 & $5.95^{*}$ \\
\hline 3.40 & 3.27 & 2.11 \\
\hline 2.98 & 3.00 & 0.02 \\
\hline 3.06 & 3.23 & 2.18 \\
\hline 2.93 & 3.04 & 0.90 \\
\hline
\end{tabular}

Although all competencies are rated higher among those professionals reporting more health education activities, only planning, implementation "policy development and coordination show weakly significant differences. Current involvement in health education activities predisposes professionals' willingness to elaborate on these four competencies mentioned here above to a moderate extent. No ceiling effect seems to occur in the case of these competencies.

As a fourth step the data concerning the perception of health education in the desired situation are summarized by the sumscore (range 25 to 50 ) of the ten competencies, thus representing the overall extent to which professionals want to decrease or increase their attention for health education in their future professionall performance. Being asked whether they wanted to either increase or decrease their attention for distinguished health education competencies respondents indicated the extent to which this was the case, on a five-point scale. 
Table 6.10 Health education in the desired situation, factor analysis and reliability per group

Health Education Competency

1.Creating conditions

2.Assessment

3.Planning

4.Implementation

5.Policy development

6.Coordination

7.Developing relationships

8.Counseling and guidance

9.Evaluation

10.Research

Eigen value

Percentage of variance explained Cronbach's alpha

\begin{tabular}{|r|r|r|}
\hline \multicolumn{3}{|c|}{ Communallties } \\
\hline $\begin{array}{r}\text { Schooi } \\
\text { teachers }\end{array}$ & $\begin{array}{r}\text { Community } \\
\text { nurses }\end{array}$ & $\begin{array}{r}\text { General } \\
\text { practitioners }\end{array}$ \\
.63 & .62 & .38 \\
.51 & .63 & .40 \\
.74 & .66 & .66 \\
.36 & .48 & .49 \\
.80 & .62 & .63 \\
.81 & .59 & .65 \\
.62 & .54 & .61 \\
.49 & .41 & .49 \\
.62 & .56 & .64 \\
.73 & .30 & .43 \\
\hline 6.30 & 5.42 & 5.38 \\
63 & 54 & 54 \\
.93 & .90 & .90 \\
\hline
\end{tabular}

As was the case with health education in the actual situation, the perception of health education in the desired situation appeared to consist of one factor among all professional groups, with high reliabilities, Cronbach's alpha varying from .90 to .93.

The statistical characteristics of HEP.D are given in table 6.11.

Table 6.11 Health education perception in the desired situation; statistical characteristics of the sumscore (range 25 to 50)

\begin{tabular}{l|c|c|c|}
\hline \multirow{2}{*}{ Median } & Schoolteachers & $\begin{array}{c}\text { Community } \\
\text { nurses }\end{array}$ & $\begin{array}{c}\text { General } \\
\text { practitioners }\end{array}$ \\
\cline { 2 - 4 } Standard deviation & 33 & 33 & 30 \\
Skewness & 7.3 & 6.6 & 7.3 \\
Mean & -.74 & -.98 & -1.16 \\
\hline
\end{tabular}

School teachers and community nurses want to give more attention to health education in their work setting, though the differences between the former two groups and the latter being less than three points is not as clear as with regard to health education in the actual worksetting. 


\subsubsection{Health education in the actual and the desired situation combined; a typology of health education perceptions}

As was shown, the Health Education Competencies List covers a large number of health educationall aspects of the professionall performance of key health professionals. The internal consistencies of the ten main categories of competencies appeared to be high in all professional groups, Cronbach's alpha's ranking between .90 and .93 . On the basis of these results it was decided to calculate sumscores, characterizing health education in the actual and in the desired situation of the three professions. As a next step individual professionals were characterized with regard to their perception of health educational aspects of their work in the actual and the desired situation.

The perception of health education in the actual situation was dichotomized, HEP-A

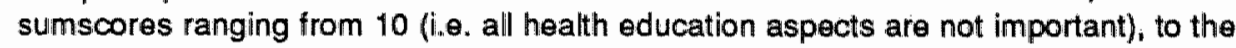
middle of the scale (empirical width $40-10=30 / 2=15$. mid $=15+10=25$ ), being coded as LO; HEP-A sumscores ranging from 26 to 40 being coded as HI. The perception of health education in the future situation was trichotomized, HEP-D sumscores ranging from 10 (i.e. all health educational aspects deserve less attention) to 28 (thus constituting a category containing the $33 \%$ lowest HEP-D sumscores), from 29 to 34 (a category containing the middle $33 \%$ ) and from 35 to 50 (containing the upper $33 \%$ of HEP-D sumscores). On the basis of this categorization a matrix is created "representing six types of health education perceptions, which were labelled as follows:

1. The health education abstentionist perceives health education as being relatively unimportant or not important at all in the actual professional performance and wishes to devote less attention to it.

2. The health education pessimist characterizes those professionals for whom health education is rather unimportant in the actual situation and who want to keep it that way.

3. The potential health educator perceives health education as being rather unimportant in the actual performance, but wishes to devote more attention to it.

4. The withdrawing health educator perceives health education as being rather important in the actual professional performance but wishes to devote less attention to it.

5. The health education optimist characterizes those professionals for whom health education is important in the actual professional performance and who want to keep it that way.

6. The activist health educator perceives health education as being rather important in the actual performance and who aspires to devote more attention to it. 
The following table gives an overview of the typology.

Table 6.12 Health education perception typology

\begin{tabular}{l|c|c|c|}
\hline $\begin{array}{l}\text { Health education In } \\
\text { actual situation } \\
\text { HEP-A scores }\end{array}$ & \multicolumn{3}{|c|}{ Health education In desired situation } \\
& LeP-D scores \\
\cline { 2 - 4 } & $10-28$ & Equal & More \\
& $N=74$ & $29-34$ & $35-50$ \\
$10-25$ Low & $N=123$ & $N=89$ \\
$N=178$ & Abstentionist & Pessimist & Potential \\
$26-40$ High & 63 & 83 & 32 \\
$N=108$ & Withdrawer & Optimist & Activist \\
\hline
\end{tabular}

In table 6.13 these categories and the typology is presented as well as the number of professionals falling into each category of the typology.

Table 6.13 Health education typology

\begin{tabular}{l|c|c|c|c|}
\hline \multirow{2}{*}{ Typology } & \multicolumn{4}{|c|}{ Professlonal groups } \\
\cline { 2 - 5 } & $\begin{array}{l}\text { School } \\
\text { teachers }\end{array}$ & $\begin{array}{l}\text { Community } \\
\text { nurses }\end{array}$ & $\begin{array}{l}\text { General } \\
\text { practitioners }\end{array}$ & $\begin{array}{l}\text { All profes- } \\
\text { sions }\end{array}$ \\
\cline { 2 - 5 } & 20 & 15 & 30 & 22 \\
Abstentionist & 5 & 5 & 2 & 4 \\
Withdrawer & 23 & 20 & 44 & 29 \\
Pessimist & 12 & 25 & 5 & 14 \\
Optimist & 6 & 13 & 14 & 11 \\
Potential & 34 & 22 & 5 & 20 \\
Activist & 95 & 98 & 94 & 287 \\
N & & & & \\
\hline
\end{tabular}

Among school teachers, most respondents appear to be activists for health education, though there is also a sizeable proportion of pessimists and abstentionists. Only few are withdrawing or potential health educators. Among community nurses the biggest proportion is the optimist group closely followed by the activists: abstentionists and pessimists are less frequent. Only few are withdrawers. General practitioners mostly are in the group of the pessimists and abstentionists: optimists and activists are rare among general practitioners. On the whole, there are considerable differences between the schoolteachers and the community nurses on the one hand and the general practitioners on the other. There appear to be considerably more activists among teachers than among the average key health professional. Among nurses there are more optimists, while among general practitioners pessimists and abstentionists are more prevalent. 
Although among general practitioners some more 'potential' health educators can be found, optimists and activists are much harder to find among them than among the key health professionals in toto.

\section{Collaboration}

Health education, most of the time, is not just a solo activity. Cooperation with other individuals, lay and professional as well as with other organizations is often necessary to create conditions for effectivity. Therefore, the level of collaboration with regard to health education is also considered to be a variable one needs to take into account in giving a picture of health education in the work of key health professionals.

With whom do key health professionals collaborate when carrying out health education? Respondents were asked to indicate whether they had had contact with other professionals or instances during the last year, in relation to health educational activities. In table 6.14 the percentages of the professionals having been in touch with those instances are presented per protessional group.

Table 6.14 Contacts with other instances concerning health educational activities

Instances

1. School physician

2. School nurse

3. Community nurse

4. School dentist

5. Oral hygienist

6. School service department

7. Hospital

8. School inspector (health)

9. Health service department

10. Orthodontologist

11. Social worker

12. Arts center

13. Mental health service

14. Community center

15. University

16. Patient association

17. Action group

18. General practitioners

\begin{tabular}{|rrr|}
$\begin{array}{r}\text { School } \\
\text { teachers }\end{array}$ & $\begin{array}{r}\text { Community } \\
\text { nurses }\end{array}$ & $\begin{array}{r}\text { General } \\
\text { practitioners }\end{array}$ \\
\hline 91 & 58 & 75 \\
52 & 45 & 17 \\
14 & - & 76 \\
80 & 6 & 13 \\
54 & 3 & 6 \\
77 & 21 & 43 \\
36 & 89 & 79 \\
67 & 29 & 30 \\
27 & 43 & 62 \\
11 & 3 & 9 \\
38 & 96 & 88 \\
23 & 17 & 10 \\
- & 67 & 79 \\
26 & 54 & 36 \\
22 & 15 & 62 \\
2 & 56 & 26 \\
8 & 31 & 25 \\
45 & 95 & - \\
\hline
\end{tabular}

* Cells contain percentages of those indicating collaboration.

The school system and the health care system have a certain overlap, not only in contacts with school physician, school nurse, school dentist, school service department and school health inspector, but also through the university, the hospital and the health service department. Of course, this does not imply any coordinated action, this only 
reveals the pattern of the network. It is striking that social workers, patient associations and action groups are so important to the community nurses' and general practitioners' health educational activities, while these latter two seem unknown in the school. Contacts with a social worker are not half as frequent among teachers as among community nurses and general practitioners. As a next step the number of contacts per individual professional was calculated, resulting in a sumscore, the trichotomized distribution of which is shown in table 6.15 , as well as the statistics.

Table 6.15 Contacts with other instances concerning health education

\begin{tabular}{l|c|c|c|c|}
\hline \multirow{2}{*}{$\begin{array}{l}\text { Number of contacted } \\
\text { Instances over the }\end{array}$} & \multicolumn{3}{|c|}{ Professional group (percentages) } \\
\cline { 2 - 5 } last year & $\begin{array}{l}\text { School } \\
\text { teachers }\end{array}$ & $\begin{array}{l}\text { Community } \\
\text { nurses }\end{array}$ & $\begin{array}{l}\text { General } \\
\text { pract. }\end{array}$ & $\begin{array}{l}\text { All } \\
\text { professionals }\end{array}$ \\
\cline { 2 - 5 } few (3-7) & 61 & 26 & 35 & 40 \\
average (8-11) & 30 & 50 & 37 & 40 \\
many (12-18) & 9 & 24 & 25 & 20 \\
median & 7.0 & 10.0 & 9.5 & 8 \\
standard deviation & 3.2 & 3.2 & 3.7 & 3.6 \\
skewness & .31 & -.12 & .06 & .10 \\
mean & 6.8 & 9.3 & 9.2 & 8.4 \\
\hline
\end{tabular}

On the whole general practitioners and community nurses have had more contacts concerning health education activities over the last year, than had elementary schoolteachers.

Relationships of health education perception with health education activities and collaboration for health education

The relationship between, on the one hand, health education perception in the actual and desired situation and on the other hand self-reported health education activities, collaboration with other professionals and organizations is studied by means of the correlational structure, and analysis of variance. In table 6.16 correlations are presented per professional group.

Table 6.16 Relationships between health education in the actual and desired situation, correlations with activities, collaboration

\begin{tabular}{|c|c|c|c|}
\hline $\begin{array}{l}\text { Pearson's } \\
\mathbf{R}\end{array}$ & $\begin{array}{l}\text { School teachers } \\
\text { Health education } \\
\text { Actwal Desired }\end{array}$ & $\begin{array}{l}\text { Community nurses } \\
\text { Health oducation } \\
\text { Actual Desired }\end{array}$ & $\begin{array}{l}\text { General practitioners } \\
\text { Health education } \\
\text { Actual Desired }\end{array}$ \\
\hline $\begin{array}{l}\text { Desired } \\
\text { Hoalth Educ. Activities } \\
\text { Collaboration }\end{array}$ & $\begin{array}{l}.64^{* *} \\
.01 \\
.17\end{array}$ & $\begin{array}{ll}.51^{* *} & \\
.19 & .03 \\
.22 & -.04\end{array}$ & $\begin{array}{l}.26^{* * *} \\
27^{*} \\
34^{* *}\end{array}$ \\
\hline
\end{tabular}


The relationship between health education as it is perceived in the actual work setting and as professionals would like to see it in the near future is quite strong among teachers and nurses, less strong but still highly significant among general practitioners. Strangely enough, the relationship of correlations with concrete theme centered variables on aspects of their health education activities is absent or weak among schoolteachers and community nurses. Among general practitioners this relationship is clearly present with regard to health education in the actual situation.

\subsection{Discussion}

In this section the method used to measure health education perception is discussed; the results are compared to results of previous research on the subject.

\subsubsection{Method}

This chapter reports on an attempt to measure health education perception in the work setting. No validated and reliable instruments were available. The categories developed for curriculum planning for health education, that have been used here, have allowed the construction of health education perception sumscores with high Cronbach's alpha's. Our attempt to validate this variable by means of questions on concrete health education activities were only partly successful in as far as schoolteachers and community nurses are concerned.

On the one hand when HEP-A scores per competency were dichotomized by the level of health education activities, these appeared to be higher for those reporting a high level of health education activities and low for those who did not. On the other hand, the relationship of HEP.A with health education activity level could not be demonstrated among schoolteachers and community nurses once a scale was assumed to exist summarizing all health education aspects of key health professionals' work. Only among general practitioners this relationship was significant. Upon the positive assessment one would be inclined to make, of the health education perception among these two professions, big doubts were cast by the apparent lack of coherence among what these professionals say they are doing with regard to health education in their work setting. Even the positive relationship found among general practitioners probably is nothing but the consistency of the abstentionist view on health education, so prevalent among the general practitioners.

The health education typology provided a useful categorization to be used in further analysis of relationships with health behavior and exemplary role recognition.

\subsubsection{Comparison with prevlous research}

As yet no research applying identical instruments is available. The health education competencies list was used in Belgium among Flemish general practitioners recently. In the next section related research is discussed to improve our understanding of the results reported in the preceding paragraphs. 


\section{* Schoolteachers}

Expectations towards the school system as health education change agent have been seen growing over the last decades (Draijer, 1985; Kolbe \& Iverson, 1980). Roadblocks to an effective health education implementation were mentioned frequently with regard to teaching as well as to general practice (Van den Akker \& Visser, 1984; Campbell \& Valente, 1983; Karenko, 1984; Panis \& Veerman, 1985). Integration of health education at all levels (Hegger, 1980) certainly is desirable. However, at this moment simple coordination of health education is lacking. It has to be established while views on health education diverge greatly. From our results it can be seen that schoolteachers perceive health education as quite important, both in the actual and the desired situation. The lack of relationship with health education activities indicates that a positive attitude towards health education does not necessarily mean it gets more attention in the classroom. This was found by Van den Akker \& Visser (1984) in Amsterdam too. It should be kept in mind that this survey was held before health education was introduced as an official subject in the elementary school by the Law of 1985 . The majority $(52 \%)$ of the teachers being either optimist, potential or activists in terms of our typology (table 6.11, fig. 6.1), this situation can be considered as a challenge to school health education planners: there is a large part of fertile soil for health education in the Dutch elementary schools. A legal framework is actually present to support this school health education planning and implementation.

High expectations with regard to community nurses' and general practitioners' health education potential, stressing their unique position of trust with the patient, were explicited regularly. Empirical data showed a modest involvement (De Maeseneer \& Maes, 1982), and scarce evidence with regard to effectivity (Calnan \& Johnson, 1983).

\section{* Community nurses}

Our results show that community nurses perceive health education as important in their work now, and in the future. The weak relationship found between the perception of health education in the actual situation and the level of health education activity, indicates that community nurses know health education is important, but only partially have the opportunity and/or ability to practice it. As was shown earlier the balance between prevention and cure in the professional activities seems to shift back continually towards the curative end of the spectrum. Health education training within the National Cross Health Care Organization, employer of most community nurses in the country, has been exemplary in many aspects, certainly was the first to be developed. This circumstance no doubt contributed to the situation that $60 \%$ of the community nurses were either optimist, potential or activists, i.e. on the positive side of the health education typology (table 6.12). Community nurses have much more practical experience with health education than most teachers have. Nevertheless a clear framework to support their health education activities in relation to prolessional health educators' activities is still lacking. In health care planning and especially in budgets the government has shown unbalanced attention for health education (Hagendoorn, 1986). Only recently health care policy development was structurally underpinned by a health promotion viewpoint (Ministerie van WVC, 1986). As the Health 2000 strategy eventually gets translated into budgets and full time equivalents this will improve the organizational framework for health education delivery by community nurses. 


\section{* General practitioners}

General practitioners perceived health education as clearly less important in their work than did schoolteachers and community nurses. General practitioners could be more sceptical about health education: as was found by Ford \& Ford (1983), only a small minority was in favour of health education. Our survey showed $24 \%$ of the general practitioners was either optimist, potential or activist health educator. Given the scepticism found by Ford \& Ford, and the discouragingly low results reported by Boots (1983) and Van Zutphen (1984) concerning time-spending, the finding that one quarter of the general practitioners might be genuinely interested in health education delivery is probably realistic. Of course, general practitioners' space is different from schoolteachers' or community nurses' role space for health education. As thealth education can be carried out in primary, secondary and/or tertiary prevention efforts, and as none of these were singled out comparablity of role performance concerning health education has been maintailned, although accents among schoolteachers are on primary prevention, among community nurses on all three levels, and among general practitioners on secondary and tertiary levels mainly (De Maeseneer \& Maes, 1982).

\subsection{Conclusions}

1. The list of health education competencies is a statistically and contentwise satisfactory instrument to measure the perception of health educational aspects in the work of key health professionals.

2. Nurses attach greatest value to planning, implementation and the development of relationships for health education. By teachers, policy development, implementation and creating conditions for the development of health education are perceived as the most important competencies. By general practitioners, implementation is perceived as by far the most important, followed by creating conditions and assessment. None of the three professional groups perceives coordination as an important aspect of current professional performance. Coordination is the lowest scoring compettency among community nurses and general practitioners, the all but one lowest among schoolteachers. When asked about the attention given to the health education competencies in the desired situation, none of the prolessional groups aspires to fultil a coordination function.

3. On the whole, schoolteachers and community nurses perceive health education in their actual work as more important than do general practitioners. Desired change in attention for health education competencies in the future is only partially significantly different between the professional groups of whom schoolteachers and community nurses want to give more attention especially to planning and implementation.

4. Schoolteachers and community nurses in the Netherlands have high aspirations concerning their level of health education activities. These do only partially relate to their current level of health education activities.

5. General practitioners are less ambitious than schoolteachers and community nurses in the field of health education. A considerable number seem not to want to be involved at all, not now and not in the future, while the public has high expectations of general 
practitioners as most credible information sources about health, and notwithstanding the fact that the medical profession regularly brings straightforward claims for parts of health education delivery, pointing at organizational and financial roadblocks frustrating their beneficial realization.

\subsection{Summary}

In this chapter the perception of the health educational aspects of the tasks of schoolteachers, community nurses and general practitioners in their actual work and in the desired situation are dealt with. The development of the health education competencies list at the University of Limburg is described. In the actual situation, schooiteachers and community nurses do perceive health education as being more important than do general practitioners. None of the three professional groups aspires at fulfiling the coordination function for health education. Those key health professionals who practise more health education activities, do perceive health education as more Important. In the future, school teachers and community nurses want to increase their attention for health education, general practitioners marginally. Both HEA and HED variables appear to constitute scales with high reliabilities. A typology is presented distinguishing six types of health education perception. General practitioners and community nurses collaborate more with other instances for health education objectives than do schoolteachers. Health education perception in the actual and desired situation are positively related. The number of health education activities is positively related to the perceived importance of health education in the actual worksetting for general practitioners, weakly so for community nurses and unrelated for schoolteachers. It is concluded that the health education competencies list is a useful instrument to measure health education perceptions of key health professionals. Prioritized and neglected education competencies are mentioned per professional group. Among all three groups, there are reasons to further develop health education.

Literature references: see chapter 2. 


\section{Appendix A}

Table 6.17: Health education activities

Type of activity

1. Dissemination of leaflets

2. Dissemination of a patient diary

3. Start or maintain a patient library

4. Arrange waiting room as an educational tool

5. Organize health education sessions

6. Contraceptive education

7. Pregnancy education

8. Childrens' growth and development programs

9. Contribution to external health education events concerning specific health problems

10. Health market

11. Stimulate patient participation

12. Explain drug information leaflets

13. Explain possible drug interaction effects

14. Stimulate the use of a drug check- list

\section{Appendix B}

Table 6.18: Health education activities

\section{Type of activity}

Carried out by teachers (\%)

1. Regulate type of snacks children are bringing with them to school

2. Take away poisonous plants from the classroom

3. Make sure that birthday treats are sugerfree

4. Make arrangements with parents on safe travel to and from school 40

5. Not permit childrens' smoking in or outside the school

6. Arrangements for teeth brushing at school

7. School's exit is safe-guarded from children running out on the street 38

8. There is a regular fire safety check

9. There is a regular safety check on electrical appliances

10. There is at least one person who is able to provide first aid 66

11. A first aid kit is regularly checked

12. Teachers do not smoke in the classroom

13. Safety guards help the children crossing the streets before and after school hours

14. At school children receive fluoride tablets 
122

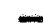




\title{
Chapter 7.
}

\section{Health behavior: results}

\author{
by Hans Adriaanse and Tjaard Imbos* \\ "Department of Statistics and Medical Information, \\ University of Limburg
}

7.1 Introduction

7.2 Operationalization of health behavior

7.3.1 Health behavior of the professional groups

7.3.1.1 Breakfasting

7.3.1. 2 Coffee consumption

7.3.1. 3 Tooth brushing

7.3.1. 4 Dental check-up

7.3.1.5 Snacking sweets

7.3.1. 6 Sugar consumption

7.3.1. 7 Smoking

7.3.1. 8 Alcohol

7.3.1. 9 Sleep

7.3.1.10 Maintenance of proper weight

7.3.1.11 Washing hands

7.3.1.12 Safety belt use

7.3.2 Comparison between the professionals' health behavior and the population

7.3.3 Health behavior index

7.4 Discussion

7.4.1 Remarks

7.4.2 Professionals - population at large

7.4.3 Comparison with earlier research

7.4.3.1 Schoolteachers

7.4.3.2 Community nurses

7.4.3.3 General practitioners

7.5

Conclusions

7.6 Summary 


\subsection{Introduction}

In this chapter the second of the central questions formulated at the end of chapter 1 will be addressed: "What is the nature of key health professionals" health behavior in light of current health norms?" Do key health professionals behave differently than the general population? Health behavior is a culturally determined concept which varies over time. As was shown in paragraph 3.2, health behavior can be thought of as a group of behaviors related to health in an unsystematic way. People intendedly carry out activities to foster their health, e.g. breakfast regularly, eat moderately or practice jogging, or purposely retrain from others, e.g. smoking or immoderate alcohol consumption, being only partially consistent in these health-related behaviors. This atomistlc approach was discussed in paragraph 3.2.1. Others argued that a number of behaviors have found to be related to morbidity and mortality. From this they concluded that these behaviors were related to positive health in a cumulative sense. Therefore, health behavior is considered as a set of behavioral items the sum of which represents the extent to which an individual behaves in a healthy way. Prolonged longevity due to adherence to four or five HPL-practices for males was estimated to be 11 years for males and 7 years for females (Belloc, 1972). This additivity approach to health behavior leading to the creation of a health behavior index (HBI) which was discussed in paragraph 3.2.2. A third approach to health behavior is the scaling approach. The delineation of health behavior is empirically based on responses of populations. Internal consistencies between items determine the inclusion of behaviors into the health behavior scale (HBS). The scallng approach was discussed in paragraph 3.2.3.

As was explained in chapter 3 , a universally accepted way of measuring health behavior does not exist. As was mentioned, the choice for the line of reasoning underlying the additivity approach of the Human Population Laboratory from Berkeley was considered the most convincing. The argument runs as follows:

1. Individual health status is influenced by personal health behavior (PHB).

2. A number of PHBs are involved with increased risk for disease and/or for premature death.

3. Key health professionals are aware of these potential risks.

4. Berkman and Breslow substantiated a strong relationship between the health practices in their $\mathrm{HBl}$ and mortality risk (Berkman \& Breslow, 1983, chapter 3).

5. This study focuses on the relationship between health and behavior, not just on subjective health conceptions which might exclude for instance smoking (Kristiansen \& Harding. 1984). The strong relationship of smoking to morbidity and mortality renders inclusion in the HBI mandatory. Smoking, the Body Mass Index, alcohol consumption, exercise and sleeping hours were related independently to mortality: this was not true for eating breakfast and snacking.

As will be explained, the additivity approach was modified contentwise: health practices were added. Moreover, the disadvantages of the HBll were minimized by the posthoc application of the Rasch-scaling approach: thereby, this HBI version could be better underpinned from the empirical viewpoint. 
The HBI-items were selected from 19 questions pertaining to health-related behavior, which were assumed to be health-directed also in the case of the key health professionals, given their training and experience in the health field. Seven of these 19 items were not used in the analysis for the following reasons. Questions concerning the use of (soft-or hard-)drugs, the use of fluoride tablets, washing hands after sanitary stops, ignoring red traffic lights driving a bicycle or a car, yielded very skewed distributions. Almost all respondents answered these questions negatively. As these items would differentiate insufficiently they were deleted. Two other items, though concerning health behaviors in their wording asked for a personal assessment of satisfaction with, rather than for a self report on health behavior; therefore questions on relaxation and on assessment of point in time of going to bed had to be deleted. Thus, twelve health behaviors remained. The results are presented in the next section per health behavior, by professional group (7.3.1.1 - 7.3.1.12). Then a comparison with the health behaviors of the population at large in the Netherlands is made, followed by an analysis of the relationship between the health behaviors, as measured in key health professionals (7.3.2). As a fourth step, the Health Behavior data are tested whether they meet the requirements of the Rasch-model. After passing this test the HB-Index is upgraded to a HB-Scale (HBS). Its distribution and statistical characteristics are presented in 7.3.3.

\subsection{The operationalization of health behavior}

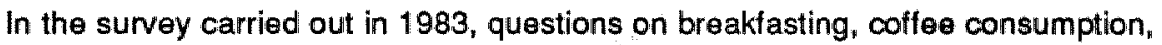
hygiene, preventive dental care " safety, nutrition, resting and sleeping habits, weight by height, tobacco and alcohol consumption were used to measure health behavior.

The Quetelet-index is no health behavior itself but is a result of exercise, nutritional behavior and constitution. The HBS was constructed as follows: norms were set to each health behavior in such a way that the variable could be dichotomized. Thus, for each of the twelve items each respondent could obtain either one or zero points. The HBS thus ranges between zero and twelve points, a score of zero representing very unhealthy, a score of 6 and over representing a (rather) healthy behavior. The norms set to each item were the following. It should be mentioned at the outset - though socially accepted as health norms - the conclusiveness of the underlying evidence is differing among the diverse health practices.

\section{Breakfasting}

Asked whether one was breakfasting in the morning, respondents could indicate its frequency, i.e. breakfasting always, regularly, mostly not or never. Breakfasting every day or regularly was considered to be healthy on the basis of the relationship to mortality (Fabry \& Temperman, 1970; Belloc \& Breslow, 1972; Belloc, 1973; Berkman, Breslow \& Wingard, 1983) found an association of infrequent meal pattern with mortality from IHD). There was no evidence for an independent association of breakfast with mortality, as was stated more precisely by Berkman \& Breslow (1983). 


\section{Coffee}

Asked how many cups of colfee one consumes on the average per day, the respondent could indicate the frequency of coffee drinking habit: 0 till 9 and over. A number of 5 cups of coffee inclusive was considered to be not unhealthy, while 6 and more cups was considered to be unhealthy (Smits, 1986). Although it is widely accepted that immoderate cotfee consumption is unhealthy due to the caffeine in tt, both the relationship of coffee intake with morbidity and mortality as well as the relationship of caffeine with specific disease-causing factors have not been clearly established (Heyden, Tyroler, Heiss, et al., 1978; Murray, Bjelke, Gibson \& Schuman, 1981; Heyden, Schneider, Ruh \& Fodor "1986; Smits, 1986). For instance in the Framingham study a relationship of coffee consumption with death from all causes was found, but no specific relation to coronary heart diseases, angina pectoris or myocardial infarction (Dawber, Kannol \& Gordon, 1974).

A revlew of 21 studies on coffee consumption and cholesterol levels shows that sometimes strong correlations are found, sometimes none (Heyden, Schneider, Ruh \& Fodor, 1986). On the basis of a review of nearly 300 studies on the health consequences of caffeine; it is concluded that no relationship exists between coffee consumption and myocardial infarction, while the research into the role of caffeine with regard to other diseases is still inconclusive but "further research into the health consequences of the most widely consumed drug in Western society is clearly needed" (Curatolo \& Robertson, 1983).

\section{Toothbrushing}

Asked how often one used to brush the teeth a day, the respondent could indicate whether this was usually done one, two, three times a day or more, less than once a day or not at all. A frequency of two or three times a day is considered to be healthy (Eykman \& Visser, 1987).

\section{Dental check-up}

Asked whether one used to go to the dentist for a preventive check-up, the respondent could indicate whether these visits were made every six months, once a year, less often or never " A bi-annual check-up trequency was considered to be healthy (Van Groenestijn, Maas- De Waal, Swallow \& Mileman, 1979). Some association between regularity of dental and general medical check-up and mortality has been found by Berkman, Breslow and Wingard, 1983. While the effectiveness of the biannual dental checkup has been defended for many years, it is argumented against also (Schruurs, 1986).

\section{Snacking sweets in between meals}

The respondent could indicate the frequency of snacking sweets: always, mostly, mostly no sweets or never any sweet snacks. The latter two alternatives were considered to be healthy. Snacking in between meals is related to mortality but not strongly and the pattern is inconsistent. Regularity of meals seems to be the most important aspect (Berkman, Breslow \& Wingard, 1983). 
The use of sugar in coffee Asked whether one drank coffee with sugar, the respondent could indicate the frequecy of the habit. The choice for hardly or never was considered to be healthy, in view of the potential damage done to the teeth by the use of sugar additives (Eykman \& Visser, 1987).

\section{Smoking}

Asked whether one smokes or not, respondents could indicate their smoking status being current, former or never smoker. The consumption of one cigarette, manufactured or handrolled, one cigar or pipeful of tobacco per day, was considered to be unhealthy. The relationship of smoking to morbidity and mortality is the strongest one of all health behaviors. It has been established in many investigations, e.g. Doll \& Hill ${ }^{1964 ;}$ Hammond, 1966; USDHEW, 1967-1986; Kannel, 1971; Royal College of Physicians, 1972; Berkman, Breslow \& Wingard, 1983; Van Arkel \& Sturmans, 1985).

\section{Alcohol consumption}

Asked how often one used to drink six glasses or more of alcoholic beverages over the last year, the respondent could indicate whether this was the case at all, and, if so, how frequently, ranging from once a year till every day. The consumption of less than six glasses was considered to be healthy. This level of "sate" alcohol consumption is on the high side. Only $25 \%$ of alcohol research experts considered six or more glasses to be the upper safe limit (Anderson, Cremona \& Wallace, 1984). The relationship of alcohol to health is a U-shaped distribution, meaning that both no alcohol and immoderate alcohol consumption are associated with ill health, while moderate consumption is associated with a healthy state. The lower safe limit, obviously difficult to adhere to, is two drinks per day (Kannel, 1977; Castelli, 1979). The relationship of immoderate alcohol consumption with mortality from all causes has been established in many investigations, e.g. Room \& Day, 1974; Hennekens, Willett; Rosner, Cole \& Mayrent, 1979; Marmot, Rose, Shipley \& Thomas, 1981). It is argued that moderate alcohol consumption reduces the risk on coronary heart diseases (Knipschild, 1984), but higher risk of dying from stroke accidents or violence (Kozararevic, McGee, Vojvodic et al., 1980). Knibbe arguing against Knipschild posits that low alcohol consumption does not cause ill health, but that many persons in relative bad health either decide themselves not to drink alcohol-containing beverages are advised by their physician not to do so (Knibbe, 1984). Sometimes a specific beverage is identified as having a CHD-protective effect ( $\theta . g$. beer by La Porte, Cresanta \& Kuller, 1980).

In a study on the alcohol consumption and 17-year mortality in American middle aged white males $(\mathbb{N}=1832)$, increased death risk was found at the level of six drinks per day or more. There was no increase with increasing alcohol consumption below that level (Dyer, Stamler \& Oglesby, 1980).

\section{Sleep}

Asked at what time one usually goes to bed in the evening and at what time one gets up in the morning, respondents indicated the number of hours they used to sleep. A number of sleeping hours between 7 and 8.75 is considered to be healthy, while fewer or more sleeping hours are not. A relationship with mortality was found by Hartmann, Baekeland, 
Zwilling \& Hoy, 1971; Belloc \& Breslow, 1972; Belloc, 1973; Oswald, 1976; Kripke, Simons, Gartinkel \& Hammond, 1979; Berkman, Breslow \& Wingard, 1983.

\section{Maintaining proper weight}

The maintenance of proper weight has been measured with the Quetelet-index. Respondents were asked about one's height in meters and one's weight in kilograms. The Body Mass Index or Quetelet Index could be calculated by dividing weight by squared length. Quetelet-indexes of 25.9 or under for females and equal to 26.9 or under for males, were considered to be healthy (Kok, Matroos \& Vandenbroucke, 1981). A relationship of QI with mortality was found by Kannel, LeBaver, Dawber \& McNamara, 1967; Keys, Aravanis \& Blakburn, 1972; Levinson, 1977; Bray, 1981).

\section{Washing hands}

Asked about manual hygiene respondents could indicate whether they washed their hands always, frequently, sometimes or never before having a meal. No recent research evidence is presented nor needed, since Semmelweis proved the contribution of this health practice to health status. Washing hands always or frequently is considered to be healthy, not practising this to be unhealthy.

\section{Seatbelt use}

Asked about the use of safety beits while driving a car, respondents could indicate whether they always or usually did so, or not. Frequent use of seatbelts was considered to be healthy, whereas infrequent use was not. Although the use of seatbelts is mandatory in the Netherlands, the evidence is inconclusive. The use of seatbelts reduces injuries by $65 \%$, fatalities by $50 \%$ (Nichols, 1982; Sleet, 1984). According to Adams who analyzed effects of mandatory seatbelt use internationally, no favorable effect on traffic safety could be shown (Adams, 1985). For the Netherlands specifically, the index of road accidents deaths $(1973=100)$ on its way down until 1975, went up from 78 (1975) to 85 in 1977 . Only in 1978 a lower level of traffic mortality was attained than before mandatory seatbelt use was introduced (Janssen, 1987).

\subsection{Health behaviors of the professional groups}

\subsection{1}

In this section the 12 health behaviors as reported by the three professional groups are presented: distribution, differences between groups, means, relation to age and gender if applicable. 


\subsubsection{Breakfasting}

The first health behavior professionals were asked' to report about was the regularity of their breakfasting.

Table 7.1: Breakfasting

\begin{tabular}{l|c|c|c|c|}
\hline $\begin{array}{l}\text { Are you having breakfast } \\
\text { In the morning? }\end{array}$ & $\begin{array}{c}\text { school- } \\
\text { teachers } \\
\mathrm{N}=98\end{array}$ & $\begin{array}{c}\text { community } \\
\text { nurses } \\
\mathrm{N}=100\end{array}$ & $\begin{array}{c}\text { general } \\
\text { practitioners } \\
\mathrm{N}=100\end{array}$ & all \\
\cline { 2 - 5 } always & 76 & 86 & 80 & 81 \\
mostly & 9 & 9 & 7 & 8 \\
sometimes & 10 & 3 & 5 & 6 \\
never & 4 & 2 & 8 & 5 \\
mean & 3.6 & 3.8 & 3.6 & 3.7 \\
\hline
\end{tabular}

As can be seen in table 7.1 , nearly $90 \%$ of the key health professionals regularly takes breaklast in the morning. No significant differences appear between the groups $\left(F_{=1}, 13\right)$. Regularity of breakfasting increases with age $\left(r=11^{*}\right)$.

\subsubsection{Coffee consumption}

The second health behavior professionals were asked to report about was their coffee consumption.

Table 7.2: Coffee consumption

\begin{tabular}{l|c|c|c|c|}
\hline $\begin{array}{l}\text { How many cups of coffee } \\
\text { do you drink on the } \\
\text { average per day? }\end{array}$ & $\begin{array}{c}\text { school- } \\
\text { teachers }\end{array}$ & $\begin{array}{c}\text { community } \\
\text { nurses }\end{array}$ & $\begin{array}{c}\text { general } \\
\text { practitioners }\end{array}$ & all \\
Number of cups & $\mathrm{N}=98$ & $\mathrm{~N}=99$ & $\mathrm{~N}=100$ & $\mathrm{~N}=297$ \\
\cline { 2 - 5 } $0-2$ & 13 & 15 & 18 & \\
$3-5$ & 66 & 47 & 51 & 54 \\
$6-8$ & 18 & 31 & 27 & 27 \\
9 and over & 2 & 7 & 4 & 13 \\
\hline mean & 2.1 & 2.3 & 2.2 & 2.2 \\
\hline
\end{tabular}

As can be seen in table 7.2, the majorities of all three professional groups say they use less than 6 cups of coffee per day. Although community nurses on the average drink slightly more cups of coffee per day than teachers and general practitioners, these differences are not impressive $\left(F=3.03^{*}\right)$. Conservative calculation of the number of cups of coffee, using classmids and 10 as a maximum for the 9 and over category, shows that the average number of cups of coffee is 4.8 . 


\subsubsection{Tooth brushing}

The third health behavior key health professionals were asked to report about was dental hygiene.

Table 7.3: Tooth brushing

\begin{tabular}{l|c|c|c|c|}
\hline $\begin{array}{l}\text { How often do you brush } \\
\text { your teeth per day? }\end{array}$ & $\begin{array}{c}\text { school- } \\
\text { teachers } \\
\mathrm{N}-98\end{array}$ & $\begin{array}{c}\text { community } \\
\text { nurses } \\
\mathrm{N}=100\end{array}$ & $\begin{array}{c}\text { general } \\
\text { practitioners } \\
\mathrm{N}=100\end{array}$ & all \\
\cline { 2 - 5 } never & 0 & 0 & 0 & 0 \\
less than once & 1 & 1 & 1 & 1 \\
once & 21 & 15 & 19 & 19 \\
twice & 43 & 49 & 57 & 50 \\
three times or more & 33 & 35 & 23 & 30 \\
\hline mean & 4.1 & 4.2 & 4.0 & 4.1 \\
\hline
\end{tabular}

As can be seen in table 7.3 over three quarters of the professionals brush their teeth at least two or three times per day. Groups do not differ in this respect $(F=0.6)$. Frequency of brushing teeth diminishes with age $\left(r=-.13^{\prime \prime}\right)$.

\subsubsection{Dental check-up}

The fourth health behavior professionals were asked to report about was the frequency of their visits to the dentist for a check-up in a asymptomatic stage.

Table 7.4: Dental checkup

\begin{tabular}{l|c|c|c|c|}
\hline $\begin{array}{l}\text { Are you going for a } \\
\text { dental checkup? }\end{array}$ & $\begin{array}{c}\text { school- } \\
\text { teachers } \\
\mathrm{N}-98\end{array}$ & $\begin{array}{c}\text { community } \\
\text { nurses } \\
\mathrm{N}=100\end{array}$ & $\begin{array}{c}\text { general } \\
\text { practitioners } \\
\mathrm{N}=100\end{array}$ & all \\
\cline { 2 - 5 } never & 6 & 6 & 5 & 6 \\
less than once a year & 5 & 1 & 7 & 4 \\
once a year & 7 & 6 & 24 & 12 \\
twice a year & 82 & 87 & 64 & 78 \\
\hline mean & 3.6 & 3.7 & 3.5 & 3.6 \\
\hline
\end{tabular}

As can be seen in table 7.4 the great majority of the professionals goes for a dental check-up twice a year. No significant differences between groups appear to exist $(F=0.2)$. Frequency of asymptomatic dental visits declines with age $\left(r=-17^{* *}\right)$. 


\subsubsection{Snacking sweets}

The fitth health behavior key health professionals were asked about was how often they consumed sweets in between meals.

Table 7.5: Snacking

\begin{tabular}{l|c|c|c|c|}
\hline $\begin{array}{l}\text { If you consume anything } \\
\text { in between meals, } \\
\text { does thls concern sweets? }\end{array}$ & $\begin{array}{c}\text { school- } \\
\text { teachers }\end{array}$ & $\begin{array}{c}\text { community } \\
\text { nurses }\end{array}$ & $\begin{array}{c}\text { general } \\
\text { practitioners }\end{array}$ & all \\
\cline { 2 - 5 } never & 19 & $N=98$ & $\mathbf{N}=98$ & $\mathbf{N}=294$ \\
hardly ever & 36 & 43 & 20 & 19 \\
mastly & 40 & 35 & 41 & 41 \\
always & 3 & 1 & 36 & 38 \\
mean & 2.3 & 2.2 & 2.2 & 2 \\
\hline
\end{tabular}

As can be seen in table 7.5, about two fifths of the professionals mostly or always consume sweet snacks in between meals: the majority mostly uses other types of snacks or none. No significant differences are found between the professional groups $(F=0.2)$.

\subsubsection{Sugar consumption}

The sixth health behavior key health professionals were asked to report about was the use of sugar in their coffee.

Table 7.6. Sugar consumption

\begin{tabular}{l|r|r|r|r|}
\hline $\begin{array}{l}\text { Are you using suglar } \\
\text { in your coffee? }\end{array}$ & $\begin{array}{r}\text { school- } \\
\text { teachers } \\
N=98\end{array}$ & $\begin{array}{r}\text { community } \\
\text { nurses } \\
\mathrm{N}=97\end{array}$ & $\begin{array}{r}\text { general } \\
\text { practitioners }\end{array}$ & all \\
never & 33 & 69 & 42 & $\mathbf{N = 2 9 4}$ \\
sometimes & 3 & 6 & 7 & 49 \\
often & 4 & 2 & 1 & 5 \\
always & 57 & 23 & 50 & 2 \\
mean & 2.9 & 1.8 & 2.6 & 44 \\
\hline
\end{tabular}

As can be seen in table 7.6 sugar consumption is nearly a dichotomous variable. The large majority of the professionals either never or always use sugar. Less community nurses than schoolteachers and general practitioners appear to use sugar in their coffee: nearly $70 \%$ never uses it $\left(F=3.8^{*}\right)$. 


\subsubsection{Smoking}

The seventh health behavior key health professionalls were asked to report about was whether they used to smoke currently, formerly or never had smaked.

Table 7.7: Smoking

\begin{tabular}{l|c|c|c|c|}
\hline $\begin{array}{l}\text { Are you a current smoker } \\
\text { or not? Dld you ever smoke? }\end{array}$ & $\begin{array}{c}\text { school- } \\
\text { teachers } \\
\mathrm{N}-96\end{array}$ & $\begin{array}{c}\text { community } \\
\text { nurses } \\
\mathrm{N}=100\end{array}$ & $\begin{array}{c}\text { general } \\
\text { practitioners } \\
\mathrm{N}-98\end{array}$ & all \\
\cline { 2 - 5 } never smoked & 25 & 37 & 12 & 25 \\
former smoker & 39 & 32 & 32 & 34 \\
current smoker & 36 & 31 & 56 & 41 \\
\hline
\end{tabular}

The (non)-smaking habit is differently distributed in the professional groups $\left(X^{2}=14.65^{* * *}\right)$. As can be seen in table 7.7, those who never smoked tobacco are found mostly among community nurses, less among schoolteachers and hardly among general practitioners. About one third of the key health professionals has been a smoker but stopped using cigarettes, pipes and/or cigars. Among schoolteachers and community nurses, about one third is current smoker in 1983 , while over haff $(56 \%)$ of the general practitioners still smoked then. Although the smoking prevalence diminished within higher age groups (20-35: 44\%; 36-50: 41\%; 51-65: 36\%), these differences are not significant $\left(X^{2}-4.6 ; p=0.10\right)$.

\subsubsection{Drinking}

The eighth health behaviors key health professionals were asked to report about was their alcohol consumption in terms of frequency of drinking six or more glasses of alcohol containing beverage per day.

\section{Table 7.8: Alcohol consumption}

\begin{tabular}{l|c|c|c|c|}
\hline $\begin{array}{l}\text { How often did you drink } \\
\text { s|x glasses of alcoholic } \\
\text { beverages or more during } \\
\text { the last year? }\end{array}$ & $\begin{array}{c}\text { school- } \\
\text { teachers }\end{array}$ & $\begin{array}{c}\text { community } \\
\text { nurses }\end{array}$ & $\begin{array}{c}\text { general } \\
\text { practitioners }\end{array}$ & all \\
\cline { 2 - 5 } never & 4689 & $\mathrm{~N}=89$ & $\mathrm{~N}=97$ & $\mathrm{~N}=275$ \\
\cline { 2 - 5 } less than once per half year & 6 & 60 & 36 & 46 \\
once or twice per half year & 13 & 8 & 10 & 8 \\
three to five times per half year & 12 & 13 & 24 & 16 \\
once to thrice per month & 11 & 4 & 9 & 8 \\
once to thrice per week & 7 & 4 & 19 & 12 \\
tour to six times per week & 2 & 2 & 9 & 7 \\
every day & 0 & 0 & 0 & 2 \\
dont know/cannot say & 2 & 1 & 2 & 0 \\
\hline
\end{tabular}


As can be seen in table 7.8, immoderate drinking is uncommon among $60 \%$ of the community nurses. Among schoolteachers $54 \%$, among general practitioners $64 \%$ ever drinks six glasses or more per day. For most of them this accurs less than once a week.

\subsubsection{Sleep}

The ninth health behavior key health professionals were asked to report about was the length of their sleep, in terms of hours of sleeping between going to bed in the evening and getting up in the morning.

Table 7.9: Sleep

\begin{tabular}{l|c|c|c|c|}
\hline $\begin{array}{l}\text { Length of sleeplng } \\
\text { (hours) }\end{array}$ & $\begin{array}{c}\text { school- } \\
\text { teachers } \\
N=98\end{array}$ & $\begin{array}{c}\text { community } \\
\text { nurses } \\
N=100\end{array}$ & $\begin{array}{c}\text { general } \\
\text { practitioners } \\
N=100\end{array}$ & all \\
\cline { 2 - 5 } & 3 & 2 & 17 & 7 \\
less than 7.0 hours & 84 & 80 & 79 & 81 \\
between 7.0 and 8.75 hours & 13 & 18 & 4 & 12 \\
more than 8.75 hours & 8.0 & 9.0 & 7.4 & 8.2 \\
\hline mean & &
\end{tabular}

Sleeping can take from 4 hours till nearly 10 , as can be seen in table 7.9 , where duration of sleep is shown in three categories, those sleeping enough, i.e. between 7 and 8.75 hours and those sleeping less or more. Four fifths of the key health professionals do sleep sufficiently. However, no significant differences exist between professional groups $(F=0.4)$. Approximately one sixth of general practitioners sleeps less than 7 hours, while a comparable proportion of school teachers and community nurses sleeps longer than 8.75 hours. Length of sleep appears to increase with age $\left(r=13^{*}\right)$.

\subsubsection{Maintenance of proper weight}

The tenth health behavior key health professionals were asked to report about was their weight in kilograms and their length in meters. The so-called Quetelet Index, calculated by dividing length through squared weight is a health indicator related with health behaviors especially exercise and nutrition. In table 7.10 the results are presented, cells containing Ql-values categorized into underweight, normal weight, overweight and obese.

Table 7. 10: Quetelet Index

\begin{tabular}{|c|c|c|c|c|c|c|}
\hline Length by weight & $\begin{array}{l}\text { Oll: } \\
\text { male }\end{array}$ & female & $\begin{array}{l}\text { school- } \\
\text { teach. } \\
\mathrm{N}=98\end{array}$ & $\begin{array}{c}\text { comm. } \\
\text { nurses } \\
N=99\end{array}$ & $\begin{array}{l}\text { general } \\
\text { pract. } \\
N_{2 m} 99\end{array}$ & $\begin{array}{c}\text { all } \\
N=296\end{array}$ \\
\hline $\begin{array}{l}\text { underweight } \\
\text { normal weight } \\
\text { overweight } \\
\text { obesitas }\end{array}$ & $\begin{array}{l}<19 \\
19<Q \mid<26 \\
27<Q \mid<29 \\
Q \mid>31\end{array}$ & $\begin{array}{l}<18 \\
18<Q \mid<25 \\
26<Q \mid<28 \\
Q 1>29\end{array}$ & $\begin{array}{r}0 \\
82 \\
16 \\
2\end{array}$ & $\begin{array}{r}2 \\
87 \\
9 \\
2 \\
\end{array}$ & $\begin{array}{r}0 \\
80 \\
17 \\
2\end{array}$ & $\begin{array}{r}1 \\
83 \\
14 \\
2\end{array}$ \\
\hline mean & & & 23.57 & 23.07 & 23.60 & 23.41 \\
\hline
\end{tabular}


As can be seen in table 7.10 well over four fitths of the key health professionals fall into the normal weight ranges, as specified for males and females. While small proportions are overweight, obese key health professionals are hardly found. The Quetelet index is strongly related to age $\left(\mathrm{R}=.41^{* * *}\right)$.

\subsubsection{Manual hygiene}

The eleventh health behavior key health professionals were asked to report about was their manual hygiene before meals in terms of frequency of washing hands.

Table 7.11: Washing hands

\begin{tabular}{l|c|c|c|c|}
\hline $\begin{array}{l}\text { Do you usually wash } \\
\text { your hands before you } \\
\text { have meal? }\end{array}$ & $\begin{array}{c}\text { school- } \\
\text { teachers }\end{array}$ & $\begin{array}{c}\text { community } \\
\text { nurses }\end{array}$ & $\begin{array}{c}\text { general } \\
\text { practitioners }\end{array}$ & all \\
& $\mathrm{N}=98$ & $\mathrm{~N}=100$ & $\mathrm{~N}=99$ & $\mathrm{~N}=297$ \\
\cline { 2 - 5 } never & 3 & 0 & 7 & 4 \\
mostly not & 13 & 16 & 11 & 13 \\
often & 37 & 28 & 19 & 31 \\
always & 47 & 56 & 53 & 52 \\
\hline
\end{tabular}

As can be seen in table 7.11 the large majority of key health professionals ususally wash their hands always or in most cases, before they have a meal: no significant differences were found between the professional groups. Frequency of washing hands before meals increases with age $\left(r=.14^{\text {** }}\right)$.

\subsubsection{Safety belt use}

The last health behavior respondents were asked to report about was the use of seatbelts whille driving a car.

Table 7.12: Seatbelt use

\begin{tabular}{l|c|c|c|c|}
\hline $\begin{array}{l}\text { Are you using seatbelts } \\
\text { In your car }\end{array}$ & $\begin{array}{c}\text { school- } \\
\text { teachers } \\
\mathrm{N}=97\end{array}$ & $\begin{array}{c}\text { community } \\
\text { nurses } \\
\mathrm{N}=97\end{array}$ & $\begin{array}{c}\text { general } \\
\text { practitioners } \\
\mathrm{N}=96\end{array}$ & $\mathrm{~N}=290$ \\
\hline never & 6 & 7 & 6 & 7 \\
mostly not & 12 & 15 & 30 & 19 \\
often & 20 & 31 & 39 & 30 \\
always & 60 & 46 & 25 & 44 \\
mean & 3.4 & 3.2 & 2.8 & 3.1 \\
\hline
\end{tabular}

While three quarters of the respondents do use their seat-belts often or always, one quarter does not. Seat-belts are not regularly used by $18 \%$ of the school teachers, $22 \%$ of the community nurses and $36 \%$ of the general practitioners ( $\left.F=9.09^{* * *}\right)$. 


\subsubsection{Comparison of key health professlonals" health behavlor with the population}

In this paragraph the health behaviors of the Dutch key health professionals will be compared to those of the population at large in the Netherlands. In $1983^{,}$simultaneously with the survey among the key health professionals a survay among the population at large was carried out, reported about by Halfens, Philipsen \& Drop, 1984. Ten identical questions with regard to health behaviors discussed in 7.3.1 were used in that survey (the Quetelet Index and sleep had to be omitted in the population survey due to economical reasons). In table 7.13 the extent to which professionals' health behaviors diverge from the population's health behavior. Using the health norms explained in 7.3.3 all health behaviors were dichotomized in healthy and unhealthy behavior. The percentages found among the population at large were taken as base-line for showing the extent to which professionals differed. In interpreting table 7.13 , one should note that positive deviations from the horizontal axis sometimes imply that professional groups do more (e.g. breakfasting, use seat-belts), sometimes that they do less (e.g. smoke tobacco or drink coffee), depending on the health norms applied to the particular health behavior (see Appendix A, page 150).

Table 7.13: Health behaviors professional groups - population, Netherlands 1983

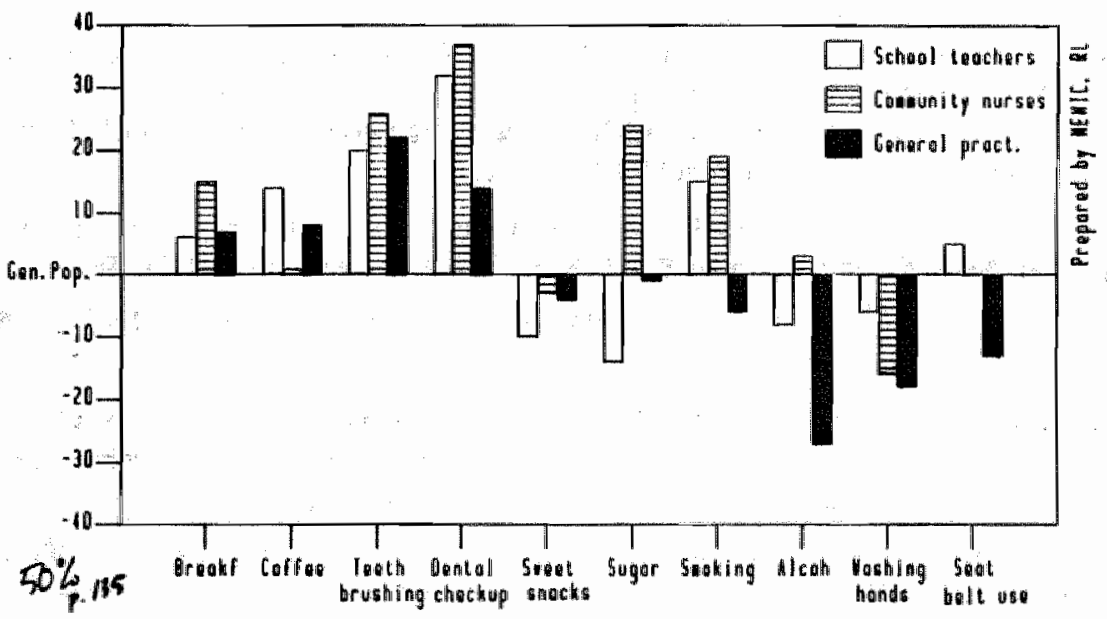

As can be seen in table 7.13 , more key health professionals regularly have breakfast than the general population. They drink less coffee, brush their teeth more often, see their dentist more frequently for a check-up. However, somewhat more key health professionals consume sweet snacks in between meals. Schoolteachers use more sugar in their coffee, while among schoolteachers and community nurses there are less current smokers. Among general practitioners there are more smokers than among the population at large. Compared to the general population, the frequency of immoderate drinking among schoolteachers and general practitioners is higher. Among community nurses the frequency of immoderate drinking is even lower; key health professionals wash their hands less often. In the population at large, seatbelt use is just as prevalent as among community nurses; schoolteachers use them more, general practitioners less frequently. 


\subsubsection{The health behavlor scale (HBS): Results}

As has been discussed amply in chapter 3 , the nature and dimensionality of health behavior is far from being established definitwely. In the next section an attempt to construct a health behavior scale will be described. The intercorrelations of all health behaviors were studied: only 26 of the 66 possible correlations were significant, while their size is modest, varying from 10 to .28 . When these correlations are inspected per professional group some reach up to .43 . The number of significant corralations ls restricted.

With regard to schoolteachers" health behavior, 13 out of 66 correlations are significant, among communily nurses 21, and among general practitioners only 12. Explorative factor analysis did not produce a common factor but a series of factors with Eigen values just above 1.0, unsuitable for interpretation. Reliability for scalle resulted in low Cronbach alpha's $(.30)$ for all groups.

\section{The correlational structure of the health behaviors}

Regularity of breakfasting appears to be related to snacking sweets in between meals, especially so tor teachers ( $\left.r=31^{* * *}\right)$, to non-smoking (especially for community nurses $r=-39^{* * *}$ ), to drinking immoderately (not for physicians), to washing hands and seatbelt use.

Coffee consumption is found to be positively related to smoking for schoolteachers and community nurses but not for general practitioners. It is positively related to alcohol consumption especially for general practitioners. Coffee consumption is negatively related to the length of sleep, except for teachers.

Teethbrushing is positively related to the frequency of dental checkups, to manual hyglene and seatbelt use, negatively to the use of sugar and the Quetelet Index.

Dental checkup (in addition to teethbrushing (rm-.28)) is negatively related to the use of sugar, but not tor teachers.

Snacking sweets in between meals (in addition to breakfasting, $(r=.10)$ is positively related to length of sleep, negatively to smoking and drinking. Among physicians no negative relationship botween drinking and swoet snacks is found.

Sugar intake through coffee is neglatively related to teeth brushing, dental checkups and the Quetelet Index. Whille smoking nurses tend to use less sugar, smoking teachers use more often sugar in their coffee.

Smoking is positively related to drinking coffee and alcoholic beverages. Smoking is negatively related to breakfast regularity, snacking sweets, sleep and seatbelt use. It is remarkable that among teachers those who smoke use more sugar and use their seatbelts less frequently.

Alcohol consumption in terms of frequency of drinking six glasses or more per day is positively related to coffoe consumption, smoking, and negatively to breakfasting. snacking sweets duration of sleep, washing hands and seatbelt use. it is remarkable that with the exception of schoolteachers, those health professtonals who drink more, tend to use their seatbelts to a lesser extent. For general practitioners a clear 
relationship with coffee and tobacco consumption was found, for nurses only with smoking, for schoolteachers with neither of the latter two health behaviors.

Length of sleep is positively related to snacking sweets, negatively to coffee, alcohol and tobacco consumption as well as to weight for height.

The Quetelet Index is positively related to teethbrushing and washing hands, negatively to sugar intake and length of sleep. The Quetelet Index and number of hours slept are negatively related, especially among general practitioners $(r=-34)$.

Washing hands is positively related to breakfasting, Quetelet Index, teethbrushing and negatively to drinking, especially among community nurses $(r-.43)$.

Seatbelt use is found to be positively related to breakfasting and teethbrushing, negatively to alcohol consumption, except for teachers, and to smoking, especially for the latter group ( $r=-.34)$.

In order to establish the associations with the latent variable HBS, the relationship of the 12 health behaviors with the proposed scale were calculated in terms of Pearsons corralations.

Table 7.14: Correlation of health practices with Health Behavior Scale Health behavlor

1. breakfast

2. coffee

3. teeth brusing

4. dental checkup

5. snacking sweets

6. sugar

7. smoking

8. alcohol

9. sleep

10. weight for height

11. washing hands

12. seat belt

\begin{tabular}{|c|c|c|c|}
\hline $\begin{array}{c}\text { school- } \\
\text { teachers }\end{array}$ & $\begin{array}{c}\text { community } \\
\text { nurses }\end{array}$ & $\begin{array}{c}\text { generall } \\
\text { practitioners }\end{array}$ & all \\
\hline $.22^{* *}$ & $.30^{* * *}$ & $.34^{* * *}$ & $.30^{* * * *}$ \\
$-.38^{* * *}$ & $-.29^{* *}$ & $-.32^{* * *}$ & $-.29^{* * *}$ \\
$.49^{* * *}$ & $.40^{* * *}$ & $.35^{* * *}$ & $.42^{* * *}$ \\
$.40^{* * *}$ & $.17^{*}$ & $.45^{* * *}$ & $.37^{* * *}$ \\
.0016 & $-.21^{*}$ & $.24^{* *}$ & $.15^{* *}$ \\
$.48^{* * *}$ & $.31^{* * *}$ & $.36^{* * *}$ & $.43^{* * *}$ \\
$.50^{* * *}$ & $.37^{* * *}$ & $.36^{* * *}$ & $.44^{* * *}$ \\
$.30^{* * *}$ & $.50^{* * *}$ & $.35^{* * *}$ & $.41^{* * *}$ \\
.06 & $-.29^{* *}$ & .05 & .06 \\
-.10 & -.11 & .02 & -.09 \\
$.20^{*}$ & $.23^{*}$ & $.40^{* * *}$ & $.30^{* * *}$ \\
$.43^{* * *}$ & $.38^{* * *}$ & $.44^{* * *}$ & $.43^{* * *}$ \\
\hline
\end{tabular}

As can be seen in table 7.14, with the exception of weight for height, all health behaviors correlated significantly with the HBS. Positive relationships are found with breakfasting. teethbrushing, dental checkups, washing hands, seatbelt use, consumption of coffer, sweet snacks, sugar, non-smoking and alcohol consumption. For sleep duration, a negative relationship was found only for nurses; among teachers and physicians, no such relationship was found. Because of the relationship of both sleep duration and Quetelet Index to mortality, shown by Breslow et al., both items will be maintained in the calculation of the Health Behavior Scale (HBS) to be explained in the next paragraph.

The realiability of this set of health behaviors appeared to be modest (KR-20-298). Due to the relatively homogeneous population, a modest reliability was to be expected. However, this is more of an indication about the population than a scale characteristic. 
Earlier on, on the basis of the evidence on their relationship to physical health status and mortality (Belloc \& Breslow, 1972; Belloc, 1973; Wiley \& Camacho, 1980; Berkman, Breslow \& Wingard, 1983) (for smoking, immoderate alcohol consumption, coffee consumption, snacking sweets, sleep and weight for height, seatbelt use), and on the basis of their directedness towards health maintenance (for preventive dental behavior and manual hygiene), it had been decided to calculate a sumscore called health behavior index (HBI), summarizing the dichotomized scores on the 12 health behaviors mentioned. In order to find a stronger underpinning of the GHB-concept, it was explored to what extent the data fit the Rasch model (Rasch, 1960; Meerling 1983, II).

Dichotomized items were analyzed by means of the PML-program (Gustafsson, 1977). The basic question whether the ltem group was homogeneous in the sense of the Rasch model could be answered positively. All these items appeared to fit with the Raschmodel. This means that the chance of a healthy" response decreases monotonously in the latent variable: "health behavior", which is being measured by means of the twelve items. Fitting the Rasch-model also implies that response patterns to the tweive items can be explained by the latent variable, allowing to rank items and individuals on one dimension. The resulting sumscore, the health behavior scale (HBS) is measured on internal level. An individual who has chosen the healthy alternative on the most difficult item, has a chance of .90 to respond positively to the easier items. The Rasch model is a demanding model: goodness of fit implies there is a hierarchical structure within the items, the response pattern has been made to. This means that once a respondent has given the 'healthy' response to the easiest item, there is a monotonously decreasing chance this respondent will choose the healthy response to the next more difficult item and so on towards the most difficult item (see fig. 1). The order of the health behavioral items found in Dutch key health professionals is given in table 7.16.

Table 7.15: Relative difficulty of health behavioral items as resulting from Rasch-model goodness of fit-test $(N=250)$

\begin{tabular}{llr}
\hline & Health behavior & Difflculty \\
\hline Easiest & 1. breakfast & 1.09 \\
& 2. weight for height & -0.90 \\
& 3. sleep & -0.53 \\
& 4. washing hands & -0.47 \\
& 5. brushing teeth & -0.42 \\
& 6. dental checkup & -0.18 \\
& 7. seat-belt use & -0.00 \\
& 8. colfer & +0.25 \\
& 9. sweet snacks & 0.66 \\
Most & 10. smoking & 0.76 \\
difficult & 11. alcohol & 0.93 \\
\hline
\end{tabular}

Among the health practices the consumption of sugar, alcohol, tobacco, sweet snacks and coffee are the most difficult ones; in that order. The Anderson conditional likelihood ratio test resulted in a Chi-2 of $17.14(\mathrm{df}=11 ; \mathrm{p}=0.103)$, which implies the health behavioral items can be considered as a interval scale (Adriaanse, Imbos \& Kok, 1988). 
It should be noted that the range of the HBS is limited to approximately - 1 to slightly over +1 . Ideally, a Rasch-scalle would range from -3 to +3 . Partly our relatively homogenoous population causes the restricted range. Nevertheless, more difficult and easier hems than those in the HBS currently added to the scale would extend the HBS-range. In the following table the results of the computation of the sumscore over the dichotomized health behavioral items is presented. The norms used for the criterion healthy/unhealthy are listed in Appendix A, page 150.

Table 7.16: $\quad$ Health Behavior Scale, per profession

\begin{tabular}{l|c|c||c|c|}
\hline Count & $\begin{array}{c}\text { schoot } \\
\text { teachers } \\
N=98\end{array}$ & $\begin{array}{c}\text { community } \\
\text { nurses } \\
N=100\end{array}$ & $\begin{array}{c}\text { general } \\
\text { practitioners } \\
N=100\end{array}$ & all \\
\cline { 2 - 5 } & 4 & 2 & 9 & 5 \\
6 & 7 & 5 & 11 & 8 \\
7 & 10 & 9 & 12 & 10 \\
8 & 25 & 14 & 25 & 22 \\
9 & 17 & 20 & 24 & 21 \\
10 & 26 & 29 & 12 & 23 \\
$>11$ & 9 & 21 & 7 & 12 \\
mean & 8.6 & 9.2 & 8.1 & 8.6 \\
\hline
\end{tabular}

In table 7.17 the distribution of the HBS is given per profession. As no population data on sleeping hours and weight for height were available, no comparison of professionals and populations HBS could be made.

While community nurses have the highest average HBS, followed by the schoolteachers, the group of the general practitioners have the lowest average HBS. Only $19 \%$ of the general practitioners have a high HBS, i.e. ranging from 10 to 12 , while this is the case for $50 \%$ of the community nurses and $35 \%$ of the schoolteachers. Average HBS-scores for community nurses ${ }_{\text {, }}$ schoolteachers and general practitioners are $9.4 ; 8.6$; and 8.0 $\left(\mathrm{F}=9.83^{* *}\right)$. Female professionals have higher average HBS-scores than male professionals (8.0 versus 9.3 , T-value $\left.=-6.91^{* * *}\right)$; the difference in average HBS for professional group membership is significant ( $\left.F=9.83^{* * *}\right)$.

\subsection{Discussion}

\subsubsection{Remarks with regard to our results}

The HBS as measured in this investigation consists of behaviors which are healthrelated (i.e. they have a relationship to morbidity and mortality or are health-directed (i.e. are preventive)). The criteria used to establish (un)healthiness of a specific behavior are rather conservative. For instance, the consumption of six glasses of alcohol containing beverages is no puritan norm. International alcohol researchers consider a range of 1 to 8 glasses per day as safe levels of alcohol consumption (Anderson, Cremona \& Wallace, 1984). We posit that our HBS is not influenced by more healthism than is healthy 
(Crawtord, 1980). An individual having a low HBS reports a really unhealthy lifestyle, made up out of changeable habits engaging him or her in otherwise preventable risk situations. On a thealth practices index of 7 points $86 \%$ of the American general practitioners had a score of 4 or higher. In our Dutch general practitioners sample, $80 \%$ had a score of midrange plus 1 or higher on the 12-points HBS.

The use of a summary score for health practices allows to explain more than can be explained by the health behavioral items separately, as has been defended by the Human Populations Laboratory (HPL) (Belloc, 1972; Belloc \& Breslow, 1973; Willey \& Camacho, 1980; Breslow \& Wingard, 1983). From regression analysis on five HPLpractices, Willey \& Camacho concluded no differential weighing was needed, although it was recognized that the influence of each health practice under study was not equal, the relative risk for smoking alone being 2.6 and highest, for all health practices 5.9 (Wingard, Berkman \& Brand, 1979). This finding supports the dichotomized inclusion of smoking, alcohol, sleep, and maintenance of proper weight in the HBS. The application of the Rasch model to our data concerning Dutch key health professionals' health behaviors, suggests that our addition of the seven health practices chosen, has resulted in a reasonably coherent hierarchical pattern of heaith behavior. In fact, this might be considered as empirical evidence for the "cascade"-concept of health behavior (Pill \& Stott, 1985). The main health behavioral items used in this research are all included in the National Health Interview Surveys carried out periodically by the Public Health Service in the USA. The NHII-surveys include typical HPL-items like snacking in between ineals and breakfasting, in spite of the inconclusive relationship to mortality (Thornberry, Wilson \& Golden, 1986). Compared to the HBS-survey, exercise is the core HPL-item that has been omitted in our study.

It should be noted that, if one would want to measure health behavior only inasfar as it is related to mortality, health practices preferably be weighed according to their relative risk, instead of assigning equal wieight to each health practice.

\section{Gender}

Female professionals appear to have a healthier lifestyle than male key health professionals. This seems to bias our results. Adjusted for gender, significant differences in HBS remain between the professional groups be it partly in reverse order. The purpose of our investigation was not, however, to establish whether male professionals live healthier than temale. If so dlisproportionate stratified sampling would have been necessary. Samples under study on the contrary, show a gender difference reflecting the gender distribution in the three professions. Therefore, it should be concluded that general practitioners, in the sex distribution as found in the Netherlands, have a less healthy lifestyle than community nurses and schoolteachers.

\subsubsection{Professionals - general population}

As professionals involved in health care and education can be assumed to be aware of the risk involved in unhealthy behavior, they were expected to have a healthier lifestyle than the population at large. The results concerning breakfasting, coffee consumption, preventive dental care confirm this expectation. It is surprising that professionals 
consume more sweet snacks in between meals, especially for schoolteachers who also use considerable more often sugar. Conform the expectation less schoolteachers and community nurses smoke than does the male, respectively the female part of the population. It is difficult to understand why general practitioners smoke more and have been observed doing so for at least a seven year period of time. An explanation could be found in the circumstance that physicians have most knowledge about the real possibilities for an individual to influence his or her own health status; also, general practitioners have a unique perspective on the role of change in the disease processes, their emergence and disappearance in human lives. This latter explanation is supported by the fact that general practitioners have slightly higher chance orientations then the population at large, when asked about health locus of control (Halfens, Adriaanse \& Philipsen, 1986). The extent to which over six glasses of alcohol are being consumed per day, could, as well as the smoking prevalence, be related to the longer working hours and work-related stress general practitioners experience. Social alcohol consumption, including drinking everyday, is more widely spread in the highest socioeconomic classes to which general practitioners belong while schoolteachers and community nurses belong to the first highest socio-economic class. Consumption of six glasses could surpass social drinking, though it does not necessarily mean one is a problem drinker either. Consumption of alcohol and tobacco constitute the major downers for the general practitioner and merit special attention.

Manual hygiene appears to be observed to a lesser extent by key health professionals than by the general population. This might be due to the fact that no major health threats are being transmitted in our society through dirty hands anymore. Washing hands before meals, therefore, could be seen as a void ritual more than as a preventive behavior, especially by the key health professionals. It could be that the general population is more susceptible to social desirability pressure in the field of hygiene than are key health professionals. For seatbelt use as with smoking it is true that general practitioners comply less with the health norms, adhered to in this study. This might be related to the fact that general practitioners as independent professionals - more so than schoolteachers and community nurses - are more reluctant to accept any infringement upon their liberty to make their own choices with regard to health.

\subsubsection{Comparison with earlier research}

In the next section results of previous investigations in the field of key health professionals' health behavior are compared with the results of the present study.

\subsubsection{Schoolteachers}

\section{Coffee}

Schoolteachers in the Netherlands drink about as much coffee as do teachers in Finland: $21 \%$ drinks 6 or more cups per day, while in Finland this was $25 \%$ (Kinnunen, Mäkinen \& Vihko, 1985).

\section{Smoking}

As in most countries the majority of the Dutch schoolteachers does not smoke. They smoke less than the general population. There are more smokers among male dutch 
schoolteachers than were recently found in most Western countries, with the exception of Japan where $60 \%$ of the schoolteachers smoked in 1981 . However, more smokers are found among female Dutch schoolteachers than among their colleagues in Asia and in the third world countries. They count a comparable number of smokers in North America and Scandinavia with the exception of Finland where only 3 to $8 \%$ of female teachers currently smokes (Adriaanse \& Van Reek, 1986).

\section{Alcohol}

Among Dutch schoolteachers less abstainers (10\%) are found than among Flemish $(24 \%)$ and Finnish teachers (20\%). No data allowing comparison of quantities of alcohol consumed were avaibale (Heyerick, Maes, De Maeseneer et al., 1981; Kinnunen, Makkinen \& Vihko, 1985).

No data were available to compare other health behaviors with those of the Dutch schoolteachers.

\subsubsection{Community nurses}

\section{Smoking}

While $41 \%$ of Dutch community nurses were current smokers in $198 \%$, the percentage found in 1983 was 31. Decline of smoking prevalence seems to go faster than among the Dutch female population. For male nurses not enough respondents were in the sample to allow comparison. The proportion of Dutch community nurses that reports to be currently smoking is comparable to most western countries. In southern Europe more nurses, especially hospital-based nurses smoke, while in Finland and Canada their number is appreciably smaller (Adriaanse, Van Reek \& Evers, 1986).

\section{Alcohol}

Among Dutch community nurses only $12 \%$ are abstainers. In a study of American nurses $55 \%$ was reported to drink regularly. Immoderate alcohol consumption (over six glasses per day) was reported by $47 \%$ of the American nurses (Haack \& Harford, 1984). Only $40 \%$ of the Dutch community nurses ever drinks six or more glasses per day.

No other data were avalable to compare other health behaviors with those of the Dutch community nurses.

\subsubsection{General practitioners}

\section{Coffee}

Dutch general practitioners drink more cups of coffee than did their colleagues at Johns Hopkins Medical School over the last 20 years, while the latter drank approximately three cups a day, $51 \%$ of the Dutch general practitioners drank four cups a day, $31 \%$ drank six and more cups a day. The conservative mean of 4.5 cups a day would mean Dutch general practitioners drink $50 \%$ more cottee than their American colleagues (Thomas, Santora \& Shafer, 1979). 


\section{Breakfast}

In two American studies respectively 4 and $25 \%$ of the general practitioners under study reported to skip breakfast always or mostly. Among Dutch general practitioners this was 13\% (Glanz, 1982; Wyshack ot al., 1980).

\section{Snacking}

Glanz, Fiel, Walker \& Levy (1982) reported $39 \%$ of the general practitioners did never of seldom use snacks between meals. Among Dutch general practitioners $61 \%$ never or rarely consumed sweet snacks.

\section{Smoking}

More Dutch general practitioners smoke than do males in the general population, especially more than males in the highest socio-economic bracket. Smoking prevalence is decreasing among general practitioners, but slower and later than among the male population (Adriaanse, Van Reek \& Metsemakers, 1985). Too few female respondents were in the study to allow comparison. More Dutch general practitioners are current smokers than general practitioners in comparable countries. In most countries large majorities of physicians are non-smokers (Adriaanse, Van Reek \& Van Zutphen, 1986).

\section{Alcohol}

Most studies referred to in the literature review (chapter 3) concern alcoholism; no data on regular consumption among representative general practitioner samples are available to allow direct comparison. Among Dutch general practitioners $3 \%$ are abstainers, as many as was found for Japanese general practitioners (Kono, keda, Ogata, Tokodume, Nishizumi \& Kuratsune, 1983), and less than among American general practitioners. Niven, Hurt, Morse \& Swenson (1984) tound $12 \%$, Wyshak, Lamb, Lawrence \& Curran (1980) found $5 \%$ abstainers among them. Lens (1984) found $19 \%$ of his Dutch general practitioner sample to be potentially endangered by alcoholism. Our finding that $64 \%$ of the general practitioners sometimes, and $9 \%$ once to thrice per week consume six glasses or more, suggests reasons for concern.

\section{Sleep}

General practitioners in the Netherlands on the average sleep 7.4 hours a day. Seventeen percent sleeps less than 7 hours. Of American general practitioners $23 \%$ sleeps less than 8 hours (Wyshak, 1983). Glanz found 75\% sleeps 7 or 8 hours; for Dutch general practitioners this was $79 \%$ (Glanz, 1982), which means that Dutch general practitioners sleeping habits do not differ significantly from those of their North American colleagues.

\section{Quetelet Index}

In 1982 Lens found among Dutch general practitioners only $4 \%$ to be overweight, while among the highest socio-economic bracket in the population $13 \%$ was reported to have a Quetelet Index >27 (Kok, Matroos \& Vandenbroucke, 1981). Kasanov (1976) found 10\% of the general practitioners to be overweight. 
Lens' remark that respondents most likely gave flattered responses to questions on their weight might be true: in our survey $17 \%$ of the general practitioner was overweight (27<Ol>29) and $2 \%$ obese (Ql> 30$)$.

\section{Seatbelt use}

Among Dutch general practitioners $64 \%$ always or often use their safety belts while driving a car which they all do. Wyshak ot al. report American general practitioners to use their seatbelts more frequently than lawyers, without revealing exact figures. "Possible the experience of general practitioners in emergency rooms accounts for their greater recognition of the value of seatbelts" (Wyshak et al., 1980). General practitioners are more likely to be in emergency rooms than teachers and community nurses; this background does not explain the relatively low usage of seatbelts among Dutch general practitioners. It is remarkable that general practitioners show a high smoking prevalence and a relatively low seatbelt use.

No data were avaliable to compare other health behaviors with those of the Dutch general practitioners.

\section{Correlational structure of key health professionals' health behavior}

As among the general population intercorrelations between health behaviors within individuals were found to be low among American general practitioners (R's ranging from $.10^{*}$ to .14"), (Glanz, 1982B). Most often significantly associated with other health practices was breakfasting. Each separate health behavior with the exception of alcohol consumption, was highly significantly correlated with the total number of health behaviors. (Pearson's correlations $.26^{*}$ to $.44^{*}$ ). Positive correlations of smoking with alcohol and coffee consumption and skipping breakfast had been found regularly (Istvan \& Matarazzo, 1984; Wingard \& Berkman, 1983).

Our findings that length of sleep and maintenance of proper weight in terms of the Quetelet Index are not associated with HBS as were all other health practices, seems to disturb a homogeneous health behavior pattern. Both for length of sleep and for maintenance of proper weight it is true that a low and a high zone are considered to be unhealthy; a midzone is considered to be healthy (see Appendix A). Other health practices can assume values in one direction: elther more or less of the concerned health practices is healthy. In the case of length of sleep and maintenance of proper weight unhealthy values to in two directions. Too little sleep as well as too much sleep, to be too heavy (obese) as well as to be too light (anorectic) is unhealthy. This $\mathrm{N}$-shaped distribution of the association between health on the one hand and sleep and weight maintenance on the other hand, explains the specific position of these health behaviors.

It is remarkable that no association between smoking and Quetelet Index was found in any professional group. Mostly smokers have reduced body weight. This might be due to a combined effect of smoking on both lung function and metabolism, eventually predisposing for COLD (Nemery et al., 1983).

On the correlational structure of health behavior in nurses and teachers no data are available as yet. 


\subsection{Conclusions}

1. Dutch community nurses have a healthier lifestyle than Dutch schoolteachers; general practitioners have the least healthy lifestyle, especially due to their alcohol and tobacco consumption.

2. The HBS reflects a reasonable coherent number of in itself unsimilar behaviors related and/or directed to health. The HBS appears to reinforce a number of do's (breakfast, dental prevention, hygiene, seatbelt use), or don's (smoking), or don't too much (coffee, snacking sweets, sugar, weight, alcohol) and of don't too less or too much (weight for height, sleep). The HBS was proven to be a useful instrument to measure the extent to which an individual has a healthy lifestyle, due to its reasonable goodness of fit with the Rasch model.

\subsection{Summary}

In this chapter the results of the measurements of key health professionals' health behaviors are presented. Twelve health behaviors, including breakfasting, coffee-, sugar-, tobacco-and alcohol-consumption, dental hyglene and -checkup, sleeping thabits, maintenance of proper weight, manual hygiene and seatbelt use are used to construct a Health Behavior Scale (HBS), on the basis of the Rasch-model. Ninety percent of the key health professionals takes breakfast regularly. Community nurses drink slightly more coffee than do teachers and physicians. Over three quarters of the key health professionals brush their teeth two or three times a day and goes for a dental checkup twice a year. Forty percent consumes sweet snacks in between meals. Community nurses less often use sugar than do teachers and physicians. More general practitioners (56\%) smoked than teachers and nurses (36\% and $31 \%)$. Immoderate drinking is less frequent among nurses, than among teachers and physicians. Average sleep duration of all key health professionals is eight hours. Most key health professionals have Quetelet Indexes in the acceptable range. Although no underweight, an average of $14 \%$ overweight was found. Most key health professionals wash their hands before meals. Seatbelts were not used by $18 \%$ of the teachers, $22 \%$ of the nurses and $36 \%$ of the general practitioners.

Key health professionals behaved more according to the health norms set than the population at large concerning breakfasting, coffee consumption, dental hygiene and dental checkup. They consume more sweet snacks in between meals. Only nurses use less sugar, less teachers and nurses, more general practitioners are found to be current smokers than these proportions in the population at large. Teachers and physicians more frequently, nurses less frequently than the general population drink six glasses of alcoholic beverages per day. Intercorrelations of health behavior were low; correlations with the Health Behavior Scale were mostly sizeable and positive. Testing of the goodness of fit of the health behavior data with the Rasch-model showed a hierarchy in the difficulty of the health behavioral items and resulted in the construction of a Health Behavior Scale with a restricted range. On the whole, general practitioners have a somewhat less healthy lifestyle than teachers and nurses. In as far as possible a comparison is made with related data from other countries. 


\section{References}

Adams, J.; 1985. Smeed's law, seatbelts and the emperor's new dothes. In: Evans, L. \& Schwing. R.C. (Eds.), Human behavior and traffic salety. Plenum Press, New York, 123-248.

Adriaanse, H., Imbos, T., Kok, G.J., 1988. A new approach of the dimensionality of health behavior. In preparation.

Adriaanse, H., Van Reek, J., Metsemakers, J., 1986. Smoking behavior of Dutch generall practitioners 1977-1983. Scandinavian Joumal of Primary Health Care, 4, 151-156.

Adriaanse, H., Van Feek, J. \& Van Zutphen, W.M., 1986. Rookglewoonten van artsen wereldwijd: een overzicht wan 100 onderzoekingen naar tabaksgebruik onder artsen in 31 landen in de periode 1951-1985. Nederlands Tijdschrift voor Geneeskunde, 130, 49, 2224-2229. (Physicians" smoking worldwide).

Anderson, P., Cremona, A., Wallace, P., 1984. What are safe levels of alcohol consumption? British Madical Journal, 289, 1657-1658.

Arkel, W.G. van, Sturmans, F., 1985. Roken en ziekle. Nederlands Tijdschrift voor Geneeskunde, 23, 10B1-1085. (Smoking and disease).

Belloc, N.B. 1973. Relationship of health practices and mortality. Preventive Medicine, 2, 67-81.

Belloc, N.B., Breslow, L., 1972. Relationship of physical health status and health practices. Preventive Medicine, 1, 409-421.

Berkman L.F., Breslow, L. Health and ways of living. The Alameda County Study. Oxford University Press: Now York.

Berkman, L.F., Breslow, L., Wingard, D., 1983. Health practices and mortallity risk. In; Berkman \& Breslow, 1983; 0.c., p. 61-112. Bray, G.A., 1985. Obesity: definition, diagnosis and disiedvantages. Medicall Journal of Australia, 142, 2-8.

Bray, G.A., 1985. Obesity: definition, diagnosis and disadvantages. Medical Joumal of Australia, 142, April 1st, 2-8.

Breslow, L., Enstrom, J., 1980. Persistence of health habits and their relationsips to mortality. Preventive Medicine; 9, 469-483.

Castelli, W.P., 1979. How many drinks a day? Journal of the American Medical Association, 18, 2000.

Crawford; $R, 1980$. Healthism and the medicalization of everyday life. International Joumal of Health Sorvices, 10, 3, 365-388.

Curatolo, P.W., Robertson, D., 1983. The health consequences of caffeine. Annals of Internal Modicine, 11, 641-653.

Dawber, T.R., Kannel, W.B., Gordon, T., 1974. Coffoe and cardlovascular disease. New England Journal of Medicine, 871-874.

Doll, ., Hill, A.B., 1964. Mortality in relation to smoking: ten years' observatione of British doctors. British Medical Joumal $1,1399-1410 ; 1460-1467$.

Dyer, A.P., Stamler, J., Oglesby, P., Lepper, M., Shekelle, R.B., McKean, H., Garside, D., 1980. Alcohol consumption and 17-year mortality in the Chicago Western Electric Company study. Preventive Medicine i $9 ; 88-90$. 
Eykman, M.A.J, Visser, A.P., 1987, Patientenvoorlichting en de tandarts. Bohn, Scheltema \& Holkema: Utrecht. (Patient education and the dentist).

Fabry, P., Tepperman. J., 1970. Meal frequency - a possible factor in human pathology. American Joumal of Clinical Mutrition, $23_{1} 8,1059-1068$.

Glanz, K., Fiel, S.B., Walker, L.R.G., Lev, M.R., 1982. Preventive health behavior of physicians. Journal of Medical Education, 5, 63-79.

Gustafsson, JE., 1977. The Rasch-model for dichotomous items: theory, applications and a computer program. Reports from the Institute of Education. University of Gotenburg.

Haack, M.R., Harford, T.C., 1984. Drinking patterns among student nurses. International Joumal of Addictions, 5, 577-583. Halfens, R., Adriaanse, H. Philipsen, H., 1986. Health perceptions of nurses, physicians and patients with regard to personal control. Program and Abstracts Third Open Nursing Research Conference, Helsinki, p.27.

Halfens, R., Drop, M.J., Philipsen, H., 1984. Leetwijzen en subjektieve gezondheid van panel uit de Nederlandse bevolking. Zeist/Maastricht, University of Limburg. (Lifestyle and subjective health of a panel from the Dutch population).

Hammond, E.C., 1966. Smoking in relation to the death rates of one million men and women. National Cancer Institute Monographs, 19, 127-204.

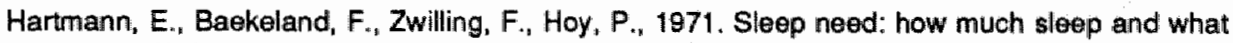
kind? American Journal of Psychiatry, 127, 1001-1008.

Hennekens, C.H., Willett, W., Rosner, B., Cole, D.S., Mayrent, S.L., 1979. Effects of beer, wine and liquor in coronary deaths. Journal of the American Medical Association, 242, 19731974.

Heyden, S., Schneider, K.A., Ruh, J., Fodor, G.J., 1986. Habitual coffee consumption and cholesterol levels. Heart Beat, 4-6.

Heyden, S., Tyrder, H., Heiss, G., Hames, C.G., Bartel, A., 1978. Coffee consumption and mortality. Archives of Internal Medicine, 138, 1472-1475.

Heyerick, J.P., Maes, L., De Maeseneer, J.P., 1981. Gezondheid, je kan er zelf iets aan doen. Diensten van de Eerste Minister, Wetenschaps beleid, Brussels. (Health, your responsibility: a feasibility study).

Istvan, U., Matarazzo, J.D., 1984. Tobacco, alcohol and catfeine use" review of their interrelationship. Psychological Bulletin, 2, 3014306.

James, W.P.T., 1976. Research on obesity. DHSSMedical research Council, Her Majesty's Stationary Office, London.

Janssen, W.H., 1987. Effekten van risikokompensatie. Instituut voor Zintuigfysiologie Soesterberg. (Effects of risk compensation).

Kannel, W.B., 1977. Coffee, cocktails and coronary candidates. New England Journal of Medicine 8, 443-444.

Kannel, W.B., 1967. Habitual level of physical activity and risk of coronary heart disease: the Framingham Study. Canadian Modical Association, 96, 811-812.

Kannel, W.B., 1971. Habits and heart disease. In Palmore, E., Jeffers, F.C. (Eds.), Prediction of life span. Heath Lexington Books: Lexington MA, Chapter 5. 
Kannel "W.B., LeBaver, J.E., Dawber, T.R., MelNamara, P., 1967. Relation of body weight to development of coronary heart disease. Circulation $35,734-744$.

Kasanov, D., 1976. How doctors take care of themselves. (Special Survey). Patient Care, 8, 49-69.

Keys, A. Aravanis, C., Blackbum, H., Buchem, F.S.P. van, Buzina, R., Djordjevic, B.S., Fidanza, F., Karvonen, M.J., Menotti, A, Puddu, V., Taylor, H.L. .1972 Coronary heart disease: overweight and obesity as risk factors. Annals of Intemal Medicine, 77, 15-27.

Kinnunen, $U$, Makinen, $R_{2}$, Viliko, $V_{,}, 1985$. The level of teacher stress over a school year. Reports from the Institute for Ectucational Research nr. 363, University of Jyviskyt: Jywàskylä.

Knibbe, $R_{i}$ ॥984. Van gangbaar tot problematisch drankgebruik. Dissertation, University of Limburg, Maastricht. (From convivial to problematic alcohol consumption).

Knipschild, P., 1984. Alcohol als hartversterker. Nederlands Hart Bulletin. (Alcohol, strengthening the heart).

Kok, F.J., Matroos, A.W., Vandenbroucke, J.P., 1981. To zwaar of niet te zwaar. Vooding, 8, 262269. (Obese or not?)

Kono, $\mathbf{S}_{.,}$Keda, M., Ogata, M., Tokodume, $\mathrm{S}_{\text {, }}$ Nishizumi, M, Kuratsune, M., 1983. The relationship between alcohol and mortality among Japanese physicians. Intemational Journal of Epidemiology, 4, 437-441.

Kozararevic, D., McGee, D., Vojwodic, N., Dawber, T., Pacic, Z. "Gordon, T., 1980. Frequency of alcohol consumption and morbidity and mortality: the Vugoslavia cardiovascular disease study. Lancet $1980,613-616$.

Kripke, D.F., Simons, R.N., Garfinkel, L., Hammond, E.C., 1979. Short and long sleep and sleeping pills: is increased mortality associated? Archival of General Psychiatry, 36, 103116.

Kristiansen, C.M., Harding, C.M., 1984. The measurement of preventive health behavior. Paper University of Exeter.

LaPorte; R.E. Cresanta, J.L., Kuller, L.H., 1980. The relation of alcohol to coronary heart disease and mortality: implications for public health policy. Journall of Public Health Policy, 1, 198 223.

Levinson, M.L., 1977. Obesity and health. Preventive Medicine, 6 (1), 172-180.

Marmot, M.G., Rose, G., Shipley, M.J., Thomas, B.J., 1981. Alcohol and mortality: a U-shaped curve. The Lancet, March 14, 580-583.

Meerling. 1283. II. Methoden en technieken van psychologisch onderzoek. Deel II. Boom: Meppel. Hooldstuk V. Analyse van dominantiedata: probabilistische modellen. P. 140-159.

Murray, S.S., Bjelke, E. Gibson, R.W. Schuman, L.M., 1981. Coffee consumption and mortality from ischaemic heart disease and other causes: results from the Lutheran Brotherhood study. American Journal of Epidemiology, 113, 661-667.

Nemery, B. "Moavero, N.E. Brasseur, L, Stanescu, D.C., 1983. Smoking, lung function and body weight. British Medical Journal, 286, 249-251.

Nichols, J:L, 1982. Effectiveness and efficiency of safety belt and child restraint usage programs. NHTSA Technical Reports NTIS, Springfield. 
Niven, R.G., Hurt, R.D., Morse, R.M., Swenson, W.M., 1984. Alcoholism in physiciens. Mayo Clinical Proceodings, 59, 12-16.

Oswald, 1., 1976. The function of sleep. Postgraduate Medical Joumal , 52, 15-18.

Pill, R., Blott; N.C.H., 1985. Preventive procedures and practices among working dass women. New data and fresh insights. Social Sclence \& Medicine, 9, 975-983.

Rasch, G., 1960. Probabilistic models for some intelligence and attainment tests.. Danish Institute for Educational Research: Copenhagen.

Room, R., Day, N., 1974. Alcohol and mortality. National Institute on Alcohol Abuse and Alcoholism: Rockville, MD.

Royal College of Physicians, 1972. Smoking and Health. Pitman Medical, London.

Schmidt, W., 1980. Effects of alcohol consumption on health. Journal of Public Health Policy, 1, 25-40.

Schuurs, A.H.B., 1986. Verplichte halfjaarlijkse gebitskontrole. Nederlands Tijolschrift woor Tandheelkunde. (Mandatory biannual dental check-up).

Sleet, D.A., 1984. Reducing motor vehicle trauma through health promotion programming. Health Education Quarterly, 2, 113-125.

Smits, P.A.B.M., 1986. Coffee and bloodpressure. Thesis, University of Nijmegen.

Thomas, C.B., Santora, P.B. Shafer, J.W., 1980. Health of physicians in midlite in relation to the use of alcohol: a prospective study of a cohort of former medical studients. The Johns Hopkins Medical Journal 1, 1-10.

Thornberry. O.T., Wilson, R.W., Golden, P., 1986. Health promotion data for the 1990 abjectives: estimation from the national health interviow survey of health promotion and disease prevention. USA, 1985, Advance Data, 126, 1-16.

Van Groenestijn, M.A.J., Maas-De Waal "C.J., Swallow, J.N., Mileman, P.A., 1979. Regelmatig niet regelmatig tandartsbezoek. Tijdschrift voor Sociale Geneeskunde, 57, 369-375. ((Non)regular dental visits).

Wiley, J.A., Camacho, T.C., 1980. Lifestyle and future health: evidence from the Alameda County Study. Preventive Medicine, 9, 1-21.

Wingard, D., Berkman, L.F., 1983. A multivariate analysis of health practices and social networks. In: Berkman, L.F. \& Bresilow. 0.c., 161-175.

Wyshak, G., Lamb, G., Lawrence, R.S. Curran, W.Y., 1980. A profile of health promoting behaviors of physicians and lawyers. New England Journal of Medicine, 2, 104-107. 


\section{Appendix A}

Health practices correlations with HBI Norms used for the dichotomization of ten health behaviors

\begin{tabular}{lll}
\hline Health behavlor & Healthy & Unhealthy \\
1. Breakfasting & Always-regularly & Hardly ever-never \\
2. Coffee consumption & Incl. 5 cups a day & 6 Cups and more a day \\
3. Teeth brushing & $2-3$ times a day & Less \\
4. Dentist visits & Bi-annually & Less \\
5. Sweet snacking & Hardly ever-never & Mostly-always \\
6. Sugar in coffee & Sometimes-never & Mostly-always \\
7. Smoking & No & Current \\
8. Alcohol & Never more than & More than six glasses \\
& 6 glasses a day & a day \\
9. Sleeping hours & 7 hours time & Less than 7 hours \\
& $83 / 4$ & More than 9 hours \\
10. Weight for height & Females $>25.9$ & $<18 ;>26$ \\
Quetelet Index & Males $>26.9$ & $<19 ;>27$ \\
11. Washing heands & Mostly/always & Never/sometimes \\
12. Safety belt use & Mostly/always & Never/sometimes \\
\hline
\end{tabular}




\section{Chapter 8.}

\section{Exemplary role: results}

8.1 Introduction

8.2 Operationalization of the exemplary role

8.3 Perception of the exemplary role

8.4 Discussion

8.4.1 Method

8.4.2 Results

.4.3 Previous results

8.5 Conclusions

8.6 Summary 


\subsection{Introduction}

In this chapter the third central question will be dealt with: "Do key health professionals recognize that they are part of other's social environment and have a speclal position in it; thus can influence the health behavior of these others more strongly?" In other words, do professionals perceive any exemplary role for themselves?

As has been shown in the review of the literature pertaining to the exemplary role conceptualization and recognition, the exemplary role is primarily a common sense notion not conceptualized very meticulously. Moreover, it has been used frequently in discourses of persuasive nature. It has hardly been operationalized to be applied in research settings. So it was necessary in this investigation to do a proposal for an instrument to measure the perception of the exemplary role by the key health professionals. In the next sections a six-item scale for the measurement of the extent to which professionals in health care and education recognize an eventual exemplary role is presented as well as the results obtained using it.

\subsection{Operationalization of the exemplary role}

The perception of the exemplary role was operationalized by six dichotomous items pertaining to individual health behavior. Half of these items are related to example setting with regard to health in general, half pertains to three core health issues, i.e. smoking, drinking and nutrition. The formulation of the statements has been adapted to the specific circumstances in the three professions under study; these six statements were part of a longer list of items, all pertalining to the broad domain of health behavior and responsibility for health. The EXR items were dispersed within the list, so the dimension of the recognition of an eventual examplary role was not immediately visible. The tiems were formulated in the personal "I"-mode, so as to avoid general, socially acceptable answers.

Proportions of professionals agreeing with the statements are presented in the cells. 
Table 8.1 Recognition of the exemplary role with regard to health behavior per profession

Statement on exemplary role

1. With my own health behavior I consciously set an example to my pupils/patients

2. If I give advice, it does not matter whether I smoke as long as I tell my patients what is beneficial for them

3. It does not matter how much I drink myself, as long as I convince the youth not to start too young with drinking alcohol

4. My pupils/patients observe my health behavior to such limited extent that it cannot be influentia

5. How much and what I eat has nothing to do with my profession; my pupils /patients do not see it

6. The lifestyle I practise outside my work is in no way relevant for my pupils/patients

7. If I had tried drugs myself, who am I to warn my patients against them

\begin{tabular}{|l|c|c|c|}
\hline \multicolumn{4}{|c|}{ Agreement (percentages) } \\
\hline $\begin{array}{l}\text { School } \\
\text { teach. } \\
\text { N=101 }\end{array}$ & $\begin{array}{c}\text { Comm. } \\
\text { nurses } \\
\text { N-100 }\end{array}$ & $\begin{array}{c}\text { Gen. } \\
\text { pract. } \\
\text { N-98 }\end{array}$ & $\begin{array}{c}\text { Chi-2 per } \\
\text { statement }\end{array}$ \\
\hline 55 & 40 & 22 & $22.43^{* * *}$ \\
21 & 53 & 61 & $37.86^{* * *}$ \\
35 & 52 & 51 & $7.9^{*}$ \\
47 & 53 & 69 & $10.80^{* *}$ \\
50 & 38 & 49 & 4.34 \\
37 & 45 & 57 & $7.9^{*}$ \\
32 & 28 & 18 & p.m. \\
\hline
\end{tabular}

Teachers appear to agree mostly with the statement that with their own health behavior they consciously set an example to their pupils, community nurses do so to lesser extent to their patients, while only $22 \%$ of the general practitioners agreed. A majority among the general practitioners and among the community nurses did not see the necessity of congruence between personal health behavior and professional performance with regard to smoking and drinking. Considerable proportions of schoolteachers, community nurses and general practitioners do not consider this congruence necessary with regard to nutrition. Clearly more teachers consider their lifestyle relevant to their pupils than community nurses and general practitioners do for their patients.

As mentioned already, the items used for the measurement of exemplary role recognition were part of a longer list containing statements about health behavior and responsibility for health. Seven of these items pertained to the exemplary role. One item pertaining to drug use was removed because the use of drugs was virtually non-existent: respectively one, one and four percent of teachers, nurses and physicians reported to use drugs seldomly or sometimes. Secondly the item had a loading of less than .30 on the first factor. The results of the factor analysis are shown in table 8.2. 
Table 8.2: Factor loadings of EXR items on first factor

\begin{tabular}{|c|c|c|c|c|c|}
\hline & them $\mathrm{nr}$. & $\begin{array}{l}\text { School } \\
\text { teachers }\end{array}$ & $\begin{array}{c}\text { General } \\
\text { pract. }\end{array}$ & $\begin{array}{c}\text { Community } \\
\text { nurses }\end{array}$ & $\begin{array}{c}\text { All protes- } \\
\text { sionals }\end{array}$ \\
\hline 1. Set axamplo & them 1 & .52 & .58 & .01 & .45 \\
\hline 2. EXR/smoke & item 2 & 43 & .71 & .76 & .70 \\
\hline 3. EXR/drink & hem 3 & .72 & .71 & .77 & .73 \\
\hline 4. EXR/HB & them 4 & .69 & .66 & .46 & .63 \\
\hline 5. EXR/eat & item 5 & .55 & .57 & .69 & .55 \\
\hline 6. Lhestyle & item 6 & .44 & .58 & .57 & .56 \\
\hline \multirow{3}{*}{\multicolumn{2}{|c|}{$\begin{array}{l}\text { variance explained } \\
\text { Eigen-value } \\
\text { Cronbach"s alpha }\end{array}$}} & $32 \%$ & $41 \%$ & $36 \%$ & $37 \%$ \\
\hline & & 1.94 & 2.46 & 2.18 & $=$ \\
\hline & & .57 & .71 & .59 & .65 \\
\hline
\end{tabular}

The overall Cronbach's alpha value was .65 , which is acceptable. The inter-item correlations ranged between .09 and .51 with a mean of .24. In table 8.3 the item-total correlations are shown.

Table 8.3: Corrected item total correlations of EXR items

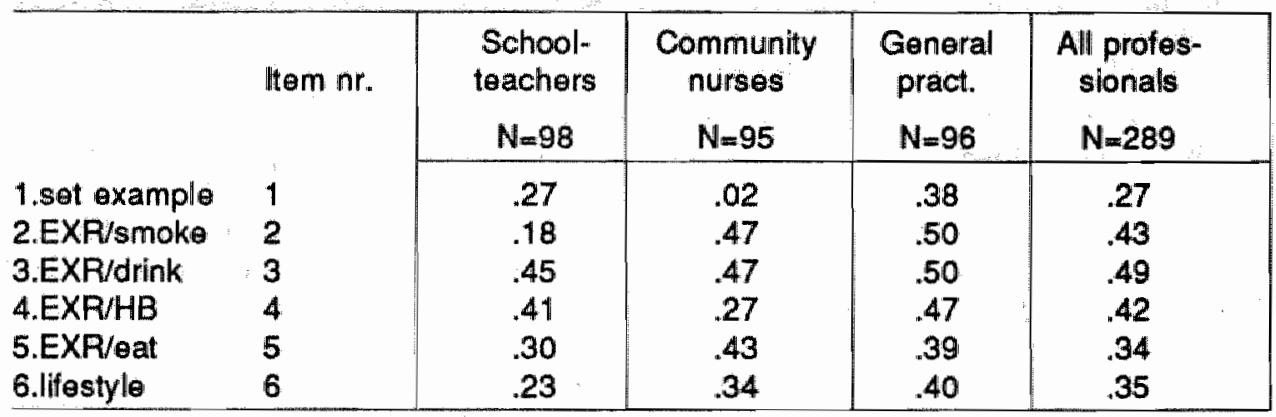

Overall ftem-total correlations range between .27 and .49. The first EXR item, pertaining to the conscious setting of an example by personal health behavior, showed a very low value among nurses, for which no explanation could be found. Because of the importance of its content, and because of the finding that by its deletion the overall Cronbach's alpha would not be affected, this item was nonetheless maintained as a part of the EXR-scale.

On the basis of the factor-and reliability analysis it was justified to calculate a sumscore representing the perception of the exemplary role. This new variable entitled exemplary role recognition was defined as professionals' perception of his or her personal health behavior and lifestyle in relation to the target groups' health behavior, including its percelved impact on the population at large. 


\subsection{Perception of the exemplary role}

In table 8.4 the distribution of exemplary role recognition (EXR) in the three professional groups is shown.

Table 8.4: Exemplary role recognition, per profession (\%)

\begin{tabular}{l|cccc|}
\hline EXR score & $\begin{array}{c}\text { All profes- } \\
\text { sionals } \\
\mathrm{N}=290\end{array}$ & $\begin{array}{c}\text { School- } \\
\text { teachers }\end{array}$ & $\begin{array}{c}\text { Community } \\
\text { nurses }\end{array}$ & $\begin{array}{c}\text { General } \\
\text { practitioners }\end{array}$ \\
\cline { 2 - 5 } 0 & 10 & 2 & $\mathrm{~N}=98$ & $\mathrm{~N}=95$ \\
\hline & 15 & 10 & 7 & 23 \\
2 & 16 & 12 & 19 & 17 \\
3 & 19 & 23 & 15 & 20 \\
4 & 15 & 19 & 19 & 14 \\
5 & 17 & 21 & 18 & 11 \\
6 & 8 & 14 & 5 & 4 \\
mean & 3.0 & 3.6 & 2.9 & 2.3 \\
\hline
\end{tabular}

As can be seen the distribution of exemplary role recognition ameng community nurses is fairly equilibrated, while among schoolteachers it is somewhat skewed to the higher ranges and among the general practitioners it is skewed towards the lower ranges. If dichotomized by means of the overal median (3), it can be seen that while $54 \%$ of the schoolteachers and $41 \%$ of the community nurses show a considerable extent (EXR $=4$ to 6) of exemplary role recognition, only $27 \%$ of the general practitioners do so. The reliability for scale varied between .57 and .71 , which was considered acceptable. Analysis of variance confirmed the existence of significant differences between the average exemplary role recognition-scores of all three professional groups ( $\left.F=12.68^{* * * *}\right)$. $\left.\mathrm{T}(\mathrm{ST}, \mathrm{CN})=2.93^{* *} ; \mathrm{T}(\mathrm{ST}, \mathrm{GP})=5.46^{* * *} ; \mathrm{T}(\mathrm{CN}, \mathrm{GP})=2.59^{* *}\right)$.

\subsection{Discussion}

\subsubsection{Method}

The instrument used to measure exemplary role recognition was constructed post-hoc from a number of items taken with good reasons (i.e. content, factor loading and reliability criteria) from a larger list of statements related to health behavior and professional responsibility. This circumstance might be considered as an advantage, because it avoids cueing respondents towards clearly discernable and socially desirable directions. Though the data presented justify the conclusion that a useful variable was created, a few other disadvantages might mitigate its value. First, the level of aggregation differs: while three items pertain to lifestyle in general, three items pertain to specific health behaviors (drinking, smoking, nutrition). The use of less general and as a consequence more diversified specific health behavior items might have enhanced the content validity of the measurement of exemplary role recognition. The exemplary role 
recognition items were presented surrounded by a majority of affirmatively formulated statements; however, four out of six were negatively formulated which might create a response tendency when used independently in another context.

\subsubsection{Results}

Exemplary role recognition was lowest among general practitioners, average among community nurses and highest among schoolteachers. If one considers the amount of time each of these professionals spends along with his/her target groups, this tendency is not surprising. A general practitioner who sees a patient on the average for 7 minutes, often just three or four times a year, cannot possibly be as influential as a schoolteacher who, in elementary school, relates to the pupils every day of the schoolyear. Community nurses, if one considers their maternal and child care tasks or care for the elderly, spend more time and see the patients more often than the general practitioner. The reason for encounter for a meeting with a general practitioner, a community nurse or a schoolteacher being an entirely different one, it is less understandable why general practitioners would have such low exemplary role recognition scores. Is it not the medical profession itself which is claiming a unique position towards their patients, because of its knowledge of the patient's history, present expectations and the physicians' skills and knowledge? The patient being extremely captive due to the physical and mental state inducing the visit, the general practitioner being well prepared and knowledgeable about health behavior, the encounter might be seen as a fertile soil for health education interventions, be these strategic and verbal or of a modeling nature. Less than $50 \%$ of the Dutch general practitioners are preceiving their role in such a perspectiven $\theta_{\text {, }}$ appears most clearly from general practitioners' responses to the statement "With my own health behavior I consciously set an example to my patients" agreed to by only $22 \%$. Moreover, drinking, smoking and nutritional habits are seen by most general practitioners as habits in which private and professional life can be successfully separated. Though significant, the differences with community nurses with regard to drinking, smoking and nutrition are far from impressive. Because of the primarily pedagogical nature of teachers' professional performance, it is no more than logical that this profession is the first to recognize their eventual exemplary role. In chapter 9 the relationship between exemplary role recognition and health behavior will be analyzed in detail.

\subsubsection{Prevlous research}

Starting from the assumption that schoolteachers, community nurses, and general practitioners as part of their professional performance act as health educators at least incidentally, Glover's statement that "the role of health educators as models is often overlooked, but may be most powertul change agent." is somewhat justified for elementary schoolteachers, somewhat more for community nurses, and to an even larger extent for general practitioners (Glover, 1978, p.176).

Earlier reports on exemplary role mainly concerned its conceptualization or even nothing more but the desirability of its performance by a professional group with regard to a health toplc (see chapter 4). The example was considered as a most powerful tool (Glover, 1978; Shangold, 1979), and as a prerequisite to the performance of a number of other professional roles (Lichtenstein \& Danaher, 1978; Rosen \& Ashley, 1978). Broadrange exemplary role behavior was found to be pleaded for community nurses. (Fuths, 
1976; Smith, 1984), and for general practitioners (Doll, 1983). Discussing schoolteachers" potential exemplary role Finn (1981) explicitely states the options: the professional can discuss personal health behavior honestly and openly, partly or completely conceal it, or even act purposely as a negative model. Notwithstanding the professional differences, this applies to the educational momentum in all three professional groups. Particularly with regard to smoking, large proportions of teachers, community nurses as well as general practitioners were found to recognize their exemplary role (Adriaanse \& Van Reek, 1986; Adriaanse, Van Reek \& Evers, 1986; Adriaanse, Van Reek \& Van Zutphen, 1987). Although the exemplary role of schoolteachers with regard to smoking was stressed already in the beginning of the century in this country (Van Proosdij, 1957), its limitations should not be overlooked: a considerable proportion of the schoolchildren reported not to know whether their teacher smoked or not (Kannas, Aaroe, Gillies et al., 1985).

Only consonant key health professionals can be effective teachers, posits Shangold (1979), denying the validity of Mettlin's conception of a negative model (Hochbaum, 1980; Mettlin, 1976).

Exemplary role of physicians was pleaded for with regard to drinking, smoking, physical activity, drug use, broad range measurement of exemplary role measurement is not practised, however. Ratings of what are the most pressing health promotion items in the eyes of the professionals are found more often (Wells et al., 1984) than the assessment of these behaviors among key health professionals and the evaluation of their impact on the public.

Among Dutch key health professionals considerable proportions perceive a broadly conceptualized exemplary role. There were no comparable data reported previously in the Netherlands. It is strange, however, to observe that general practitioners as the major health information resource persons do perceive the exemplary role to such a modest extent, while general practitioners abroad were the most verbal in advocating this role for their profession.

Exemplary role recognition regarding smoking could be compared directly because it has been researched in a range of countries. Exemplary role recognition pertaining to tobacco consumption specifically was lower among Dutch general practitioners than among their colleagues in most countries; it was higher among Dutch schoolteachers than abroad. This certainly relates to the substantial smoking prevalences found among Dutch key health professionals. In addition to that, these professional groups are subject to tobacco promotion by the well organized industry, to peer pressure, emancipation of females, and to secularization as any other individual in the population at large. To a certain extent their profession brings about more work stress, for females a duality of roles at work and at home, a professional subculture which might be inducive to smoking and to diminishing the perception of an exemplary role. Moreover, in the Netherlands, the majority of non-smokers is not yet aware of the fact that they constflute a majority. The change of attitudes towards smoking is rather slow in the Netherlands, certainly compared to the USA. England and the Scandinavian countries. Notwithstanding these circumstances, the key health professionals have in depth knowledge and experience with health problems related to smoking. They often are in a unique position of trust visa-vis their patients and pupils. It can only be concluded here that this knowledge, 
experience and trust do not result in a behavioral code accepted in the profession: on the contrary, a divergence of opinions on the exemplary role has been observed among Dutch key health professionals.

Professional claims and/or exhortations to recognize an exemplary role and live up to it were registered almost exclusively abroad, as was observed already. This would suggest that the sociocultural dynamics have had a different impact on health professionals in countries like England, Canada, Sweden and the USA than in the Netherlands. In these countries health consciousness seems to have risen to a higher level among health professionals. Although it is clear the data presented here do not allow strict international comparisons, related work in the area of health professionals' smoking habits, indeed suggest very limited attention for this major preventable risk factor in the Dutch professional literature (e.g. Dekker, 1982). This judgement cannot be generalized to other areas of the health domain without further research.

\subsection{Conclusions}

1. The power of the example in eliciting and channeling behavior may have been well documented (Bandura, 1977), the recognition of this phenomenon among schoolteachers and community nurses in the Netheriands is limited, and notably low among general practitioners.

2. There are no broad-spectrum exemplary role recognition instruments used in previous research. The six-item EXR-instrument presented in this chapter is a useful instrument to measure the recognition of the exemplary role.

3. Comparison with regard to exemplary role fulfilment concerning smoking confirm that recognition of this role, especially among general practitioners, is low. But also for community nurses it appears that in the Netherlands exemplary role recognition is lower than among their colleagues in the Anglosaxon and Scandinavian world. Among Dutch schoolteachers exemplary role recognition with regard to smoking appeared to be higher than among their colleagues abroad.

\subsection{Summary}

A comprehensive instrument to measure recognition of the exemplary role of key health professionals towards their clients is presented. The EXR-scale consists of items concerning smoking, drinking, nutrition and lifestyle (alpha $=.65$ ). Schoolteachers perceived an exemplary role to the largest extent, followed by community nurses; general practitioners were lowest on EXR. Differences and commonalities in the nature of the encounter between professional and patient or pupil are discussed, in as far as these might account for differing EXRs. Compared with earlier research into EXR concerning smoking only, Dutch schoolteachers have higher scores, while general practitioners clearly underscore their colleagues abroad, as do nurses, albeit to a lesser extent. 


\section{References}

Adriaanse, $H_{2}$, Van Reek, J., 1986. Teachers' smoking worldwide: a review of nineteen countries, 1966-1983. International Quarterly Community Health Education, 7, 1, 3-17.

Adriaanse, H., Van Reek, J., Evers, G., 1986. Rookgewoonten van verpleegkundigen wereldwijd. Nederlands-Vlaams Tijdschrift voor Verpleegkunde, 3, 133-145. (Nurses' smoking worldwide).

Adriaanse, H., Van Reek, J., Van Zutphen, W.M., 1987. Arts en roken: de voorbeeldrol van de arts met betrekking tot de algemene bevolking. Medisch Contact 9, 265-267. (Physicians and smoking: the exempllary role of the physician with regard to the population's smoking behavior).

Bandura, A., 1977. Social learning theory. Prentice Hall: Englewood Cliffs.

Dekker, E., 1982. De huisarts en het rookpatroon. In: Proceedings Symposium Foundation Smoking and Health "Trekt de rook op?" (The general practitioner and the smoking pattern). Den Haag.

Doll, R., 1983. Prospects for prevention. British Medical Journal $286,445-453$.

Glover, E.D., 1978. Modeling - a powerful change agent. Journal of School Health, 2, 175-176.

Hochbaum, G.M., 1980. Ethical dilemma's in health education. Health Education, 2, 4-6.

Finn, P. 1981. Hey teachl Do you drink? Journal of School Health, 10, 538-542.

Fuhs, M.F., 1976. Smoking and the heart patient. Nursing Clinics of North America, 2, 361-369.

Kannas, L. Aaroe, L., Gillies, P., Gredler, B., Lecwith, F., Lorant, P., Rimpela, M., Woid, B., 1985. Health behavior in schoolchildren. A WHO cross national survey. University of Jyvalskyla, Department of Health Education.

Lichtenstein, E., Danaher, B.G., 1978. What can the physician do to assist the patient to stop

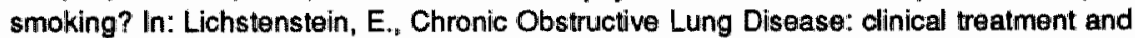
management. Mosby, St.Louis, p. 227-241. Mettlin, C. 1976. Peer and other influences on smoking behavior. Journal of School Health, 9, 529-536.

Rosen, C., Ashley, M.J., 1978. Smoking and the health professional: recognition and performance of roles. Canadian Journal of Public Health, 69, 399-406.

Shangold, M.M., 1979. The health care of physicians do as I say and not as I do. Journal of Medical Education, 56, 668.

Smith, J., 1984. Prevention by example. Nursing Mirror, 13, 17-18.

Van Proosdij, C., 1957. Roken. Dissertation University of Amsterdam. (Smoking).

Wells, K.B., Lewis, C.E., Leake, B., Ware, J.E. 1984. Do physicians practice what they preach? Journal of the American Medical Association, 20, 2846-2848. 


\section{Chapter 9.}

\section{Associations of health behavior with exemplary role recognition and perception of health education}

9.1 Introduction

9.2 Bivariate associations

9.2.1 Health behavior and exemplary role

9.2.2 Health behavior and health education in the actual situation

9.2.3 Health behavior and health education in the desired situation

9.2.4 Exemplary role and health education in the actual situation

9.2.5 Exemplary role and health education in the desired situation

9.2.6 Health education as perceived in the actual and In the desired situation

9.3 Multivariate relationships between health behavior, exemplary role and health education

9.3.1 Correlations, inter- and partial

9.3.2 Determinants of health education perception: regression analysis

9.3.3 Differences between professional groups: discriminant analysis

9.4 Discussion

9.5 Conclusions

9.6 Summary

References 


\subsection{Introduction}

In the chapters 6 through 8 , univariate analyses of health behavior, exemplary role and health education perception in the actual and future work setting were given. In this chapter the focus will be on the rellationship between these variables. Firstly, those key health professionals who behave healthier than their colleagues; do they perceive an exemplany role for themselves to a stronger extent than those who have low scores on the health behavior index (9.2.1)? Secondly, those key health professionals who behave healthier than their colleagues; do they assess aspects of health education as being more important in theil actual work $(9.2 .2)$, and/or are they willing to change the extent to which they devote attention to health education in their future practice? (9.2.3). Thirdly, What is the relationship between the recognition of the exemplary role and importance of health education in current and future practice of school teachers, community nurses and general practitioners in the Netherlands? Do those who recognize clearly an exemplary role for themselves as health professional, indicate different levells of involvement in health education, current or intended? (9.2.4 and 9.2.5). Finally, is there a possibility to express these bivarlate relationships between the core variables of this research in one structure allowing a better comprehension of their interrelatedness (9.2.3)?

These are the questions that will attempt to be answered in this last chapter, first by bivariate then by multivariate analysis, thus finalizing the presentation of the results before entering the general discussion of their significance in the light of what had been reported earlier in the literature (chapters 2 through 4). The scheme below illustrates the organization of the analysis presented in this chapter.

\section{Figure 1. Scheme of analysis}

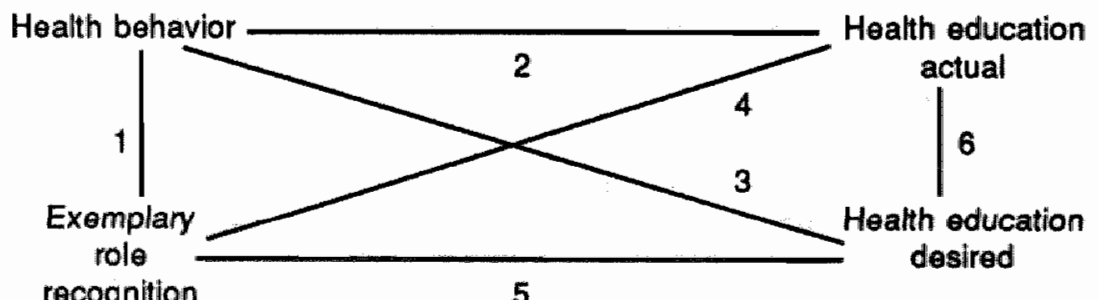

The relationships between health behavior, health education perception in the actual and the desired situation, and exemplary role recoginition are analyzed as follows: firstly in four rounds each core variable under study is dichotomized by its median. Secondly, the professional groups are divided into two groups, per profession and overall participants, on the basis of the one dichotomized variable. Thirdly, average scores per item of the other variables are calculated in the direction as shown in figure 1. Fourthly, the correlational structure of the four core variables is analyzed by means of inter- and partial correlations. Main determinants of the health education perception are located by stepwise multiple regression. Commonalities and differences of the three professional groups with regard to the core variables are established by discriminant analysis. 


\subsection{Bivariate associations between health behavior, exemplary role, and health education}

In the next paragraph the associations between health behavior, exemplary role recognition and the perception of health education in the actual and the desired situation are analyzed pair by pair. For the sake of comparability the median of each variable has been chosen to dichotomize the population as a whole. While at the overall level thus approximately $\mathbf{5 0 \%}$ is in the low and $\mathbf{5 0 \%}$ is in the high group, this is not always the case at the level of separate professional groups. Below the median values of each variable as well as the percentage falling into the lower group is shown: subtracking this percentage from 100 of course shows the percentage falling in the higher group.

Table 9.1 Median values of four core variables per professional group

\begin{tabular}{l|r|r|r|r|}
\hline \multirow{2}{*}{$\begin{array}{l}\text { Group } \\
\text { range }\end{array}$} & $\begin{array}{r}\text { HEA } \\
10-40\end{array}$ & $\begin{array}{r}\text { HED } \\
10-50\end{array}$ & $\begin{array}{r}\text { EXR } \\
0-6\end{array}$ & $\begin{array}{r}\text { HBS } \\
0-10\end{array}$ \\
\cline { 2 - 5 } teachers & $27(34 \%)$ & $33(50 \%)$ & $4(47 \%)$ & $9(61 \%)$ \\
nurses & $26(38 \%)$ & $33(49 \%)$ & $3(60 \%)$ & $10(48 \%)$ \\
physicians & $16(75 \%)$ & $30(68 \%)$ & $2(73 \%)$ & $8(80 \%)$ \\
all professionals & $23(46 \%)$ & $32(48 \%)$ & $3(60 \%)$ & $9(61 \%)$ \\
\hline
\end{tabular}

\subsubsection{Health behavior and the exemplary role}

In this paragraph the relationship between health behavior and the extent to which key health professionals recognize an exemplary role (EXR) is explared. Average EXRscores were calculated per healthy or unhealthy behavior and per professional group, applying to health norms explained earlier in 7.3.3 for the dichotomization of the 12 health behaviors. T-tests were applied to establish differences between high and low HB groups for the professional groups and for all professionals collectively. Finally average health behavior (HBS) scores were calculated per professional group and for all key health professionals. Between schoolteachers behaving healthily and those behaving unhealthily significant differences of average EXR-scores (range 0 to 6 ) appeared to exist with regard to sleep (unhealthily behaving schoolteachers had an average EXFscore of 4.3 versus healthily behaving schoolteachers $3.6\left(t=1.84^{*}\right)$ ) and salety-belt use ( 3.1 versus $3.8\left(t=1.70^{*}\right)$ ). Among community nurses, the only health behavior with regard to which their average EXR-score was significantly higher was snacking sweets (2.4 versus $3.1\left(t=1.99^{*}\right)$ ). Among general practitioners, smokers" average EXR score was nearly $50 \%$ lower than the non-smokers' (1.6 versus $\left.3.1\left(t=4.42^{* *}\right)\right)$. Calculating average EXR-scores over all key health professionals together, those behaving unhealthily with regard to smoking, alcohol and seat-belt use do recognize their exemplary rolle to a lesser extent than those who observe the health norms. When key health professionals are dichotomized on the basis of the HBS-median, signilicantly higher EXR-scores were found in schoolteachers ( 3.3 versus $3.9\left(t=1.91^{*}\right)$ ) and general practitioners 1.9 versus $\left.2.7\left(t=2.21^{*}\right)\right)$, but not in community nurses $(2.6$ versus $3.1(t=1.44))$. Calculated over all key health professionals, exemplary role recognition was clearly higher among these with a healthier self-reported behavior $\left(2.6\right.$ versus $\left.3.3\left(t=3.43^{* * *}\right)\right)$. 
Now let us turn to what these differences and commonalities add up to in terms of proportions of key health professionals by breaking professional groups down by dichotomized HBS and EXR at the same time. In table 9.2 percentages of the professional groups belonging to the consonant sections (those with either low HBS and low EXR or high HBS and high EXR) as well as the dissonant sections (those with either high HBS and low EXR or low HBS and high EXR) are presented.

Table 9.2 Health Behavior and Exemplary Role Recognition, dichotomized by the median (HBS and EXR dichotomized)

\begin{tabular}{l|c|c|c|c|}
\hline Modality & $\begin{array}{c}\text { School } \\
\text { teachers }\end{array}$ & $\begin{array}{c}\text { General } \\
\text { practitioners }\end{array}$ & $\begin{array}{c}\text { Community } \\
\text { Nurses }\end{array}$ & All \\
\cline { 2 - 5 } Consonant & 27 & 12 & 35 & 25 \\
HBS $\uparrow$ EXR $\uparrow$ & 15 & 52 & 26 & 31 \\
HBS $\downarrow$ EXR $\downarrow$ & & & & \\
Dissonant & 9 & 7 & 15 & 10 \\
HBS $\uparrow$ EXR $\downarrow$ & 49 & 29 & 24 & 34 \\
HBS $\downarrow$ EXR $\uparrow$ & 100 & 100 & 100 & 100 \\
& & & & \\
\end{tabular}

Among the general practitioners the consonant pattern is most frequent; however, a majority of $52 \%$ has both a low HBS and EXR. Only general practitioners consequently behave healthily and recognize the exemplary role. Nearly half of the schoolteachers have a double standard: low HBS and high EXR. Among nurses and physicians, this proportion is about half that size. Only $27 \%$ of the schoolteachers is consonant having both high HBS and EXR-scores; the proportion of consonant community nurses is the highest of the three professional groups $(35 \%)$.

\subsubsection{Health behavlor and health education In the actual situation}

Average scores of health education perception in the actual situation (HEA: ranging from 1 (not important) to 4 (very important)) were calculated per competency per professional group, dichotomized on the basis of the HBS median (HBS range is $12,46 \%$ lower scores were in the 4 to 8 range, $54 \%$ of the scores in the 9 to 12 range). Both among schoolteachers and among community nurses, none of the health education competencies appeared to be perceived significantly more important in actual practice, by protessionals with scores below the HBS-median compared to those having scores above the HBS-median.

Among general practitioners those with scores below the HBS-median perceived all health oducation competencies as being less important than those practitioners having scores above the HBS-median, except for planning, which is borderline significant $(t=1.57, p \pi .06)$. Calculating average HEA-scores per competency for all key health professionals, all competencies appear to be perceived as significantly more important in actual practice, with the exception of research. Calculating HEA-sumscores (range 10 to 40), ho significant differences appeared to exist between below- and above the HBSmedian scoring teachers and nurses as did appear for general practitioners (16.0 versus 
$\left.19.5\left(t=2.85^{* *}\right)\right)$. Calculated over all professionals, the significance of the greater importance of health education in their actual work persisted (21.3 versus 23.8 $\left.\left(t=2.69^{* *}\right)\right)$.

In table 9.3 using both dichotomized HBS- and HEA-scores, the percentages of the professionals belonging to the consonant (i.e. either both low or both high HBS- and HEA-scores) and dissonant (i.c. inverse HBS and HEA scores), sections are presented.

\section{Table 9.3 Health Behavior and Health Education Perception in the actual} situation

\begin{tabular}{l|c|c|c|c|}
\hline Modality & $\begin{array}{c}\text { School } \\
\text { teachers }\end{array}$ & $\begin{array}{c}\text { General } \\
\text { practitioners }\end{array}$ & $\begin{array}{c}\text { Community } \\
\text { nurses }\end{array}$ & All \\
\cline { 2 - 5 } Consonant & 24 & 5 & 30 & 20 \\
HBS $\uparrow$ HEA $\uparrow$ & 17 & 61 & 15 & 31 \\
HBS $\downarrow$ HEA $\downarrow$ & 11 & 14 & 19 & 15 \\
Dissonant & 49 & 20 & 35 & 35 \\
HBS $\uparrow$ HEA $\downarrow$ & 100 & 100 & 100 & 100 \\
HBS $\downarrow$ HEA $\uparrow$ & & & & \\
& & &
\end{tabular}

Again among the general practitioners the consonant negative pattern appeared to prevail: $61 \%$ has a HBS- and HEA score below the median, i.e. does not perceive health education as very important in their actual work. Consonant positives, i.e. those having above the median HBS- and HEA-scores add up to only five percent, whereas among community nurses there are four times as many, among teachers nearly five times (i.e. $24 \%$ ). However, dissonance prevails also among teachers and nurses.

\subsubsection{Health behavior and health education in the desired situation}

Average scores of health education perceptions in the desired situation (HED: range 1 (wants to give less attention to specific health education competency) through 3 (equal attention) to 5 (much more attention)) were calculated per competency per professional group, dichotomized on the basis of the HBS-median. Among schoolteachers and general practitioners, virtually no differences existed in the perception of the extent to which these professionals want to devote attention to health education in their future work, between the above and below-the-HBS median groups. Among community nurses the only exception was the "research" competency. Nurses having a score above the HBS-median considered research more desirable than did their lower scoring colleagues ( 2.7 versus $\left.3.2\left(t=2.17^{*}\right)\right)$. Calculated over all key health professionals, significant difference appeared to exist with regard to counseling and guidance of others (2.9 versus $3.1\left(t=1.76^{*}\right)$, borderline significant difference with regard to implementation (3.3 versus $3.5(t=1.54, p=.06))$. Above and below the HBS median scoring professionals appeared to perceive no significant difference in health education in their future work, when the HED-sumscore is used (range 10-50). 
In table 9.4, using both dichotomized HBS- and HED-scores, the percentages of the professionals belonging to the consonant (i.e. either both low HBS and HED, or both high HBS and HED) or dissonant sections are presented.

Table 9.4. Health behavior by health education perception in the desired situation

\begin{tabular}{l|c|c|c|c|}
\hline Modality & $\begin{array}{c}\text { School } \\
\text { teachers }\end{array}$ & $\begin{array}{c}\text { General } \\
\text { practitioners }\end{array}$ & $\begin{array}{c}\text { Community } \\
\text { nurses }\end{array}$ & All \\
Consonant & 19 & 6 & 27 & 18 \\
HBS $\uparrow$ HED $\uparrow$ & 30 & 46 & 19 & 32 \\
HBS $\downarrow$ HED $\downarrow$ & & & & \\
Dissonant & 15 & 13 & 22 & 17 \\
HBS $\uparrow$ HED $\downarrow$ & 37 & 35 & 31 & 34 \\
HBS $\downarrow$ HED $\uparrow$ & 100 & 100 & 100 & 100 \\
\hline
\end{tabular}

Among the professional groups the division over consonant and dissonant is approximately half/halt with the exception of the general practitioners' group. Among general practitioners the consonant negatives largely outnumber the consonant positives. Both among teachers and nurses about three times as many were found. One third of both teachers and nurses had both low HBS and HED-scores.

\subsubsection{Exemplary role recognition and health education In the actual sltuation}

Average HEA-scores were calculated per competency per professional group. dichotomized on the basis of the EXR-median (EXR-range: 0 to 6 , median $3 ; 60 \%$ of key health professionals had below or up to the median scores; $40 \%$ from 4 to 6 ). Among schoolteachers, those having above-the-median EXR-scores, perceived 'creating conditions' (2.0 versus $\left.2.9\left(t=1.82^{*}\right)\right)$, "planning" (2.2 versus $\left.2.6\left(t=1.64^{*}\right)\right)$ and "implementation" (2.7 versus $\left.3.1\left(t=1.96^{*}\right)\right)$ as being more important in their actual practice than did those having below the median EXR-scores. In the nurses, no differences with regard to any competency appeared to exist between the two groups. Among general practitioners, by those with EXR-scores above-the-median, all health education competencies were considered to be more important than by those recognizing the exemplary role to a lesser extent, with the exception of planning and research. Calculated over all key health professionals, significant differences appeared to exist for all health education competencies except for research. Summating all health education competencies (HEA: range 10-40), this difference subsists for general practitioners ( 16.3 versus $\left.19.4\left(t=2.56^{* *}\right)\right)$ but not in schoolteachers and community nurses.

In table 9.5, using both dichotomized EXR-and HEA-scores, the percentages of professionals belonging to the consonant (i.e. either both high EXR- and high HEAscores or both low EXR- and HEA-scores) and the dissonant sections are presented. 
Table 9.5. Exemplary role recognition and heaith education in the actual situation

\begin{tabular}{l|c|c|c|c|}
\hline Modality & $\begin{array}{c}\text { School } \\
\text { teachers }\end{array}$ & $\begin{array}{c}\text { General } \\
\text { practitioners }\end{array}$ & $\begin{array}{c}\text { Community } \\
\text { nurses }\end{array}$ & All \\
\cline { 2 - 6 } Consonant & 56 & 14 & 39 & 36 \\
EXR $\uparrow$ HEA $\uparrow$ & 8 & 47 & 15 & 24 \\
EXR $\downarrow$ HEA $\downarrow$ & & & & \\
Dissonant & 20 & 28 & 19 & 22 \\
EXR $\uparrow$ HEA $\downarrow$ & 17 & 11 & 26 & 18 \\
EXR $\downarrow$ HEA $\uparrow$ & 100 & 100 & 100 & 100 \\
& & &
\end{tabular}

There are somewhat more consonant than dissonant key health professionals. Again, while consonant positives outnumber consonant negatives among teachers and nurses largely, consonant negatives prevail among general practitioners.

\subsubsection{Exemplary role and health education in the desired situation}

Average scores for health education perception in the desired situation (HED) were calculated per competency (range 1-5) per professional group, dichotomized on the basis of their EXR-median (EXR range 0-6, median 3). Teachers with EXR-scores above the median perceived "creating conditions" ( 3.1 versus 3.4 (t=2.03")), "assessment" $(2.9$

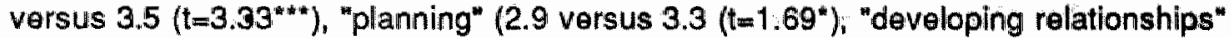
( 2.9 versus $3.3\left(\mathrm{t}=1.73^{*}\right)$ and "implementations" ( 3.3 versus $3.8\left(\mathrm{t}=2.75^{*}\right)$ ) as being more important in their future work than those with lower EXR.

Among general practitioners commonalities were prevalent with different exemplary role recognition. Only the extent to which general practitioners wished to pay attention to planning for health education was perceived differently $\left(2.7\right.$ versus $\left.3.0\left(t=1.84^{*}\right)\right)$. Among the nurses group, again research was the only competency perceived as being more important by those nurses having EXR-scores above the median ( 2.8 versus 3.2 $\left.\left(t=2.09^{*}\right)\right)$. Calculated over all professionals, all health education competencles were considered to be more important for their future work by those with above the median EXR-scores than by those with lower scores, with the exception of "planning" and "counselling and guidance for others".

In table 9.6, using both dichotomized EXR- and HED-scores, the percentages of professionals belonging to the consonant, i.e. either both low or both high EXA- and HED-scores, and dissionant sections are presented. 
Table 9.6. Exemplary role recognition by health education in the desired siluation

\begin{tabular}{l|c|c|c|c|}
\hline Modality & $\begin{array}{c}\text { School } \\
\text { teachers }\end{array}$ & $\begin{array}{c}\text { General } \\
\text { practitioners }\end{array}$ & $\begin{array}{c}\text { Community } \\
\text { nurses }\end{array}$ & All \\
\cline { 2 - 5 } Consonant & 46 & 20 & 35 & 34 \\
EXR $\uparrow$ HED $\uparrow$ & 14 & 38 & 18 & 23 \\
EXR $\downarrow$ HED $\downarrow$ & & & & \\
Dissonant & 31 & 20 & 24 & 25 \\
EXR $\uparrow$ HED $\downarrow$ & 10 & 21 & 24 & 18 \\
EXR $\downarrow$ HED $\uparrow$ & 100 & 100 & 100 & 100 \\
\hline
\end{tabular}

The same distribution pattern as observed earlier was found: among teachers and nurses the consonant positives prevail, while among general practitioners the consonant negatives dominate. A sizeable number of teachers $(31 \%)$ adheres to exemplary role fulfilment but has a below the median level of aspirations for health education in their future practice.

\subsubsection{Health education as percelved In the actual and desired situation}

Average scores for health education in the actual (HEA) and in the desired (HED) situation were calculated per competency and per professional group, dichotomized on the basis of the HEA sumscore-median (range of HEA is from 10 to $40 ; 46 \%$ of the scores is under median $23,54 \%$ ranges from 24 to 40 ). Among teachers as well as among nurses significant differences existed between those prolessionals having below the HEA-median scores and those having above the HEA-median scores. Without any exception the latter group wanted to devote more attention to health education in their future work. Among teachers all differences were highly significant i.e. p<.001 and tvalues varying between 3.89 and 6.99. Among general practitioners there were no differences between those scoring below and above the HEA-median with regard to any health education competency to be applied in their future work with the exception of "coordination" (2.6 versus $3.2(t=2.34))$. Calculated over all key health professionals, significant differences were found with regard to all competencies.

In table 9.7 using both dichotomized HEA- and HED-sumscores, the percentages of professionals belonging to the consonant (i.e. either both high or both low HEA- and HED-scores) and dissonant sections are presented). 
Chapter 9. Associations...

Table 9.7 Health education in the actual situation by health education in the desired situation

\begin{tabular}{l|c|c|c|c|}
\hline Modality & $\begin{array}{r}\text { School } \\
\text { 1eachers }\end{array}$ & $\begin{array}{c}\text { General } \\
\text { practitioners }\end{array}$ & $\begin{array}{c}\text { Community } \\
\text { nurses }\end{array}$ & All \\
\cline { 2 - 5 } Consonant & 52 & 15 & 45 & 37 \\
HEA $\uparrow$ HED $\uparrow$ & 24 & 48 & 20 & 31 \\
Dissonant & & & & \\
HEA $\uparrow$ HED $\downarrow$ & 20 & 11 & 21 & 17 \\
HEA $\downarrow$ HED $\uparrow$ & 4 & 26 & 13 & 15 \\
& 100 & 100 & 100 & 100 \\
\hline
\end{tabular}

Among the three professional groups approximately tho thirds were coneonant. Among general practitioners, once again consonant negatives prevailed. The latter outnumbered the 15 percent consonant positives by a factor three. Among schoolteachers and community nurses, on the contrary, more than twice as many professionals were to be positively consonant. Calculated over all professionals those who perceive health education in their actual work as being of major importance express the desire to give more attention to health education in their future work than those having below the median HEA-scores $\left(33.4\right.$ versus $\left.28.2\left(t=6.51^{* * *}\right)\right)$. This was true for schoolteachers ( 34.1 versus $25.8\left(t=5.6^{* * *}\right)$ ), and for community nurses $\left(33.8\right.$ versus $\left.28.4\left(t=4.0^{* * *}\right)\right)$, but not for general practitioners (30.2 versus 29.0 ).

\subsubsection{Correlational structure: Inter- and partial correlations}

In order to further explore the associations between the four core variables (see fig. 1), intercorrelations were calculated, as well as partial correlations between pairs, stepwise controlling for the two remaining variables, In figure 1, the correlations are shown for the schoolteacher group. The second figure within parentheses gives the remaining correlation when the association is controllad for the other two variables. Only when stepwise partialling out of variables changes the remaining correlation significantly. separate influences will be mentioned in the text.

Figure 2. Association between health behavior, exemplary role and health education, schoolteachers ( $N=92)$ (Pearson's + partial correlations)

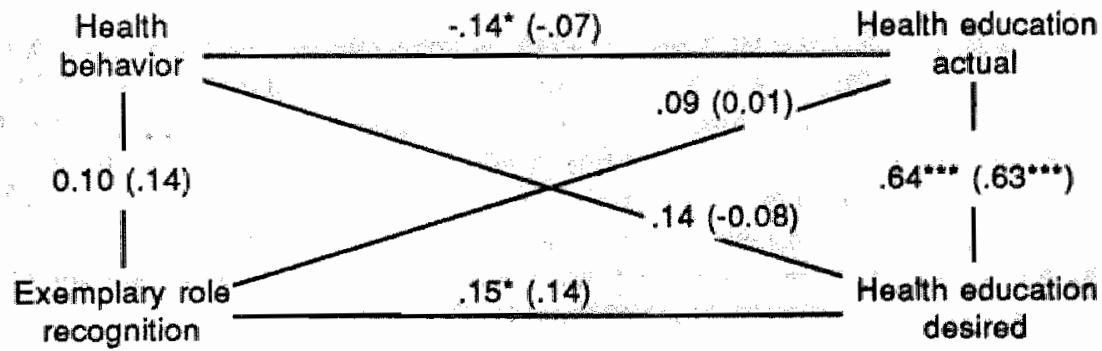


Among schoolteachers a strong and persisting association appeared to exist between HEA and HED. Apart from a borderline significant association of EXR with HED, no other associations were found. Controlling for health behavior lifts the EXR/HED-correlation to $.18^{*}$, but additional control for HEA brings it down to .14,

In figure 3 ; inter- and partial correlations for the nurses group are shown.

Figure 3. Association between health behavior, exemplary role and health education, community nurses ( $N=92$ ) (Pearson's + partial correlations)

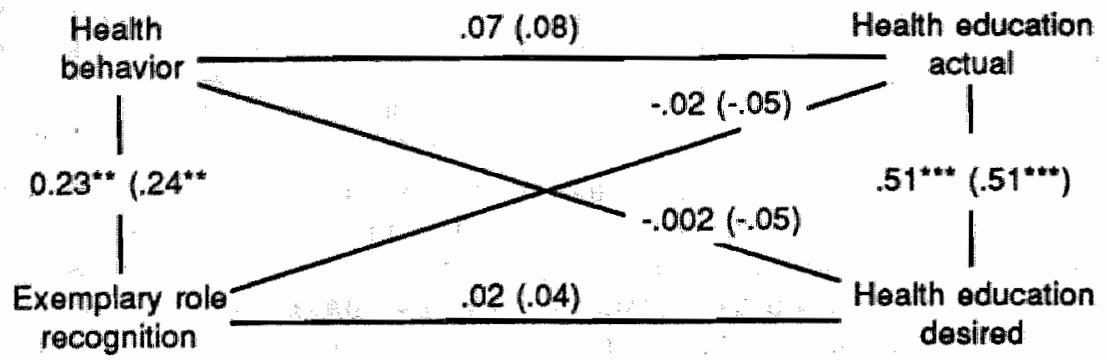

Among community nurses also, there appeared to exist a substantial and lasting relationship between HEA and HED $\left(.51^{* * *}\right)$. Furthermore ${ }_{\text {" }}$ a positive association of HBS with EXR was found, which remained when controlled for the two health education perception variables HEA and HED.

In figure 4 the inter-and partial correlations for the general practitioner group are shown.

Figure 4. Association between health behavior, exemplary role and health education, general practitioners ( $N=95)$ (Pearson's + partial correlations)

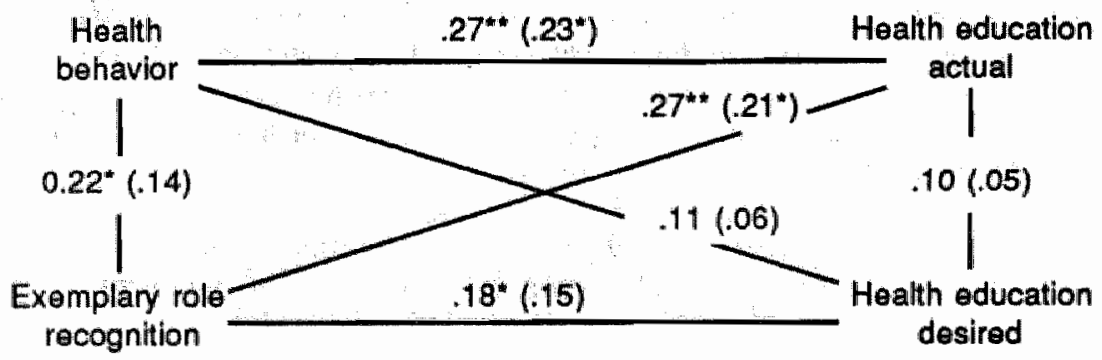

Among general practitioners, HBS appeared to be positively associated with HEA and with EXR. While the HBS/HEA correlation subsisted after control for EXR and HED, the HBS/EXR correlation dropped just below the level of significance from .22* to 14 . This is due to the remarkable unrelatedness of health education in the actual and the desired situation found among general practitioners. The correlation between EXR and HED $\left(.18^{*}\right)$ also dipped below the level of significance when controlled for HBS and HEA. Among general practitioners a positive association was found between EXR and HEA, persisting at .21* when controlled for HBS and HED. 
In an attempt to explore the generics across all three key health professions, inter- and partial correlations were calculated over all respondents.

Figure 5. Association between health behavior, exemplary role and health education, all professionals ( $N=284$ ) (Pearson's correlation, added partial correlations, controlling for the two remaining core variables)

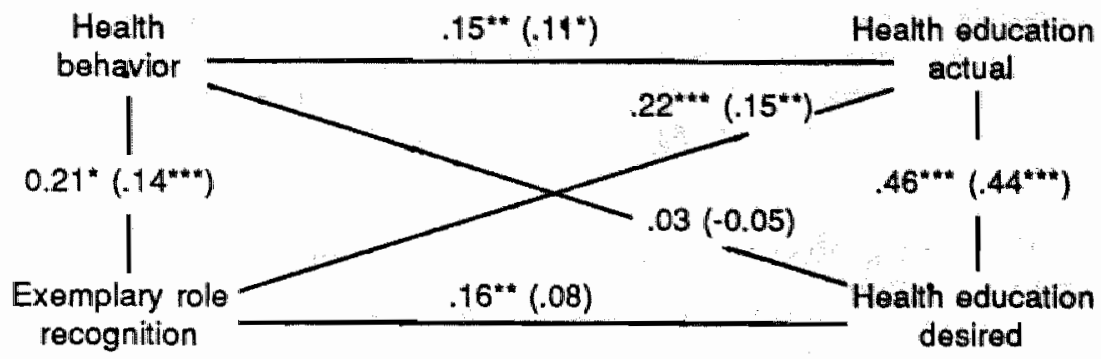

In figure 5 it can be seen that over all HEA was firmly and positively associated with HED; that modest but persisting relations existed between HBS and HEA, HBS and EXR. EXR and HEA. Nowhere any association between HBS and HED emerged. The relationship between EXR and HED subsisted after control for HBS $\left(.16^{*}\right)$ but disappeared after additional control for HEA (.08).

\subsubsection{Determinants of health education perception: regresslon analysls}

Will it be possible to predict the extent to which key health professionals want to give attention to health education in their future practice? As our data concerning health behavior and health educational aspects of professionat performance were collected in a single survey, no causal relationships can be established. At best, the associations found can help to generate hypotheses about causal relationships, and eventually predict future health educational involvement. These restrictions should be kept in mind, while interpreting the results of the following analyses. More strictly than partial correlation, multiple linear regression allows to weigh the influence of more than one variable on the dependent variable. In table 9.8 the results of stepwise multiple regression of HBS and EXR are presented.

Table 9.8. Determinants of health education in the actual situation

\begin{tabular}{ll|c|c|c|c|}
\hline & \multicolumn{1}{c}{ Beta } & $P$ & Multiple Corr & $F$ \\
School teachers & None of the variables reached $p=.05$ \\
Community nurses & None of the variables reached $p=.05$ \\
General practitioners & 1 HBS & .23 & .005 & .28 & $8.25^{* *}$ \\
& $2 \mathrm{EXR}$ & .22 & .028 & .34 & $6.77^{* *}$ \\
All professionals & $1 \mathrm{EXR}$ & .22 & .0001 & .22 & $14.90^{* * *}$ \\
& $2 \mathrm{HBS}$ & .10 & .07 & - & - \\
\hline
\end{tabular}


Within the teachers and the nurses group no variables reached the requested level of significance $(p-0.05)$. Within the general practitioners both HBS and EXR appeared to be valid predictors for HEA (total multiple correllation .34). Calculating the same regression over all professionals, only EXR subsisted as a valid predictor of HEA. HBS dropped out with borderline significance. The results of stepwise regression of EXR, HBS and HEA on HED did not produce any new insights.

Among teachers and nurses HEA appeared to be the only valid predictor for HED, explaining a substantial amount of its variance in both cases. Among general practitioners no valid predictor for HED could be found. Calculating the same regression over all professionals HEA subsisted as single predictor for HED (correlation .46; $\left.F=76.43^{* * *}\right)$..

\subsubsection{Differences between the three professional groups: discriminant analysis}

In order to describe the differences between the three professional groups systematically and coherently, a discriminant analysis was carried out. Discriminant analysis allows to calculate a weighed sum of the original predictor variables providing the optimal function to discriminate between groups. Introduction EXR, HBS, HEA and HED in the discriminant analysis procedure gave the following results. The mean values per professional group on the two discriminant functions were for (F1/F2) .54/-.30) for teachers, for physicians $-.84 / .07$, and for nurses $.28 / .35$.

Table 9.9 Discriminant analysis: structure matrix

\begin{tabular}{l|c|ccc|}
\hline Varlables & Wilks' Lambda & \multicolumn{3}{|c|}{ Standard canonical discriminant function } \\
& & function & $F 1$ & $F 2$ \\
\hline EXR & .90 & & .40 & -.65 \\
HBS & .93 & .18 & .88 \\
HEA & .78 & .88 & .01 \\
HED & .97 & .12 & .23 \\
\hline
\end{tabular}

All four variables had highly significant Wilks' Lambda values. The first discriminant function (Eigen value of .36; Wilks" Lambda $=68$ ) explained $83 \%$ of the variance; the second function (Eigen-value .08; Wilks' Lambda .93)) explained another $17 \%$ of the variance. The Chi squared Wilks' Lambda of the first function was 107.1 (df $=8 ; p=.0001$ ), of the second function $20.3(\mathrm{~d}=3 ; \mathrm{p}=0.001)$.

The correlations with the first function produce an interpretable picture. The best function to differentiate between schoolteachers, community nurses and general practitioners then are: (F1) $D=.88 \mathrm{HEA}+.40 \mathrm{EXR}+-.12 \mathrm{HED}+.18 \mathrm{HBS}$. (F2) $D=.01 \mathrm{HEA}-.15 \mathrm{EXR}$ +.23 HED + .88 HBS.

The first function suggests that HEA is the predominant discriminating variable between the three professional groups, secondly EXR and lastly HBS. The second function suggests that as a next best explanation of the differences the contradiction between EXR and HBS plays a role (-.65 EXR $+.88 \mathrm{HBS})$, while HEA and HED in this function have a low coefficient. 
Chapter 9. Associations...

In table 9.10 the correlations between the four variables and the two discriminant functions are presented.

Table 9.10 Pooled within groups correlations between discriminating variables and canonical discriminant function

\begin{tabular}{|c|c|c|}
\hline & $F 1$ & $F 2$ \\
\hline HEA & .88 & .07 \\
HER & .51 & -.46 \\
HBS & .30 & .14 \\
\hline
\end{tabular}

The interpretation of the second function does seem to fit earlier reported dissonance. However, given the fact that $83 \%$ of the variance is explained by the first function, the second function is considered as being of crucial but only additional value for the explanation of differences betweon the professional groups.

The individual discriminant scares were used to calculate average scores per group. These were plotted graphically on the two axes constituted by the two discriminant functions (fig. 6).

Figure 6. Discriminant analysis

ST $=$ school teacher $\mathrm{CN}=\mathrm{comm}$. nurses GP=general practitioners

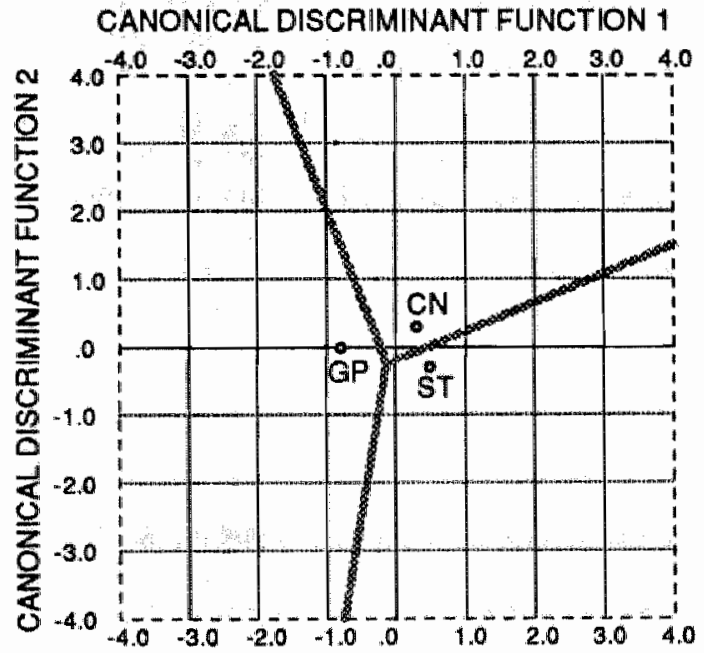

As can be seen, the group centroid for community nurses is on the positive side with

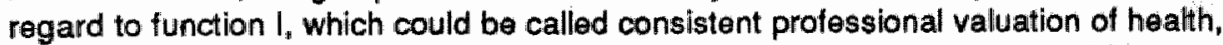
while schoolteachers are on its negative side and physicians show a zero. With regard to the second function, characterized by low EXR and dominated by HBS, both nurses and teachers are on the positive side, whereas doctors are clearly negative. 


\subsection{Discussion}

When these results are compared with the trequency distributions of $H E A, H E D, H B S$ and EXR, as reported in chapters 6 through 8 , it can be seen that the results of the discriminant analysis are in line with the significant differences found with regard to health education in the actual situation (HEA) between the three professional groups. The results of the discriminant analysis at the same time reflect the lack of discriminating power of health education in the desired situation (HED), reported in chapter 6 . With regard to health behavior the first function emerging from the discriminant analysis is in line with the existence of the consonant groups. The second discriminant function confirms the existence of sizeable dissonant groups reporting either low HBS and high EXR, or high $\mathrm{HBS}$ and low EXR (respectively $34 \%$ and $10 \%$, see table 9.2 .

\subsubsection{Health behavior and exemplary role}

From the correlations between HBS and EXR it was concluded that there was no significant relationship between these variables in teachers and general practitioners. This is remarkable because one would expect key health professionals for instance to be non-smokers and to perceive an exemplary role to a reasonable extent. This is not the case for teachers" health behavior, except for safety belt use (frequent users have a $13 \%$ higher average EXR-score). For nurses HBS and EXR were related positively $\left(.24^{*}\right.$ after control for HEA and HED). At health practices level no significantly differing EXR-scores were found except for the averages for frequent and non-frequent sweets snacking (frequent consumers have a $30 \%$ higher average EXR-score). For general practitioners, health behavior and exemplary role recognition were related positively $\left(r=.22^{*}\right)$, but not atter control for HEA and HED $(r=14)$. The original correlation was mainly due to the smoking item in HBS (EXR-average was $93 \%$ higher among non-smokers than among smokers) and to safety belt use ( $44 \%$ higher among frequent users). Moderate alcohol users' and abstainers" EXR score was $14 \%$ higher than immoderate drinkers, calculated over all key health professionals together. Smoking, alcohol consumption and safety belt use are quite visible health practices. Related risks are well known and subject to public debate. These habits are targets for large educational campaigns. It is then consistent to see a relation between tobacco-, alcohol- and seatbelt use, and the exemplary role. As was concluded from chapters 3 and 7 , health behavior is a complex hierarchically structured behavior (Pill \& Stott, 1985). Smoking and alcohol were found to be the third and second most difficult behaviors in that hierarchy, seatbelt use was midrange (chapter 7). It can be concluded that visibility is more important in relation to exemplary role perception than is relative difficulty. The consonant pattern , prevailing among general practitioners, is due to the majority of physicians having both low EXR- and low: HBS-scores (52\%). Among teachers about the same proportion (49\%) has a low EXRand a high HBS-score.

\subsubsection{Health behavior and health education perception in the actual situation}

Among general practitioners; the relation between health behavior and health education in current practice was modestly present $\left(23^{\circ}\right)$. Among teachers and nurses this rellation was not found. For physicians, the large proportion of consonant negatives reinforced 
the bad and honest image of doctors' outlook on health. About half of the schoolteachers $(49 \%)$ behave in a relatively unhealthy way but do perceive health education as being important in their current teaching practice. This situation indicates a double standard mentality, referred to earlier by Shangold with regard to physicians (Shangold, 1979). The proportion of double standard i,e. dissonant physicians, however, is the smallest among the three professional groups studied here.

Physicians with a relatively healthier behavior do perceive all health education competencies as being more important than those who bohave in less healthy ways. This consistent pattern was absent among teachers and nurses. The only exception was implementation of health education, which was more important for nurses with higher health behavior scores. For teachers, this remarkable inconsistency might be related to the late introduction of health education in the Dutch elementary school system (only in 1985). Our data were collected in 1983 so most teachers yet had not had any formall experience with health education teaching. For community nurses, the consistent pattern is limited to the implementation competency. Implementation of health education being one of their major tasks, this significant difference of HEA score is quite important for community nursing practice. It suggests that nurses with a less healthy lifestyle, practice less health education.

\subsubsection{Health behavior and health education In the desired situation}

A relationship of health behavior with health education in the desired situation could not be detected. HBS was dropped from regression equations predicting HED. It did not produce any significant correlation in any professional group with HED. Lastly. professionals with above- and below the median HBS-scores did not differ with regard to any competency. The only exception to this was nurses willingness to increase efforts in the research area. The intention to devote more attention to health education in future work seemed unrelated to self reported health behavior (HBS). It is remarkable that approximately one third of all three professional groups intended to give more attention to health education while their HBS score was below the median. Whereas a modest correlation subsisted after control, for the relation of HBS with HEA $\left(.11^{*}\right)$, there was none for the association of HBS with HED. It can be speculated that intentions for future health education efforts are mainly determined by other than health behavioral considerations, $\theta . \mathrm{g}$. the existence of organizational or financial constraints or incentives.

\subsubsection{Exemplary role and health education in the actual situation}

Exemplary role recognition calculated over all key health professionals is associated with HEA $\left(.22^{*}\right.$, after control $\left..15^{*}\right)$. This is mainly due to the general practitioners $\left(r-27^{* *}, 21^{*}\right.$ after control). It is remarkable that for teachers and nurses no relationship between EXR and HEA could be found. The importance of the pedagogical aspect, especially in the teaching profession triggers inverse expectations. It is remarkable too that among general practitioners the consistency between EXR and HEA is predominantly due to low appreciation of both. However, this is congruent with earlier findings concerning Dutch general practitioners with regard to their perception of an exemplary role and their smoking behavior (Dekker, 1982). This dissonance has been described somewhat cynically as "the successfull compartimentalization of professional and private lile" (COe \& Brehm, 1972). 


\subsubsection{Exemplary role and health education In the desired situation}

As is to be expected exemplary role recognition at first sight is positively associated with HED in teachers, physicians and overall key health professionals. After control for HBS and HEA the correlations disappear below the level of significance. It is not clear why EXR should not bear on the intention to give more or less attention to health education in future work, but it does not.

\subsubsection{Health education In the actual and desired situation}

From regression analysis we saw that HEA was the best predictor for HED. Among teachers the correlation was .64 among nurses .51; in general practitioners however, no such relation was found. The patterns of growing involvement in health education prevalent among teachers and nurses is exceptional among physicians. A sizeable minority of $26 \%$ of the general practitioners had the intention to increase attention for health education in their future practice although health education is not important in their actual work. This suggests that especially among general practitioners there is a need for development and training in the area of health education.

\subsection{Conclusions}

1. Teachers and general practitioners with above the median HBS-scores do perceive an exemplary role to a larger extent than do their colleagues with below the median HBSscores, while community nurses do not. For three health practices (use of tobacco, alcohol and seat belt), significantly differing average EXR-scores were found.

2. A sizeable group of physicians has a rather unhealthy lifestyle and does not want to be involved in health education. A sizeable group of teachers has a rather unhealthy lifestyle and reports high levels of recognition of the exemplary role and involvement in health education.

3. General practitioners with unhealthy lifestyles report health education to be less or not important in their practice. For teachers and nurses there is no clear relationship of health behavior and health education in current practice.

4. Health education in the desired situation is mainly determined by the actual involwement in health education. This is true for leachers and nurses, but not for general practitioners.

5. Differences between the three professional groups are determined in the first place by health education in the actual situation, secondly by exemplary role recognition and thirdly by both health behavior.

6. Dissonance and consonance with regard to protessional perception of health education and personal health behavior are almost evenly distributed among schoolteachers and community nurses: negative consonance prevails among general practitioners. 


\subsection{Summary}

In this chapter the relationships between health behavior (HBS), exemplary role recognition (EXR) and health education perception in the actual (HEA) and health education in the desired situation (HED) are analyzed. Firstly, bivariate relationships were analyzed by dichotomizing the core variables at their median, and calculating averages for the dependent variables, for the "high" and "low" groups. Then, the care variables were dichotomized in pairs, to establish the proportions of consonants and dissonants of key health professionals reporting healthy behavior, schoolteachers and general practitioners recognized the exemplary role to a larger extent than those reporting relatively unhealthy behavior. For community nurses no differences were found. Among schoolteachers dissonance with low HBS and high EXR were the largest group, among general practitioners, consonants with both low HBS and low EXR even constituted a majority. Among community nurses consonants with both high HBS and EXR were larger than any other subgroup.

Of key health professionals reporting healthy behavior general practitioners perceived health education in their actual work as more important than those reporting relatively unhealthy behavior: this difference was not found in teachers and community nurses. Among general practitioners, the largest group were the consonant who had both low HBS and low HEA; in schoolteachers again, the dissonants with low HBS and high EXR. In community nurses, dissonants with low HBS and high EXR, as well as consonants with high HBS and high HEA comprised about one third.

Key health professionals reporting healthy behavior did not differ in the perception of health education in their future work from those reporting relatively unhealthy behavior. Of key health professionals recognizing the exemplary role to a larger extent, general practitioners perceived health education as more important than those physicians who do recognize this rolle to a limited extent only: community nurses and schoolteachers did not differ in this regard.

In schoolteachers and community nurses the consonant groups with both high EXF and HEA were the largest one: in general practitioners the consonant with low EXR and HEA was the largest subgroup. Also, in teachers and nurses, the consonant groups with both high EXR and HED were largest within their profession. In general practitioners the consonant with both low EXR and HED, was the largest group.

Of key health professionals perceiving health education as relatively important, schoolteachers and community nurses wanted to give more attention to health education in their future work; this difference was not found among general practitioners. In schoolteachers and community nurses, the consonant groups with both high HEA and HED were largest. In general practitioners the consonant group was with both low HEA and HED; second largest was a substantial dissonant group of one quarter willing to increase attention for health education. Calculation of correlations confirmed most of the associations between HBS and HEA, EXR; between HEA and HED.

Analysis of the determinants of the between-groups differences showed that the first discriminant function, explaining $83 \%$ of the variance, consisted of (1) HEA, (2) EXR and (3) HBS. It is concluded that contradictions in professional perception of health education and personal health behavior are about as widely spread as congruence in schoolteachers and community nurses. In general general practitioners congruence prevails, mostly in a negative sense, however. 


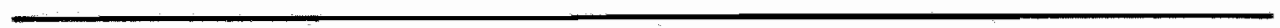




\section{Chapter 10.}

\section{General discussion; concluding remarks}

10.1 Brief review of the intended study

10.2 Realization of the project

10.3 Results

10.4 Limitations

10.5 Implications of the study for:

10.5.1 methods

10.5.2 theory

10.5.3 pollicy

10.5.4 professional preparation

10.6 Further research 


\subsection{Brief review of the intended study}

The origins of the research reported here can be found in the assignment by the Foundation Netherland OKer, a coalition of organizations in the field of prevention and health care, to the University of Limburg, to draw a picture of health in Holland. The intention of the study was to provide a large picture of health in the Netherlands in the early 1980's, delineating experiences, conceptions and behaviors concerning health. Within that framework of this so-called Health Panel Study, this researcher's task was to focus on the key health professional's outlook on health in relation to health conceptions and -behaviors found among the population at large. The Health Panel Study was designed as a longitudinal project: future replications and extensions hopefully will allow to analyse secular trends in thinking and acting on health.

Elementary school teachers, community nurses and general practitioners were considered to play important roles at the most basic level of daily reproduction of health through fulfilment of basic human needs, for instance nutrition, sleep, hygiene and primary health care. These key health professionals were felt to be important groups because they are highly visible in society, they are experts in their fields, they are responsible for caring for large groups of the population in all phases of life.

\subsection{Realization of the project}

The preparations for the second phase of the project, part of which has been reported here, started in 1982. Actually, the research questions the project would focus on, were formulated on the basis of the first broad health survey carried out in 1981. Unlike in this first phase, questionnaires were not identical for the population and for the key health professionals. As it had been decided to collect data not only concerning health conceptions and health behavior, but also concerning professional performance of teachers, nurses and general practitioners, specific questionnaires had to be developed. As comparison of the three professional groups with the population at large was aimed at, nationwide sampling of respondents was applied. To enhance response rates and to better guarantee reliability, personal interviews were conducted at the work site of the key heaith professionals by trained interviewers. The questionnaires were largely developed in the project itself, as few standardized instruments were available. Data collected occurred in the spring of 1983. Analyses and reporting were carried out from 1984 to 1987.

\subsection{Results in a nutshell}

The study has resulted in a wealth of data on health conceptions, -behaviors and health educational aspects of the work of schoolteachers, community nurses and general practitioners. In this thesis, an analysis using the four care variables is presented.

These four core variables were: the perception of health educational aspects in the actual and desired work situation of the three professional groups, their health behavior and their eventual exemplary role. The health educational aspects of the work have been measured by a set of ten (aggregated) competencies. Respondents rated their 
importance in their actual work setting on a four-point scale, and the extent to which a given health professional would want to give less equal or more attention to any health educational competency on a five-point scale. Health behavior was measured by a 12 item Health Behavior Scale (HBS) comprising items concerning coffee-, alcoholl-, tobacco- and sugar consumption, dental hygliene and-check-up frequency, on weight for height, sleep duration, seatbelt use and manual hygiene. Exemplary role recognition (EXR) was measured by a six-item list containing three generall lifestyle statements and three others pertaining to alcohol, drugs and tobacco-use.

As it appeared ${ }^{*}$ the involvement of general practitioners in health education in their actual practice was much less than that of community nurses and elementary schoolteachers. A lack of coherence in health educational efforts by these professional groups showed. Moreover, none of them fulfils or aspires a coordinating role.

Compared with the Dutch population at large $e$ key health professionals more frequently choose healthy alternatives with regard to breakfasting, coffee consumption and dental hygiene. Surprisingly, they are snacking more sweets in between meals than the population at large reports doing. Less community nurses, however, use sugar in their coffee. While considerably fewer schoolteachers and community nurses are current smokers, there are more current smokers in general practitioners than in the male population. While nurses less frequently capitalize on alcohol, schoolteachers and generall practitioners do so more frequently than the population in Holland.

Health behaviors appeared to be less prevalent in general practitioners than in community nurses and schoolteachers, especially non smoking, moderate use of alcohol and seatbelt use. Using a comprehensive Health Behavior Scale to measure health behavior, it appeared that community nurses had the most healthy lifestyle, followed closely by schoolteachers. Exemplary role recognition differed significantly in key health professionals, schoolteachers recognizing an exemplary role to the largest extent, followed by community nurses and finally by general practitioners.

For schoolteachers and community nurses the extent to which one said to practise health education in the actual work setting appeared to be positively related to the extent to which these professions stated their intention to act on health education in their future professional practice; not so, for general practitioners, however.

For schoolteachers and community nurses health behavior was not related to health education, in their current work settling, this was only the case for general practitioners, albeit largely consistently negative. Health behavior appeiared to be related to the extent to which an eventual exemplary role is recognized for general practitioners and community nurses, but not for schoolteachers. Current health behavior appeared to be unrelated to the extent to which professonals aspired to give attention to health education in their future work. Exemplary role recognition was weakly positively related to health education in the desired situation for schoolteachers and general practitioners, but not for community nurses.

Discriminant analysis showed that differences between the three professional groups were primarily determined by actual involvement in health education, secondly by exemplary role recognition and thirdly by health behavior. 


\subsection{Limitations of the study}

The study was carried out among relatively small samples of key health protessionals. Response rates were acceptable, but lower than optimal, especially among general practitioners. This was due to an overload of investigations going on in this profession at the time. The relatively low degree of consistency concerning personal health behavior and health educational aspects of professional practice, surely is a part of the reality, but may indeed be caused partially by the nature of post hoc measurement and the self reporting of health behavior. No social desirability rates were available to control here. The instruments used to measure health education in current and future practice had highly internal reliabilities, but stability overtime is questionable yet. This implies that the results regarding health education in the actual and in the future worksetting are clearly one shot results. The content validity of the instruments should be enhanced by expert judgements; the psychometric characteristics could be ameliorated by replications.

Apart from the global hypothesis of the desirability of consistency with regard to health norms applying to personal behavior and professional performance, no theoretical framework was used to organize the study. This "trawler's net" approach certainly has proven to be valuable to help the Netherlands to look into its "health mirror". Because baseline data are available now, more specific hypotheses can be formulated as stepping stones towards a theory of health behavior.

The development of a longitudinal perspective, however, is a prerequisite to the development of such a theory on health behavior. Within the limits of the survey-data reported here, only associations can be described. The explanation of etiology of health behavior is only possible through a panel design.

The study was not focussing on health professionals" effectiveness. In follow-up studies effectiveness e.g. of physician"s stop-smoking advice, of teachers' health education curriculum implementation efforts, or nurses' efficacy in supporting selficare capabilities in patients, should be addressed.

Another limitation of the study is given by the extent to which health education was developed in the three professions analyzed by 1983. As was described in chapter 2 . health education is subject to rapid changes, at a different pace in the three professions. Quite naturally, these influences were out of the control of the researcher.

\subsection{Implications}

In the next sections, some implications of the investigation reported here above for methods of research, for theory development, for health policy and professional preparation will be mentioned.

\subsubsection{Methods}

The experiences concerning the measurement of health education suggest that in the actual situation it is partly influenced by the degree of sensibilization and conceptualization, achieved in the performing professional group, partly by the way health education delivery is organized. Future research should apply both general 
Anstruments as our HEA and HEO-1tsts as well as observational techniques, whe studes otc. to increase validy and rolablity. The resuls concoming heath behavior show that is possible to measure healh bohavio comprehemsively ush we Rasch-scaing 1echnique. Replications should nclude larger domains of heatu related behaviors to extend he range of the health behavior scale, and to allow for population-determined tam-selection, as opposed to expart-detemined selection. Depending upon the broadening of the scope of the HBS, the instrument measuring exemplary role recogntion should be adapted, according to the health behavioral items chosen.

\subsubsection{Theory}

Hoath is a muthtaceted notion. It is not an analytical constud. The study of healh aducalion will continue to require a multidisciplinary ettort.

Heath education is not an analytical concept but as was delned by Rouwenhorst (1977) a lunction of some sectors in sociely. especially health care and education. On the grassroots level healh aducation is pat of the individual protessional's taste or of an organization's mission. The roles and lunctions health care providers and techers are expected to will should be further delneated. I accepted in the protessions and in the society, the extent to which these roles are pertormed is measurable, as long as they are well operationalized. The range of lields in which health education is applied is large: hospitals, nursing homes, heath centers, but also schools, sports facilties, tolevision, networks, kactories and offices. Diterent field seltings imply health education is cartied out as a part of variety of roles. The lunher delineation of healh oducation in these roles should be a systematic process; theory may be helphut there, but basically this process is a prolessional and a societal issue and not primarlily a scientific concern.

Heath behavior on the other hand is not a directy observable behavior but a latent variable, a theoretical construct that seems to make some sense. a valid and reliable way. It can help to understand some of the associations in human healh-directed and related behavior. Although the criteria set to what is heathy and what is considered to be unheathy are very rational, theoretical models restricting itselt to reasoned action alone are omitting crucial factors, as much of health behavior is codetermined by vile addiction, subtile publichy irrational trends and fashions, impersonal laws and regulations, etc.

The contribution of our analysis to the discussion on the nature of health behavior lles in the specification and quantifled underpinning of a unidimensional variable, hierarchically integrating the health behaviors according to difficulty, on the basis of the Rasch model.

The predictive value of this variable for future health behavior of a given population or for the future health status of this population cannot be established within the framework of our transversal design. There are indications that, if one would want to optimalize HBS as a predictor of health behavior, weighing health behaviors according to perceived seriousness as a threat to personal health would contribute. If one would want to optimalize HBS as a predictor of future health status l.e. of morbidity/mortality patterns. weighing single health behaviors according to their relative risk will enhance predictive validity. Predictive power would be enhanced also, if $\mathrm{HBS}$ would be used in a design based on Green's PRECEDE-model (Mullen, Hersey \& Iverson, 1986). 
Our findings regarding HBS show the "cascades" in key health professionals' selfreported health behavior. Earlier research had shown that sufficient coherence existed in either relevant dimensions of health behavior, or in the whole of health behavior. However, in the latter case, major health practices had to be removed (e.g. smoking). Our findings support the theory of the existence of a unitary health behavioral concept including major health practices.

Exemplary role is a notion frequently used in convivial conversation; in the framework of Festinger's theory of cognitive dissonance, exemplary role has a potential as an analytical tool not yet used as much as it would deserve. Though not used as a core concept in Bandura's theory of social learning, this approach with its focus on modeling. has already proven to be successful. The hypothesis of the existence of an exemplary role logically follows from the theory of modeling, in general. The exemplary role can be considered as a specification towards the field of health education, of the modeling theory. The evidence provided in this study shows that the existence of the exemplary role is accepted by limited numbers of key health professionals. It illustrates that more empirical support is needed to prove the effectiveness of the exemplary role in health education, in health care settings and in the school system. Application of social learning theory to further research into the effectivity of exemplary role behavior seems promising.

Various variables, such as locus of control, health image, role expectation, socioeconomic status in addition to personal and contextual characteristics can determine health behavior and health attitudes. Integration of disciplines, currently being seen in the development of training programs in schools of public health in various parts of the world, as well as in the development of health promotion policies, is not an academic objective per se. In future research it is recommendable to carefully coordinate efforts stemming from the disciplines involved to optimally contribute to solve current health problems instead of aiming at integration at theoretical and practical research levels.

\subsubsection{Pollcy}

In a realistic health promotion palicy all potentially effective instruments should be considered. The roles key health professionals can play may have been exaggerated in the past, recent policy underestimates them, reducing the discussion with them to organizational and budgettary issues, or to ideological debates without either organizational or budgettary consequences. In the Netherlands, for the first time, first line health care as well as the school system have gotten (some) offical tasks in the area of health education. This study has shown that there are important subgroups to be distinguished within the key health professionals groups: there are sizeable groups of key health professionals who act convincingly and consistently in personal and professional life, when it comes to their own and their clients' health. On the other hand, there are sizeable groups as yet not committed, who aspire to get involved in health education especially among general practitioners. In the year of cancer prevention, nobody can blame the gouvernment not to consider smoking physicians in their strategy. But it should consider those committed and those willing to develop their skills beneficial for primary prevention. 
It should consider also committed nurses and teachers, who on a day-to-day basis reach out into virtualy all corners in society to groups sensitive for health messages. By supporting community nurses, general practitioners and schoolteachers through growth of the personnel in their organizations, through mandatory continued education in health promotion and disease prevention, a health promotion policy could be considerably strengthened. At international and national levels, intersectoral cooperation for health promotion is needed and should be stimulated; it can only materialize at the local level. Together with colleagues in social services, in family aid programs, nurses, teachers and general practitioners should be enabled to fulfil their tasks optimally.

Health education be it in the framework of a health promotion policy must enter a poverty cycle, when resources are continued to be put into highly specialized care for the few, instead of into primary care for the many (fig. 1). Due to this circumstance, causing overload, teaching, nursing and especially general practice should be considered as growingly unhealthy activities for considerable proportions of these professionals. Key health professionals then would not only be suboptimal health care providers, but also are a great risk to harm their own health.

\section{Fig. 1: Health education cycle of poverty}

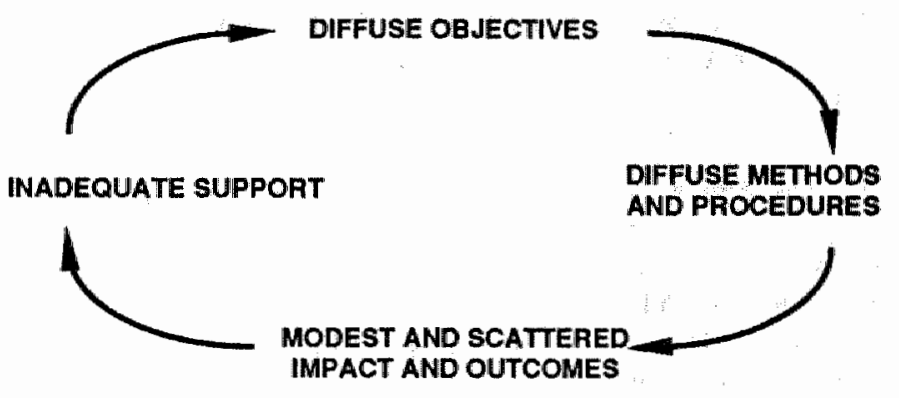

Source: Green, Kreuter, Deøds \& Partridge, 1980.

\subsubsection{Professional preparation}

In the professional preparation of teachers, nurses and general practitioners, more attention should be paid to personal health behavior, to health conceptions as $\infty$ determined by personal life style choices and to risks involved in practising these professions. Further research in this area should include health surveys in medical and nursing schools, and teacher training colleges, as well as curriculum development in the area of personal health management for key health professionals. Through careful study of the effectivity of health education carried out by teachers, nurses and physicians, this poverty cycle can be broken. Recently, a systematic effort of the Dutch National Center for Health Education has lead to the publication of a new review of the effectiveness of health education in all its tields of application (Jonkers, Liedekerken, De Haes, Kok \& Saan, 1988). Also, it seems useful to monitor trends in health behaviors in health 
professional groups through, for example, intemational coordination and standardization of surveys on smoking, as this is done already among medical students. Support can be provided also to nurses, teachers and general practitioners by providing continued education in health education, $0 . \mathrm{g}$. developed at the National Center for Health Education and implemented regionally through the respective professional organization. it has not been proven that smoking physicians are worse health care providers. Neventheless ${ }_{n}$ in the light of the indications of the impact of smoking key health professionals on the public report in this study, and also, in the light of the growing surplus of physicians on the labour market, the question whether smoking should be used as an admission-criterion for training programs, has to be considered.

\subsection{Further research}

In research into health education as delivered through key health professionals i.e. teachers, nurses and general practitioners, it is recommended that the focus should be on perception of and on time spient on health education, thus combining self-report and observation. Moreover, it is recommended to focus on applicability of health education methods in teaching, nursing and general medical practice, and on assessment of their effectiveness. Further clarification of key health protessional's role with regard to health education can be achieved through investigation of rolle expectations, performance and outcomes. Given the collaborative nature of health education future research should take into account the networking of key health professionals with other sectors, especially lay health organizations and local health educators.

In future research into health behavior, it is recommended to develop a broad range Health Behavior Scale, satisfying epidemiological and psychometrical characteristics. Lay-determined health behavioral items should be taken into account. It is recommended to replicate surveys on health behavior among specific professional groups, especially health professionals in order to get a clear view of what maximally informed individuals are willing and able to do for their health. Only additional panel studies can provide insights in secular trends in health behavior. In order to enhance the reliabillty of the measurement of health behavior, it is recommended to insert observations in the study design, to check the self-reporting of health behavior, and to carry out fysiological controls, for example concerning the smoking habit. Concerning the exemplary role it is recommended that the performance of this role be analyzed in relation to the targetgroups of the respective professionals and to the general public. Conditions for officaclous role performance then can be specified. In future applications, the measurement of EXR should be adapted to the broader range of health behavioral items referred to here above. 
Chapter 10. General discussion; concluding remarks

\section{References}

Green, L.W., Kreuter, M.W., Deeds, S.G., Partridge, K.B., 1980. Health Education Planning: a diagnostic approach. Mayfield: Palo Alto.

Jonkers, R., Liedekerken, P.C., De Haes, W.F.M., Kok, G.J., Saan, H., 1988. Effectiviteit van GVO. Uitgeverij Gezondheidlsbevordering. Rijswijk. (Effectiveness of thealth education).

Mullen, P., Hersey J.C., Iverson, D.C., 1987. Health behavior models compared. Social Science and Medicine, 24, 11, 973-981. 


\section{Summary}

This study focuses on three professional groups elementary school teachers. community nurses and general practitioners. Their health behaviors, the way they perceive health educational aspects of their work and their perception of their exemplary role are examined.

The study starts with a review of the literature pertaining to health education (chapter 2). health behavior (chapter 3) and the exemplary role of the three key health professionals (chapter 4). Health education definitions have as a common core: (1) the relationship between health and behavior; (2) the element of personal choice among a range of behavioral options; (3) the importance of participation by lay people and lastly the systematic planning for change and its evaluation. Long before 1985, when in the Netherlands the new law on elementary education became effective, systematic efforts to develop and implement school health education were made in Amsterdam and in Nijmegen. Health education had always been part and parcel of Dutch community nursing. Nowadays, the National Cross Union develops new policies strongly investing in local health education through networking, among professionals and with the community. Among general practitioners, the views on health education are more diverging. Role clarification was attempted by professional unions. The review of the literature presented in chapter 3 shows that health behaviors and their interrelationships have been analysed along three different approaches: the atomistic approach, the additivity approach and the scaling approach. In the first line of thinking, health behaviors are considered to independent; in the second a synergistic effect of a number of health behaviors is found and expressed in a health behavior index. In the third line of thinking, a scale is constructed, representing in an interval variable, the domain of health behavior delineated on the basis of psychometric criteria.

Most of the research into health behavior, carried out among doctors, nurses and teachers, focuses on single health behaviors. In many countries, doctors have had the lead in smoking reduction. Also, this professional group has relatively frequently problems with alcohol consumption and some other life style aspects, as have nurses, albeit to a lesser extent.

In chapter 4 , it is stated that teachers, nurses and doctors can be considered as key health professionals; meaning that their personal health practices can be assumed to influence on changes in the general public's health behavior. Theories of social learning and modeling help to understand the phenomenon of the exemplary role. However, evidence on the effectiveness of exemplary behavior is very scarce. Nevertheless, among all three professional groups, the exemplary role was found to be stressed at many occasions. Evidence of its large acceptance by the professionals was reported with regard to smoking. In the public"s view, the physician is more influential than teachers and nurses.

In chapter 5, the organization of the survey carried out among samples of Dutch elementary schoolteachers, community nurses and general practitioners is described.

In chapters 6-9 results are presiented. The study has resulted in a wealth of data on health conceptions and behaviors and health educational aspects of the work of schoolteachers, community nurses and general practitioners. An analysis using the four core variables is presented. These four core variables were: the perception of health 
educational aspects in the actual and desired work situation of the three professional groups, their health behavior and their eventual exemplary role. The health educational aspects of the work have been measured by a set of ten (aggregated) competencies. Respondents rated their importance in their actual work setting on a lour-point scale, and the extent to which a given health professional would want to give less equal or more attention to any health educational competency on a five-point scale. Health behavior was measured by a twelve-item Health Behavior Scale (HBS) comprising items concerning coffeo-, alcohol-, tobacco- and sugar consumption, dental hygïene and check-up frequency, on weight for height, sleep duration, seatbelt use and manual hygiene. Exemplary role recognition (EXR) was measured by a silx-item list containing three general lifestyle statements and three others pertaining to alcohol-, drugs- and tobacco-use.

As is reported in chapter 6 , the involvement of general practitioners in health education in their actual practice was much less than that of community nurses and elementary schoolteachers. A lack of coherence in health educational efforts by these professional groups showed. Moreover, none of them fulfils or aspires a coordinating role.

In chapter 7 the results concerning the health behavior of the professional groups is presented. Compared with the Dutch population at large, key health professionals more frequently choose healthy alternatives with regard to breakfasting, coffee consumption and dental hygiene. Surprisingly, they are snacking more sweets in between meals than the population at large reports doing. Less community nurses, however, use sugar in their coffee. While considerably fewer schoolteachers and community nurses are current smokers, there are more current smokers in general practitioners than in the male population. While nurses less trequently immoderately consume alcohol, schoolteachers and general practitioners do so more frequently than the population in Holland.

Health behaviors appeared to be less prevalent in general practitioners than in community nurses and schoolteachers, especially non-smoking, moderate use of alcohol and seatbelt use. Using a comprehensive Health Behavior Scale to measure health behavior, it appeared that community nurses had the most healthy lifestyle, followed closely by schoolteachers. In chapter $\mathbf{8}$ it is shown, that exemplary role recognition differed significantly in key health professionals, schoolteachers recognizing an exemplary role to the largest extent, followed by community nurses and finally by general practitioners.

In chapter 9, the relationships between the four core variables are examined. For schoolteachers and community nurses the extent to which one practises health education in the actual work setting appeared to be positively related to the extent to which these professions wanted to act on health education in their future professional practice; not so, for general practitioners, however.

For schoolteachers and community nurses, health behavior was not related to health education in their current work setting; this was onlly the case for general practitioners, albeit largely consistently negative. Health behavior appeared to be related to the extent to which an eventual exemplary role is recognized for general practitioners and community nurses, but not for schoolteachers. Current health behavior appeared to be unrelated to the extent to which professionals aspired to give attention to health education in their future work. Exemplary role recognition was weakly positively related to health education in the desired situation for school teachers and general practitioners, 
but not for community nurses.

Discriminant analysis showed that differences between the three prolessional groups were primarily determined by actual involvement in health education, secondly by exemplary role recognition and thirdly by health behavior.

In chapter 10 the results are discussed. Implications for measurement, theory policy and professional preparation, as well as suggestions for further research are listed. 


\section{Resumo}

Tiu laboro fokusigas tri grupojn: bazlernejaj instruistoj, komunuma flegistinoj kaj generalaj kuracistoj. lliaj sankonduto, llia sento pri la sanedukaj aspektoj de la laboro kaj ilia sinteno pri la eksemplula rolo, estas ekzamenataj.

La raporto komencigas je superrigarco de la literaturo pril sanedukado (Capitro 2) sankonduto (Capitro 3) kaj la ekziemplula rolo de la tri ŝlosilrolantaj samprofesiulọ (Capitro 4). Sanedukaj difinoj kiel komuna kerno havas: (1) la rilato inter sano kaj konduto; (2) la elemento de persona elekto inter skalo de konduteblecoj; (3) la graveco de partopreno de neprofesiuloj kaj la sistema planado celante ŝanĝojn kaj ties evaluadon. Jam delonge antaŭ 1985, kiam en Nederlando la nova lego pri la baza edukado efektivigîs, sistemaj klopodoj por evoluigi kaj disvastigi tralernejan sanedukadon disvolvighis en Amsterdam kaj en Nijmegen. San edukado ciam apartiĝis al la nederlanda komunuma flegado. Hodiat, la Nacia Kruc-Organizo kreas novajn strategiojn, investante en loka sanedukado tra retigado, inter sanprofesiuloj kaj kun la komunumo. En la grupo de familiaj kuracistoj, la opinioj pri sanedukado estas pli diversaj. Rolklarigo estis alstrebita far de la profesiaj organizajoj. La superrigardo de la literaturo, prezentita en capitro 3 montras ke sankondutoj kaj ties interrilatoj estis analizataj laŭ tri malsamaj vojoj: la atomisma, la aldoniga kaj la skaliga vojoj. En la unua pensmaniero, sankondutoj estas konsiderataj kiel sendependaj kondutoj; en da dua pensmaniero, aldoniga efiko de kvanto de sankondutoj estas trovata kaj esprimata on sankonduta indekso. En la tria pensmaniero, skalon oni konstruas estante varianto intervala, limigante la sankondutaron surbaze de kriterioj psikometrikaj.

Plejgrandparte, la esploroj en sankonduto farataj en la grupoj de kuracistoj, de flegistoj kaj de instruistoj, fokusighas sur unusola sankonduto. En pluraj landoj, kuracistoj antaŭiĝis on la kampo de la kontraưfumado evoluo. Samtempe, ĉi-tiu profesia grupo havis relative oftajn problemojn konserne alkoholkonsumo kaj pluraj aliaj vivstilaspekoj, same kiel flegistoj, kvankam malpli grandskale.

En capitro 4, estas montrata ke instruistoj flegistoj kaj kuracistoj povas esti konsiderataj kiel ŝlosilaj sanprofesiuloj; tiu volas diri ke per ilies personaj sankondutoj ili influigas la ŝanĝojn en la sankonduto de la generala publiko. Teoriol de sociala lernado kaj modeligo helpas en la kompreno de la fenomeno de la ekzemplula rolo. La pruvoj por la efikeco de ekzemplula konduto estas ege maloftaj: Malgraŭ tio, en ciluj tri protesiaj grupoj, oni regula substrekis la gravecon de la ekzemplula rolo. Pruvol de larĝskala rekono far sanprofesiuoloj estis raportataj konserne fumado. En la okuloj de la publiko, la kuracisto havas pli grandan influencon al la instruistoj kaj la flegistinoj.

En çapitro 5, la organizado de la enketo farata inter bazlernejaj instruistoj komunuma flegistoj kaj familiaj kuracistoj estas priskribata.

En la çapitro 6 gis 9 , la resultoj estas prezentataj. La priesplorado resultis en granda riçeco de donitajoj konserne la sankonseptoj kaj sankondutoj kaj konserne la sanedukaj aspektoj de la laboro de bazlernejaj instruisto], komunumaj flegistinol kaj familiaj kuracistoj. Analizo, uzante la kvar kernvariantoj estas prezentata. Ći-tiu kvar kernvariantoj estis: la percepto de sanedukaj aspektoj en la aktuala kaj dezirata labor situacioj de la tri profesiaj grupoj, ilies sankonduto kaj ilies eventuala ekzemplula rolo. La sanedukaj aspektoj de la laboro oni mezuris per listo de dek (grupataj) kapablecoj. Respondintoj indikis la gravecon en la aktuala laborsituacio je kvarpunkta skalo, kaj la 
mezuron laǔ kiu ili ŝatus doni malplian egalan au plian atenton al iu sanedukada kapableco, je kvinpunkta skalo. Sankonduto estis mezurata helpe de 12-era San Konduta Skalo (HBS (angle)) enhavante eldiroj konserne la konsumado de kalo, de alcoholajoj, de tabakajo kaj de sukero, de la higieno denta kaj ties kontrolo duonjara, de la Quetelet-indekso, la dormlongeco, la uzo de sekurigiloj en la aŭto kaj la manhigieno.

Kiel raportite en çapitro 6 , la enkondukigho de la familiaj kuracistoj en sanedukado en ilies aktualaj praktikoj estis multe pli malgrandskala ol de komunumaj flegistinoj au bazlernejaj instruistoj. Montrigis malrilateco en la sanedukaj strebadoj far de la profesial grupoj. Plue, neniu el ill plenumas au aspiras kunordigan rolon.

En çapitro 7, la rezultoj konserne la sankonduto de la protesiaj grupoj estas prezantataj. Kompare al la nederlanda populacio generale, la ŝlosil-rolantuloj en la kampo de porsana zorgo, pliofte elektas sanigajn konduteblecojn rilate la matenmanĝo, la konsumado de kafo kaj denthigieno. Surprize, ill mangas pli da intermanĝaj dolçajoj ol la populacio. Aliflanke malpli da flegistoj uzas sukeron en ilia kafo. Unuflanke montrigis ke en la grupoj de bazlernejaj instruistoj kaj komunumaj flegistoj ekzistas klare malpli da nunaj fumantoj, aliflanke ekzistas pli da nunaj fumantoj en la grupo de familiaj kuracistoj ol en la vira populacio. Dume flegistoj malpli ofte konsumegas alkoholajojn, instruistoj kaj kuracistoj faras tion pliofte ol la nederlanda populacio.

Sanaj kondutmanieroj montrigis pli malottaj en la grupo de kuracistoj ol en flegistoj kaj instruistoj, specife nefumado, ŝpara alcoholkonsumo kaj sekurigiluzo. Uzante la sankondutskalo HBS por mezuri la sankonduton, montrîgis ke flegistoj vivis laŭ la plejsaniga vivstilo, sekvita deproksime far la instruistoj.

En çapitro 8, montrigas ke la rekono de la ekzemplula rolo malsimilas klare inter la grupoj profesiaj, instruistoj rekonante la ekzemplulan rolon plejlarge sekvita far la flegistoj kaj laste far la familiaj kuracistoj.

En la ĉapitro 9, la rilatoj inter kvar kernvariantoj estas priesplorataj. En la kazoj de la instruistoj kaj flegistoj la largeco de la saneduka praktiko aktuala estis positive rilatigita al la largeco de la deziro praktiki sanedukadan en ilia profesia estonteco; tio ne aplikis en la kazo de la kuracistoj.

En la kazoj de la instruistoj kaj flegistoj la sankonduto ne rilatis al saneduka aktiveco en aktuala laborsituacio; tiu nur trafis por la grupo de la kuracistoj, kvankam plejparte konsekvence negative: Montrigis ke sankonduto rilatis al la mezuro je kiu profesiulo rekonis eventualan ekzemplulan rolon en la kazo de kuracistoj kaj flegistinoj sed ne en la kazo de la instruistoj. Montrigîs ke aktuala sankonduto ne rilatis al la mezuro je kiu profesiuloj aspiris doni atenton al sanedukado en ila futura laboro. La rekono de la ekzemplula rolo rilatis malforte positive al sanedukado en la futura situacio por instruistoj kaj kuracistoj, sed ne en la kazo de flegistoj.

Diferenciga analizo montrigis, ke la diferencoj inter la tri profesiaj grupoj estis unue determinataj de akuala en kondukigho en sanedukado, diferencoj inter la tri profesiaj grupol estis unue determinatal de akuala enkondukiĝ́o en sanedukado, due de la rekono de la ekzemplula rolo, kaj trie de sankonduto.

En Capitro 10 oni pridiskutas la rezultojn. Konsekvencoj por la mezurado, por la teorio, por la gubernigado, por la profesia preparado, same kiel por la esploro estonteca, estas listigataj. 


\section{Samenvatting}

Dit onderzoek is gericht op drie beroepsgroepen: basisschool-leer krachten, wijkverpleegkundigen en huisartsen. Hun gezondheidsgedrag, de wijze waarop zij gezondheidsvoorlichting en -opvoedingsaspekten van hun werk zien, alsmede hun perceptie van de voorbeeldrol, worden onderzocht.

Het onderzoeksverslag vangt aan met een overzicht van de literatuur met betrekking tot gezondheidsvoorlichting en -opvoeding (hoofdstuk 2), gezondheidsgedrag (hoofdstuk 3) en de voorbeeldrol van de drie typen gezondheidswerkers (hoofdstuk 4). Definities van gezondheids voorlichting en -opvoeding hebben als gemeenschappelijke kern: (1) de relatie tussen gezondheid en gedrag; (2) het element van persoonlijke keuze tussen een reeks van gedragingen; (3) het belang dat gehecht wordt aan participatie door leken en tenslotte (4) de systematisch geplande verandering on de evaluatie ervan.

Reeds lang voor 1985, toen in Nederland de nieuwe wet op het basisonderwijs van kracht werd, werd gezondheidsvoorlichting en -opvoeding op school systematisch opgezet en uitgevoerd in projekten in Amsterdam en vanuit Nijmegen (Hoogveld Instituut). Gezondheids voorlichting en -opvoeding was altijd al geintegreerd geweest in de wijkverpleging in Nederland. Tegenwoordig ontwikkelt de Natlonale Kruisvereniging nieuw beleid, waarbij lokale gezondheidsvoorlichting en -opvoeding door de opbouw van netwerken tussen gezondheidswerkers en de gemeenschap sterk wordt benadrukt. Onder huisartsen lopen de visies op gezondheidsvoorlichting en -opvoeding meer uiteen. Er werden pogingen tot rolverheldering gedaan door de beroepenorganisaties. Het literatuuroverzicht, gepresenteerd in hooldstuk 3 , laat zien dat gezondheidsgedragingen en hun onderlinge relaties langs drie verschillende lijnen werden geanalyseerd: de atomistische benadering, de additieve benadering en de schaalbenadering. In de eerste opvatting worden gezondheidsgedragingen als onathankelijk beschouwd; in de tweede wordt een synergistisch effekt van een aantal gezondheids gedragingen gekonstateerd en uitgedrukt in een index. In de derde opvatting wordt een schaal gekonstrueerd, waarop een interval variabele wordt gemeten; het domein van gezondheidsgedrag wordt afgebakend aan de hand van psychometrische kriteria.

Het meeste onderzoek van gezondheidsgedrag van artsen, verpleegkundigen en leerkrachten is gericht op losstaande gezondheidsgedragingen. In talijke landen hebben artsen een leidende rol in de afname van de rookgewoonten vervuld. Dok blijkt dat deze beroepsgroep relatief vaak problemen met alkoholgebruik en enige andere aspekten van de leefstijl heeft; dat geldt ook voor verpleegkundigen, zij het in mindere mate.

In hoofdstuk 4 wordt gesteld dat leerkrachten, verpleegkundigen en artsen als sleutelfiguren in de zorg voor gezondheid kunnen worden beschouwd. Dat houdt in, dat er reden is om aan te nemen dat hun persoonlijke gezondheidsgedragingen het gezondheidsgedrag van de algemene bevolking beïnvloeden. Theorieën inzake social learning en modeling dragen bij tot het begrijpen van het verschijnsel van de voorbeeldrol. Onderzoeksresultaten, die de effektiviteit van de voorbeeldrol aantonen, zijn echter zeer schaars. Niettemin werd vastgesteld, dat de voorbeeldrol in alle drie de beroepsgroepen veelvuldig werd benadrukt. Met betrekking tot de rookgewoonte is een aanzienlijke aanvaarding van de voorbeeldrol door gezondheidswerkers, aangetoond. In de opvatting van het publiek heeft de arts meer invloed dan leerkrachten of verpleegkundigen. 
In hoofdstuk 5 wordt de opzett en uiltvoering van de enquëte uítgevoerd onder streekproeven van basisschool-leerkrachten, wijkverpleegkundigen en huisartsen in Nederland, beschreven.

De resultaten van het onderzoek komen aan de orde in de hoofdstukken 6 tot en met 9. Het onderzoek heeft veel gegevens opgeleverd over gezondheidsopvattingen en gedragingen alsmede over gezondhelds voorlichting en -opvoedingsaspekten van het werk van leerkrachten, wijkverpleegkundigen en huisartsen. Een analyse, waarbij de vier kernvariabelen werden gebruikt, wordt gepresenteerd. Deze vier kerrvariabelen waren: de perceptie van gezondheidsvoorlichting en -opvoedingsaspekten in de aktuelle en gewenste werksituatie van de drie beroepsgroepen, hun gezondheidsgedrag en hun eventuele voorbeeldrol. De gezondheidsvoorlichting en -opvoedingsaspekten wan het werk werden gemeten met behulp van een lifst van tien (groepen) kompetenties. De respondenten gaven het belang ervan in hun huidige werksituatie aan op een vierpuntsschaal; de mate waarin een gezondheidswerker meer, gelijke, of minder aandacht zou willen geven aan enige gezondheids voorlichting en -opvoedingkompetentie, op een vilfpuntsschaal. Gezondheidsgedrag werd gemeten met behulp van een uit twaalf items bestaande gezondheidsgedrag-schaal (HBS), omvattende de onderwerpen: kotfie-, alkohol-, tabak- en suikergebruik, mondgezondheid en -kontrole, de Quetelet-index, slaapduur, gebruik van veiligheids gordels en frekwentie van handen wassen. De onderkenning van de voorbeeldrol (EXR) werd gemeten door ean uit zes items bestaande lijst, omvattend drie uitspraken met betrekking tot leafstij in het algemeen, en drie andere, betrekking hebbend op alkohol-, drugs-en tabakgebruik. In hoofdstuk 6 wordt gerapporteerd dat de betrokkenheid van huisartsen in gezondheidsvoorlichting en -opvoeding in hun huidige werk veel geringer was dan die van wijkverpleegkundigen en leerkrachten in de basisschool. Er kwam een gebrek aan samenhang in de gezondheids voorlichting en -opvoeding-aktiviteiten van deze beroepsgroepen aan het licht. Bovendien vervult geen van deze groepen een koördinerende rol, noch wordt deze geambiëerd.

In hoofdstuk 7 worden de resultaten met betrekking tot het gezondheidsgedrag van de beroepsgroepen gepresenteerd. Vergeleken met de Nederlandse algemene bevolking, kiezen sleutelfiguren in de zorg voor gezondheid frekwenter voor gezonde alternatieven inzake ontbijten, koffie drinken en mondhygiëne. Verrassend is dat de sleutelfiguren meer zoete tussendoortjes zeggen te gebruiken dan de algemene bevolking zegt te doen. Minder wijkverpleegkundigen gebruiken suiker in hun koffie. Terwijl er onder leerkrachten en wijkverpleegkundigen aanzlenllik minder huidige rokers gevonden worden, blijken or meer huidige rokers onder huilsartsen te zijn dan in de maninelijke bevolking. Terwijl wijkverpleegkundigen minder vaak overmatig alkoholhoudende dranken konsumeren, doen leerkrachten en huisartsen dat vaker dan de algemene bevolking in Noderland.

Gezond gedrag komt minder voor onder huisartsen dan onder wijkverpleegkundigen en leerkrachten, met name niet-roken, matig alkoholgebruik en gebruik van veiligheidsgordels. Gemeten met behulp van de samengestelde HBS blijkt de leefstill van wijkverpleegkundigen het gezondst te zijn, direkt gevolgd door de leerkrachten.

In hooldstuk 8 wordt aangetoond dat de mate van onderkenning van de voorbeeldrol signifikant verschilt tussen de beroepsgroepen, waarbij leerkrachten het hoogst skoren, gevolgd door de wijkverpleegkundigen en tenslotte door de huisartsen. 
In hoofdstuk 9 worden de samenhangen tussen de vier kernvariabelen onderzocht. Voor wat betreft leerkrachten en wijkverpleegkundigen bleek de mate, waarin men gezondheidsvoorlichting en -opvoeding uitvoert in het huidige werk positief verband te vertonen met de mate, waarin de beroepsbeoefenaren aandacht aan gezondheidsvoorlichting en -opvoeding in hun toekomstige werk wensten te besteden; dit gold echter niet voor huisartsen.

Voor wat betreft leerkrachten en wijkverpleegkundigen was gezondheids gedrag niet gerelateerd aan gezondheidsvoorlichting en -opvoeding in hun huldige werk; dit was alleen het geval bij de huisartsen, hoewel het gevonden verband konsistent negatief was. Gezondheidsgedrag bleek gerelateerd aan de mate, waarin men een eventuele voorbeeldrol onderkent voor wat betreft huisartsen en wijkverpleegkundigen, maar niet voor leerkrachten. Huidig gezondheidsgedrag bleek geen verband te houden met de mate, waarin beroepsbeoefenaren aandacht wensten te geven aan gezondheidsvoorlichting en -opvoeding in hun toekomstig werk. Onderkenning van de voorbeeldrol was zwak positief verbonden met gezondheidsvoorlichting en -opvoeding in de gewenste situatie voor wat betreft leerkrachten en huisartsen, maar niet voor wijkverpleegkundigen.

Door middel van discriminant analyse werd aangetoond dat de verschillen tussen de drie beroepsgroepen primair bepaald werden door betrokkenheid bij gezondheidsvoorlichting en -opvoeding in het huidige werk, vervolgens door de mate, waarin men de voorbeeldrol onderkende, en pas in de derde plaats door gezondheidsgedrag.

In hoofdstuk 10 werden de resultaten besproken. Voorts worden implikaties voor de wijze van meten, voor theorie, voor beleid en voorbereiding op de beroepsuitoefening, zowel als voor verder onderzoek geformuleerd. 


\section{Curriculum vitae}

Hans Adriaanse was born in 1946 in Amsterdam, the Netherlands. After graduation from secondary school in 1967, he studied French at the Nutsseminarium of the University of Utrecht. From 1969 to 1973 he studied Pedagogy at the University of Amsterdam. From 1973 till 1976 he studied educational sciences at the University of Groningen. Atter a short commitment as a curriculum developer at the School of Nursing at Nijmegen, he was employed at the University of Limburg in October 1977. As a member of the Educational Research and Development Group, headed by professor Wijnand H.F.Wijnen, he participated in the preparatory work leading to the establishment of the Faculty of Health Sciences in 1980 . He has been on the faculty of the Department of Health Education (chairman Prof.Dr.Gerjo.J.Kok) since 1980. He has been the chairman of the Department of Health Education in 1980-1981 and of the Curriculum Planning Committee for the Health Education Program from 1979 till 1982, and again from 1987 on. 